RODRIGO RODRIGUES LEITE VIEIRA

\title{
A COMPETÊNCIA PARA A INSTITUIÇÃO DO ICMS NA EXTRAÇÃO DO PETRÓLEO
}

\author{
DISSERTAÇÃO DE MESTRADO
}

ORIENTADOR:

PROFESSOR DOUTOR PAULO DE BARROS CARVALHO

FACULDADE DE DIREITO DA UNIVERSIDADE DE SÃO PAULO

SÃO PAULO

2014 


\title{
RODRIGO RODRIGUES LEITE VIEIRA
}

\section{A COMPETÊNCIA PARA A INSTITUIÇÃO DO ICMS NA EXTRAÇÃO DO PETRÓLEO}

\begin{abstract}
Dissertação apresentada à banca examinadora da Universidade de São Paulo, como exigência parcial para a obtenção do título de Mestre em Direito, na área de concentração de Direito Econômico e Financeiro, sob a orientação do Professor Doutor Paulo de Barros Carvalho.
\end{abstract}

FACULDADE DE DIREITO DA UNIVERSIDADE DE SÃO PAULO

SÃO PAULO 
BANCA EXAMINADORA

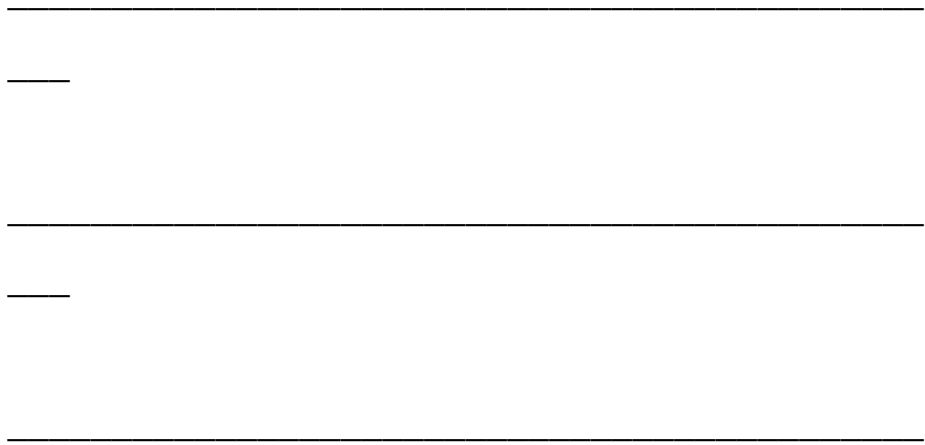


Dedico este trabalho

A minha esposa, Cíntia, flor da minha vida que perfuma o meu caminho, com amor $e$ carinho.

Aos meus amados pais, Haroldo e Maria Inez, a quem tenho eterna gratidão e admiração.

À memória do meu saudoso avô Tote. 


\section{AGRADECIMENTOS}

Agradeço, inicialmente, a Deus pela graça da vida.

Aos meus pais, Haroldo e Maria Inez, por tudo, pelo amor, carinho, exemplo de caráter e valiosos ensinamentos de vida.

A Cíntia, que desde o início compartilhou as alegrias e aflições deste trabalho, pelo incondicional amor e, sobretudo, pela compreensão pelos prolongados períodos de ausência.

A minha querida Tia Maria Leonor Leite Vieira, madrinha do coração, a quem tenho eterna gratidão por tudo que fez e faz na minha vida pessoal e profissional.

Ao Professor Paulo de Barros Carvalho, pela orientação e por ter me ensinado o caminho para aprender a ciência do Direito Tributário.

Ao Professor Robson Maia Lins, pela prontidão em me ajudar nos momentos cruciais deste trabalho.

A minha querida irmã, Ana Paula, ao pequeno Pedro Henrique, aos meus sogros, Vinício e Irani, e aos meus cunhados, Érico, Jéssica e Gabriel, que mesmo distantes me apoiaram nessa longa jornada.

Aos amigos Rodrigo França (Baiano), Bruno Baruel, Diogo Figueiredo (Didi), Carolina Massad e Rodrigo de Freitas, velhos companheiros. 


\section{RESUMO}

O objetivo deste trabalho é analisar a regra-matriz constitucional do ICMS mercantil e dos princípios que regem esse imposto, a fim de verificar se os Estados e o Distrito Federal detêm competência para a instituição do ICMS na extração do petróleo, a exemplo do que fez o Estado do Rio de Janeiro por meio da Lei no 4.117/03, conhecida como "Lei Noel".

Para tal desiderato, será investigado, inicialmente, o tratamento constitucional atribuído ao petróleo, e serão abordadas questões atinentes às atividades econômicas do monopólio da União sobre esse bem público, prescritas no artigo 177 da Carta Maior, e a sua flexibilização com o advento da Emenda Constitucional n ${ }^{\circ}$ 9/95.

Com supedâneo nas conclusões obtidas a partir da regra-matriz de incidência do ICMS mercantil e dos enunciados constitucionais relativos ao petróleo, serão analisados os os critérios componentes da regra-matriz de incidência construída a partir dos enunciados veiculados pela Lei $\mathrm{n}^{\circ} 4.117 / 03$ para que seja possível, dessa forma, verificar se o legislador ordinário estadual observou os limites para o exercício da competência ao instituir o ICMS na extração do petróleo.

Palavras-chave: Regra-Matriz de Incidência Tributária; ICMS; Monopólio; Petróleo; Lei $\mathrm{n}^{\circ} 4.117 / 03 ; \mathrm{ADIN} \mathrm{n}^{\circ} 3019$. 


\begin{abstract}
The purpose of this study is to analyze the ICMS constitutional matriz-rule of tax incidence and principles that govern such tax, in order to verify the capability of States to create this tax on oil extraction, as it did Rio de Janeiro through Law No. 4.117/03, known as "Lei Noel”.

This study will initially analyze constitutional rules regarding oil as well as aspects related to the economic activities of monopoly, prescribed in Article 177 of Federal Constitution and its flexibility with the advent of Constitutional Amendment No. 9, occurred in 1995.

Based on the conclusions obtained from the analysis of ICMS matriz-rule of tax incidence and constitutional rules concerning oil, we will investigate Law No. 4.117/03 in order to check if the Rio de Janeiro State respected the limits imposed by Federal Constitution to create ICMS on oil extraction.
\end{abstract}

Keywords: Matrix norm of tax incidence; ICMS; monopoly; oil; Law No. 4.117/03; ADIN $n^{\circ} 3019$. 


\section{SUMÁRIO}

INTRODUÇÃO 10

CAPÍTULO 1: CONCEITOS FUNDAMENTAIS 13

1.1. Fixação do objeto 13

1.2. Percurso da construção dos sentidos dos textos jurídicos 14

1.3. Norma jurídica em sentido amplo e em sentido estrito 17

1.4. Estrutura da norma jurídica 18

$\begin{array}{ll}\text { 1.4.1. } \mathrm{O} \text { antecedente normativo } & 19\end{array}$

1.4.2. O operador deôntico 20

1.4.3. O consequente normativo 20

1.5. Norma jurídica completa $\quad 21$

1.6. Espécies normativas 22

1.7. A regra-matriz de incidência tributária 24

1.7.1. A hipótese tributária e os seus critérios 25

1.7.1.1. Critério material 25

1.7.1.2. Critério espacial 26

1.7.1.3. Critério temporal 28

1.7.2. O consequente e os seus critérios 28

1.7.2.1. Critério pessoal $\quad 29$

1.7.2.2. Critério quantitativo 30

1.8. Fontes do Direito 31

1.8.1 A enunciação como fonte de Direito e o seu produto (enunciado) 32

1.9. Competência tributária 36

1.9.1. Conceito 36

1.9.2. Estrutura da norma de competência $\quad 37$

1.9.3. Limites formais para o exercício da competência 39

1.9.4. Limites materiais para o exercício da competência 42

1.9.5. Características da competência tributária 44

1.10. A lei complementar e o papel das normas gerais em matéria tributária 47

CAPÍTULO II: O ICMS MERCANTIL $\quad 50$

2.1. Perfil constitucional do ICMS 50

2.2. Regra-matriz constitucional do ICMS mercantil $\quad 55$

2.2.1. Critério material do ICMS $\quad 55$

2.2.2. Critério temporal do ICMS $\quad 59$

2.2.3. Critério espacial do ICMS 60

2.2.4. Critério pessoal do ICMS 62

2.2.4.1. Sujeitos ativo e passivo (contribuintes) 62 
2.2.5. Critério quantitativo do ICMS

CAPÍTULO III: PETRÓLEO, RECURSOS MINERAIS E SOBERANIA 66

3.1. Evolução dos regimes de mineração no Brasil 66

3.1.1. Regime regalista do Período Colonial 66

3.1.2. Regime dominial durante o Brasil Império $\quad 67$

3.1.3. A Constituição Republicana de 1891 e o regime de acessão 68

3.1.4. A Constituição de 1934 e o regime de concessão 68

3.1.5. O Estado Novo e a Constituição de $1937 \quad 69$

3.1.6. As Constituições de 1946 e 1967 e a manutenção do sistema previsto pela Constituição de $1937 \quad 70$

3.1.7. A Constituição Federal de 1988 e o regime jurídico atual da mineração 70

3.2. Do conceito de monopólio $\quad 73$

3.2.1. A criação da Petrobras e o monopólio do petróleo 74

3.2.2. Monopólio previsto na Constituição de 1988 até o advento da Emenda

Constitucional n ${ }^{\circ} 9 / 95 \quad 75$

3.2.3. Emenda Constitucional n ${ }^{\circ}$ 9/95 e a "flexibilização" do monopólio do petróleo 77

3.2.4. A Lei $\mathrm{n}^{\circ} 9478 / 97$ e o fim do exercício do monopólio exclusivo pela Petrobras 79

3.3. As compensações financeiras e as participações governamentais previstas na Lei $n^{0}$ 9478/97

3.3.1. Natureza jurídica das compensações financeiras $\quad 82$

3.3.2. Espécies de participações governamentais 86

3.3.2.1. Bônus de assinatura 86

3.3.2.2. Royalties $\quad 87$

3.3.2.2.1. Distribuição dos royalties

3. 3.2.3. Participação especial 90

3.3.2.4. Pagamento pela retenção da área ou taxa de ocupação 91

3.4. Dos demais regimes regulatórios das atividades de exploração e produção de petróleo

e gás natural $\quad 92$

CAPÍTULO IV: A REGRA-MATRIZ DO ICMS NA EXTRAÇÃO DO PETRÓLEO 94

4.1. A Lei do Estado do Rio de Janeiro n 4.117/03 94

4.2. Da análise do critério material: realizar operações com extração de petróleo 96

4.2.1. Petróleo como bem público da União 98

4.2.2. Extração como processo de produção do petróleo 104

4.2.3. Da natureza jurídica do contrato de concessão de exploração de petróleo $\quad 108$

4.2.4. Objeto do contrato de concessão do petróleo 111

4.2.5. Da conferência do petróleo ao concessionário após a sua extração 114

4.3. Critério temporal: passagem do petróleo pelos postos de medição de produção 116 
4.4. Critério espacial do ICMS e as jazidas de petróleo

4.4.1. Vigência territorial do ICMS e extraterritorialidade

4.4.2 Competência exclusiva da União para dispor sobre as águas marítimas

4.4.2.1. Mar territorial

4.4.2.2. Zona econômica exclusiva e plataforma continental

4.4.2.3 A interpretação do artigo $20, \S 1^{\circ}$, da Constituição Federal

4.5. Critério quantitativo

4.6. Critério pessoal

4.6.1. União e a imunidade recíproca

4.6.2. O extrator como contribuinte

4.7. O princípio da não cumulatividade do ICMS e a extração do petróleo

4.7.1. Princípios constitucionais

4.7.2. Breves considerações sobre o princípio da não cumulatividade

4.7.4. Do aproveitamento do crédito de ICMS no Estado de destino se devido o ICMS na extração do petróleo

CONCLUSÕES 


\section{INTRODUÇÃO}

O artigo 176 da Constituição Federal de 1988 estabelece que "as jazidas, em lavra ou não, e demais recursos minerais e os potenciais de energia hidráulica constituem propriedade distinta da do solo, para efeito de exploração ou aproveitamento, e pertencem à União, garantida ao concessionário a propriedade do produto da lavra".

No que tange especificamente ao petróleo, a redação original do artigo $177, \S 1^{\circ}$, da Constituição Federal de 1988 enumerava as atividades que eram monopólio da União (pesquisa e lavra das jazidas de petróleo e gás natural, refinação de petróleo, importação e exportação de produtos derivados de petróleo, transporte marítimo de petróleo bruto etc.), sendo-lhe vedado ceder ou conceder a exploração das jazidas.

Contudo, com o advento da Emenda Constitucional $n^{\circ}$ 9, de 1995, foi dada nova redação ao parágrafo $1^{\circ}$ do referido enunciado, flexibilizando, destarte, o monopólio da União, o que permitiu a contratação de empresas estatais ou privadas para o desenvolvimento das atividades ligadas à indústria petrolífera, desde que observadas as condições estabelecidas em lei.

Em conformidade com o dispositivo constitucional em apreço, sobreveio a Lei $\mathrm{n}^{\circ}$ 9.478/1997 ("Lei do Petróleo"), dispondo sobre a política energética nacional, as atividades relativas ao monopólio do petróleo, além da instituição do Conselho Nacional de Política Energética e da Agência Nacional do Petróleo.

$\mathrm{O}$ artigo 26 da lei em comento, em consonância com o artigo 176 da Carta Maior, estabeleceu que o concessionário tem a obrigação de explorar, por sua conta e risco e, em caso de êxito, produzir petróleo ou gás natural em determinado bloco, conferindo-lhe a propriedade desses bens, depois de extraídos.

Destarte, por uma questão de política energética, a Lei do Petróleo, visando incentivar os investimentos para o aumento da produção de petróleo no Brasil, garantiu que o petróleo explorado pertence ao concessionário.

Diante desse cenário, o Estado do Rio de Janeiro promulgou, em 30 de junho de 1993, a Lei $\mathrm{n}^{\circ} 4.117$, mais conhecida como Lei Noel, que alterou a Lei Estadual $\mathrm{n}^{\circ}$ $2.657 / 96$.

A referida lei estabelece que o "fato gerador" do Imposto sobre Circulação de Mercadorias e Serviços (ICMS) ocorre na extração do petróleo, quando a mercadoria passar pelos pontos de medição da produção. 
Tal Lei é objeto da Ação Direta de Inconstitucionalidade $n^{\circ} 3.019$, proposta pelo Procurador Geral da República, a qual não foi julgada pelo Supremo Tribunal Federal até o momento.

Na referida ação, o Governo do Estado do Rio de Janeiro sustenta que, no instante em que o petróleo passa pelos pontos de medição de produção, aquilo que é da União, nos termos do artigo 176 da Constituição Federal de 1988, passa para o domínio do concessionário, ocorrendo uma operação relativa à circulação de mercadoria passível de incidência do ICMS.

Considerando-se tal situação, pretende-se examinar, no presente trabalho, se o legislador estadual observou os limites da competência que lhe foi outorgado pela Constituição Federal para a produção de regra-matriz de incidência do ICMS, ao eleger a extração do petróleo como hipótese de incidência desse imposto.

Para tal desiderato, será analisado, no primeiro capítulo, o percurso que deve ser empreendido pelo intérprete para a construção da norma jurídica, a sua estrutura e as respectivas espécies, para que seja possível, dessa forma, discorrer sobre a regra-matriz de incidência.

Em seguida, discorreremos sobre a atividade da enunciação, compreendida como fonte de direito, e o seu produto (enunciação-enunciada e enunciados-enunciados). Com base nesses conceitos, analisaremos a norma de competência, a sua estrutura e os seus limites formais e materiais. No final do primeiro capítulo, abordaremos o papel da lei complementar em matéria tributária, que assume grande importância na regulamentação do ICMS.

No segundo capítulo, investigaremos o perfil constitucional do ICMS mercantil, que nos interessa no presente estudo, e em seguida construiremos a regra-matriz constitucional desse imposto.

O terceiro capítulo será dedicado à análise do tratamento constitucional e infraconstitucional conferido ao petróleo. Nesse capítulo, abordaremos a evolução dos regimes de mineração no Brasil desde o Período Colonial até os dias atuais, bem como os enunciados constitucionais que dispõem sobre as atividades econômicas do monopólio da União sobre esse bem, prescritas no artigo 177 da Carta Maior e a sua "flexibilização" com o advento da Emenda Constitucional n ${ }^{\circ}$ 9/95, além das denominadas participações governamentais.

Essa análise é essencial para a devida compreensão do contexto constitucional em que se insere a temática da exploração do petróleo pelos concessionários. 
Com base nas considerações feitas nos capítulos anteriores, analisaremos, no quarto capítulo, se foram observados os limites da norma de competência para a produção da norma veiculada pela Lei $n^{\circ} 4.117 / 03$. Para tal objetivo, será composta a regra-matriz de incidência a partir dos enunciados prescritivos veiculados pela aludida lei e analisados todos os critérios componentes dessa norma (material, espacial, temporal, pessoal e quantitativo), além do princípio da não cumulatividade do ICMS. 


\section{CAPÍTULO 1: CONCEITOS FUNDAMENTAIS}

\subsection{Fixação do objeto}

Conhecimento é toda forma de consciência (pensamento, lembrança, imaginação) que aprisiona um objeto (item pensado, lembrado, imaginado) intelectualmente como seu conteúdo. Entretanto, o conhecimento atinge sua plenitude quando o conteúdo aparece na forma de juízo (uma das modalidades do pensamento) ${ }^{1}$, submetendo-se ao critério de infirmação ou confirmação.

O pensamento se aperfeiçoa em três estágios. Os objetos são, inicialmente, apreendidos na forma de ideias, que são representados linguisticamente por termos (homem). O julgamento produz os juízos, representados pelas proposições (homem é mamífero) e a conjunção dos juízos se manifesta como raciocínio (homem é mamífero, mamífero é animal, então homem é animal).

Todo o conhecimento é proposicional, ou seja, só existe com a construção e relação dos juízos. Por isso não há conhecimento sem linguagem. Nos dizeres de PAULO DE BARROS CARVALHO, conhecer significa "saber emitir proposições sobre determinadas situações, pessoas ou coisas" ${ }^{2}$, ou seja, pode-se dizer que se conhece certo objeto se dele se pode discorrer, descrever.

Vale dizer, o objeto surge com o discurso, por meio dos atos de fala. Por isso, podemos dizer que o objeto nasce quando dele se fala. Nesse sentido, LUDWIG WITTGENSTEIN pontifica: "os limites da minha linguagem significam o limite do meu mundo". Em outras palavras, o meu conhecimento está limitado até onde consigo descrevê-lo em linguagem.

No presente trabalho, o objeto de análise é o direito positivo, composto das normas jurídicas válidas em determinado país, que se destinam a regular a conduta das pessoas nas relações de intersubjetividade.

A abordagem está circunscrita à análise dos elementos componentes da regramatriz constitucional do ICMS mercantil para que seja possível, dessa forma, concluir se a extração do petróleo se enquadra como operação relativa à circulação de mercadorias.

\footnotetext{
${ }^{1}$ CARVALHO. Paulo de Barros. Direito Tributário, Linguagem e Método. 3 ed. São Paulo: Noeses, 2011. p. 12.

${ }^{2}$ Ibid., 252.
} 
Adotou-se, neste trabalho, o método do construtivismo lógico-semântico, que representa o instrumento por meio do qual o sujeito do conhecimento (cientista) se aproxima do direito positivo (objeto), utilizando-se da linguagem para construir a norma jurídica, com base no método analítico.

\subsection{Percurso da construção dos sentidos dos textos jurídicos}

Durante muitos anos prevaleceu a ideia de que a interpretação estava associada à revelação do conteúdo contido no texto, ou seja, o texto já era dotado de sentido, cabendo ao intérprete apenas encontrar a significação preexistente.

No entanto, com a mudança de paradigma propiciada pelo giro linguístico, cujo marco inicial é marcado pela célebre obra de LUDWIG WITTGENSTEIN (Tratactus logico-philosophicus), a própria linguagem cria o objeto, ou seja, as palavras deixam de ter um conteúdo ontológico (vinculado às coisas) e passa a ser construído pelo intérprete.

Isso significa que o sentido não está oculto no texto. $\mathrm{O}$ texto é significativo, mas não contém significações (seu conteúdo). Serve apenas como estímulo para a produção de sentido. Vale dizer: as significações não estão atreladas aos signos, mas são construídas na mente do homem, que interpreta o suporte físico.

Nesse diapasão, vale citar as lições de LOURIVAL VILLANOVA, para quem “interpretar é atribuir valores aos símbolos, isto é, adjudicar-lhes significações e, por meio dessas, referências a objetos" 3 .

Da mesma forma ocorre com a interpretação dos textos jurídicos. O intérprete se depara com os enunciados prescritivos (artigos, incisos e parágrafos de uma lei) que compõem o suporte físico do direito positivo. Esses enunciados se reportam às condutas intersubjetivas, que são o seu significado e despertam, na mente do homem, a construção da norma jurídica, que é a sua significação.

Assim, as normas jurídicas não são extraídas dos textos do direito positivo, mas construídas pelo intérprete a partir deles, como explica PAULO DE BARROS CARVALHO:

Uma coisa são os enunciados prescritivos, isto é, usados na função pragmática de
prescrever condutas; outras, as normas jurídicas, como significações construídas
a partir dos textos positivados e estruturados consoante a forma lógica dos juízos

\footnotetext{
${ }^{3}$ VILLANOVA, Lourival. O universo das fórmulas lógicas e o Direito. Escritos jurídicos e filosóficos. São Paulo: IBET, 2003. 1v. p. 15.
} 
condicionais, compostos pela associação de duas ou mais proposições prescritivas.

$\mathrm{Na}$ composição da norma, o intérprete deve fazer incursões pelo sistema, recorrendo a diversos textos de lei para buscar, entre os diferentes diplomas normativos, a integridade existencial da norma.

Para a construção de sentido dos textos jurídicos e perfeita compreensão do conteúdo legislado, deve o intérprete percorrer quatro planos, quais sejam: S1 (plano dos enunciados); S2 (plano das proposições); S3 (plano das normas jurídicas) e S4 (plano da sistematização), os quais serão expostos sinteticamente a seguir.

O plano S1 é composto do conjunto de enunciados prescritivos, definido por PAULO DE BARROS CARVALHO como "[...] um conjunto estruturado de letras, palavras, frases, períodos e parágrafos graficamente manifestados nos documentos produzidos pelos órgãos de criação do direito" ${ }^{4}$. Esse é o primeiro contato do intérprete com a mensagem legislada, sendo a base material para construção das significações jurídicas.

Os enunciados possuem uma acepção dúbia, como esclarece PAULO DE BARROS CARVALHO, pois " [...] pertencem ao plano da literalidade textual, suporte físico das significações, ao mesmo tempo em que participam do plano do conteúdo, com o sentido que necessariamente suscitam" 5 .

Assim, para evitar a ambiguidade desse vocábulo, devemos distinguir enunciado (componente do plano da literalidade textual) de proposição (sentido atribuído aos símbolos que compõem esse plano, apresentando-se como juízo construído pelo intérprete). Após o isolamento da base física do texto que pretende compreender, o intérprete ingressa no plano dos conteúdos, atribuindo valores aos símbolos constantes no plano S1, compondo segmentos portadores de sentido. Esse é o plano S2.

A atribuição de sentidos aos enunciados prescritivos pelo intérprete nos permite afirmar que as proposições produzidas não são extraídas do texto normativo, mas produzidas pelo próprio intérprete.

As significações elaboradas nesse plano tem por base enunciados isolados, que ainda não possuem forma deôntica, ou seja, não são estruturadas de forma implicacional, característica do plano das significações normativas (plano S3).

\footnotetext{
${ }^{4}$ CARVAlHO, Paulo de Barros. Direito Tributário: fundamentos jurídicos da incidência. $6^{\mathrm{a}}$ ed. São Paulo: Saraiva, 2008. p. 62.

${ }^{5}$ CARVAlHO, Paulo de Barros. Curso de Direito Tributário. 23ª ed. São Paulo: Saraiva, 2011. p. 149.
} 
Nesse plano, as proposições elaboradas devem ser estruturadas em antecedente e consequente, ligadas por um vínculo implicacional, para a construção da mensagem jurídica de sentido deôntico completo.

Logo, a norma não é uma simples proposição, mas uma proposição estruturada na fórmula hipotético-condicional $(\mathrm{H} \rightarrow \mathrm{C}$ ), que decorre de um trabalho mental de construção e estruturação das significações.

A norma jurídica não se confunde, portanto, com os enunciados prescritivos que lhe servem de base (elementos do plano S1) nem com as proposições que a compõem, pertencentes ao plano $\mathrm{S} 2$.

O plano S4 é o plano da sistematização dos textos jurídicos. Nesse plano, o intérprete estabelece os vínculos de subordinação e coordenação entre as normas construídas no plano S3 para verificar a fundamentação jurídica das normas, detectando vícios de legalidade e constitucionalidade.

Segundo PAULO DE BARROS CARVALHO, esse plano é composto pelas "regras de estrutura", que são finitas, mas aptas a gerar infinitas normas. Ainda nos dizeres do Professor,

[...] é a Gramática Jurídica, subconjunto de regras que estabelecem como outras devem ser postas, modificadas ou extintas, no interior de certo sistema. São unidades da mesma espécie daquelas produzidas no Plano S3, com a particularidade de participarem na composição do sistema jurídico-normativo como conjunto autorreferencial, ou seja, como um domínio que se autoconstitui num processo dialético interno ${ }^{6}$.

Para ilustrar a importância desse plano, AURORA TOMAZINI DE CARVALHO fornece o seguinte exemplo:

Tomamos um exemplo: no percurso gerador de sentido da Lei n. 9.393/96,
transpondo os planos S1, S2 e S3, o intérprete constrói a norma jurídica tributária
do ITR (imposto territorial rural), mas como ele sabe que tal norma não existe
isoladamente, passa a relacioná-la com outras normas por ele construídas com
base naquele ou outros suportes físicos. Estabelece, assim, vínculos de
subordinação entre a norma constitucional de competência tributária e a norma
do ITR, posicionando aquela num patamar hierárquico superior e entre a do ITR
e a construída a partir do auto de infração lavrado pela autoridade administrativa,
posicionando esta num patamar hierárquico inferior. Estabelece também relações
de coordenação entre a norma tributária do ITR e outras também construídas a
partir da Lei n. 9.393/96, como as de multa pelo não pagamento do tributo, as
que instituem deveres instrumentais (i.e. entrega da DIAC - documento de
informação e atualização cadastral; e da DIAT - documento de informação e
apuração do ITR), as que fixam multas pelo não cumprimento de tais deveres; e

${ }^{6}$ CARVALHO, Paulo de Barros. Curso de Direito Tributário, p. 159. 
outras construídas a partir de enunciados veiculados por outros documentos (...). Neste esforço acaba por construir o sistema jurídico da tributação territorial rural $^{7}$.

Nesse plano, destacamos a importância da regra-matriz de incidência do ICMS, que permitirá verificar se os critérios dessa norma, que serão construídos a partir dos enunciados prescritivos veiculados pela Lei Estadual $\mathrm{n}^{\mathrm{o}} 4.117 / 03$, guardam compatibilidade com os critérios constitucionais desse imposto.

Em suma, o processo de construção do sentido dos textos jurídicos exige a incursão, pelo exegeta, pelos planos $S 1$, S2 e S3 para a construção da norma jurídica.

Inicialmente, o intérprete se depara com o dado físico do direito (S1), atribuindo sentido aos enunciados prescritivos para construir proposições isoladas, que ainda não possuem sentido deôntico (S2). Posteriormente, passa a ordenar as proposições na forma implicacional $(\mathrm{H} \rightarrow \mathrm{C})$, para construir uma mensagem jurídica dotada de sentido completo (S3), estabelecendo relações de subordinação e coordenação entre elas (S4).

\subsection{Norma jurídica em sentido amplo e em sentido estrito}

Conforme bem assinalado por PAULO DE BARROS CARVALHO, o termo "norma jurídica" é utilizado para nominar, de forma indiscriminada, as unidades do sistema positivo, que se apresenta nos quatro planos distintos descritos anteriormente (S1, $\mathrm{S} 2, \mathrm{~S} 3$ e $\mathrm{S} 4)$.

De fato, a norma jurídica pode se referir aos enunciados prescritivos (plano S1), as significações isoladamente consideradas (plano S2) e as significações estruturadas de forma deôntica (plano S3), que mantêm relação de coordenação e subordinação entre si (plano S4).

Em razão dessa ambiguidade, o Professor distingue as normas jurídicas em sentido amplo - "para aludir aos conteúdos significativos das frases do direito posto, vale dizer, aos enunciados prescritivos, não enquanto manifestações empíricas do ordenamento, mas como significações que seriam construídas pelo intérprete" - das normas jurídicas em sentido estrito, que são a composição articulada dessas significações, que produzem mensagem com sentido deôntico completo ${ }^{8}$.

\footnotetext{
${ }^{7}$ CARVAlHO, Aurora Tomazini. Curso de Teoria Geral do Direito. $2^{\text {a }}$ ed. São Paulo: Noeses, 2010. p. 251 e 252.

${ }^{8}$ CARVALHO, Paulo de Barros. Direito Tributário, linguagem e método, p. 128.
} 
Portanto, nos planos S1 e S2 o intérprete se depara com as normas jurídicas em sentido amplo, ao passo que no plano S3 estão as normas em sentido estrito, significações construídas a partir dos enunciados prescritivos na forma hipotético-condicional:" $\mathrm{D} \rightarrow(\mathrm{H}$ C)" - se ocorrer o fato $\mathrm{H}$, então deve ser a relação intersubjetiva $\mathrm{C}$.

Toda e qualquer norma em sentido estrito apresenta a mesma esquematização formal: uma proposição antecedente $(\mathrm{H})$, descritora de um fato, que, se verificado no campo da realidade social, implicará uma proposição consequente $(\mathrm{C})$, atrelando dois ou mais sujeitos de direito em torno de uma conduta regulada como obrigatória, permitida ou proibida.

A estrutura formal da norma jurídica em sentido estrito é sempre a mesma, não se altera. No entanto, os conteúdos significativos das normas em sentido estrito não são constantes. Por isso, o direito positivo é um sistema sintaticamente homogêneo e semanticamente heterogêneo.

Essa estrutura formal é necessária para que os comandos jurídicos sejam bem compreendidos. Por esse motivo LOURIVAL VILANOVA considera a norma jurídica como a expressão mínima e irredutível de manifestação do deôntico.

A norma, portanto, é o resultado do trabalho mental do intérprete de construção e estruturação das significações na forma hipotético-condicional. A norma não se encontra no texto do direito positivo, não está nele impregnada, mas é construída pelo intérprete a partir dele.

\subsection{Estrutura da norma jurídica}

Como exposto anteriormente, a norma jurídica tem estrutura implicacional própria da causalidade (relação de causa e efeito). É composta, portanto, de duas proposições (implicante e implicada) ligadas por um conectivo condicional $(\rightarrow$ ) imposto por um ato de vontade da autoridade que legisla (dever-ser neutro interproposicional).

A proposição implicante (hipótese ou antecedente) descreve um evento de possível ocorrência no mundo social. A proposição implicada (consequente ou tese) prescreve uma relação entre dois ou mais sujeitos, modalizada como obrigatória, proibida ou permitida (dever-ser neutro modalizado). Em síntese, toda norma jurídica apresenta a seguinte estrutura: 


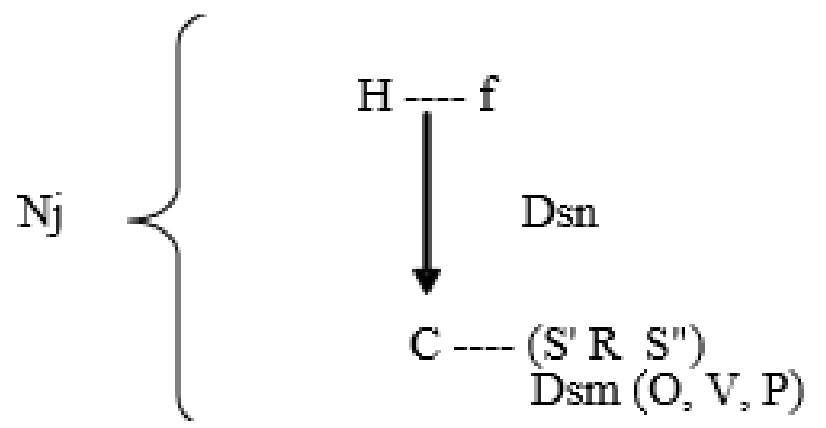

$\mathrm{Nj}$ : norma jurídica

H: hipótese

f: referência a um fato

Dsn: Dever-ser neutro

$\longrightarrow$ : conectivo implicacional

$\mathrm{C}$ : consequente

S' e S': sujeitos

$\mathrm{R}$ : variável relacional

Dsm: dever-ser modalizado - obrigatório $(\mathrm{O})$, proibido $(\mathrm{V})$ e permitido $(\mathrm{F})$

Analisemos, a seguir, cada um dos elementos que compõem a estrutura da norma.

\subsubsection{O antecedente normativo}

Como visto anteriormente, a hipótese, pressuposto ou antecedente descreve um evento de possível ocorrência no campo da experiência social (por exemplo: se vender mercadorias, se for proprietário de imóvel rural) que, se verificado, ensejará efeitos jurídicos.

Como todos os demais conceitos, a hipótese é seletor de propriedades, ou seja, opera como "redutor das complexidades dos acontecimentos recolhidos valorativamente" 9 .

Dessa forma, o legislador escolhe, dentre inúmeras possibilidades, apenas algumas juridicamente relevantes. Para desempenhar essa função, estabelece as notas que determinados acontecimentos precisam ter para serem considerados fatos jurídicos.

Já os acontecimentos não descritos na hipótese não são relevantes para o direito. Podem ensejar efeitos sociais e econômicos, mas não produzem efeitos na ordem jurídica.

Como ensina LOURIVAL VILANOVA:

\footnotetext{
${ }^{9}$ CARVALHO, Paulo de Barros . Direito Tributário, linguagem e método, p. 132.
} 
[...] a hipótese apesar de sua descritividade, é qualificadora normativa do fáctico. $\mathrm{O}$ fato se torna fato jurídico porque ingressa no universo do direito através da porta aberta que é a hipótese. E o que determina quais propriedades entram, quais não entram, é o ato-de-valoração que preside à feitura da hipótese da norma. ${ }^{10}$

Os eventos descritos no antecedente devem, necessariamente, pertencer ao campo do possível, pois, se fizer alusão a um fato impossível, jamais se instalará uma relação jurídica entre dois ou mais sujeitos. Nesse caso, a norma não terá eficácia social, ou seja, será um "sem-sentido deôntico" "11, como esclarece PAULO DE BARROS CARVALHO.

A relação semântica estabelecida entre a hipótese e a linguagem da realidade social é de cunho declarativo e não cognoscente do real. Vale dizer, não se submete a critério de verificação empírica, assumindo os valores "verdadeiro" e "falso", mas apenas tipifica um conjunto de eventos. Nesse sentido, LOURIVAL VILANOVA assevera:

[...] a hipótese, que é proposição descritiva de situação objetiva do possível, é construção valorativamente tecida, com dados-de-fato, incidente na realidade e não coincidente com a realidade. Falta-lhe, pois status semântico de enunciado veritativo. As hipóteses de norma valem ou não valem ${ }^{12}$.

\subsubsection{O operador deôntico}

$\mathrm{Na}$ estrutura normativa, existem dois operadores deônticos: o inter-proposcional e o interproposicional.

O primeiro conecta o antecedente ao consequente por um ato de vontade do legislador. Não aparece modalizado. É sempre neutro. O segundo, presente no consequente da norma, impõe uma relação entre dois ou mais sujeitos em torno de uma previsão de conduta obrigatória, permitida ou proibida. Aparece, portanto, sempre modalizado.

\subsubsection{O consequente normativo}

Diversamente da proposição-antecedente, que descreve um fato de possível ocorrência no mundo social, a proposição-tese prescreve condutas intersubjetivas, unindo dois ou mais sujeitos em torno de uma conduta regulada como proibida, permitida ou obrigatória.

${ }^{10}$ VILANOVA, Lourival. As estruturas lógicas e o sistema do Direito Positivo. 4 ed. São Paulo: Noeses. p. 52.

${ }^{11}$ CARVALHO, Paulo de Barros. Direito Tributário, linguagem e método, p. 133.

12 VILANOVA, Lourival. Op. Cit., p. 53. 
Nota-se, assim, que a relação de cunho semântico estabelecida entre o consequente normativo e a linguagem social é prescritiva. Vale dizer: o consequente nada descreve, apenas prescreve uma conduta, estabelecendo um vínculo entre o sujeito ativo, que detém o direito subjetivo de exigir certa prestação do sujeito passivo.

Os critérios que informam o consequente devem guardar relação com o acontecimento descrito na hipótese, pois este á causa daquele. O sujeito deve estar vinculado ao fato que motivou a obrigação, proibição ou permissão e o objeto da prestação deve fazer referência ao acontecimento que deu causa à relação jurídica ${ }^{13}$.

Da mesma forma que ocorre na hipótese, a proposição-tese também se assenta no mundo ontológico das possibilidades, ou seja, as escolhas do legislador devem recair sobre condutas de possível ocorrência. Nesse sentido, PAULO DE BARROS CARVALHO explica:

Careceria de sentido deôntico obrigar alguém a ficar em uma sala, proibido de sair, se a sala estivesse trancada, de modo que a saída fosse impossível. Também cairia em solo estéril permitir, nessas condições, que a pessoa lá permanecesse. Ao disciplinar condutas intersubjetivas, o legislador opera no pressuposto da possibilidade. Ali onde houver duas ou mais condutas possíveis, existirá sentido em proibir, permitir ou obrigar certo comportamento perante outrem ${ }^{14}$.

\subsection{Norma jurídica completa}

Como já observado, a estrutura da norma jurídica é sempre a mesma: uma proposição-antecedente, que se associa a uma proposição-consequente, por meio da cópula do conectivo condicional.

Contudo, “[...] as regras jurídicas não existem isoladamente, mas sempre num contexto de normas com relações particulares entre si" ${ }^{15}$, como ensina PAULO DE BARROS CARVALHO.

\footnotetext{
${ }^{13}$ Nesse sentido, AURORA TOMAZINI DE CARVALHO fornece o seguinte exemplo: "Voltamos ao exemplo do acidente do casso: digamos que o sujeito A seja considerado juridicamente culpado e, por isso, obrigado a indenizar o sujeito B (vítima) do valor do prejuízo causado. O sujeito A, sob o qual incide a obrigação jurídica de indenizar, guarda estrita relação com o fato que motivou a indenização: ele deu causa ao acidente. Do mesmo modo o objeto da obrigação, qual seja: o valor a ser indenizado, correspondente ao prejuízo causado pelo acidente e não a um valor aleatório que não guarda qualquer relação com o fato" (Curso de Teoria Geral do Direito, p. 299).

${ }^{14}$ CARVALHO, Paulo de Barros. Direito Tributário, linguagem e método, p. 134.

${ }^{15}$ Ibid., p. 138.
} 
Partindo da premissa de que uma norma sempre está ligada a outras no sistema do direito positivo, pode-se afirmar que as regras possuem feição dúplice: (i) norma primária e (ii) norma secundária.

As duas entidades formam a norma completa, expressando a mensagem deônticajurídica na sua integridade constitutiva. Em síntese, a norma jurídica completa apresenta a seguinte estrutura formal:

$$
\begin{aligned}
& \mathrm{D}\left\{[\mathrm{H} \rightarrow \mathrm{C}] \vee\left\{\left[\mathrm{H}^{\prime}(-\mathrm{c}) \rightarrow \mathrm{S}\right]\right\}\right. \\
& \text { norma primária } \quad \text { norma secundária }
\end{aligned}
$$

A norma primária prescreve um dever, se e quando acontecer o fato previsto no suposto, ao passo que a norma secundária prescreve uma providência sancionatória aplicada pelo Estado-Juiz, em razão do descumprimento da conduta prevista na norma primária. "H' (-c)".

\title{
1.6. Espécies normativas
}

Além da distinção entre normas primárias e secundárias que vimos anteriormente, existem outras classificações relevantes adotadas pela doutrina, tais como (i) as normas de comportamento e as normas de estrutura; (ii) normas gerais, abstratas, individuais e concretas.

A fim de distinguir as normas de estrutura das normas de comportamento, PAULO DE BARROS CARVALHO pontifica:

\begin{abstract}
Os teóricos gerais do direito costumam discernir as regras jurídicas em dois grandes grupos: normas de comportamento e normas de estrutura. As primeiras estão diretamente voltadas para a conduta das pessoas, nas relações de intersubjetividade; as de estrutura ou de organização dirigem-se igualmente para as condutas interpessoais, tendo por objeto, porém, os comportamentos relacionados à produção de novas unidades deônticas-jurídicas, motivos pelos quais dispõem sobre órgãos, procedimentos e estatuem de que modo as regras devem ser criadas, transformadas ou expulsas do sistema ${ }^{16}$.
\end{abstract}

Portanto, as normas de estrutura estabelecem como devem ser criadas as normas jurídicas gerais e abstratas e individuais e concretas, enquanto as normas de comportamento visam atingir determinado comportamento dos sujeitos de direito, por

\footnotetext{
${ }^{16}$ CARVALHO. Paulo de Barros. Curso de Direito Tributário, p. 187.
} 
intermédio dos modais deônticos obrigatório, permitido e proibido. Incluem-se entre as primeiras as normas de competência e entre as últimas as regras-matrizes de incidência.

As normas gerais são aquelas que regulam o comportamento de número indeterminado de pessoas. Não há individualização dos sujeitos da relação. As individuais, por seu turno, individualizam os sujeitos ativo e passivo.

As normas abstratas têm por antecedente a descrição de um fato futuro e incerto não determinado no espaço e no tempo, e as concretas relatam um fato ocorrido no passado em tempo e espaços determinados.

Assim, as qualificações geral ou individual são atribuídas ao consequente, onde encontram os sujeitos da relação, ao passo que os predicados abstrato e concreto qualificam o antecedente normativo, que descreve um fato propulsor de efeitos jurídicos.

A combinação dessas normas permite classificá-las como (i) geral e abstrata; (ii) geral e concreta; (iii) individual e abstrata; e (iv) individual e concreta.

As normas gerais e abstratas têm como hipótese a descrição de um evento futuro e incerto e seu consequente prescreve uma relação entre sujeitos não determinados. Como exemplo, citem-se as normas que instituem tributos.

Importante salientar, contudo, que

[...] a norma geral e abstrata, para alcançar o inteiro teor de sua juridicidade, reivindica, incisivamente, a edição de uma norma individual e concreta. Uma ordem jurídica não se realiza de modo efetivo, motivando alterações no terreno da realidade social, sem que os comandos gerais e abstratos ganhem concreção em normas individuais ${ }^{17}$.

As normas gerais e concretas têm como hipótese a descrição de um evento passado e seu consequente prescreve relações de caráter geral, entre sujeitos não especificamente determinados. As normas introdutoras são normas gerais e concretas (dado o fato da realização do processo legislativo, as normas produzidas devem ser consideradas válidas).

As normas individuais e abstratas têm como antecedentes eventos futuros e incertos, mas prescrevem relações entre pessoas determinadas. Como exemplo, as normas condicionantes (se ocorrer algum dano, a seguradora deve pagar ao segurado o valor correspondente ao dano).

As normas individuais e concretas têm como hipótese um fato determinado no tempo e no espaço e, no consequente, estabelecem relações jurídicas entre sujeitos determinados. Exemplo: Dado o fato de João ter vendido mercadorias no Estado de Minas

\footnotetext{
${ }^{17}$ CARVALHO, Paulo de Barros. Direito Tributário, linguagem e método, p. 141.
} 
Gerais no dia 10/01/2013, deve ele recolher à Fazenda Pública desse Estado a quantia de $\mathrm{R} \$ 1.000,00$.

\subsection{A regra-matriz de incidência tributária}

A regra-matriz de incidência tributária, ou norma padrão de incidência, se insere entre as normas gerais e abstratas. São normas produzidas para incidir.

Por se tratar de norma, a regra matriz de incidência é construção do intérprete. PAULO DE BARROS CARVALHO a identifica como "uma norma jurídica em sentido estrito" ${ }^{18}$, porque assinala o "núcleo do impacto jurídico da exação", ou seja, aquele que institui o tributo.

Essa regra descreve em seu antecedente uma classe de fatos constituídos de condutas humanas passíveis de ocorrer no mundo concreto (critério material), que devam ocorrer em determinado território (critério espacial), indicando um dado momento em que se possa reputar ocorrido o fato (critério temporal), para que assim possa se deflagrar o consequente, no qual também de forma abstrata se devem descrever os elementos de uma relação jurídica, indicando os seus sujeitos, ativo e passivo (critério pessoal), bem como os dados necessários para se definir qual será a prestação devida (critério quantitativo).

O esquema padrão da regra-matriz de incidência pode ser representado da seguinte forma:

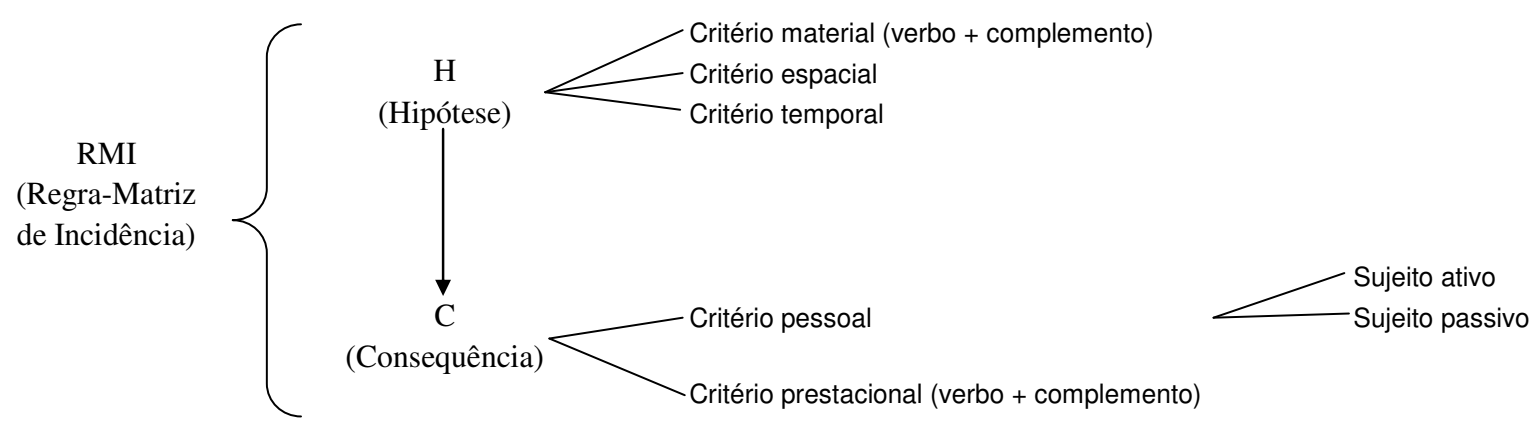

A esquematização formal da regra matriz é de grande utilidade, pois permite ao intérprete confeccionar, em sua representação mental, a norma jurídica padrão de incidência, permitindo uma análise dos componentes da hipótese e do consequente.

Além disso, o exame dos critérios componentes da regra-matriz é de extrema importância, como bem observa ROBSON MAIA LINS, para quem “[...] eventual

\footnotetext{
${ }^{18}$ CARVALHO. Paulo de Barros. Direito Tributário, linguagem e método, p. 604.
} 
declaração de inconstitucionalidade da RMIT pode ter por fundamento a incompatibilidade de um ou de alguns desses critérios com a Constituição Federal" ${ }^{19}$.

Neste trabalho, a construção da regra-matriz constitucional do ICMS mercantil será de grande valia, na medida em que fornecerá subsídios para verificar se os critérios estipulados pelo constituinte são compatíveis com aqueles veiculados pela Lei Estadual $\mathrm{n}^{\circ}$ 4.117/03, que instituiu o ICMS na extração do petróleo.

\subsubsection{A hipótese tributária e os seus critérios}

O legislador, ao escolher os fatos que deseja disciplinar, expede conceitos, selecionando, dessa forma, as notas que os acontecimentos sociais precisam ter para serem considerados fatos jurídicos.

Assim, a hipótese descreve uma situação futura, estabelecendo os critérios (conotação) que identificam o fato jurídico tributário.

Saliente-se também que, apesar de estar inserido na linguagem prescritiva do direito, o descritor não está sujeito aos valores de verdade e falsidade, características dos enunciados descritivos. As hipóteses das normas jurídicas valem ou não valem, como também as respectivas consequências (prescritores) têm validade ou invalidade.

$\mathrm{Na}$ hipótese, há a descrição de três critérios (i) critério material; (ii) critério espacial; e (iii) critério temporal. Passamos a descrevê-los:

\subsubsection{Critério material}

O critério material é um proceder humano, linguisticamente representado por um verbo e o seu complemento.

O verbo é sempre pessoal, de predicação incompleta e deve também estar no infinitivo, por fazer alusão a um comportamento no futuro. Nesse sentido, PAULO DE BARROS CARVALHO afirma:

[...] para a definição do antecedente da norma-padrão do tributo, quadra advertir que não se pode utilizar os da classe dos impessoais (como haver), ou aqueles sem sujeito (como chover), porque comprometeriam a operatividade dos desígnios normativos, impossibilitando ou dificultando seu alcance. Isso concerne ao sujeito, que pratica a ação, e bem assim ao complemento do

\footnotetext{
${ }^{19}$ LINS, Robson Maia. Controle de constitucionalidade da norma tributária. São Paulo: Quartier Latin, 2005. p. 86.
} 
predicado verbal, que, impreterivelmente, há de existir. Descabe falar-se, portanto, de verbos de sentido completo, que se expliquem por si mesmos. É forçoso que se trate de verbo pessoal e de predicação incompleta, o que importa a obrigatória presença de um complemento ${ }^{20}$.

Saliente-se, ainda, que o verbo pode exprimir tanto uma ação (vender mercadorias, industrializar produtos) como um estado (ser proprietário de veículo automotor).

Esclareça-se, por fim, que, como o verbo está no infinitivo, alguém sempre terá que realizar a ação ou se encontrar no estado descrito na hipótese. Por tal razão, não há necessidade da um critério pessoal na hipótese, pois toda atividade envolve, necessariamente, sujeitos.

No presente estudo, demonstraremos que o critério material eleito pelo legislador ordinário estadual (realizar operações de extração de petróleo) não se configura como uma operação relativa à circulação de mercadorias (critério material constitucional do ICMS mercantil).

\subsubsection{Critério espacial}

O critério espacial delimita o local em que o evento deve ocorrer para ser promovido à condição de fato jurídico. Nas palavras de LUCAS GALVÃO DE BRITTO ${ }^{21}$, o critério espacial da regra-matriz de incidência tributária é designado como “[...] feixe de enunciados, implícitos ou explícitos, que permitam identificar os marcos a serem empregados pelos intérpretes na atribuição de um lugar ao fato jurídico tributário".

De acordo com PAULO DE BARROS CARVALHO em alguns casos, o legislador estabelece expressamente o local em que o fato deve ocorrer, ao passo que em outros incumbe ao intérprete construir o critério espacial.

Segundo o Professor ${ }^{22}$, sob a perspectiva do critério espacial, os tributos podem ser classificados da seguinte forma:

\footnotetext{
${ }^{20}$ CARVAlHO. Paulo de Barros. Curso de Direito Tributário, p. 326.

${ }^{21}$ BRITTO, Lucas Galvão. O lugar e o tributo. Estudo sobre o critério espacial da regra-matriz de incidência tributária no exercício da competência tributária para instituir e arrecadar tributos. Dissertação de mestrado em Direito, PUC/SP, 2013, p.145.

22 "Há regras jurídicas que trazem expressos os locais em que o fato deve ocorrer, a fim de que irradie os efeitos que lhe são característicos. Outros, porém, nada mencionam, carregando implícitos os indícios que nos permitem saber onde nasceu o laço obrigacional. É uma opção do legislador. Aquilo que de real encontramos, no plano do direito positivo brasileiro, é uma dose maior ou menor de esmero na composição dos critérios espaciais, de tal modo que alguns são elaborados com mais cuidado que outros. Todavia, ainda que aparentemente pensemos ter o político se esquecido de mencioná-lo, haverá sempre um plexo de indicações, mesmo tácitas e latentes, para assinalar o lugar preciso em que aconteceu aquela ação, tomada como núcleo do suposto normativo" (CARVALHO. Paulo de Barros. Curso de Direito Tributário, p. 328).
} 
a) hipótese em que o critério material faz alusão a determinado local para a ocorrência do fato típico. Exemplo: tributos que gravam o comércio exterior, como o imposto de importação e de exportação, em que o acontecimento ocorre em local predeterminado (repartições alfandegárias);

b) hipótese em que o critério espacial alude a áreas específicas, de tal sorte que o acontecimento apenas ocorrerá se dentro delas estiver geograficamente contido. Exemplos: tributos que incidem sobre bens imóveis: IPTU e ITR;

c) hipótese de critério espacial bem genérico, onde todo e qualquer fato, que ocorra sob o manto da vigência territorial da lei instituidora, estará apto a desencadear seus efeitos. Exemplo: todos os demais tributos.

Deve-se salientar, contudo, que o critério espacial não se confunde com o âmbito espacial de vigência da norma, que é a delimitação territorial onde a norma está apta a produzir efeitos jurídicos. Assim, as leis municipais só irradiam efeitos dentro dos limites do seu território. Da mesma forma as normas produzidas pelos Estados e pela União, que podem propagar efeitos dentro dos limites territoriais estatais e brasileiro.

É importante salientar que o domínio espacial de vigência é fixado nos termos das disposições normativas, como bem expôs LUCAS GALVÃO DE BRITTO para quem é “[...] um equívoco achar que há um limite natural (como uma fração de terra, de água ou de ar) ou 'politicamente estabelecido' pela relação de soberania do Estado para com seus súditos, como já dizia HANS KELSEN”. Na visão do autor, da qual compartilhamos, o domínio espacial da vigência não corresponde, necessariamente, aos limites fronteiriços de um Estado. Segundo o autor, “[...] se assim sucede, é porque as disposições jurídicas assim estabeleceram, mas tal condição não é obrigatória, tanto que muito se fala em aplicação extraterritorial das leis" ${ }^{23}$.

A análise do critério espacial do ICMS mercantil, previsto constitucionalmente, nos levará à conclusão de que os Estados da federação não detêm competência para exigir o ICMS quando a extração do petróleo ocorre em águas marítimas (offshore).

\footnotetext{
${ }^{23}$ BRITTO, Lucas Galvão. O lugar e o tributo. Estudo sobre o critério espacial da regra-matriz de incidência tributária no exercício da competência tributária para instituir e arrecadar tributos, p. 149.
} 


\subsubsection{Critério temporal}

O critério temporal é definido como o preciso instante em que ocorre o fato jurídico, unindo credor e devedor em torno do dever tributário (por exemplo: saída da mercadoria do estabelecimento, no caso do ICMS).

Importante ressaltar que o legislador ordinário se descuidou ao destacar o critério temporal das normas tributárias em sentido estrito como se fosse o "fato gerador" do tributo (por exemplo: entrada do produto em território nacional é o critério temporal do imposto de importação, porém é mencionado pelo CTN como seu fato gerador - artigo 19).

É equivocada também a classificação do "fato gerador" como instantâneo, continuado e complexivo, pois tal distinção leva em conta fatos de ordem pré-jurídica, do mundo físico. Todo fato ocorre instantaneamente, como adverte PAULO DE BARROS CARVALHO:

\footnotetext{
O acontecimento só ganha proporção para gerar o efeito da prestação físcal, mesmo composto por mil outros fatores que se devam conjugar, no instante em que todos estiverem concretizados e relatados, na forma legalmente estipulada. Ora, isso acontece num determinado momento, num especial marco de tempo. Antes dele, nada de jurídico existe, em ordem ao nascimento da obrigação tributária. Só naquele átimo irromperá o vínculo jurídico que, pelo fenômeno da imputação normativa, o legislador associou ao acontecimento do suposto ${ }^{24}$.
}

Neste trabalho, demonstraremos que a passagem do petróleo pelos pontos de medição de produção não pode ser considerada o critério temporal da hipótese de incidência do ICMS, tal como foi eleito pelo legislador ordinário estadual por meio da Lei $\mathrm{n}^{\circ} 4.117 / 03$.

\subsubsection{O consequente e os seus critérios}

No consequente, o legislador seleciona as notas que as relações intersubjetivas precisam ter com a verificação do fato jurídico, indicando os elementos dessa relação, quais sejam, sujeitos (ativo e passivo) e o objeto da prestação (base de cálculo e alíquota).

O consequente é composto pelo critério pessoal e critério quantitativo, que serão detalhados a seguir.

\footnotetext{
${ }^{24}$ CARVAlHO, Paulo de Barros. Curso de Direito Tributário, p. 334.
} 


\subsubsection{Critério pessoal}

As informações contidas no critério pessoal permitem identificar os sujeitos da relação jurídica a ser instaurada quando da constituição do fato jurídico.

O sujeito ativo é o titular do direito subjetivo de exigir a prestação pecuniária, que pode ser tanto uma pessoa jurídica de direito público, dotada de capacidade política (pessoa política de direito público interno) como uma pessoa jurídica de direito privado, que não detém competência tributária (entidades paraestatais).

O sujeito passivo da obrigação tributária, por sua vez, é aquele que detém o dever jurídico de satisfazer a obrigação tributária. Pode ser pessoa física ou jurídica, pública ou privada, a qual, nos termos do artigo 121 do CTN, se diretamente relacionado com o fato jurídico tributário, configura contribuinte e, se indiretamente relacionado, reveste a condição de responsável, que é dividido em três espécies, de acordo com o CTN: (i) responsabilidade dos sucessores; (ii) responsabilidade de terceiros e (iii) responsabilidade por infrações.

No entender de PAULO DE BARROS CARVALHO ${ }^{25}$, essas relações que envolvem o responsável tributário tem natureza de sanção administrativa, pois a obrigação tributária só nasce contra o sujeito passivo que praticou o fato jurídico tributário.

A responsabilidade tributária dos sucessores está disciplinada nos artigos 130, 131, 132 e 133 do Código Tributário Nacional. A responsabilidade tributária ocorre quando a obrigação de pagar tributo, que nasce em face de determinado sujeito, se transfere para outrem em virtude da ocorrência de um fato posterior. É o que ocorre, por exemplo, com a pessoa natural ou jurídica de direito privado que adquire de outra fundo de comércio ou estabelecimento comercial e continua a exploração, ou com o espólio, pelos tributos devidos pelo de cujus até a data da sucessão, ou a pessoa jurídica de direito privado que resultar da fusão, transformação ou incorporação.

A responsabilidade tributária de terceiros está disciplinada no artigo 134 do CTN e a responsabilidade por infrações está contemplada no artigo 136, em que se impõe a responsabilidade objetiva do infrator, e no artigo 137, que aponta as situações em que a responsabilidade é pessoal do agente.

No que diz respeito à substituição tributária, PAULO DE BARROS CARVALHO critica a tradicional conceituação do substituto, em que um sujeito de direitos cede lugar a

\footnotetext{
${ }^{25}$ CARVAlHO, Paulo de Barros. Curso de Direito Tributário, p. 388.
} 
outro sujeito de direitos. Segundo o Professor, “[...] a modificação se traduz antes que o texto seja editado, em tempo que antecede o aparecimento da disciplina jurídica sobre a matéria” ${ }^{26}$. O regime jurídico da substituição é do substituído e não do substituto.

Na substituição para trás, o pagamento é postergado para um momento posterior à constituição do fato jurídico tributário. Trata-se de diferimento para o adimplemento na etapa subsequente da cadeia produtiva, por sujeito passivo diverso daquele que constituiu o fato jurídico. Já na substituição para frente, supõe-se a ocorrência do fato jurídico tributário no futuro para fazer a cobrança anteriormente.

A solidariedade, prescrita no artigo 124 do Código Tributário Nacional, ocorre quando duas ou mais pessoas, que possuem interesse comum, são simultaneamente obrigadas pelo pagamento da dívida integral. O interesse comum não representa um dado satisfatório para a definição de solidariedade, conforme define o artigo 124, inciso I, do CTN. De acordo com PAULO DE BARROS CARVALHO ${ }^{27}$, a solidariedade vai se instalar entre os sujeitos que estiverem no mesmo polo da relação, como ocorre com o imposto sobre transmissão de bens imóveis, quando dois ou mais são os compradores, ou com o ICMS, quando dois ou mais forem os comerciantes vendedores.

Como será demonstrado oportunamente, a Lei $n^{\circ} 4.117 / 03$ elegeu o extrator do petróleo como contribuinte do ICMS. A nosso ver, o legislador ordinário instituiu uma verdadeira substituição tributária, na medida em que conferiu a responsabilidade pelo pagamento do imposto ao concessionário, que seria adquirente da "mercadoria" e não ao seu "alienante", que seria a União.

\subsubsection{Critério quantitativo}

No tocante ao critério quantitativo, que consiste nos elementos que permitem a aferição exata do objeto prestacional da quantia a ser paga como tributo, sua formação se dá pela conjunção da base de cálculo e da alíquota.

A base de cálculo é entendida como a grandeza instituída que se destina, primordialmente, a dimensionar a intensidade do comportamento constante no núcleo do fato jurídico. Conforme os ensinamentos dos professores com quem nos alinhamos, existem três funções distintas para a chamada base calculada, quais sejam: (a) medir as proporções reais do fato, ou função mensuradora, (b) compor a específica determinação da

\footnotetext{
${ }^{26}$ CARVALHO, Paulo de Barros. Direito Tributário, linguagem e método, p. 648.
}

${ }^{27}$ Ibid., p. 654. 
dívida, ou função objetiva e (c) confirmar, infirmar ou afirmar o correto elemento material do antecedente normativo, ou função comparativa.

Com efeito, nos casos em que há descompasso entre o disposto na hipótese de incidência apontada pelo legislador e na base de cálculo por ele escolhida, deve-se fazer valer o disposto na base de cálculo, fazendo valer a autêntica natureza jurídica do tributo.

Já a alíquota, quando conjugada com a base de cálculo, “[...] dá a compostura numérica da dívida, produzindo o valor que pode ser exigido pelo sujeito ativo, em cumprimento da obrigação que nascera pelo acontecimento do fato típico"28.

As alíquotas podem assumir duas feições, conforme esclarece PAULO DE BARROS CARVALHO ${ }^{29}$ : a) um valor monetário fixo, ou variável em função de escalas progressivas da base de cálculo (por exemplo: \$1,20 por metro linear, de 100 a 300 metros, e assim por diante); ou b) uma fração, percentual ou não, da base de cálculo (que nesse caso será representada por quantia monetária).

Neste trabalho, entendemos que a base de cálculo prescrita na Lei 4.117/03 não mede as proporções reais do fato (valor da operação: preço da aquisição do petróleo).

\subsection{Fontes do Direito}

O termo "fonte" deriva do latim fons-fontis, que significa o lugar onde brota, na superfície da terra, a água. Nesse sentido, AURÉLIO BUARQUE DE HOLANDA FERREIRA define o conceito de fonte como: "1. Nascente de água, 2. Bica de onde corre a água potável para uso doméstico, 3. O depósito para onde corre, 4. Chafariz, 5. Pia batismal, 6. Aquilo que origina ou produz; origem, causa" ${ }^{30}$.

No uso da linguagem comum, a expressão "fontes de direito" é empregada para designar a origem das normas, ou seja, de onde o direito provém.

A doutrina trata esse tema de forma diversificada. Para KELSEN, a "fonte de direito" é definida como "[...] o fundamento de validade jurídico-positivo de uma norma jurídica, quer dizer, a norma jurídica positiva do escalão superior que regula a sua produção" ${ }^{31}$. De acordo com o entendimento do jusfilósofo, o direito regula sua própria criação, de forma que todas as normas têm como fundamento outra norma de dentro do sistema.

\footnotetext{
${ }^{28}$ CARVALHO, Paulo de Barros. Direito Tributário, linguagem e método, p. 405.

${ }^{29}$ Ibid., p. 406.

${ }^{30}$ FERREIRA, Aurélio Buarque de Holanda. Novo Aurélio. $4^{\mathrm{a}}$ ed. São Paulo: Nova Fronteira, 2010. p. 926.

${ }^{31}$ KELSEN, Hans. Teoria pura do Direito. $2^{\text {a }}$ ed. São Paulo: Martins Fontes, 2006 . p. 259.
} 
Assim, a Constituição é, para KELSEN, a fonte suprema do direito, pois regula a criação de todas as normas pertencentes ao direito positivo e todas as normas dela derivam.

MARIA HELENA DINIZ ${ }^{32}$ segrega as fontes de direito em materiais, que são os fatos que dão o conteúdo das normas jurídicas (fenômenos sociais), e formais, que são os meios em que as primeiras se apresentam no universo jurídico (leis, costumes, jurisprudências etc.).

TERCIO SAMPAIO FERRAZ JUNIOR ${ }^{33}$, por sua vez, esclarece que a expressão "fonte de direito" é uma "metáfora cheia de ambiguidades". Segundo o Professor,

[...] por fonte quer-se significar simultaneamente e, às vezes, confusamente, a origem histórica, sociológica, psicológica, mas também a gênese analítica, os processos de elaboração e de dedução das regras obrigatórias, ou ainda, a natureza filosófica do direito, seu fundamento e sua justificação.

Assevera o Professor que há uma imprecisão ao afirmar lei, costume, jurisprudência como fontes de direito, que ora é usado no sentido de fonte (regra de estrutura) ora como norma jurídica (elemento do sistema).

PAULO DE BARROS CARVALHO entende que fontes de direito são "[...] os focos ejetores de regras jurídicas, isto é, os órgãos habilitados pelo sistema para produzirem normas, numa organização escalonada, bem como a própria atividade desenvolvida por essas entidades, tendo em vista a criação de normas" ${ }^{34}$. Segundo o Professor, toda norma jurídica é introduzida no sistema do direito positivo por outra norma, a qual é denominada "veículo introdutor de normas". Assim, pode-se falar em normas introduzidas e normas introdutoras.

Feita a incursão pela doutrina, passa-se a expor o entendimento adotado nesse trabalho acerca da expressão "fontes de direito".

\subsubsection{A enunciação como fonte de Direito e o seu produto (enunciado)}

O traço marcante do positivismo jurídico é a consideração do Direito como um produto da vontade humana, que possui fundamento de validade diverso do direito natural. O direito não é um dado, pois não existe in natura, como assevera NORBERTO BOBBIO:

\footnotetext{
${ }^{32}$ DINIZ, Maria Helena. Compêndio de introdução à ciência do Direito. $8^{a}$ ed. São Paulo: Saraiva, 1995. p. 256.

${ }^{33}$ FERRAZ JUNIOR, Tercio Sampaio. Introdução ao estudo do Direito: técnica, decisão e dominação. $6^{\text {a }}$ ed. São Paulo: Atlas, 2011. p. 192.

${ }^{34}$ CARVALHO, Paulo de Barros. Direito Tributário, linguagem e método, p. 414.
} 
Se tivesse de exprimir com a fórmula mais breve possível qual a diferença entre a atitude perante o direito de um positivista e de um não-positivista (seja um teórico do direito natural, um discípulo da escola histórica ou o defensor de uma concepção sociológica do direito), responderia que a diferença pode ser reduzida à contraposição do direito como um produto e a consideração do direito como um dado. Positivista é aquele que acredita firmemente que o direito não existe in natura, não existe na sociedade e, portanto, não se trata de descobri-lo e de revelá-lo, mas é sempre a expressão de uma atividade humana consciente (mas também inconsciente), e se trata no máximo de interpretá-lo, tendo presente todo modo que também a interpretação é, por sua vez, uma obra de criação ou de recriação permanente ${ }^{35}$.

Com base nessa concepção, KELSEN elaborou uma teoria geral dos sistemas normativos. Segundo essa teoria, existem duas espécies de sistemas normativos: o sistema estático e o sistema dinâmico.

O primeiro é constituído por normas que se deduzem uma das outras. Vale dizer, o fundamento de validade e o conteúdo de validade são deduzidos de uma norma pressuposta fundamental. Para ilustrar esse sistema, KELSEN dá o seguinte exemplo:

[...] as normas não devemos mentir, não devemos fraudar, devemos respeitar os compromissos tomados, não devemos prestar falsos testemunhos, podem ser deduzidos de uma norma que prescreve a veracidade. Da norma segundo a qual devemos amar o próximo podemos deduzir as normas: não devemos fazer mal ao próximo, não devemos, especialmente, causar-lhe a morte, não devemos prejudica-lo moral ou fisicamente, devemos ajudá-lo quando precise de ajuda ${ }^{36}$.

Já o sistema dinâmico é composto por normas que se produzem umas por meio das outras, mediante uma relação de delegação de um poder superior a um poder inferior. De acordo com KELSEN,

[...] a norma fundamental limita-se a delegar numa autoridade legisladora, quer dizer, a fixar uma regra em conformidade com a qual devem ser criadas as normas desse sistema. A norma que constitui o ponto de partida da questão não vale por força do seu conteúdo, ela não pode ser deduzida da norma pressuposta através de uma operação lógica ${ }^{37}$.

Para esclarecer esse sistema, o Mestre de Viena exemplifica:

Um pai ordena ao filho que vá a escola. À pergunta do filho: por que devo eu ir à escola, a resposta pode ser: porque o pai assim o ordenou e o filho deve obedecer às ordens do pai. Se o filho continua a perguntar: porque devo eu obedecer às ordens do pai, a resposta pode ser: porque Deus ordenou a obediência aos pais e nós devemos obedecer às ordens do Deus, quer dizer, se ele põe em questão a

\footnotetext{
${ }^{35}$ BOBBIO, Norberto. Direito e poder. $2^{\text {a }}$ ed. São Paulo: Editora Unesp, 2008. p. 124.

${ }^{36}$ KELSEN, Hans. Teoria pura do Direito, p. 218.

${ }^{37}$ Ibid., p. 219.
} 
validade desta norma, a resposta é que não podemos sequer pôr em questão tal norma, quer dizer, que não podemos procurar o fundamento da sua validade, que apenas a podemos pressupor. O conteúdo da norma que constitui o ponto de partida: o filho deve ir à escola, não pode ser deduzido desta norma fundamental $^{38}$.

Com base nessa premissa, KELSEN afirma que o sistema normativo moral ou de direito natural é deduzido, enquanto um sistema normativo jurídico é produzido.

$\mathrm{Na}$ linha defendida por KELSEN e BOBBIO, entendemos que o direito é produzido pelo homem, motivo pelo qual não é possível conceber o direito como um dado da natureza.

Assim, partindo da premissa de que o direito positivo é um corpo de linguagem que se materializa na forma de conjunto de enunciados prescritivos, pode-se concluir que o direito provém da atividade humana de produzir enunciados, que é denominada enunciação. Nos dizeres de TÁREK MOYSÉS MOUSSALEM, "toda produção de um enunciado (seja descritivo, seja prescritivo) subjaz a atividade de enunciação" 39 .

Segundo as lições de GABRIEL IVO ${ }^{40}$, o ato de enunciação é composto de duas fases: a fase pré-legislativa e a fase legislativa. Na primeira fase, desenvolvem-se as ações necessárias para a elaboração do anteprojeto introdutor de normas. A segunda fase consiste no processo legislativo, ou seja, o conjunto de atos que culmina na criação de um instrumento introdutor de normas, que se inicia com a iniciativa e se encerra com a publicação. Nessa fase, dois momentos são regulados pelo direito positivo: a regulação constitucional e a regulação não constitucional (infraconstitucional).

A partir dos enunciados prescritivos contidos na Constituição Federal, são construídas as normas de produção normativa que regulam a (i) competência, atribuindo a um sujeito a possibilidade de criar determinado veículo introdutor de normas; (ii) o procedimento, que disciplina a forma como a competência deve ser exercida para a criação de determinado instrumento introdutor de normas (processo legislativo); e (iii) a matéria a ser tratada, que pode ser regulada de diversas formas (determinado instrumento introdutor ou pessoa competente).

Portanto, a enunciação produz os enunciados prescritivos (produtos), que se dividem em (i) enunciação-enunciada e (ii) enunciado-enunciado. Nesse sentido, pontifica GABRIEL IVO:

\footnotetext{
${ }^{38}$ KELSEN, Hans. Teoria pura do Direito, p. 219.

${ }^{39}$ MOUSSALEM, Tárek Moysés. Fontes do Direito Tributário. São Paulo: Max Limonad, 2001. p. 78.

${ }^{40}$ IVO, Gabriel. Norma jurídica, produção e controle. São Paulo: Editora Noeses, 2006. p. 7/26.
} 
A (i) enunciação (...) é o ato de produzir o enunciado. Constitui o enunciado. Sem enunciação não há enunciado, por isso ela antecede-o sempre. O (ii) enunciado é o produto, o resultante da enunciação. $O$ enunciado, no entanto, além de comportar o enunciado propriamente dito, suporta as marcas da enunciação. É a (iii) enunciação enunciada. O simulacro da enunciação, que não se confunde com a própria enunciação. Esta é inacessível ao conhecimento, a não ser quando se promove o procedimento de catálise, ou seja, investigar a causa a partir da sua consequência. Da consequência (enunciação enunciada) investigase a causa (enunciação). O enunciado também contém o (iv) enunciado enunciado, que é a sequência enunciada sem as marcas da enunciação. $O$ enunciado enunciado é o conteúdo do texto, abstraído o seu processo. O enunciado sem a enunciação enunciada ${ }^{41}$.

Reside, nesse ponto, a discordância quanto ao sistema normativo dinâmico idealizado por KELSEN, porquanto uma norma jurídica não produz outros enunciados prescritivos, mas apenas disciplina o ato de enunciação que os produz. Os enunciados só existem porque alguém os enunciou. Portanto, as normas não existem por derivação uma das outras, como defende PAULO DE BARROS CARVALHO.

A enunciação, portanto, deve ser realizada nos moldes prescritos pelas regras que estabelecem a autoridade competente, o procedimento e a matéria a ser tratada $^{42}$.

Daí a importância do estudo da fonte, especialmente no presente trabalho, pois a análise da fonte permite detectar se os enunciados prescritivos foram criados em conformidade com as normas que fundamentam juridicamente a sua produção, bem como identificar a existência de vícios nessa atividade enunciativa que possam colocar em risco a permanência dos enunciados produzidos no sistema.

\footnotetext{
${ }^{41}$ IVO, Gabriel. Norma jurídica, produção e controle. São Paulo: Editora Noeses, 2006, XLV.

${ }^{42}$ Nesse sentido, AURORA TOMAZINI DE CARVALHO fornece o seguinte exemplo: "Imaginemos que o país está na iminência de uma epidemia e, no intuito de proteger a população, alguns parlamentares pretendem tornar obrigatório o uso contínuo de máscaras. A Constituição da República, em seu art. $5^{\circ}$, II, prescreve que 'ninguém será obrigado a fazer ou deixar de fazer alguma coisa senão em virtude de lei'. Diante desse enunciado, o ente interessado em tornar obrigatório o uso de máscaras passa, então, a procurar disposições jurídicas que prescrevem como deve proceder para criar uma lei. Logo se depara com o art. $61 \mathrm{e}$ seguintes da $\mathrm{CF}$, que dispõem sobre o processo legislativo e, em observância a tais dispositivos, é instaurado um procedimento para a produção de enunciados jurídicos que tornarão obrigatório o uso de máscara por toda a população. Um projeto de lei é apresentado à Câmara dos Deputados para votação. Aprovado pela maioria simples dos deputados, o projeto passa para a sanção ou promulgação do Senado. Se lá também é aprovado, o projeto passa para a sanção ou promulgação do Presidente da República e depois para a publicação. Com a publicação, os enunciados produzidos no processo legislativo ingressam no sistema e passam a ter força coercitiva. Está criada, portanto, a norma jurídica que obriga o uso de máscara por toda população. Diante desse exemplo, pergunta-se: Qual é a fonte do direito? A epidemia é o motivo da lei, aquilo que determina o ato de vontade do legislador, mas não é ela que produz o direito/dever de usar máscara. Sem o ato de vontade e a realização do procedimento próprio por autoridade competente, tal norma nunca existiria no ordenamento jurídico. É por isso que tomamos a enunciação como fonte de direito" (Curso de Teoria Geral do Direito, p. 654/655).
} 


\subsection{Competência tributária}

\subsubsection{Conceito}

Dentre as normas que compõem o sistema constitucional tributário estão incluídas normas de competência tributária, por meio das quais o Constituinte outorgou competência legislativa aos entes políticos (União, Estados, Municípios e Distrito Federal) para a instituição de tributos.

A expressão "competência tributária", como ocorre com quase todos os signos, é polissêmica. Em profundo estudo sobre a matéria, TÁCIO LACERDA GAMA expõe quatro sentidos de competência tributária:

i. por competência entendemos a aptidão para criar normas jurídicas que, direta ou indiretamente, disponham sobre a instituição, arrecadação ou fiscalização de tributos;

ii. norma de competência em sentido amplo engloba toda e qualquer proposição que concorra para programar essa aptidão;

iii. norma de competência em sentido estrito é o juízo hipotético condicional que prescreve, no seu antecedente, os elementos necessários à enunciação válida e, no seu consequente, uma relação jurídica que tem como objeto a validade do texto que verse sobre determinada matéria ou comportamento;

iv. a formação da norma de competência em sentido completo pressupõe reunir, além da norma de competência em sentido estrito, uma norma jurídica que prescreva a sanção pelo exercício ilegítimo daquela, ou seja, a reação do sistema pela criação de norma jurídica sem fundamento de validade ${ }^{43}$.

CRISTIANE MENDONÇA, por sua vez, identifica as seguintes acepções para o termo competência tributária:

Aptidão para criar tributos in abstrato;

Parcela do poder tributário de que são dotadas as pessoas políticas para instituir seus próprios tributos;

Poder de instituir e de exonerar tributos;

Poder para instituir, exigir e arrecadar tributos;

Competência legislativa plena de que são dotadas as pessoas políticas para instituírem os seus tributos;

Competência para legislar sobre matéria tributária;

Poder para legislar sobre tributos, administrar tributos e julgar litígios tributários; Poderíamos empregar, ainda, competência tributária com aptidão para criar tributos in concreto;

Norma jurídica que autoriza a criação e a alteração dos enunciados prescritivos veiculadores de tributos (normas gerais e abstratas ou individuais e concretas);

${ }^{43}$ GAMA, Tácio Lacerda. Competência tributária, fundamentos para uma teoria da nulidade. $2^{\mathrm{a}}$ ed. São Paulo: Noeses, 2011. p. 65/66. 
Autorização jurídico-positiva para a criação e a alteração dos enunciados prescritivos veiculadores de tributos (normas gerais e abstratas e individuais e concretas) ${ }^{44}$.

Após analisar as diversas acepções de competência, a autora elabora uma definição estipulava de competência tributária, como “[...] sinônima da autorização conferida pelo direito positivo às distintas pessoas políticas para a edição e a alteração de normas jurídicas tributárias em sentido estrito, quer gerais e abstratas, quer individuais e concretas" ${ } 45$.

PAULO DE BARROS CARVALHO ${ }^{46}$ pontifica que a competência tributária pode ser entendida como uma das prerrogativas legiferantes outorgadas às pessoas políticas, a qual consiste na possibilidade de legislar para a produção de normas jurídicas inaugurais sobre tributos ${ }^{47}$. Esse é o conceito que adotamos neste trabalho.

\subsubsection{Estrutura da norma de competência}

De acordo com a classificação empregada por BOBBIO $^{48}$, as normas de competência são regras de estrutura, pois não ferem diretamente as condutas interpessoais, mas estabelecem a forma pela qual as normas de conduta devem ser criadas, modificadas ou extintas:

\footnotetext{
Existem normas de comportamento ao lado de normas de estrutura. As normas de estrutura podem também ser consideradas como as normas para a produção jurídica: quer dizer, como as normas que regulam os procedimentos de regulamentação jurídica. Elas não regulam o comportamento, mas o modo de regular um comportamento, ou, mais exatamente, o comportamento que elas regulam é o de produzir regras.
}

\footnotetext{
${ }^{44}$ MENDONÇA, Cristiane. Competência tributária. São Paulo: Quartier Latin, 2004. p. 37.

${ }^{45}$ Ibid., p. 79.

${ }^{46}$ CARVALHO, Paulo de Barros. Direito Tributário, linguagem e método, p. 236.

${ }^{47}$ Além da competência tributária legislativa para a instituição de tributos, a competência tributária pode ser também administrativa, judicial e privada, já que as autoridades administrativas, os magistrados e os particulares têm a prerrogativa de produzir normas sobre tributos. Nesse sentido, PAULO DE BARROS CARVALHO ensina: "Não podemos deixar de considerar que têm, igualmente, competência tributária o Presidente da República, ao expedir um decreto sobre IR, ou seu ministro ao editar a correspondente instrução ministerial; o magistrado e o tribunal que vão julgar a causa; o agente da administração encarregado de lavrar o ato de lançamento, bem como os órgãos que irão participar da discussão administrativa instaurada com a peça impugnatória; aquele sujeito de direito privado habilitado a receber o pagamento de tributo (bancos, por exemplo); ou mesmo o particular que, por força de lei, está investido na condição de praticar a sequência procedimental que culminará com a produção de norma jurídica tributária, individual e concreta (casos de IPI, ICMS, ISS etc.)" (Direito Tributário, linguagem e método, p. 232).

${ }^{48}$ BOBBIO, Norberto. Teoria do ordenamento jurídico. $10^{\mathrm{a}}$ ed. Brasília: Universidade de Brasília, 1999. p. 45.
} 
Da mesma forma que as demais normas, considerando-se a homogeneidade sintática dos elementos do sistema jurídico, as normas de competência em sentido estrito se estruturam na forma de um juízo hipotético-condicional. Segundo CRISTIANE MENDONÇA $^{49}$, a estrutura da norma de competência pode ser descrita da seguinte forma:

\begin{abstract}
Antecedente: Se for pessoa política constitucional no território brasileiro no tempo X. Consequente: Deve ser a autorização (permissão ou imposição) para distintos sujeitos de direito (ocupantes de órgãos unipessoais ou colegiais), de acordo com determinados limites formais (relativos ao procedimento) e materiais (concernentes à substância dos enunciados a serem criados), editarem e revogarem (parcial ou totalmente) enunciados prescritivos instituidores de tributos - no plano geral e abstrato ou individual e concreto - e o dever jurídico de a comunidade respeitar o exercício de tal permissão (faculdade) ou o direito subjetivo de exigir o cumprimento da imposição (obrigatoriedade), em consonância com os limites (formais e materiais) previstos no sistema.
\end{abstract}

De acordo com a autora, a fórmula lógica da norma de competência pode ser representada da seguinte forma: $\mathrm{NCT}=\{\mathrm{Hct}=[\mathrm{Cm}+\mathrm{Ce}+\mathrm{Ct}] \rightarrow \mathrm{Cct}=[\mathrm{Cp}(\mathrm{Sa}+\mathrm{Sp})+$ $\mathrm{Cda}(\mathrm{Lf}+\mathrm{Lm})]\}^{50}$.

TÁCIO LACERDA GAMA esclarece que a regra de competência contém a programação formal e material da norma que o agente competente está autorizado a produzir. Quanto à forma, estabelece quem pode criar normas no direito tributário, por meio de qual procedimento e em que circunstância de espaço e de tempo. No âmbito material, determina acerca do que tais normas podem versar, além dos enunciados que qualificam sujeitos como competentes para instituir tributos sobre certas materialidades e/ou para criar normas voltadas à consecução de certas finalidades, os princípios, as imunidades e as proposições inseridas por lei complementar que dispõem sobre competência tributária legislativa. $\mathrm{O}$ autor adverte ainda que a produção normativa será

\footnotetext{
${ }^{49}$ MENDONÇA, Cristiane. Competência tributária, p. 69-70.

${ }^{50} \mathrm{NCT}=$ norma de competência tributária

Hct $=$ hipótese, antecedente ou suposto da norma de competência tributária

$\mathrm{Cm}=$ critério material da hipótese - ser pessoa de direito constitucional

$\mathrm{Ce}=$ critério espacial da hipótese - previamente definido (no território brasileiro)

$\mathrm{Ct}=$ critério temporal da hipótese - condicionantes de tempo

$\rightarrow$ dever-ser neutro - conectivo deôntico interproposicional

$\mathrm{Cct}=$ consequente ou prescritor da norma de competência tributária

$\mathrm{Cp}=$ critério pessoal do consequente onde estão os sujeitos da relação jurídica

$\mathrm{Sa}=$ sujeito ativo de competência tributária

$\mathrm{Sp}=$ sujeito passivo de competência tributária

$\mathrm{Cda}=$ critério delimitador da autorização - indica o que foi autorizado (editar normas gerais e abstratas ou individuais e concretas) com todos os limites formais e materiais estabelecidos no sistema

$\mathrm{Lf}=$ limites formais - estabelecem a forma (procedimento) de produzir os veículos introdutores das normas jurídicas tributárias (enunciação-enunciada)

Lm = limites materiais - delineiam a substância dos enunciados-enunciados a serem produzidos
} 
lícita ou ilícita - e a norma será válida ou inválida - conforme sejam ou não atendidos os requisitos prescritos pela norma de competência.

Deveras, a enunciação deve seguir a forma prescrita na regra de competência, o que significa dizer que só pode ser realizada pelo sujeito investido para tanto, por meio do veículo introdutor específico (por lei complementar, lei ordinária etc.), no local e no intervalo temporal previstos. Da mesma forma, o produto da enunciação (enunciado) deve respeitar a materialidade descrita na regra de competência, os princípios e as imunidades específicas.

\subsubsection{Limites formais para o exercício da competência}

Os limites formais da competência estabelecem o procedimento que deve ser observado pelo sujeito ativo da norma de competência (pessoa jurídica de direito público) para a produção da norma jurídica (enunciação).

O princípio da estrita legalidade, prescrita no artigo 150, inciso I, da Constituição Federal, exige que o instrumento introdutor de normas pela instituição ou majoração dos tributos seja a lei. Destarte, todos os critérios componentes da regra-matriz de incidência (material, espacial, temporal, pessoal e quantitativo) devem estar previstos em lei.

Em algumas situações, o texto constitucional expressamente prescreve o instrumento introdutor de normas para a instituição de certos tributos, como é o caso dos empréstimos compulsórios, que dependem da instituição de lei complementar (artigo 178, incisos I e II, da Constituição Federal). Noutros casos, o texto constitucional dá margem a dúvidas sobre o instrumento introdutor dessas normas, como ocorre, por exemplo, com o instrumento a ser utilizado para a instituição das contribuições sociais previstas no artigo 149, caput e $195, \S 4^{\circ}$ (lei ordinária ou lei complementar).

Segundo o escólio de GABRIEL IVO, "a competência não pode ser exercida de qualquer maneira". Cada instrumento introdutor de normas possui um procedimento específico, que é disciplinado pela Constituição Federal por meio do processo legislativo.

Insta também observar que a atividade de enunciação, compreendida como fonte do direito, exaure-se em si mesma, mas o seu produto registra não apenas o seu conteúdo (enunciado-enunciado), mas também a forma de sua produção que remete à atividade da enunciação, informando o processo, a autoridade competente e as coordenadas de espaço e tempo (enunciação-enunciada). 
Dessa forma, para detectar se os limites formais foram devidamente observados pelos sujeitos credenciados pelo sistema para a produção de normas, deve-se verificar a enunciação-enunciada, a partir da qual se constrói a norma introdutora (veículo introdutor de normas), cuja hipótese constitui a enunciação como fato jurídico e o consequente a juridicidade dos enunciados por ela produzidos.

A constatação quanto à inobservância dos limites formais por parte do órgão competente poderá resultar na invalidade do texto produzido, como obtempera TÁCIO LACERDA GAMA:

\footnotetext{
O modo de realizar a enunciação é, pois, um elemento fundamental na compostura interna da hipótese das normas de competência tributária. Ignorado qualquer dos seus aspectos, ou seja, feita a enunciação dos textos de direito positivo sem atenção a qualquer dos elementos previstos no modo de enunciação, o texto não terá sido enunciado de forma correta. Logo, a norma jurídica inserida por esse instrumento introdutor será inválida ${ }^{51}$.
}

Insta advertir, entretanto, que no nosso entendimento a decretação de invalidade do texto normativo depende de produção de outra norma, pelo órgão competente credenciado pelo sistema, reconhecendo a sua inconstitucionalidade formal.

Para a devida compreensão dessa afirmação, devemos discorrer, de forma sintética, sobre a validade das normas jurídicas.

Validade é uma relação de pertencialidade entre o elemento e um sistema. Um elemento pertence a um conjunto e, portanto, é válido se ele subsumir-se aos requisitos eleitos para a delimitação do conjunto, ou seja, aos critérios de pertencialidade.

Apesar da divergência doutrinária existente sobre o conceito de validade $^{52}$, entendemos validade como sinônimo de existência. Nesse sentido, servimo-nos das lições de PAULO DE BARROS CARVALHO, para quem

[...] a validade se confunde com a existência, de sorte que afirmar que uma norma existe, implica reconhecer sua validade em face de determinado sistema jurídico. Do que se pode inferir: ou a norma existe, está no sistema e é, portanto, válida, ou não existe como norma jurídica ${ }^{53}$.

\footnotetext{
${ }^{51}$ GAMA, Tácio Lacerda. Competência tributária, fundamentos para uma teoria da nulidade, p. 74.

${ }^{52}$ Existem duas grandes teorias sobre a validade: (i) uma que a considera como atributo da norma jurídica, como defende PONTES DE MIRANDA e (ii) outra que a trata como sinônimo de existência, como entendem KELSEN E PAULO DE BARROS CARVALHO.

${ }^{53}$ CARVALHO, Paulo de Barros. Direito Tributário, linguagem e método, p. 443.
} 
Para verificarmos se uma norma jurídica pertence ou não ao sistema, ou seja, se é ou não válida, utilizamo-nos de dois critérios: (i) a autoridade competente e (ii) o procedimento prescrito pelo direito.

A autoridade competente é aquela que está credenciada pelo sistema para produzir normas jurídicas; e o procedimento próprio diz respeito à forma prescrita pelo direito para a produção de enunciados prescritivos. Tanto um quanto o outro se encontram na enunciação-enunciada.

Deve-se salientar, contudo, que os "critérios de validade" não se confundem com "fundamento de validade". Uma coisa é validade, que é aferida como relação de pertencialidade da norma com o sistema. Outra coisa é a adequação da norma com as outras normas que disciplinam a sua produção e materialidade, que ocorre em um momento posterior.

Assim, não se pode afirmar que a validade da norma é presumida. As normas já nascem válidas ou inválidas, ou seja, são ou não jurídicas. A presunção diz respeito à adequação (formal e material) da enunciação-enunciada e do enunciado-enunciado às normas de superior hierarquia.

Vale dizer, enquanto não desconstituída por outra linguagem, presume-se que os enunciados foram produzidos por autoridade competente, o procedimento próprio foi respeitado, assim como a materialidade tem fundamento em norma de superior hierarquia.

Dessa forma, o controle de produção, ou seja, o confronto entre as normas introduzidas e aquelas que lhe são hierarquicamente superiores, é feito posteriormente. Segundo AURORA TOMAZINI DE CARVALHO,

[...] o controle recai sobre os dois tipos de normas constantes do documento normativo: (i) o veículo introdutor e (ii) as normas introduzidas. Quando a discrepância é verificada no veículo introdutor, dizemos que há vício formal, o que demonstra alguma inconformidade na enunciação-enunciada (i.e. autoridade incompetente ou falha no procedimento). Quando a discrepância é verificada nas normas introduzidas, dizemos que há vício material, o que demonstra alguma inadequação no conteúdo produzido ${ }^{54}$.

Portanto, uma norma flagrantemente inconstitucional só deixará de ser válida quando o fato da inconstitucionalidade for constituído por uma linguagem competente expedida pelo órgão competente. Nesse sentido, ROBSON MAIA LINS assevera:

\footnotetext{
${ }^{54}$ CARVALHO, Aurora Tomazini. Curso de Teoria Geral do Direito, p. 729.
} 
Na hipótese de retirada de norma do sistema jurídico via norma introduzida pelo STF no exercício do controle concentrado de constitucionalidade, temos que até o ato de publicação da norma introduzida e o seu trânsito em julgado, a RMIT permanece no sistema jurídico positivo ${ }^{55}$.

\title{
1.9.4. Limites materiais para o exercício da competência
}

Os limites materiais da norma de competência demarcam a matéria que poderá ser tratada pelo legislador infraconstitucional. Segundo o escólio de CRISTIANE MENDONÇA, tais limites são "[...] os enunciados constitucionais que prescrevem o conteúdo dos enunciados-enunciados a serem produzidos pelos legisladores infraconstitucionais, e que são responsáveis pela inserção das exações fiscais no bojo sistêmico" ${ }^{56}$.

Dentre esses limites, destacamos, inicialmente, a "norma padrão de incidência", o "arquétipo constitucional", que deve ser observado fielmente pelo legislador infraconstitucional para a criação do tributo, como apregoa ROQUE ANTÔNIO CARRAZA:

\begin{abstract}
A Constituição, ao discriminar as competências tributárias, estabeleceu - ainda que, por vezes, de modo implícito e com certa margem de liberdade para o legislador - a norma padrão de incidência (o arquétipo, a regra matriz) de cada exação. Noutros termos, ela apontou a hipótese de incidência possível, o sujeito ativo possível, o sujeito passivo possível, a base de cálculo possível e a alíquota possível, das várias espécies e subespécies de tributos. Em síntese, o legislador, ao exercitar a competência tributária, deverá ser fiel à norma padrão de incidência do tributo, pré-traçada na Constituição. O legislador (federal, estadual, municipal ou distrital), enquanto cria o tributo, não pode fugir deste arquétipo constitucional $^{57}$.
\end{abstract}

TÁCIO LACERDA GAMA, ao tratar sobre a programação da matéria, aponta quatro elementos fundamentais que integram a competência legislativa para instituir normas relativas à tributação: (i) os enunciados de autorização; (ii) os princípios; (iii) as imunidades e (iii) os enunciados complementares ${ }^{58}$.

Com relação aos enunciados de autorização ${ }^{59}$, o autor destaca três técnicas de atribuição de competência legislativa, quais sejam:

\footnotetext{
${ }^{55}$ LINS, Robson Maia. Controle de constitucionalidade da norma tributária, p. 81.

${ }^{56}$ MENDONÇA, Cristiane. Competência tributária, p. 46.

${ }^{57}$ CARRAZA, Roque Antônio. Curso de Direito Constitucional Tributário. 26a ed. São Paulo: Malheiros, 2010. p. 524.

${ }^{58}$ GAMA, Tácio Lacerda. Competência tributária, fundamentos para uma teoria da nulidade, p. 235.

59 "Denominamos enunciados de autorização a classe das proposições, enunciadas a partir do direito positivo, que qualificam sujeitos como competentes para instituir tributos sobre certas materialidades ou,
} 
(i) a qualificação do sujeito competente a partir da materialidade do tributo. A título exemplificativo, o artigo 153 da Constituição Federal outorgou competência à União para instituir impostos sobre a renda (auferir renda) e sobre as importações (promover importações);

(ii) a vinculação do sujeito competente a uma finalidade, tal como prescreve o artigo 149 - A da Carta Maior, facultando aos Municípios a instituição da contribuição destinada ao custeio da iluminação pública;

(iii) a qualificação do sujeito tanto a uma materialidade quanto à execução de um fim, como ocorre com a competência da União prevista no artigo $177, \S 4^{\circ}$ para criar contribuições sobre: "as atividades de importação ou comercialização de petróleo e seus derivados, gás natural e seus derivados e álcool combustível” para atender as seguintes finalidades: a) pagamento de subsídios a preços ou transporte de álcool combustível, gás natural e seus derivados de petróleo; b) financiamento de projetos ambientais relacionados com a indústria de petróleo e do gás; c) financiamento de programas de infra estrutura de transporte. Tomando esse exemplo, o autor conclui que o não atendimento da finalidade ou da matéria faz com que a norma criada não seja instrumento da União na respectiva área, descumprindo, assim, a norma superior e sujeitando-se à decretação de sua invalidade $^{60}$.

Os princípios são, para o autor, "proposições prescritivas que integram a norma de competência, condicionando a forma e a matéria que prescrevem, direta ou indiretamente, a instituição, a arrecadação e a fiscalização de tributos" 61 .

Os enunciados complementares são as proposições inseridas por lei complementar que devem ser considerados na formação da competência tributária. A título exemplificativo, o autor cita os empréstimos compulsórios (art. 148, I e II), a competência residual para a instituição dos impostos (art. 154, I) e as novas fontes de custeio para a seguridade social (art. 195, $\S 4^{\circ}$ ), bem como cita também a importância do artigo 146 da Carta Maior como instrumento de produção de enunciados de competência em matéria tributária.

A inobservância dos limites materiais da norma de competência, plasmados na Constituição Federal por parte dos órgãos habilitados pelo sistema para a produção das regras-matrizes de incidência, afetam os enunciados-enunciados por ele criados e ficam suscetíveis de ter a sua inconstitucionalidade material declarada pelo órgão jurisdicional competente.

diversamente, para criar normas voltadas à consecução de certas finalidades ou, ainda, para gravar materialidades e atingir finalidades. São exemplos da primeira classe os dispositivos que qualificam sujeitos para a instituição de impostos; da segunda classe, os que qualificam para a criação de empréstimos compulsórios e contribuições; e, da última, os que preveem competência para criação de contribuições para a seguridade social, em que se indica o fim e matéria. São também dessa classe as proposições que qualificam sujeitos para instituir normas relativas a deveres instrumentais, assim como à constituição, alteração, suspensão da exigibilidade e extinção das obrigações tributárias (Ibid., p. 235).

${ }^{60}$ GAMA, Tácio Lacerda. Competência tributária, fundamentos para uma teoria da nulidade, p. 235258.

${ }^{61}$ Ibid., p. 250. 
A análise desses limites para o exercício da competência tributária é essencial neste trabalho, pois iremos verificar se o legislador ordinário estadual, ao criar o ICMS que tem por hipótese de incidência a extração do petróleo, respeitou o arquétipo constitucional desse imposto, a Lei Complementar nº 87/96 e o princípio da não cumulatividade.

\subsubsection{Características da competência tributária}

Não há consenso entre os doutrinadores acerca dos atributos da competência tributária. ROQUE ANTÔNIO CARRAZA identifica seis deles, quais sejam: privatividade, indelegabilidade, incaducabilidade, inalterabilidade, irrenunciabilidade e facultatividade do exercício da competência. PAULO DE BARROS CARVALHO, por sua vez, afirma que apenas a indelegabilidade, irrenunciabilidade e incaducabilidade, que derivam do princípio da supremacia e rigidez da Constituição, se sustentam. Vejamos cada um deles.

(i) Privatividade - ROQUE ANTÔNIO CARRAZA afirma que as normas constitucionais que atribuem competência em matéria tributária encerram duplo comando: habilitando a pessoa contemplada, e somente ela, a criar, querendo, um dado tributo; e proibindo as demais de virem a instituí-1o ${ }^{62}$. Sendo competente uma pessoa, todas as demais seriam incompetentes.

PAULO DE BARROS CARVALHO ${ }^{63}$, por sua vez, discorda desse posicionamento. De acordo com o Professor, os impostos extraordinários poderão ser instituídos pela União nas situações previstas no artigo 154, II, da Constituição Federal ${ }^{64}$, com idênticas hipóteses de incidência e base de cálculo para vigorar na mesma área territorial de tributos instituídos pelos Estados, Municípios e Distrito Federal. As regrasmatrizes instituídas nessas circunstâncias incidiriam sobre a mesma realidade, num caso de bitributação constitucionalmente regulada.

(ii) Indelegabilidade - Em razão da existência de um sistema rígido de competências, o ente político que a recebeu não pode delegá-la a outros. Caso isso fosse possível, o sistema não seria rígido, como bem salientou PAULO DE BARROS CARVALHO:

\footnotetext{
${ }^{62}$ CARraZA, Roque Antônio. Curso de Direito Constitucional Tributário, p. 529.

${ }^{63}$ CARVAlHO, Paulo de Barros. Curso de Direito Tributário, p. 275.

64 “Art. 154: A União poderá constituir: (...)

II - na iminência ou no caso de guerra externa, impostos extraordinários, compreendidos ou não em sua competência tributária, os quais serão suprimidos, gradativamente, cessadas as causas de sua criação."
} 
Por certo, se admitirmos a tese de que nossa Constituição é rígida e que o constituinte repartiu, incisivamente, as possibilidades legiferantes entre as entidades dotadas de personalidade política, cuidando para que não houvesse conflitos entre as sub-ordens jurídicas estabelecidas no Estado Federal, a ilação imediata é reconhecer a vedação da delegabilidade, bem como a impossibilidade de renúncia. Que sentido haveria numa discriminação rigorosa de competências, quando se permitisse que uma pessoa delegasse a outra as habilitações recebidas? Em pouco tempo, no manejo das utilizações concretas, quando se manifestasse o direito no dinamismo de seu estudo peculiar, o desenho das atribuições competências passaria por diferentes e imprevisíveis configurações, dissipando a rigidez e a estabilidade pretendidas pelo legislador constituinte. Advém daí o entendimento perante o qual a indelegabilidade e a irrenunciabilidade seriam prerrogativas inafastáveis do exercício da competência, no sistema brasileiro ${ }^{65}$.

(iii) Incaducabilidade - A Constituição Federal não prescreve nenhuma limitação temporal para o exercício da competência tributária. Como exemplo desse atributo, podemos destacar o imposto sobre grandes fortunas, previsto no artigo 153, VII, da Constituição Federal, que até o presente momento não foi criado.

(iv) Inalterabilidade - Com relação a esse atributo, não existem dúvidas sobre a possibilidade de alteração da competência pelas pessoas políticas. ROQUE ANTÔNIO CARRAZA afirma ser a competência tributária improrrogável, vale dizer, não pode ter as suas dimensões ampliadas pela própria pessoa política que a detém. TÁCIO LACERDA GAMA observa que os enunciados inseridos por lei complementar não alteram a competência tributária, mas estatuem em termos analíticos o que a Constituição dispõe de forma sintética ${ }^{66}$.

(v) Irrenunciabilidade - Este atributo decorre da impossibilidade de alteração da competência tributária ${ }^{67}$. Não se deve confundir a renúncia e o não exercício da

${ }^{65}$ Op. Cit., p. 274.

66 "No que diz respeito à lei complementar, a situação é sensivelmente distinta. Esse veículo introdutor de normas pode inserir enunciados prescritivos para desempenhar uma série ampla de finalidades, quase todas relativas à composição da competência. O art. 146, em seus incisos I, II e III, por exemplo, outorga à lei complementar o papel de regular limitações constitucionais ao poder de tributar; estabelecer critérios para solucionar conflitos de competência e veicular normas gerais em direito tributário. Em outros lugares, a lei complementar surge como veículo dos enunciados que disciplinam a forma como deve se dar o princípio da não cumulatividade no ICMS ou definem as materialidades que podem ser consideradas serviço para o fim de sofrerem a incidência do ISS. Buscando uma referência comum para todas essas funções, observa-se que a lei complementar desempenha o papel de situar em termos analíticos aquilo que a própria Constituição dispôs de forma sintética. Noutras palavras, os enunciados inseridos em lei complementar mantêm com a Constituição um vínculo de complementação e subordinação. Esses enunciados complementares prescrevem o que os de natureza constitucional não estatuem, mas dentro dos limites fixados por estes. Por isso, a lei complementar; a pretexto de desempenhar qualquer das funções referidas acima, não pode modificar os termos da mensagem constitucional tributária" (GAMA, Tácio Lacerda. Competência tributária, fundamentos para uma teoria da nulidade, p. 286).

67 "Falece à pessoa política o direito de decidir, ainda que o faça por meio de lei (quanto mais por meio de decreto, portaria, ato administrativo etc.), que não mais tributará determinado fato, inscrito em sua esfera de competência tributária. Exemplificando, é interdito à União abrir mão da competência que recebeu da Carta Suprema (art. 153, I) para tributar a importação de produtos estrangeiros. Acaso assim procedesse, estaria 
competência tributária, como observa TÁCIO LACERDA GAMA, para quem “[...] uma coisa é, por decisão própria, alterar os termos da competência, abrindo mão da faculdade de, posteriormente, editar normas. Outra, bem distinta, é exercer o direito de não exercitar a tal competência, não criando norma"68.

(vi) Facultatividade - Com relação a este atributo, as posições doutrinárias são divergentes. Por um lado, ROQUE ANTÔNIO CARRAZA defende que as pessoas políticas são livres para dispor da competência ${ }^{69}$. Já na visão de PAULO DE BARROS CARVALHO, com a qual afiliamos, a facultatividade não é atributo da competência, eis que a instituição do ICMS pelos Estados e Distrito Federal é obrigatória, nos termos do artigo $155, \S 2^{\circ}$, XII, 'g', ${ }^{70}$ da Constituição Federal:

\footnotetext{
Torna-se necessário lembrar que a competência tributária é exercida por meio de lei (ordinária ou, excepcionalmente, complementar) e ela é, de modo geral, facultativa, vale dizer, o ente público é livre para instituir o tributo que lhe foi conferido pela Lei Maior. A única exceção a esse característico traço do exercício da competência refere-se ao ICMS, pois que, pelas próprias regras, os Estados e o Distrito Federal estão obrigados a implantar e a arrecadar a exação, em decorrência do que dispõe o art. 155, da Lei Suprema:

(...)

Por esse modo, é forçosa a ilação de que os Estados e o Distrito Federal não podem deixar de obedecer, direta ou indiretamente, à letra constitucional, tal como inserida na alínea g, do artigo 155 , cabendo-lhes produzir a legislação correspondente ao gravame ${ }^{71}$.
}

Referida lei é a Lei Complementar $n^{\circ}$ 24/75, recepcionada pela Constituição Federal, que dispõe sobre a temática das isenções e quaisquer outros incentivos ou benefícios, totais ou parciais, concedidos com base no ICMS.

Nota-se, destarte, que a facultatividade não configura um traço inafastável da competência tributária.

afrontando a vontade da Constituição, que, como predica a Teoria Geral do Direito, é estabelecida pelo poder constituinte" (CARRAZA, Roque Antônio. Curso de Direito Constitucional Tributário, p. 696).

68 GAMA, Tácio Lacerda. Op. Cit., p. 287.

69 "As pessoas políticas, conquanto não possam delegar suas competências tributárias, por força da própria rigidez de nosso sistema constitucional, são livres para delas se utilizarem ou não" (CARRAZA, Roque Antônio, Op. Cit, p. 697).

70 "Art. 155

$\S 2^{\circ}$ será não cumulativo, compensando-se o que for devido em cada operação relativa à circulação de mercadorias ou prestação de serviços com o montante cobrado nas anteriores pelo mesmo ou outro Estado ou pelo Distrito Federal;

(...)

XII - cabe à lei complementar:

(...)

g) regular a forma como, mediante deliberação dos Estados e do Distrito Federal, isenções, incentivos e benefícios fiscais serão concedidos e revogados."

${ }^{71}$ CARVALHO, Paulo de Barros. Direito Tributário, linguagem e método, p. 250. 


\subsection{A lei complementar e o papel das normas gerais em matéria tributária}

O sistema constitucional atribui importante papel à lei complementar em matéria tributária. Segundo prescreve o artigo 146, cabe a ela:

I - dispor sobre conflitos de competência, em matéria tributária, entre a União, os Estados, o Distrito Federal e os Municípios;

II - regular as limitações constitucionais ao poder de tributar;

III - estabelecer normas gerais em matéria de legislação tributária, especialmente sobre:

a) definição de tributos e de suas espécies, bem como, em relação aos impostos discriminados nesta Constituição, a dos respectivos fatos geradores, bases de cálculo e contribuintes;

b) obrigação, lançamento, crédito, prescrição e decadência tributários;

c) adequado tratamento tributário ao ato cooperativo praticado pelas sociedades cooperativas.

d) definição de tratamento diferenciado e favorecido para as microempresas e para as empresas de pequeno porte, inclusive regimes especiais ou simplificados no caso do imposto previsto no art. 155, II, das contribuições previstas no art. 195, I e $\S \S 12$ e 13, e da contribuição a que se refere o art. 239. (Incluído pela Emenda Constitucional $n^{\circ} 42$, de 19.12.2003.)

O processo de positivação das normas referentes aos impostos exige, entre a norma de competência constitucional e a norma instituidora do tributo, normas gerais, que devem ser veiculadas por lei complementar para dispor sobre a definição dos fatos geradores (hipótese de incidência com os respectivos critérios material, espacial e temporal), base de cálculo, contribuintes (inciso III alínea "a”), além do sujeito ativo e responsáveis (em razão da obrigação, contido no inciso III, alínea "b").

No tocante ao papel das normas gerais em matéria tributária, divide-se a doutrina em duas correntes definidas: a tricotômica e a dicotômica. Para os defensores da primeira corrente, as normas gerais de direito tributário não se confundem com a regulação de conflitos de competência entre os entes tributantes e as limitações constitucionais ao poder de tributar.

Já para a corrente dicotômica, defendida por PAULO DE BARROS CARVALHO, a lei complementar, ao estabelecer as normas gerais em matéria tributária, deve fazê-lo com dois objetivos distintos: dirimir os conflitos de competência tributária entre os entes políticos e regular as limitações ao poder de tributar, em razão dos primados da federação e da autonomia municipal.

Compartilha do mesmo entendimento ROQUE ANTÔNIO CARRAZA, para quem 
[...] só será válida a lei complementar que vier a dispor sobre conflitos de competência tributária ou a regular limitações constitucionais ao poder de tributar. Tal conclusão, posto que não deflua naturalmente da mera leitura do invocado art. 146, é a única possível se levarmos em conta, em sua exegese, dentre outros, os precitados princípios federativo, da autonomia municipal e da autonomia distrital ${ }^{72}$.

Segundo a posição adotada pelo Professor ${ }^{73}$, a Constituição Federal outorgou as competências tributárias aos entes federativos, e prescreveu, ao mesmo tempo, as fronteiras para o exercício dessa aptidão, ou seja, as "limitações constitucionais ao poder de tributar" nos seus artigos 150, 151 e 152. São dois lados da mesma moeda, de modo que o tratamento jurídico dispensado a uma aproveita à outra.

Dessa forma, o Professor afirma que os possíveis conflitos de competência entre os entes federativos já estão resolvidos na própria Constituição, cabendo à lei complementar o papel de apenas retirar a incerteza quanto ao aparente conflito existente ${ }^{74}$.

Assim, ao "dispor sobre conflitos de competência", a lei complementar busca, por meio de regras gerais, evitar conflitos entre os entes federativos, e não dirimi-los, que é função do Poder Judiciário.

As limitações ao poder de tributar também já estão contempladas na Constituição. Dessa forma, não cabe à lei complementar ampliar ou restringir tais limitações, mas apenas regulá-las, nos lindes já delineados pela Carta Maior.

Com base nessas premissas, ROQUE ANTÔNIO CARRAZA afirma que as normas gerais em matéria tributária possuem caráter meramente declaratório:

\footnotetext{
Daí entendermos que as normas gerais em matéria de legislação tributária, referidas no art. 146 da Lei Maior, têm caráter meramente declaratório. Em outros termos, elas visam a retirar da incerteza aparentes conflitos de competência tributária entre as pessoas políticas. Por igual modo, pretendem reafirmar as "limitações constitucionais ao poder de tributar", que vêm contidas em regras proibitivas, isto é, em mandamentos autoaplicáveis, que, por si mesmos, prescindem de integração legal ou infralegal para terem condições de operatividade $^{75}$.
}

Assim, as normas gerais em matéria tributária introduzidas no ordenamento por meio de lei complementar têm a função de explicitar os comandos constitucionais tributários, definindo os "fatos geradores" (critérios material, espacial e temporal), base de cálculo (critério quantitativo) e contribuintes (critério subjetivo) dos impostos com o

\footnotetext{
${ }^{72}$ CARRAZA, Roque Antônio. Curso de Direito Constitucional Tributário, p. 967.

${ }^{73}$ Ibid., p. 996.

${ }^{74}$ Ibid., p. 997.

${ }^{75}$ Ibid., p. 997.
} 
propósito exclusivo de evitar conflitos de competência e regular a limitação do poder de tributar dos entes federativos competentes à sua instituição.

As normas gerais também contribuem na formação do arquétipo normativo relativo ao lançamento, crédito, prescrição e decadência (inciso III alínea "b"), além das demais funções prescritas nas alíneas "c" e "d". 


\section{CAPÍTULO II: O ICMS MERCANTIL}

\subsection{Perfil constitucional do ICMS}

Nos termos do artigo 155, inciso II, da Constituição da República, compete aos Estados e ao Distrito Federal instituir impostos sobre "operações relativas à circulação de mercadorias e sobre prestações de serviços de transporte interestadual e intermunicipal e de comunicação, ainda que as operações e as prestações se iniciem no exterior".

Portanto, o ICMS é um imposto de competência dos Estados-membros e do Distrito Federal, que podem, mediante lei ordinária, instituí-lo ou sobre ele dispor. O Professor ROQUE ANTÔNIO CARRAZA ${ }^{76}$ ressalta que a União também desfruta da competência para instituir esses impostos nas situações excepcionais contempladas nos artigos $147^{77} \mathrm{e}$ 154, II, da Constituição Federal, quais sejam, na criação dos Territórios Federais ou "na iminência ou no caso de guerra externa".

A Lei Complementar $n^{\circ} \quad 87 / 96$ possui função de extrema relevância na regulamentação do ICMS, eis que deu cumprimento ao disposto no artigo $155, \S 2^{\circ}$, XII, da Constituição Federal, especificando suas hipóteses de incidência e de não incidência, os contribuintes, os casos de substituição tributária, além de fornecer os elementos para a determinação da base de cálculo, dentre outros aspectos, deixando a definição da alíquota para os Estados-membros, respeitados os limites definidos pelo Senado Federal.

A referida lei complementar prescreve as seguintes materialidades:

Art. $2^{\circ} \mathrm{O}$ imposto incide sobre:

I - operações relativas à circulação de mercadorias, inclusive o fornecimento de alimentação e bebidas em bares, restaurantes e estabelecimentos similares;

II - prestações de serviços de transporte interestadual e intermunicipal, por qualquer via, de pessoas, bens, mercadorias ou valores;

III - prestações onerosas de serviços de comunicação, por qualquer meio, inclusive a geração, a emissão, a recepção, a transmissão, a retransmissão, a repetição e a ampliação de comunicação de qualquer natureza;

IV - fornecimento de mercadorias com prestação de serviços não compreendidos na competência tributária dos Municípios;

$\mathrm{V}$ - fornecimento de mercadorias com prestação de serviços sujeitos ao imposto sobre serviços, de competência dos Municípios, quando a lei complementar aplicável expressamente o sujeitar à incidência do imposto estadual.

${ }^{76}$ CARRAZA, Roque Antônio. ICMS. 16 ${ }^{\mathrm{a}}$ ed. São Paulo: Malheiros, 2012. p 40.

77 “Art. 147: Competem à União, em Território Federal, os impostos estaduais e, se o Território não for dividido em Municípios, cumulativamente, os impostos municipais.

Art. 154: A União poderá instituir: (...) II - na iminência de guerra externa, impostos extraordinários, compreendidos ou não em sua competência tributária, os quais serão suprimidos, gradativamente, cessadas as causas de sua criação. 
De acordo com o parágrafo $1^{\circ}$ do artigo supramencionado, o ICMS também incidirá:

I - sobre a entrada de mercadoria ou bem importados do exterior, por pessoa física ou jurídica, ainda que não seja contribuinte habitual do imposto, qualquer que seja a sua finalidade;

II - sobre o serviço prestado no exterior ou cuja prestação se tenha iniciado no exterior;

III - sobre a entrada, no território do Estado destinatário, de petróleo, inclusive lubrificantes e combustíveis líquidos e gasosos dele derivados, e de energia elétrica, quando não destinados à comercialização ou à industrialização, decorrentes de operações interestaduais, cabendo o imposto ao Estado onde estiver localizado o adquirente.

Analisando as materialidades acima relacionadas, ROQUE ANTÔNIO CARRAZA identifica a existência de diferentes hipóteses de incidência e bases de cálculo do ICMS, levando-o a concluir pela existência de pelo menos cinco impostos diferentes. Confira-se:

\begin{abstract}
A sigla ICMS alberga pelo menos cinco impostos diferentes; a saber: a) o imposto sobre operações mercantis (operações sobre a circulação de mercadorias), que, de algum modo, compreende o que nasce da entrada de mercadorias importadas do exterior; b) o imposto sobre serviços de transporte interestadual e intermunicipal; c) o imposto sobre serviços de comunicação; d) o imposto sobre produção, importação, circulação, distribuição ou consumo de lubrificantes e combustíveis líquidos e gasosos e de energia elétrica; e, e) o imposto sobre extração, circulação, distribuição ou consumo de minerais. Dizemos diferentes, porque estes tributos têm hipótese de incidência e bases de cálculo diferentes. Há, pois, pelo menos cinco núcleos distintos de incidência de $\operatorname{ICMS}^{78}$.
\end{abstract}

Já PAULO DE BARROS CARVALHO identifica, a partir da análise dos antecedentes normativos, três regras-matrizes desse imposto:

No caso do ICMS, temos três regras-matrizes, o que implica admitir que existem três hipóteses de incidência e três consequências. Vejamos os três antecedentes normativos que a legislação constitucional consagra para, em seguida, tratarmos dos consequentes:

a) realizar operações relativas à circulação de mercadorias;

b) prestar serviços de comunicação, mesmo que se iniciem no exterior, prestações essas que deverão concluir-se ou ter início dentro dos limites territoriais dos estados e do distrito federal, identificadas as prestações no instante da execução, da geração ou da utilização dos serviços correspondentes;

c) prestar serviços de transporte interestadual e intermunicipal $^{79}$.

No que se refere à competência para instituir o ICMS, verifica-se no Texto Constitucional que o Constituinte houve por bem estabelecer limites rígidos a serem

${ }^{78}$ CARRAZA, Roque Antônio. ICMS, p. 41.

${ }^{79}$ CARVALHO, Paulo de Barros. Direito Tributário, linguagem e método, p. 727. 
observados pelos Estados e o Distrito Federal, a fim de que o aludido imposto não se transforme em verdadeiro instrumento de guerra fiscal.

Nesse diapasão, destaca-se, inicialmente, o princípio da não cumulatividade, previsto no artigo 155, inciso I, parágrafo $2^{\circ}$, incisos I e II, da Constituição Federal, que assegura ao contribuinte o direito de abatimento do ICMS que incidiu nas operações ou prestações de serviços anteriores com o imposto devido nas operações ou prestações de serviços realizados pelo sujeito passivo do imposto.

A não cumulatividade do ICMS - assunto que será abordado em tópico próprio - é aplicável a todas as hipóteses de incidência que esse imposto contempla. Nos dizeres de ROQUE ANTÔNIO CARRAZA, é o "núcleo central comum" ${ }^{80}$ dos critérios materiais sujeitos à incidência desse imposto.

Apesar de esse princípio resultar na desoneração da cadeia tributária, o Constituinte criou exceções, dispondo que as operações isentas ou não sujeitas à incidência desse imposto, prescritas no inciso II, do $\S 2^{\circ}$ do artigo $155^{81}$ da Carta Maior, não gerarão crédito para compensação nas operações subsequentes e culminarão na anulação do crédito na entrada.

Noutras palavras, a mercadoria adquirida em operação isenta ou imune não autorizará o creditamento do imposto pelo adquirente desse bem (alínea "a", do inciso II, do $\S 2^{\circ}$ do artigo 155) e, ainda, acarretará a anulação do crédito da entrada pelo vendedor da mercadoria (alínea "b" do referido enunciado constitucional).

Além da não cumulatividade, o legislador constituinte prescreveu que o ICMS "poderá ser seletivo, em função da essencialidade das mercadorias e dos serviços" (artigo 155, inciso III, parágrafo $2^{\circ}$ da Carta Maior). A seletividade também é aplicada ao IPI, conforme o artigo 153, inciso I, parágrafo $3^{\circ}$, da Constituição de 1988, o qual prescreve que o imposto "será seletivo, em função da essencialidade do produto".

A seletividade está intimamente relacionada à essencialidade do produto tributado, de modo que, quanto maior a sua relevância para o consumo (mercadorias que compõem a cesta básica) menor deverá ser a tributação por esse imposto. Sobre a seletividade, JOSÉ AFONSO DA SILVA explica que:

${ }^{80}$ CARRAZA, Roque Antônio. ICMS, p. 41.

81 “Art. 155 (...)

$\S 2^{\circ}$. O imposto previsto no inciso II atenderá o seguinte:

(...)

II - a isenção ou não-incidência, salvo determinação em contrario da legislação:

a) não implicará crédito para compensação com o montante devido nas operações ou prestações seguintes;

b) acarretará a anulação do credito relativo às operações anteriores. 
É uma regra política fiscal com conteúdo socioeconômico importante, porque obriga o estabelecimento de alíquotas diversas para os produtos tributados, como permite isentar algumas à vista de motivos sociais ou econômicos. $\mathrm{O}$ grau de essencialidade de certos produtos pode variar segundo circunstâncias concretas, mas pode-se a priori determinar que certos produtos serão essenciais à vida, como a alimentação e o vestuário, enquanto outros são essenciais ao desenvolvimento do país; e há aqueles que são apenas úteis e os que são supérfluos. A alíquota do imposto deve variar segundo o grau de essencialidade dos produtos, a fim de atender aos reclamos da justiça social e ao processo de industrialização e desenvolvimento econômico ${ }^{82}$.

O princípio da seletividade, aplicável tanto ao ICMS como ao IPI, suscita indagações acerca da sua obrigatoriedade ou facultatividade no que tange ao primeiro imposto. Isso porque o legislador constituinte empregou a expressão "poderá ser seletivo" ao se referir ao ICMS e "será seletivo" em relação ao IPI.

JOSÉ EDUARDO SOARES DE MELLO ${ }^{83}$ entende que a seletividade é facultativa para o ICMS, não podendo ser utilizada, contudo, como mero critério de conveniência e oportunidade. No nosso entendimento, como o ICMS é um tributo extrafiscal, que estimula ou desestimula a prática de operações ou prestações úteis à sociedade, entendemos que a seletividade é obrigatória para este imposto, como bem acentuou ROQUE ANTÔNIO CARRAZA:

\footnotetext{
O atual ICMS, pelo contrário, deve ser um instrumento de extrafiscalidade, porquanto a teor do art. $155, \S 2^{\circ}$, III, da CF, "poderá ser seletivo, em função da essencialidade das mercadorias e dos serviços".

Antes de avançarmos em nosso raciocínio, vamos logo consignando que este singelo 'poderá' equivale juridicamente a um peremptório 'deverá'. Não se está, aqui, diante de mera faculdade do legislador, mas de norma cogente - de observância, pois, obrigatória.

Além disso, quando a Constituição confere a uma pessoa política um 'poder', ela, ispo facto, está lhe impondo um 'dever'. É por isso que se costuma falar que as pessoas políticas têm poderes-deveres (ou, como mais apropriadamente proclama Celso Antônio Bandeira de Mello, deveres-poderes) ${ }^{84}$.
}

Apesar de o princípio da essencialidade ser, a nosso ver, de observância obrigatória, percebe-se o desrespeito desse princípio por parte do legislador do Estado de São Paulo, que tributa a energia elétrica, produto de primeira necessidade, à alíquota de até $25 \%$, conforme prescreve o inciso $\mathrm{V}$ do artigo 52 do RICMS $/ 00^{85}$.

\footnotetext{
${ }^{82}$ SILVA, José Afonso. Comentário contextual à Constituição. $3^{\mathrm{a}}$ ed. São Paulo. Malheiros, 2007. p. 665.

${ }^{83}$ MELLO, José Eduardo Soares. ICMS. Teoria e Prática. 12 $2^{\mathrm{a}}$ ed. 2012. São Paulo: Dialética. p. 360.

${ }^{84}$ CARRAZA, Roque Antônio. ICMS, p. 507.

85 “Artigo 52 - As alíquotas do imposto, salvo exceções previstas nos artigos 53, 54, 55 e 56-B, são:

(...)

V - Nas operações com energia elétrica, no que respeita aos fornecimentos adiante indicados:
} 
Prosseguindo a análise dos enunciados constitucionais relativos ao ICMS, o artigo 155, parágrafo $2^{\circ}$, inciso IV, da Constituição Federal, estabelece uma limitação à competência estadual para a fixação de alíquotas. No que se refere às alíquotas aplicáveis às operações e prestações interestaduais e de exportação, estas poderão apenas ser fixadas por resolução do Senado Federal, de iniciativa do Presidente da República ou de um terço dos senadores, aprovada pela maioria absoluta de seus membros.

Outrossim, o artigo $155, \S 2^{\circ}$, inciso V, da Constituição Federal estabelece que

[...] é facultado ao Senado Federal: a) estabelecer alíquotas mínimas nas operações internas, mediante resolução da iniciativa de um terço e aprovada pela maioria absoluta de seus membros; b) fixar alíquotas máximas nas mesmas operações para resolver conflito específico que envolva interesse de Estados, mediante resolução de iniciativa da maioria absoluta e aprovada por dois terços de seus membros(...).

No que tange às operações e prestações interestaduais, a Constituição Federal, em seu artigo 155, $\S 2^{\circ}$, estabelece: salvo deliberação em contrário dos Estados e do Distrito Federal, nos termos do disposto no inciso XII, "g", as alíquotas internas, nas operações relativas à circulação de mercadorias e nas prestações de serviços, não poderão ser inferiores às previstas para as operações interestaduais (inciso VI); em relação às operações e prestações que destinem bens e serviços ao consumidor final localizado em outro Estado, adotar-se-á: a) a alíquota interestadual, quando o destinatário for contribuinte do imposto; b) a alíquota interna, quando o destinatário não for contribuinte dele (inciso VII); na hipótese da alínea "a" do inciso anterior, caberá ao Estado da localização do destinatário o imposto correspondente à diferença entre a alíquota interna e a interestadual (inciso VIII).

A Constituição Federal estabelece, ainda, a imunidade (i) com relação à exportação de mercadorias e serviços, sem prejuízo do aproveitamento do crédito decorrente do imposto cobrado nas operações e prestações anteriores (artigo 155, $\S 2^{\circ}$, inciso X, alínea “a”); (ii) sobre operações que destinem a outros Estados petróleo, inclusive lubrificantes, combustíveis líquidos e gasosos dele derivados, e energia elétrica (artigo 155, §2º inciso X, alínea "b"); (iii) em relação ao ouro-ativo financeiro (artigo 155, §2º inciso X, alínea

a) $12 \%$ (doze por cento), em relação à conta residencial que apresentar consumo mensal de até 200 (duzentos) $\mathrm{kWh}$

b) $25 \%$ (vinte e cinco por cento), em relação à conta residencial que apresentar consumo mensal acima de 200 (duzentos) kWh;

c) $12 \%$ (doze por cento), quando utilizada no transporte público eletrificado de passageiros;

d) $12 \%$ (doze por cento), nas operações com energia elétrica utilizada em propriedade rural, assim considerada a que efetivamente mantiver exploração agrícola ou pastoril e estiver inscrita no Cadastro de Contribuintes do ICMS.” 
“c”) e (iv) nas prestações de serviços de comunicação nas modalidades de radiodifusão sonora e de sons e imagens de recepção livre a gratuita (artigo $155, \S 2^{\circ}, \mathrm{X}, \mathrm{d}$ ).

\subsection{Regra-matriz constitucional do ICMS mercantil}

Para o objetivo pretendido no presente trabalho, interessa-nos analisar a incidência do ICMS apenas sobre operações mercantis, razão pela qual se faz necessário construir a seguinte norma-padrão deste imposto, conforme o artigo 155, inciso II, da Constituição da República $^{86}$.

Hipótese:

$>$ critério material: realizar operação relativa à circulação de mercadoria;

> critério espacial: âmbito territorial do Estado ou do Distrito Federal;

$>$ critério temporal: momento da saída da mercadoria.

Consequência:

critério pessoal: sujeito ativo - Estado ou Distrito Federal; sujeito passivo - o comerciante que praticou a operação relativa à circulação de mercadoria;

> critério quantitativo: base de cálculo - valor da operação de circulação de mercadoria; alíquota - aquela prevista na legislação do imposto, oscilando de acordo com a circunstância de ser operação interna ou interestadual.

Passamos a analisar detalhadamente cada um dos critérios acima expostos:

\subsubsection{Critério material do ICMS}

Conforme já demonstrado, o critério material é um proceder humano, linguisticamente representado por um verbo pessoal de predicação incompleta, que deve estar no infinitivo, e o seu complemento.

No tocante ao ICMS que dispomos a analisar, o seu critério material é: realizar operações relativas à circulação de mercadorias.

\footnotetext{
86 “Art. 155 - Compete aos Estados e ao Distrito Federal instituir impostos sobre:

II - operações relativas à circulação de mercadorias e sobre prestações de serviços de transporte interestadual e intermunicipal e de comunicação, ainda que as operações e as prestações se iniciem no exterior (...)."
} 
Para a devida compreensão do critério material do ICMS, previsto no artigo 155 , inciso II, da Carta Maior, torna-se imprescindível a investigação semântica dos termos “operações" "circulação" e "mercadoria".

Nesse sentido, destaque-se o valioso magistério de PAULO DE BARROS CARVALHO:

\begin{abstract}
"Operações", "circulação" e "mercadorias" são três elementos essenciais para a caracterização da venda de mercadorias. Tenho para mim que o vocábulo "operações", no contexto, exprime o sentido de atos ou negócios jurídicos hábeis para provocar a circulação de mercadorias. "Circulação", por sua vez, é a passagem das mercadorias de uma pessoa para outra, sob o manto de um título jurídico, com a consequente mudança de patrimônio. Já o adjunto adnominal "de mercadorias" indica que nem toda a circulação está abrangida no tipo proposto, mas unicamente aquelas que envolvam mercadorias ${ }^{87}$.
\end{abstract}

GERALDO ATALIBA e CLEBER GIARDINO atribuíram ao termo operações a significação de "atos jurídicos; atos regulados pelo Direito como produtores de determinada eficácia jurídica; atos juridicamente relevantes." 88

Deve-se ressaltar que, para efeitos de incidência do ICMS mercantil, são relevantes somente os atos jurídicos qualificados como negócios jurídicos, que têm como marco fundamental o caráter econômico e diferem dos demais atos que não se caracterizam pela patrimonialidade, como bem ressaltou ELIUD JOSÉ PINTO DA COSTA ${ }^{89}$ ao tratar especificamente sobre esse imposto.

Portanto, o legislador constituinte elegeu as operações, compreendida como o negócio jurídico mercantil, como o núcleo da hipótese de incidência do ICMS mercantil.

A relevância do termo "operações” em relação aos demais componentes do critério material foi destacada por GERALDO ATALIBA, para quem

[...] a circulação e a mercadoria são consequências e meros aspectos adjetivos da operação tributada. Prestam-se, tão só a qualificar - dentro do universo possível das operações mercantis realizáveis - aquelas que ficam sujeitas ao tributo, ex vi de uma eficaz qualificação legislativa. Não é qualquer operação realizada que se sujeita ao ICMS. Destas, apenas poderão ser tributadas as que digam respeito à circulação atinente a uma especial categoria de bem: as mercadorias ${ }^{90}$.

\footnotetext{
${ }^{87}$ CARVALHO, Paulo de Barros. Direito Tributário, linguagem e método, p. 381.

${ }^{88}$ ATALIBA, Geraldo; GIARDINO, Cleber. Núcleo da definição constitucional do ICM. Revista de Direito Tributário. 7. ed. São Paulo, v. 25-26, 2004, p. 105.

${ }^{89}$ COSTA, Eliud José Pinto. ICMS mercantil. São Paulo: Quartier Latin, 2008. p. 88.

${ }^{90}$ ATALIBA, Geraldo. Incorporação ao ativo - Empresa que loca, oferece em "leasing" seus produtos Descabimento do ICMS. Revista de Direito Tributário. São Paulo, vol. 52. p.74.
} 
Para PAULO DE BARROS CARVALHO, o termo "operações com circulação de mercadorias" tem o significado de "transferência de titularidade". De acordo com os ensinamentos do Professor, para fins de exigência do ICMS, é imprescindível a ocorrência de negócios jurídicos como "atos jurídicos que promovem a transmissão de direito, in casu, a propriedade de mercadorias." ${ }^{91}$. Na mesma linha, ROQUE ANTÔNIO CARRAZA afirma:

[...] a operação relativa à circulação de mercadorias só pode ser jurídica e não meramente física, o que, evidentemente, pressupõe a transferência, de uma pessoa a outra e pelos meios adequados, da titularidade de uma mercadoria vale dizer, dos poderes de disponibilidade sobre ela ${ }^{92}$.

Portanto, não é sobre qualquer operação que incide o ICMS, mas somente sobre aquelas que resultam na transferência de titularidade de mercadorias (circulação jurídica), a qual não se confunde com circulação física ou econômica.

Ao discorrer sobre a circulação física, ELIUD JOSÉ PINTO DA COSTA ${ }^{93}$ afirma que esse ballet de mercadorias tem pouquíssima importância, porque não conduz ao cumprimento de obrigação tributária principal, mas apenas acessória (dever instrumental), como a emissão de notas fiscais. Nesse diapasão, a Súmula 573 do Supremo Tribunal Federal estabelece que "não se constitui fato gerador do ICM (ICMS) a saída física de máquinas, utensílios e implementos a título de comodato".

Quanto à circulação econômica, ELIUD JOSÉ PINTO DA COSTA a define como "a mudança de estágios econômicos que se originam na produção e se atravessam várias etapas, como a industrialização, distribuição e consumo". Segundo o autor, não há possibilidade de tributação pelo ICMS quando determinada empresa produz um bem e o incorpora ao seu ativo imobilizado ou utiliza-o para locação. Isso porque, apesar da ocorrência de circulação econômica, o bem, no primeiro caso, não pode ser qualificado como mercadoria, e a locação, no segundo caso, não conduz à transferência de propriedade $^{94}$.

Por fim, cumpre atribuir significação ao termo "mercadoria" empregado pelo legislador constituinte. Deveras, a repartição de competências tributárias tem caráter conceitual e não tipológica (aberto, flexível), delimitando, desta forma, o espetro de atuação legislativa dos entes políticos na instituição de tributos.

\footnotetext{
${ }^{91}$ CARVALHO, Paulo de Barros. Direito Tributário, linguagem e método, p. 729.

${ }^{92}$ CARRAZA, Roque Antônio. ICMS, p. 43.

${ }^{93}$ COSTA, Eliud José Pinto. ICMS mercantil, p. 106.

${ }^{94}$ Ibid., p. 107/108.
} 
Os signos constitucionais, que qualificam os limites do exercício da competência tributária, devem ser considerados de acordo com a sua acepção de base, devendo, portanto, prevalecer seu sentido técnico-jurídico preexistente.

Em estudo sobre conceitos e competências tributárias, ANDREI PITTEN VELOSO propõe a segregação dos conceitos constitucionais em recepcionados e autônomos. De acordo com o autor,

[...] não se presume o acolhimento de conceitos autônomos. Pelo contrário, devese fundamentá-lo adequadamente, de forma a preterir a regra prima facie de incorporação dos conceitos preexistentes, que é assentada na "regra do uso comum" e impõe ao intérprete trabalhar inicialmente com a hipótese de que a Constituição não se afastou das convenções linguísticas preexistentes, sujeitando-a à confirmação sistemática ${ }^{95}$.

Assim, diante de um signo constitucional, compete ao intérprete verificar a sua recepção com base na acepção jurídica preexistente ou se ocorreu alteração, isto é, a positivação do conceito autônomo.

Assim, quando a Constituição Federal se refere a "mercadorias”, ela está adotando a sua significação preexistente no Direito Privado, segundo o qual mercadoria é aquele bem móvel, que o comerciante, em razão da prática habitual da mercancia, utiliza para a venda com o fito de lucro.

Corroborando o acima exposto, ROQUE ANTÔNIO CARRAZA pondera que

[...] não é qualquer móvel que é mercadoria, mas só aquele que submete a mercancia. Podemos, pois dizer que toda mercadoria é bem móvel, mas nem todo bem móvel é mercadoria. Só o bem móvel que se destina a prática de operações mercantis é que assume a qualidade de mercadoria ${ }^{96}$.

Portanto, o traço característico da mercadoria é a sua destinação mercantil, sendo irrelevantes as suas propriedades intrínsecas, como observa PAULO DE BARROS CARVALHO, que fornece o seguinte exemplo:

É mercadoria a caneta exposta à venda entre outras adquiridas para esse fim. Não se enquadra nesse conceito, porém, aquela mantida em meu bolso e destinada a meu uso pessoal. Observe-se que não se operou a menor modificação na índole do objeto referido. Apenas sua destinação veio a conferir-lhe atributo de mercadoria $^{97}$.

\footnotetext{
${ }^{95}$ VELOSO, Andrei Piten. Conceitos e competências tributárias. São Paulo: Dialética, 2005. p. 131.

${ }^{96}$ CARRAZA, Roque Antônio. ICMS, p. 41.

${ }^{97}$ CARVALHO, Paulo de Barros. Direito Tributário, linguagem e método, p. 730.
} 
Assim, um bem móvel é considerado mercadoria desde que tenha por finalidade a venda ou revenda. Essa qualidade extrínseca é a que distingue o bem móvel (gênero) da mercadoria (espécie). Nesse sentido, ROQUE ANTÔNIO CARRAZA, exemplifica:

[...] um bem de uso próprio (v.g., geladeira) não é mercadoria. Quando vendido, a terceiro, por seu proprietário, não faz nascer a obrigação de pagar ICMS. (...) Situação diversa ocorre quando a geladeira é comprada e revendida por uma loja de eletrodomésticos. Aí, sim, ocorre a operação mercantil, ensejando a tributação por meio do $\mathrm{ICMS}^{98}$.

Logo, o critério material do ICMS, previsto constitucionalmente, consiste na operação mercantil (negócios jurídicos) que acarrete circulação jurídica (transferência de titularidade) de mercadoria (bem móvel sujeito a mercancia).

\subsubsection{Critério temporal do ICMS}

O critério temporal do ICMS mercantil não está enunciado expressamente na Constituição Federal. Esse papel coube ao legislador complementar, por determinação do artigo 146, III, alínea "a", da Carta Maior, que o elegeu como o momento da saída da mercadoria de estabelecimento do contribuinte (artigo 12, I, da Lei Complementar $\mathrm{n}^{\circ}$ 87/96).

Antes de discorrer sobre esse momento, cabe, inicialmente, uma advertência: Como o critério material do ICMS mercantil é a realização de operações relativas à circulação de mercadorias, o critério temporal deve necessariamente exteriorizar esse momento. Nesse sentido, PAULO DE BARROS CARVALHO assevera que nos caso de a materialidade realizar operações com circulação de mercadorias,

[...] qualquer fato que dissesse respeito à operação, à circulação ou às mercadorias, evidentemente que considerados na integração racional do núcleo da hipótese (...) estaria capacitado a exteriorizar o evento, marcando o nascer de uma obrigação tributária ${ }^{99}$.

Passamos a discorrer sobre o momento prescrito pela Lei Complementar $n^{\circ}$ 87/96: a saída da mercadoria do estabelecimento do contribuinte, que não é a hipótese de incidência do ICMS mercantil. Se assim fosse, ROQUE ANTÔNIO CARRAZA ${ }^{100}$ afirma que as

\footnotetext{
${ }^{98}$ CARRAZA, Roque Antônio. ICMS, p. 49.

${ }^{99}$ CARVALHO, Paulo de Barros. Regra Matriz do ICM, p. 255.

${ }^{100}$ CARRAZA, Roque Antônio. Op. Cit., p. 53.
} 
mercadorias levadas para fora do estabelecimento comercial por força das águas de inundação ensejariam a incidência do ICMS.

Assim, a mera saída física da mercadoria sem a transferência da sua titularidade não configura uma operação relativa à circulação de mercadorias. Nos dizeres do Professor acima citado ${ }^{101}$ não se pode reputar como ocorrido o fato jurídico a) em momento anterior à ocorrência da operação mercantil; b) quando o fato verificado não configura operação mercantil; c) quando o bem móvel sai do estabelecimento comercial, industrial ou produtor para a ele tornar, como se dá no comodato, ou d) na consignação mercantil, em que o consignante remete mercadoria de sua propriedade para o consignatário, que a vendera, por sua conta e risco.

JOSÉ EDUARDO SOARES DE MELLO afirma ser irrelevante perquirir-se sobre as movimentações físicas ocorridas antes da saída da mercadoria (critério temporal), entendida como "a circulação pela via pública, estranha aos limites físicos do estabelecimento do contribuinte" 102 .

\subsubsection{Critério espacial do ICMS}

A Constituição Federal, em seu artigo 155, §2 , XII, “d”103, prescreve que o local das operações relativas à circulação de mercadorias e das prestações de serviços deve ser fixado por lei complementar.

Em observância ao mandamento constitucional, a Lei Complementar $n^{\circ} 87 / 96$ elegeu como local onde se reputa ocorrido o fato jurídico tributário (critério espacial), nas operações mercantis realizadas com mercadorias ${ }^{104}$, o estabelecimento. Dessa forma, devemos verificar qual a definição desse conceito.

\footnotetext{
${ }^{101}$ CARRAZA, Roque Antônio. ICMS, p. 53.

102 MELLO, José Eduardo Soares. ICMS, p. 22.

103 “Art. 155

(...)§ $2 .^{\circ} \mathrm{O}$ imposto previsto no inciso II atenderá ao seguinte:

XII - cabe à lei complementar:

d) fixar, para efeito de sua cobrança e definição do estabelecimento responsável, o local das operações relativas à circulação de mercadorias e das prestações de serviços."

104 “Art. 11. O local da operação ou da prestação, para os efeitos de cobrança do imposto e definição do estabelecimento responsável, é:

I - tratando-se de mercadoria ou bem:

a) o do estabelecimento onde se encontre, no momento da ocorrência do fato gerador;

b) onde se encontre, quando em situação irregular pela falta de documentação fiscal ou quando acompanhado de documentação inidônea, como dispuser a legislação tributária;

c) o do estabelecimento que transfira a propriedade, ou o título que a represente, de mercadoria por ele adquirida no País e que por ele não tenha transitado;

d) importado do exterior, o do estabelecimento onde ocorrer a entrada física;
} 
O Código Civil de 2002 considera estabelecimento todo complexo de bens organizado, para exercício da empresa, por empresário, ou por sociedade empresarial.

Da mesma forma, JOSÉ EDUARDO SOARES DE MELLO define o conceito de estabelecimento como "o complexo de bens, materiais ou imateriais, que constituem o instrumento utilizado pelo comerciante para a exploração de determinada atividade mercantil" 105 .

O estabelecimento não é apenas o prédio onde as atividades são realizadas, que pode nem sequer existir, como esclarece ELIUD JOSÉ PINTO DA COSTA:

[...] o estabelecimento não se resume ao prédio onde as atividades são realizadas. O prédio é apenas uma indicação de que naquele local encontram-se outros componentes que integram o estabelecimento da empresa, isto é, os bens que a ela pertencem. O estabelecimento empresarial pode ser dividido em vários prédios distribuídos em locais diversos de uma mesma ou até em cidades diferentes. Nesse sentido, é de presumir-se que a empresa possui filiais.

(...)

O estabelecimento pode, também, não possuir prédio, mas um veículo, uma carroça, um simples tabuleiro; pode não ter endereço fixo, mas ambulante; pode sequer existir no plano físico, mas virtual, com endereço virtual. Apesar disso a empresa será existente e, por via de consequência terá um estabelecimento, nem que seja apenas para identificar seus serviços, sua patente, sua marca, seu nome, seus direitos, suas responsabilidades, etc. ${ }^{106}$

Não obstante a abrangência da definição ao conceito de estabelecimento, o artigo $11, \S 3^{\circ}$, da Lei Complementar $n^{\circ} 87 / 96$ prescreveu o que dever ser entendido como estabelecimento: "o local, privado ou público, edificado ou não, próprio ou de terceiros, onde pessoas físicas ou jurídicas exerçam suas atividades em caráter temporário ou permanente, bem como onde se encontram armazenadas mercadorias".

O inciso I do aludido parágrafo estabelece que "na impossibilidade de determinação do estabelecimento, considera-se como tal o local em que tenha sido efetuada a operação ou prestação, encontrada a mercadoria ou constatada a prestação".

A referida lei complementar prescreve que, em se tratando de operações mercantis, o critério espacial é o local do estabelecimento onde se encontra a mercadoria no instante

e) importado do exterior, o do domicílio do adquirente, quando não estabelecido;

f) aquele onde seja realizada a licitação, no caso de arrematação de mercadoria ou bem importados do exterior e apreendidos ou abandonados (Redação dada pela Lcp 114, de 16.12.2002);

g) o do Estado onde estiver localizado o adquirente, inclusive consumidor final, nas operações interestaduais com energia elétrica e petróleo, lubrificantes e combustíveis dele derivados, quando não destinados à industrialização ou à comercialização;

h) o do Estado de onde o ouro tenha sido extraído, quando não considerado como ativo financeiro ou instrumento cambial;

i) o de desembarque do produto, na hipótese de captura de peixes, crustáceos e moluscos.”

${ }^{105}$ MELLO, José Eduardo Soares. ICMS, p. 25

${ }^{106}$ COSTA, Eliud José Pinto. ICMS mercantil, p. 216. 
em que ocorre o fato jurídico tributário. Os demais critérios especiais do ICMS, contemplados nas alíneas b, c, d, f, g, h, i do artigo 11, não serão abordados neste trabalho, por fugirem do objetivo deste estudo.

\subsubsection{Critério pessoal do ICMS}

\subsubsection{Sujeitos ativo e passivo (contribuintes)}

Os sujeitos ativos do ICMS (titular do direito subjetivo de exigir o cumprimento da obrigação tributária) são os Estados e o Distrito Federal e, de forma excepcional, a União no caso de iminência ou guerra externa ou na eventual criação de territórios (artigos 154, II e 147, da Constituição Federal de 1988).

No tocante ao sujeito passivo do ICMS, a Constituição Federal de 1988 não indicou expressamente, como fez a Constituição pretérita com relação ao antigo ICM, quais são as pessoas que ostentam essa condição, mas delegou ao legislador complementar a tarefa de defini-los.

JOSÉ EDUARDO SOARES DE MELLO também reconhece que o texto constitucional é implícito na eleição dos sujeitos passivos, afirmando que “[...] normalmente, a Constituição não indica a pessoa que deve ser caracterizada como devedora do tributo, mas apenas contempla as materialidades suscetíveis de incidência, outorgando as respectivas competências às pessoas políticas" ${ }^{\text {"107. }}$.

ROQUE ANTÔNIO CARRAZA, apesar de também reconhecer a implicitude constitucional no tocante aos sujeitos passivos, afirma, com esteio no artigo 126 do CTN, que, além das pessoas contempladas na Constituição pretérita (comerciante, industrial ou produtor), a atual Carta Maior prescreve que "o comerciante de fato, o comerciante irregular, um agregado familiar" ${ }^{\prime 108}$ também podem ser alcançados por esse imposto desde que promovam, com habitualidade, operações com circulação de mercadorias.

Em sentido contrário, partilhamos dos ensinamentos de PAULO DE BARROS CARVALHO, para quem o Código Tributário Nacional confunde a capacidade de realizar o fato jurídico com a possibilidade de integrar a obrigação tributária. De acordo com o

\footnotetext{
${ }^{107}$ MELLO, José Eduardo Soares. ICMS, p. 187.

${ }^{108}$ CARRAZA, Roque Antônio. ICMS, p. 45
} 
Professor, os entes sem personalidade jurídica podem realizar o fato jurídico tributário, mas não compõem a relação jurídica tributária ${ }^{109}$.

Logo, para ocupar a posição de sujeito passivo desse imposto, mister será que o legislador infraconstitucional aponte, com precisão, entre as pessoas envolvidas na efetivação do evento, o sujeito de direito que deve responder à prestação do imposto, dotados de personalidade jurídica, que efetivamente realize operações relativas à circulação de mercadorias, isto é, que pratique o fato descrito na hipótese de incidência do imposto estadual.

Nesse sentido, o artigo $4^{\circ}$ da Lei Complementar $n^{\circ} 87 / 96$ indica, de forma conotativa, as propriedades relativas aos contribuintes do ICMS: (i) ser pessoa física ou jurídica; (ii) que realize operações relativas à circulação de mercadorias; (iii) em caráter habitual ou em volume que caracterize intuito comercial.

Com relação à habitualidade, PAULO DE BARROS CARVALHO afirma que esse termo é dotado de vaguidade semântica, por ser “[...] dúbio, ambíguo, esquivo, indefinido, inconsistente, que não dá segurança a quem o emprega, deixando hesitante aquele que o

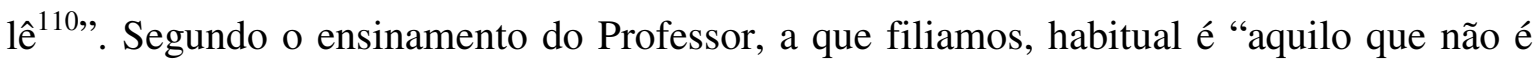
esporádico, anormal, atípico"111.

Portanto, apesar de o legislador complementar não ter elencado, de forma explícita, os contribuintes possíveis do ICMS mercantil como sendo o comerciante, o industrial ou o produtor, é certo que essas pessoas só serão contribuintes do ICMS em questão quando realizarem operações com circulação de mercadorias de forma habitual.

\subsubsection{Responsáveis}

O Código Tributário Nacional estabeleceu as situações de responsabilidade tributária nos seus artigos 121 a 138. Essas relações têm, conforme o escólio de PAULO DE BARROS CARVALHO natureza de sanção administrativa ${ }^{112}$.

\footnotetext{
${ }^{109}$ Nos dizeres de PAULO DE BARROS CARVALHO, "só a pessoa, sujeita de direitos fundamentais, como nome, patrimônio e domicílio tem condições de ocupar o tópico de devedor da prestação obrigacional.(...) se o direito tributário é livre e suficiente em si mesmo para traçar os contornos dos fatos que elege, não o será, com certeza, para firmar os termos da chamada obrigação tributária. E o motivo é muito simples: a obrigação tributária é espécie de relação jurídica, da categoria das patrimoniais" (Curso de Direito Tributário, p. 382). ${ }^{110}$ CARVALHO, Paulo de Barros. Direito Tributário, linguagem e método, p. 774.

${ }^{111}$ Ibid., p. 74.

${ }^{112}$ Ibid., 388.
} 
No tocante à solidariedade, o exemplo mais emblemático na seara do ICMS é o caso do transportador que aceita mercadoria para ser transportada sem a respectiva documentação fiscal. Quanto à responsabilidade por sucessão, temos a situação em que a incorporadora assume o ICMS devido pela incorporada. Por fim, quanto à responsabilidade por infração, cite-se o depositário, que é responsável pelo tributo referente às mercadorias depositadas sem nota fiscal.

\subsubsection{Critério quantitativo do ICMS}

$\mathrm{O}$ artigo $155, \S 2^{\circ}, \mathrm{XII}$, alínea "i", ${ }^{113}$ prescreve que compete à lei complementar fixar a base de cálculo do ICMS, estabelecendo, inclusive que o montante do imposto a integre a sua própria base.

No exercício da competência que lhe foi outorgada, o legislador complementar estabeleceu que a base de cálculo é o "valor da operação" de que decorre a saída da mercadoria (artigo 13, inciso I, da Lei Complementar $n^{\circ} 87 / 96^{114}$ ).

Dessa forma, agiu bem o legislador complementar ao dispor no artigo 13, I, da Lei Complementar $n^{\circ} 87 / 96$ que a base de cálculo nas transmissões previstas nos incisos III e IV do artigo 12 é o valor da operação, pois essa grandeza está em sintonia com o critério material do ICMS mercantil. Nesse diapasão, AIRES FERNANDINO BARRETO ${ }^{115}$ afirma que o padrão para medir o fato tributário de operação relativa à circulação de mercadorias é o valor dessa operação.

Questão que ainda suscita debate diz respeito ao artigo $13, \S 1^{\circ}$, da Lei Complementar $\mathrm{n}^{\circ} 87 / 96^{116}$, que prescreve a adição do próprio ICMS na sua base e cálculo.

A Emenda Constitucional no 33/01 convalidou esse entendimento ao acrescentar a alínea "i" ao artigo $155, \S 2^{\circ}$, inciso XII, da Carta Maior, autorizando a lei complementar a

\footnotetext{
113 “Art. 155. Compete aos Estados e ao Distrito Federal instituir impostos sobre: (...) $\S 2 .^{\circ} \mathrm{O}$ imposto previsto no inciso II atenderá ao seguinte: (...)

XII - cabe à lei complementar: (...)

i) fixar a base de cálculo, de modo que o montante do imposto a integre, também na importação do exterior de bem, mercadoria ou serviço."

${ }^{114}$ Art. 13. A base de cálculo do imposto é:

I - na saída da mercadoria prevista nos incisos I, III e IV do art. 12, o valor da operação;

II - na hipótese do inciso II do art. 12, o valor da operação, compreendendo mercadoria e serviço."

${ }^{115}$ BARRETO, Aires Fernandino. Base de cálculo, alíquota e princípios constitucionais. $2^{\mathrm{a}}$ ed. São Paulo:

Max Limonad, 1998. p. 50.

116 " $1^{\circ}$. Íntegra a base de cálculo do imposto:

I - o montante do próprio imposto, constituindo o respectivo destaque mera indicação para fins de controle."
} 
"fixar a base de cálculo do ICMS de modo que o montante do imposto a integre, também na importação do exterior de bem, mercadoria ou serviço".

Para ROQUE ANTÔNIO CARRAZA, mesmo após o advento da referida Emenda, a lei complementar em questão "[...] desvirtuou o arquétipo constitucional desse tributo, levando, por via transversa, à criação de outro, diferente daquele cuja competência a Carta Suprema reservou aos Estados-membros e ao Distrito Federal" ${ }^{117}$. De acordo com o entendimento do Professor, com o qual concordamos, esse adicional tem por hipótese de incidência o fato de alguém pagar ICMS, que não leva em consideração a capacidade contributiva do contribuinte. Contudo, o Supremo Tribunal Federal rejeitou a tese da inconstitucionalidade da regra prescrita no referido enunciado prescritivo $^{118}$.

Com relação às alíquotas, as normas gerais são veiculadas, como vimos, por Resolução do Senado Federal, de forma obrigatória para as alíquotas interestaduais e facultativas no estabelecimento de alíquotas mínimas em operações internas e alíquotas máximas em situações de conflito.

As alíquotas desse imposto deverão ser (e não poderão ser) seletivas em face da essencialidade das mercadorias envolvidas, como prescreve o artigo 155, §2 $2^{\circ}$, III, da Constituição Federal de 1988.

Outro ponto relevante no que tange às alíquotas do ICMS mercantil diz respeito à exigência constitucional, prevista no artigo $155, \S 2^{\circ}$, inciso $\mathrm{VI}^{119}$, da anuência dos Estados e Distrito Federal na estipulação de alíquotas internas em valores inferiores aos determinados pelo Senado Federal para as operações interestaduais. O descumprimento desse mandamento constitucional é uma das causas da conhecida "guerra fiscal do ICMS".

\footnotetext{
${ }^{117}$ CARRAZA, Roque Antônio. ICMS, p. 360.

118 “A Lei Complementar 87/96, ao estabelecer que integra a base de cálculo do ICMS o montante do próprio imposto, vale dizer, a base de cálculo do ICMS corresponderá ao valor da operação ou da prestação somado ao próprio tributo, não ofende o princípio constitucional da não-cumulatividade. Com base nesse entendimento, o Tribunal, por maioria, manteve acordão proferido pelo Tribunal de Justiça do Rio Grande do Sul, que afastava a pretensão da empresa-contribuinte de excluir, da base de cálculo do ICMS o valor do próprio tributo devido, sob a alegação de que tal cobrança ofendia os artigos $5^{\circ}$, XXII, 145, par $1^{\circ}$, 150 e 155 , todos da CF (..) (RE n 212.209-RS).

119 "VI - salvo deliberação em contrário dos Estados e do Distrito Federal, nos termos do disposto no inciso XII, "g”, as alíquotas internas, nas operações relativas à circulação de mercadorias e nas prestações de serviços, não poderão ser inferiores às previstas para as operações interestaduais.
} 


\section{CAPÍTULO III: PETRÓLEO, RECURSOS MINERAIS E SOBERANIA}

\subsection{Evolução dos regimes de mineração no Brasil}

Neste capítulo, analisaremos a evolução dos regimes de mineração no Brasil desde o Período Colonial até os dias atuais, bem como os enunciados constitucionais que dispõem sobre as atividades econômicas do monopólio da União sobre o petróleo, prescritas no artigo 177 da Carta Maior e a sua "flexibilização" com o advento da Emenda Constitucional $n^{\circ}$ 9/95.

Tal análise é fundamental para a devida compreensão do contexto constitucional em que se insere a temática da exploração do petróleo pelos concessionários, fato esse prescrito pela legislação do Estado do Rio de Janeiro como hipótese de incidência do ICMS, que será abordado no capítulo IV.

\subsubsection{Regime regalista do Período Colonial}

Durante o Período Colonial, prevaleceu o regime regalista de propriedade, que tem raízes no Direito Romano e regeu a maioria das monarquias europeias durante o feudalismo. Nesse regime, o subsolo era considerado res nullius, cabendo ao monarca português atribuir a sua exploração a terceiros.

A aplicação desse regime teve início com as Ordenações Manuelinas (1521), que incluíam, dentre os direitos da Coroa Portuguesa, "os veeiros e minas de ouro, ou prata, ou qualquer outro metal" (Título 25, § 15, Livro 2).

As Ordenações Manuelinas foram substituídas pelas Ordenações Filipinas de 1603, as quais atribuíam igualmente ao rei a propriedade das riquezas minerais, que delas podia dispor livremente, concedendo o direito de lavra a quem lhe aprouvesse mediante o pagamento de uma regalia (o quinto da riqueza extraída), como elucida GILBERTO BERCOVICI $^{120}$.

\footnotetext{
120 “As minas eram propriedade da Coroa, caracterizando-se a legislação portuguesa, portanto, por manter o sistema dominial ou regaliano de propriedade do subsolo, distinta da propriedade do solo. A concessão para exploração deveria ser expressa em Foral ou Alvara. O descobridor, como prêmio, deveria ter uma autorização especial do Provedor de Metais para a exploração mineral, recebendo a concessão de uma área previamente demarcada e que deveria ser explorada de forma contínua, sob pena de perda da concessão. A recompensa do descobridor, informa Pandia Calogenas, consistia em ato de domínio praticado pelo Rei, que não se limitava a propriedade real sobre as minas. A data (propriedade territorial destinada a exploração mineral) do descobridor consistia em uma propriedade distinta da do solo, uma propriedade resolúvel, pois estava subordinada à lavra, que era criada e mantida em função da descoberta e da exploração dos recursos
} 
Esse sistema perdurou até a proclamação da Independência, em 1822, quando a propriedade do subsolo, que era atribuída à Coroa portuguesa, passou a pertencer ao Estado brasileiro.

\subsubsection{Regime dominial durante o Brasil Império}

Após a proclamação da independência em 1822, foi publicada a "Lei de 20 de outubro de 1823", a qual estabelecia que as ordenações e os regimentos que regulamentavam o direito das minas no Período Colonial continuaram a vigorar durante o Império, até a edição de um novo código legislativo mineiro.

Dessa forma, durante o Império prevaleceu o sistema de propriedade adotado nos tempos da Colônia, com a diferença de que as minas e quaisquer outras riquezas do subsolo passaram a constituir domínio da Nação. Dessa forma, os bens minerais saíram do domínio da Corte portuguesa (regime realengo) para integrar o domínio do Estado (regime dominial).

Com o advento da Constituição de 1824, foi assegurado ao proprietário da terra o exercício do direito de propriedade em toda a sua plenitude, salvo em caso de interesse público, mediante o pagamento de justa indenização (artigo 179, §22). Referido dispositivo, contudo, não fez nenhuma alusão quanto à propriedade do solo e do subsolo, a propriedade superficial ou às jazidas, o que era desnecessário porquanto os recursos minerais já integravam o domínio da Nação.

Em síntese, da mesma forma que no Período Colonial, a propriedade do solo era distinta da propriedade das minas e jazidas localizadas no subsolo. O dono do solo o era também em relação ao subsolo. No entanto, o seu domínio não abrangia as minas e jazidas, as quais pertenciam ao domínio da Nação independente.

Segundo PAULO VALOIS PIRES ${ }^{121}$, nesse período a maior parte dos empreendimentos estava voltada para a exploração de minerais, como o ouro, a prata, os diamantes etc. Houve apenas algumas iniciativas de particulares visando ao descobrimento do petróleo no subsolo.

minerais. Todos os metais encontrados deveriam, após sua fundição, pagar o quinto real (Ordenações Filipinas, Livro $2^{\circ}$, Título XXXIV, $\S^{\circ}{ }^{\circ}$ )" (BERCOVICI, Gilberto. Direito Econômico do Petróleo e dos Recursos Minerais. São Paulo: Quartier Latin, 2011. p. 56).

${ }^{121}$ PIRES, Paulo Valois. A evolução do monopólio estatal do petróleo. Tese de Mestrado, USP, 1999. p. 12. 


\subsubsection{A Constituição Republicana de 1891 e o regime de acessão}

Com a promulgação da Constituição de 1891, houve uma drástica ruptura com o regime de propriedade do subsolo vigente até então. Foi inaugurado, nesse período, o regime de acessão, por meio do qual foi atribuído ao proprietário do solo também a propriedade do subsolo, ou seja, as minas e jazidas passaram a ser acessórios do solo, nos termos do que dispunha o artigo 72, §17, da primeira Carta Republicana Brasileira ${ }^{122}$.

O Código Civil de 1916 regulou a matéria em conformidade com a Constituição de 1891, estabelecendo, no seu artigo 526, que a propriedade do solo abrangia a do que lhe estava superior e inferior em toda a altura e profundidade, inclusive os recursos minerais, que passaram a ser, assim, um mero acessório do solo.

Ao atribuir ao proprietário da superfície a titularidade do subsolo, a exploração de petróleo e outros recursos minerais ficou a cargo dos particulares, o que denota a ausência de política governamental sobre a exploração petrolífera ${ }^{123}$.

\subsubsection{A Constituição de 1934 e o regime de concessão}

O modelo acessionista sofreu profunda alteração com o Código de Minas de 1934 (Decreto $n^{\circ} 24642 / 34$ ), que separou a propriedade do solo da propriedade do subsolo (artigo $4^{\circ}$ ) e passou para o domínio da União todas as riquezas do subsolo que não fossem objeto de exploração.

Nesse contexto de nacionalização do subsolo brasileiro, o Código de Minas trouxe as figuras das jazidas e minas manifestadas ou conhecidas, que permaneceram sob o domínio privado, bem como as jazidas e minas não manifestadas e não conhecidas, as quais passaram para o domínio da União ${ }^{124}$.

Com o advento da Constituição Federal de 1934, consagrou-se a nacionalização do subsolo em seu artigo 118, segundo o qual “[...] as minas e demais riquezas do sub-solo,

\footnotetext{
122 “Art. 72. A Constituição assegura a brasileiros e estrangeiros residentes no país a inviolabilidade dos direitos concernentes à liberdade, à segurança individual e à propriedade, nos termos seguintes:

$\S 17$. O direito de propriedade mantém-se em toda a plenitude, salvo a desapropriação por necessidade ou utilidade pública, mediante indenização previa. As minas pertencem aos proprietários do solo, salvas as limitações que forem estabelecidas por lei a bem da exploração deste ramo da indústria."

${ }^{123}$ PIRES, Paulo Valois. A evolução do monopólio estatal do petróleo, p. 15.

124 “Art. 5': As jazidas conhecidas pertencem aos proprietários do solo onde se encontrem, ou a quem for por legítimo título.

$\S 1^{\circ}$ - As jazidas desconhecidas, quando descobertas, serão incorporadas ao patrimônio da Nação, como propriedade imprescritível e inalienável."
} 
bem como as quedas d'água, constituem propriedade distincta da do solo para o efeito de exploração ou aproveitamento industrial”.

O artigo 119 da Constituição Federal estabelecia, ainda, que a exploração de minas e jazidas, ainda que de propriedade privada (ou seja, mesmo que cadastradas nos termos do Código de Minas) passa a depender de autorização ou concessão da União, nos termos da lei.

Assim, o legislador constituinte de 1934 retomou o sistema dominial vigente durante o Império, ao lado do sistema de concessão, razão pela qual esse sistema dominial era conhecido como "regime concessional".

Vale salientar também que em 1934 foi instituído o Departamento Nacional de Produção Mineral (DNPM) ${ }^{125}$, que foi uma das iniciativas do governo brasileiro de elaborar uma política para o desenvolvimento das atividades minerais no Brasil.

\subsubsection{O Estado Novo e a Constituição de 1937}

A Constituição de 1937, em seu artigo 143, estabeleceu que:

[...] as minas e demais riquezas do subsolo constituem propriedade distinta da propriedade do solo para o efeito de exploração ou aproveitamento industrial. $\mathrm{O}$ aproveitamento industrial das minas e das jazidas minerais, ainda que de propriedade privada, dependia de autorização federal.

O parágrafo primeiro do referido artigo dispunha ainda que "[...] a autorização só poderá ser concedida a brasileiros, ou empresas constituídas por acionistas brasileiros, reservada ao proprietário preferência na exploração ou na participação dos lucros".

Nota-se, portanto, que foram mantidas as mesmas diretrizes firmadas na Constituição anterior (regime dominial), permitindo ao Estado explorar diretamente os recursos minerais ou autorizar a sua exploração por terceiros.

$\mathrm{Na}$ vigência dessa Constituição, o petróleo era considerado estratégico para o desenvolvimento do Brasil. O general Horta Barbosa defendeu o domínio do Estado sobre os recursos naturais e a importância na execução de uma política petrolífera como elemento da soberania nacional, o que contribuiu para a criação do Conselho Nacional de

\footnotetext{
${ }^{125}$ Dentre as suas atribuições do DNPM, estavam a de (i) executar os trabalhos de pesquisas necessários à lavra das jazidas minerais, (ii) fiscalizar a pesquisa e a lavra das jazidas minerais; (iii) emitir pareceres sobre os pedidos de autorização para pesquisa e concessão de lavra e (iv) realizar estudos sobre os minérios, minerais, rochas, combustíveis e outras substâncias.
} 
Petróleo (CNP), que representou o grande alicerce da política nacionalista de Vargas no setor petrolífero.

\subsubsection{As Constituições de 1946 e 1967 e a manutenção do sistema previsto pela} Constituição de 1937

A Constituição de 1946 manteve o sistema adotado pelas Cartas de 1934 e 1937, estabelecendo que

[...] as minas e demais riquezas do subsolo constituem propriedade distinta da do solo para efeito de exploração ou aproveitamento industrial (artigo 152) e que o aproveitamento dos recursos minerais e de energia hidráulica depende de autorização ou concessão federal (artigo 153).

No tocante à exploração do petróleo, as alterações mais importantes ocorreram no âmbito infraconstitucional, por meio da criação da Petrobras (Lei n ${ }^{\circ}$ 2.004/53).

A Constituição de 1967 também manteve o sistema dominial em relação às jazidas, minas e demais recursos minerais, estabelecendo, da mesma forma que as Constituições passadas, que a exploração das minas e jazidas somente poderia ser outorgada a brasileiros ou sociedades organizadas no país, desde que houvesse concessão ou autorização federal para tanto.

Importante inovação trazida pela Constituição de 1967 foi a participação atribuída ao proprietário do solo nos resultados da lavra, cujo valor era igual ao dízimo do imposto único sobre minerais.

\subsubsection{A Constituição Federal de 1988 e o regime jurídico atual da mineração}

A Constituição Federal de 1988 ampliou as regras consagradas na Constituição de 1967 referentes à atividade de mineração, instituindo, por exemplo, novos preceitos nunca adotados nas legislações pretéritas, como o que determina a obrigação do explorador mineral de reparar o meio ambiente degradado (artigo $225, \S 2^{\circ}$ ).

Tais dispositivos foram distribuídos na Constituição de forma esparsa ${ }^{126}$, e os principais deles (artigo 176 e 177) encontram-se no capítulo referente aos princípios gerais

\footnotetext{
${ }^{126}$ Dentre os dispositivos constitucionais, mencionem-se os que tratam da propriedade dos recursos minerais (artigo 20, IX); da participação dos Estados, do Distrito Federal e Municípios, bem como dos órgãos da Administração Pública Direta da União, no resultado da exploração dos recursos ou compensação financeira por essa exploração (art. $20, \S 1^{\circ}$ ), das competências legislativa e administrativa das pessoas políticas de direito público (art. 21, XXV, 22, XII, 23, XI, 24, VI); da organização dos garimpeiros em cooperativas (art $174, \S \S 3^{\circ}$ e $4^{\circ}$ ), do sistema de exploração e aproveitamento das jazidas minerais $\left(\operatorname{art} .176, \S \S 1^{\circ}\right.$ e $4^{\circ}$ ), da
} 
da atividade econômica (Titulo VI, da Ordem Econômica Financeira: Capitulo I, Dos Princípios Gerais da Atividade Econômica), elencados nos incisos do artigo $170^{127}$, o que demonstra a relevância da matéria.

No tocante à propriedade dos recursos minerais, a atual Carta Maior definiu, expressamente, "os recursos minerais, inclusive os do subsolo" como bens da União (artigo 20, inciso IX). As riquezas do subsolo são, portanto, consideradas propriedade da União. Esse é o chamado regime do domínio público.

Da mesma forma que nas constituições pretéritas, o legislador constituinte estabeleceu, também de forma expressa, a separação das propriedades do solo das do subsolo, ao dispor, no artigo 176, que as "jazidas ${ }^{128}$, em lavra ou não, e demais recursos minerais constituem propriedade distinta da do solo, para efeito de exploração ou aproveitamento, e pertencem à União".

Ressalte-se, entretanto, que o domínio público sobre os recursos minerais não veda a apropriação, pelo particular, dos resultados obtidos com a exploração, pois a própria Constituição assegura ao concessionário a propriedade do produto da lavra (artigo $176^{129}$ ).

O parágrafo único do artigo 176 estabelece que a pesquisa e lavra de recursos minerais somente poderão ser efetuadas mediante autorização ou concessão da União, que são os regimes de exploração minerária.

A autorização de pesquisa, pressuposto para a existência da concessão da lavra ${ }^{130}$, consiste em título autorizativo permissivo para as atividades de análise e estudo da área em

exigência de estudo prévio de impacto ambiental para instalação de atividade de extração mineral, bem como do emprego de técnicas, métodos e substâncias que comportem riscos para o meio ambiente ( $\operatorname{art} 225, \S 1^{\circ}$, IV e V); da obrigação, daquele que explorar recurso minerais, de recuperar o meio ambiente degradado (artigo $225, \S 2^{\circ}$ ) e das pesquisa e lavra das riquezas minerais em terras indígenas (art. $231, \S \S 3^{\circ}$ e $7^{\circ}$ ).

${ }^{127}$ A Constituição Federal de 1988 estabelece, no seu artigo 170, que a ordem econômica fundamenta-se na "valorização do trabalho humano e na livre iniciativa", estabelecendo, ainda, a sua finalidade: "assegurar a todos existência digna, conforme os ditames da justiça social127”, observados os seguintes princípios: soberania nacional, propriedade privada, função social da propriedade, livre concorrência, defesa do consumidor, defesa do meio ambiente, redução das desigualdades regionais e sociais, busca de pleno emprego e tratamento favorecido para as empresas de pequeno porte constituídas sob as leis brasileiras e que tenham sua sede e administração no país.

${ }^{128}$ As jazidas ou depósitos minerais podem ser definidos, de forma simples, como uma concentração local de substâncias minerais ou naturais, inclusive fósseis, tais como carvão e petróleo. Essa definição foi, inclusive, adotada pelo artigo $4^{\circ}$ do Decreto-Lei n ${ }^{\circ}$ 227/67 (Código de Minas): “Considera-se jazida toda massa individualizada de substância mineral ou fóssil, aflorando à superfície ou existente no interior da terra, e que tenha valor econômico; e mina, a jazida em lavra, ainda que suspensa".

129 “Art. 176. As jazidas, em lavra ou não, e demais recursos minerais e os potenciais de energia hidráulica constituem propriedade distinta da do solo, para efeito de exploração ou aproveitamento, e pertencem à União, garantida ao concessionário a propriedade do produto da lavra."

${ }^{130} \mathrm{O}$ art. $2^{\circ}$ do Código de Mineração, ao relacionar esses regimes, separa o "regime" de autorização de pesquisa do "regime" de concessão de lavra. Entretanto, embora submissos à regras próprias, este último sucede ao primeiro, como sua consequência, compondo ambos um regime único, misto, reconhecido na legislação minerária, que o cita repetidamente. Não poderia ser diferente. Afinal, o mesmo direito de 
que se pretende lavrar, sendo definida como a "[...] execução dos trabalhos necessários à definição da jazida, sua avaliação e a determinação da exequibilidade do seu aproveitamento econômico", conforme disposto no art. 14 do Código de Mineração, sob a responsabilidade de profissional habilitado.

Essa autorização significa o aval da União para a execução dos trabalhos destinados ao descobrimento da concentração da substância mineral, que é representado por um título executivo expedido pelo Diretor-Geral do DNPM: o alvará de pesquisa.

A concessão de lavra, por sua vez, pode ser definida como um ato administrativo negocial por meio do qual a União consente ao minerador o direito de aproveitar industrialmente seus recursos minerais ${ }^{131}$, como a extração, o beneficiamento, o transporte e demais atos.

É importante ressaltar, contudo, que essa concessão não outorga ao concessionário a propriedade da jazida identificada, mas apenas o aproveitamento dessa jazida, ou seja, o uso desse bem público. Nesse sentido, CELSO RIBEIRO DE BASTOS assevera que

[...] as jazidas são concentrações de minério em determinada área. Quando se tornam objeto de exploração ganham o nome de mina. Assim sendo, por força do mero contrato de concessão de exploração, o concessionário vai adquirindo o domínio do produto da sua atividade mineralógica, na medida em que o mineral for se desprendendo e deslocando-se do local de origem. Enquanto, portanto, não objeto de lavra, os minerais continuam no domínio da União, nada obstante a concessão de sua exploração. Em consequência continuam impenhoráveis e inalienáveis, enquanto em aderência à jazida ${ }^{132}$.

No tocante aos superficiais, a Constituição Federal não assiste nenhum direito sobre os recursos minerais, garantindo apenas a sua participação nos resultados da lavra, nos termos do parágrafo $2^{\circ}$ do artigo 176 , em decorrência dos transtornos causados com a extração mineral em seu terreno.

Fixado, de forma sintética, o regime jurídico geral aplicável aos recursos minerais previsto no artigo 176 da Constituição Federal, serão analisadas, a seguir, as regras constitucionais específicas do monopólio da União sobre as atividades econômicas da indústria do petróleo, previstas no artigo 177 da Carta Maior.

prioridade que garantir a outorga do título de autorização de pesquisa garantirá, à sequência, a outorga do título de concessão de lavra.

${ }^{131}$ FREIRE, Willian. Natureza jurídica do consentimento para pesquisa mineral, do consentimento para lavra e do Manifesto de Mina no Direito Brasileiro. Belo Horizonte: Mineira Livros Jurídicos, 2005. p. 127 .

${ }^{132}$ BASTOS, Celso Ribeiro; MARTINS, Ives Gandra. Comentários à Constituição do Brasil, $7^{\circ}$ vol. São Paulo: Saraiva, 1990. p. 140 
Para tal desiderato, faz-se necessário discorrer, inicialmente, sobre o conceito de monopólio, para, posteriormente, debruçarmos sobre o monopólio relativo ao petróleo propriamente dito desde a criação da Petrobras até o advento da Emenda Constitucional ${ }^{\circ}$ 9/95.

\subsection{Do conceito de monopólio}

Em termos econômicos, pode-se definir monopólio como a exploração exclusiva de determinada atividade econômica por um único agente, não sendo permitido o ingresso de outros competidores. Na acepção jurídica, monopólio é a supressão da uma atividade do regime de livre iniciativa, imposta pelo Estado em benefício do interesse coletivo ${ }^{133}$.

O monopólio pode ser de fato ou de direito. No monopólio de fato, ou natural, há uma concentração econômica exacerbada, prejudicando a livre concorrência. A ordem jurídica atua para evitar o abuso do poder econômico decorrente dessa situação, nos termos do artigo $173, \S 4^{\circ}$, da Carta Maior ${ }^{134}$.

O monopólio de direito, por sua vez, é criado para a proteção do interesse público, reservando ao Estado a exclusividade da atividade econômica. Como bem esclarece GILBERTO BERCOVICI ${ }^{135}$, “[...] o conceito constitucional de monopólio é de monopólio estatal, ou público, nunca de monopólio privado".

O monopólio estatal é, de acordo com EROS GRAU ${ }^{136}$, uma forma de intervenção do Estado no domínio econômico por absorção, assumindo o Estado o controle integral dos

${ }^{133}$ GASPARINI, Giosenes. Direito Administrativo. $7^{\text {a }}$ ed. São Paulo: Saraiva, 2002. p. 255.

134 “Artigo 173, $\S 4^{\circ}$. A lei poderá reprimir o abuso do poder econômico que vise a dominação dos mercados, a eliminação da concorrência e ao aumento arbitrário dos lucros."

${ }^{135}$ BERCOVICI, Gilberto. Direito Econômico do Petróleo e dos Recursos Minerais, p. 279.

${ }^{136}$ A intervenção econômica em sentido estrito pode dar-se de maneira direta, nas hipóteses de intervenção por absorção (quando o Estado assume integralmente o controle dos meios de produção e/ou troca em determinado setor da atividade econômica, atuando em regime de monopólio) ou participação (quando o Estado assume o controle de parcela dos meios e/ou troca em determinado setor da atividade econômica, atuando em regime de competição).A intervenção estatal no domínio econômico também pode ocorrer de forma indireta, nos casos de intervenção por direção e por indução. Nessas hipóteses, o Estado desenvolve atividade regulatória, estabelecendo mecanismos e normas de comportamento compulsório dos agentes econômicos privados (intervenção por direção) ou manipulando os instrumentos de intervenção em conformidade com as leis que regem o funcionamento dos mercados (intervenção por indução). (GRAU, Eros. A Ordem Econômica na Constituição de 1988. 15ª ed. São Paulo: Malheiros, 2012). Os serviços públicos, como já exposto anteriormente, constituem uma espécie de atividade econômica. De acordo com Eros Grau (2012), “a prestação de serviço público está voltada à satisfação de necessidades, o que envolve a utilização de bens e serviços, recursos escassos. Daí podermos afirmar que o serviço público é um tipo de atividade econômica. Serviço público - dir-se-á mais - é o tipo de atividade econômica cujo desenvolvimento compete, preferencialmente, ao setor público. Não exclusivamente, note-se, visto que o setor privado presta serviço público em regime de concessão ou permissão. Desde aí poderemos também afirmar que o serviço público está para o setor público assim como a atividade econômica está para o setor privado".Com efeito, os serviços públicos são de titularidade do Poder Público, que pode prestá-los 
meios de produção e/ou troca em determinado setor da atividade econômica em sentido estrito.

Saliente-se também que o monopólio diz respeito a uma atividade empresarial, que não se confunde com a propriedade. Por essa razão, EROS GRAU assevera a impropriedade da expressão "monopólio de propriedade" ou "monopólio de um bem". De acordo com o Professor,

[...] não é adversa à Constituição a existência ou desenvolvimento de uma atividade econômica sem que a propriedade do bem empregado no processo produtivo ou comercial seja concomitantemente detida pelo agente daquela atividade - o que também é afirmado por Fabio Konder Comparato. Dizendo-o de outro modo: o conceito de atividade econômica (enquanto atividade empresarial) prescinde da propriedade dos bens de produção ${ }^{137}$.

Feitas essas considerações preliminares sobre o conceito do monopólio, passa-se a analisar a evolução do monopólio sobre as atividades da indústria petrolífera no Brasil.

\subsubsection{A criação da Petrobras e o monopólio do petróleo}

Durante a vigência da Constituição de 1946, foi promulgada a Lei no 2004/53, que instituiu a Petróleo Brasileiro Sociedade Anônima (Petrobras).

Além da criação da Petrobras, a referida lei teve por objeto disciplinar o monopólio da União sobre as atividades vinculadas à indústria do petróleo. Dentre as atividades formadoras do monopólio, estavam as de pesquisa, lavra, refino e transporte marítimo de petróleo, seus derivados e gases raros, estando expressamente excluída do monopólio federal a distribuição de derivados de petróleo.

Referida lei determinou que a Petrobras e suas subsidiárias seriam os órgãos executores do monopólio da União, cabendo ao Conselho Nacional de Petróleo a orientação e fiscalização das atividades decorrentes do petróleo.

O monopólio foi transformado em norma constitucional pela Constituição de 1967 e alterações promovidas pela Emenda Constitucional no 01/69, cujo artigo 169 previu: “[...] a pesquisa e a lavra de petróleo em território nacional constituem monopólio da União, nos termos da lei".

diretamente ou delegar sua execução a particulares, nos termos do que dispõe o artigo 175 da Constituição Federal.

${ }^{137}$ GRAU, Eros. A Ordem Econômica na Constituição de 1988, p. 189. 
As demais atividades vinculadas à indústria petrolífera, ainda que sob o domínio da União, continuaram a ser regidas pela Lei $\mathrm{n}^{\circ} 2.004 / 53$ (pesquisa e lavra de gases raros, refino de petróleo nacional e estrangeiro, transporte marítimo de petróleo bruto e seus derivados de origem nacional, além do transporte por meio de condutos de petróleo, derivados e gases raros).

A indústria do petróleo, então, passou a ter atividades regidas tanto pela Carta de 1967 (pesquisa e lavra) quanto pela Lei $n^{\circ}$ 2.004/53. Segundo PAULO VALOIS PIRES ${ }^{138}$, uma das razões para explicar essa duplicidade é que o legislador somente pretendeu instituir o monopólio constitucional sobre as atividades mais importantes da cadeia petrolífera (pesquisa e lavra), cujo regime, para ser alterado, necessitaria de Emenda Constitucional, e não de uma simples lei federal.

Vale ressaltar que a Constituição de 1967 manteve o sistema dominial em relação a jazidas, minas e demais recursos minerais, de modo que a exploração das jazidas e minas somente poderia ser outorgada a brasileiros ou sociedades organizadas no país, desde que houvesse concessão ou autorização federal para tanto.

Além disso, uma das importantes inovações trazidas pela Constituição de 1967 foi a participação atribuída ao proprietário do solo nos resultados da lavra, cujo valor era igual ao dízimo do imposto único sobre minerais.

\subsubsection{Monopólio previsto na Constituição de 1988 até o advento da Emenda Constitucional $\mathbf{n}^{\circ}$ 9/95}

A Constituição de 1988 ampliou as atividades das indústrias do petróleo e do gás natural que passaram a fazer parte do monopólio da União. Até a promulgação da atual Carta, o monopólio estabelecido pela Constituição de 1967 contemplava apenas as atividades de pesquisa e lavra petrolíferas. O monopólio das demais atividades estava disciplinado pela Lei $\mathrm{n}^{\circ} 2.004 / 53$.

A ampliação das atividades que passaram a integrar o monopólio da União decorreu dos efeitos sobre a economia brasileira das crises de 1973 e 1979 e do insucesso dos "contratos de risco", aliados à concepção de que o petróleo era estratégico para o desenvolvimento do país.

\footnotetext{
${ }^{138}$ PIRES, Paulo Valois. A evolução do monopólio estatal do petróleo, p. 59.
} 
De fato, a Constituição de 1988 incluiu no monopólio da União as seguintes atividades contempladas no artigo 177 :

a) pesquisa e lavra de gás natural e outros hidrocarbonetos fluidos", que já estavam reguladas pela Lei $\mathrm{n}^{\circ} 2004 / 53$,

b) as atividades de refino do petróleo nacional e estrangeiro (artigo 177, inciso II), que também já estavam contempladas no artigo $1^{\circ}$, inciso II da Lei ${ }^{\circ}$ 2.004/53;

c) importação e exportação dos produtos e derivados básicos resultantes das atividades de refino, pesquisa e lavra de petróleo e gás natural (artigo 17, inciso III);

d) transporte marítimo de petróleo bruto de origem nacional e seus derivados básicos e o transporte, por meio de conduto, de petróleo bruto, derivados e gás natural de qualquer origem (tais atividades também estavam contempladas no artigo $1^{\circ}$, inciso III, da Lei $\left.n^{\circ} 2.004 / 53\right)^{139}$.

Outras importantes inovações trazidas pela Constituição de 1988 foram a conferência aos Estados do monopólio da "exploração dos serviços locais e gás canalizado" (artigo $25, \S 2^{\circ}$ ), bem como o disposto no artigo $20, \S 1^{\circ}$, que assegurou aos Estados, ao Distrito Federal, aos Municípios e a outros órgãos da administração direta participação no resultado da exploração do petróleo, mar territorial e zona exclusiva.

Deve-se salientar, ainda, que, com a promulgação da Constituição de 1988, a Petrobras manteve o papel de órgão executor do monopólio do petróleo, e o Conselho Nacional de Petróleo continuou responsável pela fiscalização das atividades relacionadas ao monopólio atribuído à União.

Com o advento da Emenda Constitucional no 9/95, a Petrobras deixou de exercer, com exclusividade, o monopólio da União sobre o petróleo, conforme será demonstrado a seguir.

\footnotetext{
139 “Art. 177. Constituem monopólio da União:

I - a pesquisa e a lavra das jazidas de petróleo e gás natural e outros hidrocarbonetos fluidos;

II - a refinação do petróleo nacional ou estrangeiro;

III - a importação e exportação dos produtos e derivados básicos resultantes das atividades previstas nos incisos anteriores;

IV - o transporte marítimo do petróleo bruto de origem nacional ou de derivados básicos de petróleo produzidos no País, bem assim o transporte, por meio de conduto, de petróleo bruto, seus derivados e gás natural de qualquer origem;

$\mathrm{V}$ - a pesquisa, a lavra, o enriquecimento, o reprocessamento, a industrialização e o comércio de minérios e minerais nucleares e seus derivados.

$\mathrm{V}$ - a pesquisa, a lavra, o enriquecimento, o reprocessamento, a industrialização e o comércio de minérios e minerais nucleares e seus derivados, com exceção dos radioisótopos, cuja produção, comercialização e utilização poderão ser autorizadas sob regime de permissão, conforme as alíneas b e c do inciso XXIII do caput do art. 21 desta Constituição Federal.

$\S 1^{\circ} \mathrm{O}$ monopólio previsto neste artigo inclui os riscos e resultados decorrentes das atividades nele mencionadas, sendo vedado à União ceder ou conceder qualquer tipo de participação, em espécie ou em valor, na exploração de jazidas de petróleo ou gás natural, ressalvado o disposto no art. $20, \S 1^{\circ}$."
} 


\subsubsection{Emenda Constitucional n 9/95 e a "flexibilização" do monopólio do petróleo}

Apesar das descobertas na Bacia de Campos nos anos 70, o Brasil carecia de recursos para financiar a exploração petrolífera ${ }^{140}$, pois era ainda um grande importador de petróleo. A fim de suprir essa deficiência, fazia-se necessário que a Petrobras passasse a desempenhar suas atividades em regime de concorrência com demais empresas de petróleo.

A "flexibilização" do monopólio do petróleo era, de fato, uma preocupação do governo federal, conforme previa a Exposição de Motivos $n^{\circ} 39^{141}$, à qual foi anexada a proposta de alteração do artigo 177 da Constituição Federal elaborada, em conjunto, pelos Ministros da Justiça, da Fazenda, do Planejamento e Orçamento, da Previdência Social e das Minas e Energia.

Após a aprovação pela Comissão de Constituição e Justiça, a proposta foi submetida à apreciação da Comissão Especial do Congresso. Em seu parecer, o deputado Lima Neto esclareceu que a Emenda

[...] não flexibiliza o monopólio da União sobre a indústria do petróleo: na realidade, o mantém na sua integralidade, tal qual configurado no texto constitucional vigente. Apenas - e apenas isto - admite que outras empresas a serem contratadas pela União possam, também, tal qual ocorre com a Petrobras, exercer as atividades monopolizadas. Há aí, na Emenda, unicamente quebra da reserva de mercado atribuída à Petrobras, isto é, fica mantido sem qualquer alteração o monopólio da União.

Depois de inúmeros debates, foi editada, enfim, a Emenda Constitucional $n^{\circ}$ 9/95, que deu nova redação ao artigo $17, \S 1^{\circ}$, da Constituição Federal de 1988, bem como a inclusão do parágrafo $2^{\circ}$. Confira-se:

\footnotetext{
${ }^{140}$ Segundo RAIMUNDO MENDES BRITO, “o Brasil possui 29 bacias sedimentares, cobrindo uma área de 5 milhões e 700 mil $\mathrm{km}^{2}$ no mar, que se encontram em diferentes estágios de exploração, desde o embrionário até o avançado. Desse conjunto, em oito bacias já foram descobertas jazidas de hodrocarbonetos (óleo e gás), nas quais estão concentrados mais de $80 \%$ dos investimentos realizados pela Petrobras em exploração. Isso confirma que a maioria delas encontra-se em estágio exploratório incipiente ou até, praticamente, desconhecido. Uma tarefa de tal porte, com a celeridade de resposta que o Brasil necessita, não pode ser executada com exclusividade pela Petrobras. (...) É preciso somar às atividades da nossa estatal o concurso de investimentos privados". (BRITO, Raimundo Mendes. Flexibilizar significa desenvolver. In: A nova regulamentação da indústria do petróleo no Brasil. Rio de Janeiro: FGV, 1997. p. 8).

141 "A Emenda visa a flexibilizar o monopólio do petróleo de forma que a União possa contratar com empresas privadas a realização das atividades de pesquisa e lavra de petróleo e de gás natural, refino de petróleo, importação e exploração de petróleo, gás e derivados, bem como o transporte marítimo do petróleo, derivados e gás natural, inclusive por meio de dutos" (Exposição de Motivos no 39, publicada no Diário do Congresso Nacional, Seção I, de 16/03/95).
} 


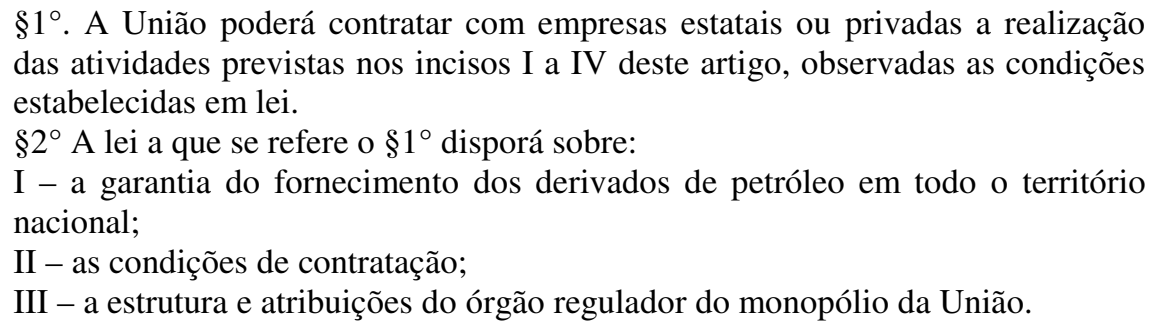

Verifica-se, assim, que a partir da Emenda Constitucional no 9/95, a Constituição Federal de 1988 mantém como monopólio da União a pesquisa e a lavra do petróleo e do gás natural e outros hidrocarbonetos fluidos, mas autoriza a contratação de empresas estatais ou privadas para a consecução dessas atividades, cuja execução cabia exclusivamente à Petrobras, mediante a celebração do contrato com a União. A Lei $\mathrm{n}^{\circ}$ 9.478/97 (Lei do Petróleo) estabeleceu que tal outorga seria feita por meio do contrato de concessão firmado com a ANP.

Não houve, portanto, o fim do monopólio da União, que permaneceu intacto com o advento da referida Emenda Constitucional, tampouco a sua flexibilização, como sustentam alguns autores $^{142}$, mas apenas a delegação de direito de exploração da atividade econômica e produção de petróleo por empresas estatais ou privadas.

Nota-se, assim, que a partir do advento da referida Emenda Constitucional, o Poder Público passou a ter a opção pela manutenção do sistema atual ou pela adoção da concorrência nessa atividade econômica.

Em decorrência dessa situação, surgiu uma nova concepção de monopólio, o qual não está mais relacionado à intervenção estatal no domínio econômico com exclusividade no controle dos meios de produção (intervenção por absorção), como define EROS GRAU, mas ao monopólio de escolha do Poder Público como bem assevera ALEXANDRE DE MORAES $^{143}$, que poderá optar entre a manutenção da pesquisa e a lavra de jazidas de

\footnotetext{
${ }^{142}$ Nesse sentido, cite-se os ensinamentos de JOSÉ AFONSO DA SILVA: “[...] 4. FLEXIBILIZAÇÃO DO MONOPÓLIO. O $\S 1^{\circ}$, do art. 177 da CF na sua redação original incluía no monopólio também o risco e o resultado às atividades nele mencionadas. A Emenda Constitucional 9/1995 deu nova redação a esse parágrafo, para declarar ao contrário, que 'a União poderá contratar com empresas estatais ou privadas a realização das atividades previstas nos incisos I a IV deste artigo observadas as condições estabelecidas em lei'. Quer dizer: flexibilização do monopólio das atividades constantes dos incisos I a IV do art. 177 não opera diretamente da norma constitucional, mas de lei - o que, em verdade, diminui a segurança do monopólio. A Lei referida é a de n. 9.478/1997, que estabelece que as atividades de exploração, desenvolvimento e produção de petróleo e de gás natural serão exercidas mediante contratos de concessão, precedidos de licitação, os quais deverão prever duas fases" (Comentário contextual à Constituição, $5^{\text {a }}$ ed. São Paulo: Malheiros, 2007, p. 730).

${ }^{143}$ MORAES, Alexandre. Regime Jurídico da Concessão para Exploração do Petróleo e Gás Natural, artigo publicado em 11/2011 no sítio eletrônico Jus Navigandi.
} 
petróleo e gás natural e outros hidrocarbonetos fluidos por uma só empresa, ou pela contratação de empresas estatais ou privadas.

\subsubsection{A Lei ${ }^{\circ}$ 9478/97 e o fim do exercício do monopólio exclusivo pela Petrobras}

No Projeto de Lei $n^{\circ}$ 6/97, que culminou na edição da Lei $n^{\circ}$ 9.478/97, o governo deixou transparecer a necessidade de abertura da exploração das atividades petrolíferas à iniciativa privada. A Petrobras deixaria, dessa forma, de ser a única executora do monopólio estatal do petróleo e do gás natural ${ }^{144}$.

Em 07/08/97 foi sancionada pelo Presidente da República a Lei $n^{\circ}$ 9.478/97, que dispôs sobre a política energética nacional, as atividades relativas ao monopólio do petróleo, além da instituição do Conselho Nacional de Política Energética $(\mathrm{CNPE})^{145}$ e a Agência Nacional do Petróleo (ANP) ${ }^{146}$.

$\mathrm{O}$ artigo $3^{\circ}$ da Lei $n^{\circ} 9.478 / 97$ estabeleceu que "[...] pertencem à União os depósitos de petróleo, gás natural e outros hidrocarbonetos fluidos existentes no território nacional, nele compreendidos a parte terrestre, o mar territorial, a plataforma continental e a zona econômica exclusiva".

Ademais, reproduzindo o disposto no artigo 177 da Constituição Federal, o artigo $4^{\circ}$ da Lei $n^{\circ}$ 9.478/97 estabeleceu quais atividades econômicas constituem monopólio da União, estabelecendo, ainda, no seu artigo $5^{\circ}$, que essas atividades serão reguladas e fiscalizadas pela União e poderão ser exercidas no regime jurídico da concessão, autorização ou contratação sob o regime de partilha de produção, por empresas constituídas sob as leis brasileiras, com sede e administração no país (redação dada pela Lei $\mathrm{n}^{\circ}$ 12.351, de 2010).

\footnotetext{
${ }^{144}$ De acordo com a Exposição de Motivos no 23 , do Ministro de Minas e Energia, que acompanhou o Projeto de Lei $\mathrm{n}^{\mathrm{o}}$ 6/97, o projeto de lei "[...] constitui um importante marco. Demonstra que, no Brasil, a indústria de petróleo atingiu a maturidade e está sendo aberta para possibilitar novos investimentos e permitir uma interação equilibrada entre o Estado e a iniciativa privada" (BRITO, Raimundo Mendes. Exposicao de Motivos $\mathbf{n}^{\mathbf{0}}$ 23, do Min. De Minas e Energia, publicada no Diário da Câmara dos Deputados, de 19.jul.1996).

${ }^{145}$ O CNPE é órgão com atribuição de elaborar propostas para assegurar o abastecimento interno e o aproveitamento racional dos recursos energéticos. A Lei $\mathrm{n}^{\circ}$ 9.478/97 conferiu ao CNPE a prerrogativa de estabelecer as diretrizes para importação e exportação de petróleo e derivados, gás natural e condensado, visando ao adequado funcionamento do Plano Anual de Estoques Estratégicos de Combustíveis e do Sistema Nacional de Combustível.

${ }^{146}$ A ANP é uma autarquia especial, com personalidade jurídica de direito público, subordinada ao Ministério de Minas e Energia, que tem por finalidade regular e fiscalizar as atividades integrantes do monopólio do petróleo e gás natural. A Lei $\mathrm{n}^{\circ}$ 9.478/97 conferiu-lhe autonomia patrimonial, administrativa e financeira. Parte dos recursos financeiros da ANP provem de dotações orçamentarias consignadas no Orçamento Geral da União e de receitas decorrentes das participações governamentais (government takes).
} 
A Lei $\mathrm{n}^{\circ}$ 9.478/97 criou, portanto, dois regimes distintos para o exercício dessas atividades econômicas: a autorização para as atividades de transporte, refino, importação e exportação de petróleo, e a concessão para as atividades de exploração e produção de petróleo e gás natural.

\subsection{As compensações financeiras e as participações governamentais previstas na Lei $n^{0}$ 9478/97}

Conforme exposto anteriormente, a Constituição Federal de 1988, no seu artigo 20, inciso IX, reservou à União a propriedade de recursos minerais, inclusive aqueles localizados no subsolo.

Os Estados, Distrito Federal e os Municípios, apesar de não deterem a propriedade dos minerais, possuem interesse na exploração desses recursos em seus territórios, em razão dos impactos sociais, econômicos e ambientais que os projetos de extração e aproveitamento dos minerais proporcionam a esses entes.

Diante desse cenário, o legislador constituinte outorgou, ao lado da União, competência comum aos Estados, ao Distrito Federal e aos Municípios para "registrar, acompanhar e fiscalizar as concessões de direito de pesquisa e exploração de minerais em seus territórios" (artigo 23, inciso IX).

Além disso, a Constituição Federal assegurou aos entes federativos uma remuneração pela exploração de petróleo, gás natural e outros recursos minerais nos respectivos territórios, que poderá, nos termos do artigo $20, \S 1^{\circ}$, ser apurada de duas formas distintas: participação no resultado da exploração ou compensação financeira por essa exploração:

$\S 1^{\text {o }}$ - É assegurada, nos termos da lei, aos Estados, ao Distrito Federal e aos Municípios, bem como a órgãos da administração direta da União, participação no resultado da exploração de petróleo ou gás natural, de recursos hídricos para fins de geração de energia elétrica e de outros recursos minerais no respectivo território, plataforma continental, mar territorial ou zona econômica exclusiva, ou compensação financeira por essa exploração.

Verifica-se, portanto, que o legislador constituinte descentralizou o resultado da exploração desses recursos minerais, como bem observou IVES GANDRA DA SILVA MARTINS ao analisar o referido dispositivo constitucional: 
$\mathrm{O}$ artigo tem nítido objetivo desconcentrador. Pretende fortalecer a federação na medida em que a exploração de um bem que o constituinte outorgou à União, embora situado em Estados e Municípios, inclusive no Distrito Federal, representa perda de patrimônio destes em favor da entidade maior do Estado federativo. Por essa razão, de forma mais explícita, o constituinte houve por bem centralizar a propriedade do bem e descentralizar o resultado de sua exploração $^{147}$.

REGIS FERNANDES DE OLIVEIRA por sua vez, entende que a participação ou compensação diz respeito à partilha entre os entes federativos:

Cremos que o constituinte não foi técnico ou juridicamente preciso, ao utilizar os termos constantes do $\S 1^{\circ}$ do art. 20 da CF. Ambos quiseram referir-se à mesma coisa, ou seja, quando houver a exploração mineral ou de energia elétrica, dos resultados financeiros daí advindos haverá a divisão (partilha ou compensação) entre os entes federativos ${ }^{148}$.

AUTA ALVES CARDOSO analisou, de forma perfunctória, o conteúdo semântico dos vocábulos "compensação financeira" e "participação nos resultado da exploração" em recente trabalho sobre a classificação jurídica das participações governamentais:

[...] os valores que a União receber, em razão da exploração e produção de petróleo e gás, devem ser repassados aos Estados, Municípios e Distrito Federal de duas formas, a saber: (a) compensação financeira, se o ente político suportar, em razão do exercício de atividade lícita em seu território, qualquer gravame, inclusive a perda de receitas tributárias. Assim, a acepção semântica de compensação, utilizada no Texto Supremo, é a de manter o equilíbrio entre o patrimônio de quem suporta em seus domínios a exploração de petróleo e gás, com o patrimônio de quem se beneficia de tal exploração; ou (excludente) (b) a participação no resultado da exploração, que pode traduzir-se em um percentual a ser aplicado sobre o resultado da exploração (e não sobre o valor total da produção), a ser partilhado entre Estados e Municípios produtores, se a exploração ocorrer em seus domínios territoriais, ou entre todos os demais entes políticos, se a exploração se der no mar territorial, na plataforma continental e na zona econômica exclusiva ${ }^{149}$.

A fim de regulamentar o disposto no artigo 20, $\S 1^{\circ}$, da Constituição Federal, foi editada a Lei $\mathrm{n}^{\circ}$ 7.990/89, que estabeleceu o regime de compensação financeira aos Estados, Distrito Federal e Municípios afetados pela exploração desses recursos minerais.

Posteriormente, foi publicada, em 13 de março de 1990, a Lei n 8.001, que definiu os percentuais de distribuição da compensação financeira de que trata a Lei $n^{\circ}$ 7.990/89, especialmente no que tange à geração de energia elétrica e à Usina de Itaipu.

\footnotetext{
${ }^{147}$ MARTINS, Ives Gandra da Silva. Comentários à Constituição do Brasil. $2^{\mathrm{a}}$ ed. São Paulo: Saraiva, 1992. p. 96.

${ }^{148}$ OLIVEIRA, Regis Fernando. Curso de Direito Financeiro. $3^{\mathrm{a}}$ ed. São Paulo: Revista dos Tribunais, 2010. p. 246.

${ }^{149}$ CARDOSO, Auta Alves. A classificação jurídica das denominadas participações governamentais na indústria de petróleo e gás. Tese de Doutorado em Direito, PUC/SP, 2013. p. 312.
} 
Por fim, a Lei n 9.478/97 introduziu novas “compensações financeiras”, que passaram a ser designadas como "participações governamentais", definidas por MARIA D’ASSUNÇÃO COSTA como “[...] encargos que o concessionário explorador ou produtor de petróleo e gás natural deve pagar em virtude da obtenção dos direitos de exploração e/ou sobre as quantidades extraídas da produção de petróleo ou de gás natural" ${ }^{150}$.

Importante advertir, contudo, que o legislador infraconstitucional não obedeceu aos desígnios constitucionais ao tomar o termo compensação, que é o destino constitucional dos valores oriundos da exploração de petróleo e gás, como a forma que a União possui para obter tais valores, como bem ressaltou AUTA ALVES CARDOSO ${ }^{151}$.

\subsubsection{Natureza jurídica das compensações financeiras}

Desde o advento da Constituição Federal de 1988, a natureza jurídica das participações governamentais vem suscitando calorosos debates.

O foco dessa polêmica reside na interpretação do parágrafo $1^{\circ}$ do artigo 20 da Constituição Federal de 1988 em relação à exploração de todos os recursos minerais e de ambas as opções nela previstas, quais sejam: as participações no resultado e as compensações financeiras.

Parte da doutrina entende que as compensações financeiras, opção exercida pelo legislador ordinário, possuem natureza tributária, pelo fato de serem prestações patrimoniais, compulsórias e instituídas em lei federal. Nesse sentido se posicionaram ROQUE ANTÔNIO CARRAZA ${ }^{152}$ e ALBERTO XAVIER ${ }^{153}$. Esse último autor se posicionou no sentido de que a compensação financeira não está conexa à ideia de dano ao patrimônio público, sendo um verdadeiro imposto:

\footnotetext{
${ }^{150}$ COSTA, Maria D’Assunção. Comentários à Lei do Petróleo. $2^{\text {a }}$ ed. São Paulo: Editora Atlas, 2009. p, 234.

151 “[...] não tem amparo em nosso sistema de Direito positivo tomar a compensação, destino da arrecadação, tal como posta no art. $20, \S 1^{\circ}$, da Constituição Federal, como sinônimo de royalty e também como a forma que a União possui para obter coativamente os valores advindos da exploração de petróleo e gás. Assim, se a Constituição Federal determina que seja repassada aos entes políticos compensação, vocábulo que possui acepções semânticas próprias em Direito, não pode o legislador, para solver com simplicidade disputas arrecadatórias, denominá-la de royalty, afastando-se do que determina o Texto Supremo" (CARDOSO, Auta Alves. A classificação jurídica das denominadas participações governamentais na indústria de petróleo e gás).

${ }^{152}$ CARRAZA, Roque Antônio. Natureza Jurídica da Compensação Financeira pela Exploração de Recursos Minerais. Sua manifesta inconstitucionalidade. Revista Justitia. São Paulo. v. 57, n. 171, jul./set. 1995. p. 88-116.

${ }^{153}$ XAVIER, Alberto. Natureza jurídica e âmbito de incidência da compensação financeira por exploração de recursos minerais. Revista Dialética de Direito Tributário. São Paulo v. 29, 1998. p. 10-25.
} 
[...] a expressão "compensação financeira" não está, na Constituição, conexa com qualquer ideia de dano sofrido por entidades públicas, mas sim com a de uma prestação patrimonial que visa a substituir o mecanismo de participação no resultado da exploração, caso a lei ordinária tenha preferido não adotá-lo. A "compensação financeira" é, pois, compensação pela renúncia ao sistema de participação nos resultados de exploração e não compensação por dano.

[...] a afirmação de que ocorre uma "perda de recursos naturais situados em seus territórios" é juridicamente incorreta, uma vez que os domínios dos recursos minerais pertencem à União, pelo que não teria qualquer fundamento a atribuição de um direito de indenização a outros entes políticos não titulares dos bens em causa.

[...] não vislumbramos como se possa falar em prejuízo da União decorrente de "perda" dos recursos minerais que constituem bens próprios, quando a única razão de ser da atribuição da propriedade federal sobre tais recursos é precisamente a de assegurar a exploração ordenada e racional pelos particulares. Ao invés de perda, o que ocorre é uma valorização econômica de recursos pela sua extração e beneficiamento.

Enfim, nenhum elemento literal, racional ou sistemático de interpretação do $\S 1^{\circ}$ do art. 20 da Constituição permite invocar o conceito de prejuízo como fundamento, próximo ou remoto, da prestação patrimonial que contempla, nem estabelecer uma conexão, por mais tênue que seja, entre a prestação patrimonial compulsória em causa e as despesas de infra-estrutura ou similares incorridas para assegurar a exploração dos recursos minerais.

Deve-se, pois, rejeitar-se, sem hesitações, a doutrina do caráter indenizatório da obrigação prevista no $\S 1^{\circ}$ do art. 20 da Constituição Federal.

Em nossa opinião, a figura jurídica em causa vem desenhada no próprio $\S 1^{\circ}$ do art. 20 como um verdadeiro imposto, vez que se trata de "tributo cuja obrigação tributária tem por fato gerador uma situação independente de qualquer atividade estatal específica, relativa ao contribuinte".

As discussões doutrinárias travadas sobre a natureza jurídica das compensações financeiras consideram, principalmente, a origem das receitas auferidas pela União, Estados, Municípios e Distrito Federal.

Segundo HELENO TAVEIRA TORRES, para aferir se determinada receita pública possui ou não natureza tributária, não basta analisar os requisitos prescritos no artigo $3^{\circ}$ do CTN, pois nessa hipótese toda e qualquer receita pública (foros, laudêmios, preços públicos etc.) seria, invariavelmente, tributo. Deve-se verificar se a prestação é uma receita derivada ou não:

De qualquer sorte, seja qual for a construção linguística acolhida para a enunciação da definição do "tributo", algumas características que the são peculiares devem constar da formulação que se lhe adote, quais sejam: natureza pecuniária; regime jurídico de direito público; que não se constitua em penalidade aplicável a ilícito; prestação compulsória, mas, todas essas serão válidas para a devida distinção se tal prestação for previamente qualificada como receita derivada, proveniente do patrimônio privado para o Estado sem qualquer vinculação, direta ou indireta, com o uso do patrimônio público ${ }^{154}$.

154 TORRES, Heleno Taveira, Grandes Questões Atuais do Direito Tributário. In: A compensação financeira devida pela utilização de recursos hídricos, exploração de recursos minerais ou produção de petróleo, xisto betuminoso e gás natural (art. 20, \$1 $\mathbf{0}, \mathbf{C F}$ ) - Sua natureza jurídica. São Paulo: Dialética, 1999. 2 v. p. 137. 
Nota-se, portanto, a relevância da distinção entre receita pública originária e derivada, como bem assevera ALIOMAR BALEEIRO ao discorrer sobre a Teoria dos Ingressos, cujas lições foram expostas pelo Professor FERNANDO FACURY SCAFF ao discorrer sobre a natureza jurídica da Compensação Financeira pela Exploração de Recursos Minerais (CFEM):

Os ingressos públicos dividem-se em movimentos de fundos e em receitas. São
singelos Movimentos de Fundos aqueles ingressos que geram uma contrapartida
de devolução dos valores arrecadados. Daí que os empréstimos ao Tesouro e sua
restituição, bem como as cauções, fianças e depósitos se caracterizam por ser
uma Movimentação de Fundo, não havendo um acréscimo de valor aos cofres
públicos, em face de serem restituíveis.
Por outro lado, a Receita Pública caracteriza-se por ser um acréscimo de valor
carreado aos cofres públicos, não sendo de sua essência a restituição. Dividi-se
em dois grandes grupos: as Receitas Originárias e as Receitas Derivadas.
As Receitas Originárias, como o próprio nome já indica, possuem sua gênese na
exploração do próprio patrimônio do Estado. São as que decorrem da exploração
de terras, dos recursos hídricos, dos recursos minerais, das instalações industriais
e comerciais do Estado, e por aí assim. Ou seja, a formação dos preços decorre
de uma relação quase que "de mercado", ou, dizendo melhor, "de mercado
regulado". São transações contratuais do Estado, fruto da exploração do seu
próprio patrimônio.
Já as receitas derivadas, como o nome indica, derivam do poder de império do
Estado. Daí surgem os tributos e as multas. Não decorrem de uma exploração de
bens públicos, mas do exercício do poder; daí decorrerem de poder de império, e
não de uma relação contratual 155 . O Supremo Tribunal Federal, ao julgar o Mandado de Segurança ${ }^{\circ} 24.312$, firmou entendimento de que as participações governamentais, espécies de compensações financeiras, são receitas originárias dos Estados, Distrito Federal e dos Municípios, razão pela qual cada ente beneficiado detém a competência para fiscalizar diretamente a sua arrecadação. Confira-se:

MANDADO DE SEGURANÇA. ATO CONCRETO. CABIMENTO.
EXPLORAÇÃO DE PETRÓLEO, XISTO BETUMINOSO E GÁS NATURAL.
PARTICIPAÇÃO, EM SEU RESULTADO, DOS ESTADOS, DISTRITO
FEDERAL E MUNICÍPIOS. CONSTITUIÇÃO FEDERAL, ART. 20, § $1^{\circ}$.
COMPETÊNCIA DO TRIBUNAL DE CONTAS DO ESTADO DO RIO DE
JANEIRO PARA A FISCALIZAÇÃO DA APLICAÇÃO DOS RECURSOS
ORIUNDOS DESTA EXPLORAÇÂOO NO TERRITÓRIO FLUMINENSE.
1 - Não tendo sido atacada lei em tese, mas ato concreto do Tribunal de Contas
da União que autoriza a realização de auditorias nos Municípios e Estado do Rio
de Janeiro, não tem aplicação a Súmula 266 do STF.
$\mathbf{2}$ - Embora os recursos naturais da plataforma continental e os recursos
minerais sejam bens da União (CF, art. 20, V e IX), a participação ou
compensação aos Estados, Distrito Federal e Municípios no resultado da

${ }^{155}$ SCAFF, Fernando Facury. Aspectos controvertidos da CFEM - Compensação financeira pela exploração de recursos minerais (royalties da mineração). In: Direito Tributário e Econômico aplicado ao meio ambiente e à mineração. São Paulo: Quartier Latin, 2009. p. 288-289. 
exploração de petróleo, xisto betuminoso e gás natural são receitas originárias destes últimos entes federativos $\left(\mathrm{CF}\right.$, art. $\left.20, \S \mathbf{1}^{\circ}\right)$.

3 - É inaplicável, ao caso, o disposto no art. 71, VI da Carta Magna que se refere, especificamente, ao repasse efetuado pela União - mediante convênio, acordo ou ajuste - de recursos originariamente federais.

4 - Entendimento original da Relatora, em sentido contrário, abandonado para participar das razões prevalecentes.

5 - Segurança concedida e, ainda, declarada a inconstitucionalidade do arts. $1^{\circ}$, inc. XI e 198, inc. III, ambos do Regimento Interno do Tribunal de Contas da União, além do art. 25, parte final, do Decreto $\mathrm{n}^{\circ} 1$, de 11 de janeiro de 1991. (MS 24312, Mi. Ellen Gracie, DJ de 19/12/2003).

Apesar desse posicionamento, compartilhamos do entendimento de AUTA ALVES CARDOSO, para quem somente a União aufere receita originária na exploração dos recursos minerais, mas não os Estados, os Municípios e o Distrito Federal, que apenas têm direito ao repasse desses valores sob a forma de compensação ou participação no resultado da exploração:

[...] a única pessoa política que aufere receita originária é a União Federal, por ser a proprietária do patrimônio público explorado. Estados, Municípios e o Distrito Federal têm direito ao repasse das verbas advindas do resultado da exploração quer a título de compensação financeira, quer como participação no resultado.

É preciso observar que uma coisa é a União receber royalties, na qualidade de proprietária do patrimônio público explorado pelo particular, outras são as imposições que, por força de lei, incidem sobre o patrimônio do particular (produto da lavra) tomando por base de cálculo a produção ou o lucro do campo. As chamadas "participações governamentais" que incidirem, por força de lei, sobre o patrimônio do particular, possuindo natureza tributária, constituem-se em receita derivada da União, auferida mediante o exercício de sua atividade impositiva. Os royalties que a União recebe, em razão da exploração pelo particular do seu patrimônio, classificam-se como receita originária de tal ente político. As receitas que os Estados, Municípios e Distrito Federal recebem a título de compensação ou participação no resultado da exploração de petróleo e gás são receitas repassadas ${ }^{156}$.

Nesse mesmo sentido, GILBERTO BERCOVICI aduz que:

[...] Os Estados e Municípios têm direito a receber parte dos recursos arrecadados com a CFEM em virtude do artigo $20, \S 1^{\circ}$ da Constituição, mas não têm competência para arrecadar e fiscalizar diretamente as receitas, que são recolhidas pelo DNPM e, posteriormente, repassadas aos entes da Federação. Afinal, a CFEM é uma receita pública originária da União, não dos entes federativos, pois os recursos minerais são bens de domínio da União. Nesse sentido, o Supremo Tribunal Federal errou ao julgar o Mandado de Segurança $n^{\circ}$ 24.312-1/DF (Relatora: Ministra Ellen Gracie), em 19 de fevereiro de $2002^{157}$.

\footnotetext{
${ }^{156}$ CARDOSO, Auta Alves. A classificação jurídica das denominadas participações governamentais na indústria de petróleo e gás, p. 278.

${ }^{157}$ BERCOVICI, Gilberto. Direito Econômico do Petróleo e dos Recursos Minerais, p. 331
} 


\subsubsection{Espécies de participações governamentais}

As participações governamentais, cujos critérios de cálculo e cobrança foram regulamentados pelo Decreto ${ }^{\circ} 2.705 / 98$, são de quatro espécies: (i) bônus de assinatura; (ii) royalties; (iii) participação especial e (iv) pagamento pela ocupação ou retenção da área.

Não pretendemos, discorrer sobre cada uma delas de forma detalhada por fugir ao escopo deste trabalho, mas apenas classificá-las de forma sintética.

\subsubsection{Bônus de assinatura}

Previsto no artigo 45, I, da Lei do Petróleo e artigos 9 e 10 do Decreto n ${ }^{\circ}$ 2.705/98, trata-se de valor pago pela concessionária, em uma única parcela, no ato da assinatura do contrato de concessão, para obtenção da concessão de petróleo ou gás natural.

O valor mínimo está previsto no edital de concessão, independentemente do êxito nas fases de exploração e produção. Referido valor deve atender aos princípios da razoabilidade, proporcionalidade, finalidade e eficiência, como esclarece MARIA D’ASSUNÇÃO DA COSTA:

[...] sua forma de avaliação e mensuração se dá no momento prévio da elaboração do edital, e deve fundamentar-se nos princípios da razoabilidade, proporcionalidade, finalidade e eficiência com os dados geológicos e opções tecnológicas para que os valores previstos na norma editalícia não se transformem num impedimento à participação dos agentes econômicos. Ao contrário, a justa medida do seu valor pode servir de incremento à maior participação de ofertantes, ampliando a concorrência entre eles, porque a licitação visa realizar a competição entre o maior número possível de proponentes para buscar melhor proposta ${ }^{158}$.

Importante destacar que parte dos recursos decorrentes do bônus de assinatura deve ser destinada à ANP, nos termos do artigo 15, inciso II, da Lei $n^{\circ} 9.478 / 97^{159}$. Não há, contudo, qualquer previsão na referida lei acerca dos critérios para a participação dos outros entes federativos no resultado da arrecadação dessa participação governamental, como demanda o artigo 20, $\S 1^{\circ}$, da Constituição Federal de 1988.

\footnotetext{
${ }^{158}$ COSTA, Maria D’Assunção. Comentários à Lei do Petróleo, p. 241.

159 “Art. 15. Constituem receitas da ANP:

(...)

II - parcela das participações governamentais referidas nos incisos I e III do art. 45 desta Lei, de acordo com as necessidades operacionais da ANP, consignadas no orçamento aprovado."
} 
Ao discorrer sobre essa participação governamental, AUTA ALVES CARDOSO afirma que o bônus de assinatura pode ser classificado como verdadeiro royalty (designado por ela como o "pagamento devido por todo aquele que explora direito de outrem"). Por esse motivo, a autora defende que a compensação financeira, prevista no $\operatorname{artigo} 20, \S 1^{\circ}$ não pode ser confundida com royalties:

\begin{abstract}
Para nós, o bônus de assinatura traduz-se num pagamento pelo direito de exploração do bloco, que o concessionário faz à União Federal pelo direito de explorar o patrimônio a Ela pertencente. Em sendo assim, tal verba pode ser classificada como royalty, considerando-se que os royalties são tomados neste trabalho como o pagamento devido por todo aquele que explora direitos de outrem.

Logo, a compensação financeira, tal como posta no art. $20, \S 1^{\circ}$, da Constituição Federal, devida aos Estados, Municípios e Distrito Federal, em razão do ônus que suportam, decorrentes da exploração de petróleo e gás, não pode ser tida como royalties, já que estes são exclusivamente devidos ao detentor dos direitos exploratórios, no caso, a União Federal ${ }^{160}$.
\end{abstract}

\title{
3.3.2.2. Royalties
}

Os denominados royalties consistem em uma das formas mais antigas de pagamento de direitos e propriedade. Nesse sentido, JOSÉ ROBERTO RODRIGUES AFONSO e SÉRGIO WUFF GOBETTI ${ }^{161}$ esclarecem:

\begin{abstract}
A palavra royalty vem do inglês royal, que significa "da realeza" ou "relativo ao rei". Originalmente, era o direito que o rei tinha de receber pagamentos pelo uso de minerais em suas terras. Na literatura econômica, os royalties são comumente tratados como uma forma de renda, seja no conceito ricardiano (relacionado especificamente à terra), seja no conceito marshalliano (vinculado aos rendimentos de todos os bens escassos da natureza).
\end{abstract}

O termo royalty foi empregado, pela primeira vez, na Lei $\mathrm{n}^{\circ}$ 9.478/97. Ante disso, esse tipo de participação governamental na atividade petrolífera já existia, mas era denominado indenização, num primeiro momento, e, posteriormente, compensação ${ }^{162}$. A

\footnotetext{
${ }^{160}$ CARDOSO, Auta Alves. A classificação jurídica das denominadas participações governamentais na indústria de petróleo e gás, p. 110.

${ }^{161}$ AFONSO, José Roberto Rodrigues. Rendas do Petróleo no Brasil: Alguns Aspectos Fiscais e Federativos. Revista do BNDES. Rio de Janeiro, v. 15, 2008. p. 236.

${ }^{162}$ A indenização pela exploração do petróleo foi instituída pela Lei $\mathrm{n}^{\circ} 2.004 / 53$, a qual previa o pagamento aos Estados e Territórios de um valor correspondente a uma alíquota de 5\% sobre o valor do petróleo extraído em terra (onshore). A Lei $\mathrm{n}^{\circ} 7990 / 89$, por sua vez, tratava os royalties como compensação financeira, que deveria ser paga aos Estados, Distrito Federal e Municípios sobre o valor do óleo bruto, do xisto betuminoso e do gás extraído de seus respectivos territórios, onde se fixar a lavra do petróleo ou se localizarem instalações marítimas ou terrestres de embarque ou desembarque de óleo bruto ou gás natural, operados pela Petrobras.
} 
doutrina e a jurisprudência também adotam acepções diversas para esse termo, como bem assinala AUTA ALVES CARDOSO, para quem os royalties são classificados por sua destinação $^{163}$.

De acordo com a autora, o vocábulo royalty deve ser entendido como "a contraprestação financeira devida pelo usuário de um direito pertencente a outrem”, ou seja, o direito de explorar e produzir petróleo. Por esse motivo, somente a União pode receber os royalties, por ser a detentora do patrimônio público explorado, que não se confunde com a compensação financeira prevista no artigo $20, \S 1^{\circ}$, da Constituição Federal $^{164}$.

Os denominados royalties estão previstos no artigo 45, inciso II, da Lei $\mathrm{n}^{\circ}$ 9.478/97. São devidos pelos concessionários de exploração e produção de petróleo ou gás natural e devem ser pagos mensalmente, com relação a cada campo, vedadas quaisquer deduções, mediante a multiplicação do equivalente a $10 \%$ do volume total de produção e gás natural pelos seus respectivos preços de referência, definidos no capítulo IV do Decreto $\mathrm{n}^{\circ} 2.705 / 1998$.

Nos termos do artigo $47, \S 1^{\circ}$, da referida lei, a alíquota de $10 \%$ poderá ser reduzida pela ANP para $5 \%$ em razão de riscos geológicos, expectativas de produção e outros fatores.

\footnotetext{
163 “[...] os royalties possuem diferentes acepções semânticas, com diferentes consequências jurídicas. A doutrina e a jurisprudência ora os tomam como indenização, compensação, imposto e como fruto de arrecadação (compensação financeira). Tal tratamento confuso, no que atine à exploração de petróleo e gás, deve-se à incorporação acrítica ao direito positivo brasileiro do que é praticado na indústria de petróleo e gás no exterior, sem que tenha havido um critério classificatório de tal instituto. Verifica-se que os royalties são classificados por sua destinação, havendo poucas reflexões quanto à sua forma de instituição (CARDOSO, Auta Alves. A classificação jurídica das denominadas participações governamentais na indústria de petróleo e gás, p. 156).

164 "Concluindo estas reflexões sobre os royalties temos que:

a) a compensação financeira prevista no art. $20 \S 1^{\circ}$ da Constituição Federal não se traduz em royalty visto que, pelo Texto Supremo, a mesma é devida aos Estados, Municípios e Distrito Federal que não são os detentores do patrimônio público explorado;

b) só faz jus ao pagamento de royalties a União Federal na qualidade de proprietária do patrimônio público explorado;c) a compensação financeira, prevista no Texto Constitucional, deve ser partilhada entre os entes políticos que suportam os efeitos negativos da exploração de petróleo e gás e perdas tributárias. Já a participação no resultado da exploração pode dar-se entre todos os entes políticos, sejam produtores ou não, quando a exploração ocorrer no mar territorial, na plataforma continental e na zona econômica exclusiva;d) a titularidade do produto da lavra de petróleo e gás pertence ao concessionário ou ao contratado, a teor do que dispõem os arts. 176 e 177 da Constituição Federal, art. 26 da Lei 9478/97, o art. $2^{\circ}$, inciso III, da Lei 12.351/2010 e a jurisprudência do Supremo Tribunal Federal.Isso posto, temos que as imposições, veiculadas por meio de leis ordinárias federais (Lei $\mathrm{n}^{\circ}$ 9478/97, Lei $\mathrm{n}^{\circ}$ 12.351/2010 e Lei $\mathrm{n}^{\circ} 12.734 / 12$ ) incidentes sobre a receita bruta dos campos de petróleo e gás, oneram o patrimônio do particular, consistindo, portanto, receita derivada da União, de natureza tributária." (Ibid.).
} 
No regime de partilha de produção, que será comentado adiante, os royalties são apurados mediante a aplicação da alíquota de $15 \%$ do valor de produção, devendo ser recolhidos a partir do início da produção comercial.

Os royalties também revelam natureza tributária da espécie imposto, como reconheceu AUTA ALVES CARDOSO, que prefere denominá-lo "imposto sobre a produção de petróleo e gás":

\begin{abstract}
A espécie tributária eleita pelo legislador infraconstitucional para onerar a exploração e produção de petróleo e gás, tal como postas na lei 9.478/1997 e lei 12.351/2010, sob a denominação de royalties ou compensação financeira, foi a do imposto.

Há a tributação por meio de um imposto toda vez que em razão do exercício de atividade lícita, alguém é obrigado, por força de lei, a levar dinheiro aos cofres públicos. Cotejando a legislação instituidora da imposição estatal sobre a produção de petróleo e gás, tanto nos contratos de concessão, como nos contratos de partilha de produção e cessão onerosa, como o art. $3^{\circ}$ do Código Tributário Nacional, verifica-se, de imediato, que as leis 9.478/1997, 12.351/2010, 12.276/2010 instituíram um tributo. E tributo é porque se trata de: (a) uma prestação pecuniária, visto que todo aquele que explorar petróleo e gás deve recolher aos cofres públicos um valor em dinheiro (um percentual sobre a produção comercial do campo); (b) compulsória, visto que o vínculo obrigacional decorre de lei; (c) que não se constitui em sanção de ato ilícito, a atividade exploratória é lícita, dela participando o próprio Estado; (d) instituída em lei, a exação em foco foi instituída pelas leis 9.478/97, 12.531/2010 e $12.276 / 2010$ e (e) cobrada mediante atividade administrativa plenamente vinculada, a cobrança do débito do explorador é passível de lançamento e cobranças fiscais.

Logo, na acepção semântica que lhe deu o legislador infraconstitucional a imposição sobre a exploração de petróleo e gás, impropriamente denominada de royalty ou compensação financeira, traduz-se num tributo, especificamente num imposto ${ }^{165}$.
\end{abstract}

\title{
3.3.2.2.1. Distribuição dos royalties
}

Não discorreremos, neste estudo, sobre as questões relativas à constitucionalidade da divisão dos royalties entre os entes da federação, implementada pela Lei $\mathrm{n}^{\circ}$ 12.734/2012, que modificou a Lei $n^{\circ} 9.478 / 97$ e a Lei $n^{\circ} 12.351 / 2010$, mas apenas a forma como se procede tal partilha, abaixo ilustrada ${ }^{166}$ :

\footnotetext{
${ }^{165}$ CARDOSO, Auta Alves. A classificação jurídica das denominadas participações governamentais na indústria de petróleo e gás, p. 235.

${ }^{166}$ COÊLHO, Sacha Calmon Navarro. Royalties do petróleo. A lei é constitucional. Belo Horizonte: Editora Luminus, 2013. p. 20-21.
} 


\begin{tabular}{|c|c|c|}
\hline \multicolumn{3}{|c|}{ REGIME DE PARTICIPAÇÃO DOS ROYALTIES } \\
\hline ZONA EXPLORADA & LEI 9.478/1 & LEI 12.734/2012 \\
\hline \multirow{8}{*}{$\begin{array}{l}\text { Lavra em terra ou } \\
\text { lagos, rios, ilhas } \\
\text { fluviais e lacustres }\end{array}$} & \multicolumn{2}{|c|}{ Royalties de até $5 \%$} \\
\hline & $\begin{array}{l}\text { Estados produtores: } 70 \% \\
\text { Municípios produtores: } 20 \%\end{array}$ & $\begin{array}{l}\text { Estados produtores: } 70 \% \\
\text { Municípios produtores: } 20 \%\end{array}$ \\
\hline & Municípios com instalações: $10 \%$ & Municípios afetados: 10\% \\
\hline & \multicolumn{2}{|c|}{ Parcela que superar os $5 \%$} \\
\hline & Estados produtores: $52,5 \%$ & Estados produtores: $52,5 \%$ \\
\hline & Municípios produtores: $15 \%$ & Municípios produtores: $15 \%$ \\
\hline & Municípios afetados: 7,5\% & Municípios afetados: 7,5\% \\
\hline & União: 25\% & União: $25 \%$ \\
\hline \multirow{13}{*}{$\begin{array}{c}\text { Plataforma } \\
\text { continental, mar } \\
\text { territorial ou zona } \\
\text { econômica } \\
\text { exclusiva (ZEE) }\end{array}$} & \multicolumn{2}{|c|}{ Royalties de até $5 \%$} \\
\hline & Estados confrontantes: $30 \%$ & Estados confrontantes: $20 \%$ \\
\hline & Municípios confrontantes: 30\% & Municípios confrontantes: $17 \%$ \\
\hline & Municípios com instalações: $10 \%$ & Municípios afetados: $3 \%$ \\
\hline & União: $20 \%$ & União: $20 \%$ \\
\hline & Fundo (todos, menos União): $10 \%$ & Fundo - Estados e DF: $20 \%$ \\
\hline & \multicolumn{2}{|c|}{ Parcela que superar os $5 \%$} \\
\hline & Estados confrontantes: 22,5\% & Estados confrontantes: $20 \%$ \\
\hline & Municípios confrontantes: $22,5 \%$ & Municípios confrontantes: $17 \%$ \\
\hline & Municípios afetados: 7,5\% & Municípios afetados: $3 \%$ \\
\hline & União: 40\% & União: $20 \%$ \\
\hline & Fundo (todos, menos União): 7,5\% & Fundo - Estados e DF: $20 \%$ \\
\hline & & Fundo - Municípios: 20\% \\
\hline
\end{tabular}

\section{3.2.3. Participação especial}

A Participação Especial, prevista no artigo 45, III, da Lei do Petróleo e artigos 21 a 27 do Decreto $n^{\circ}$ 2.705/98, é devida pelos concessionários de exploração e produção de petróleo ou gás natural, nos casos de grande volume de produção ou de grande rentabilidade.

Sua apuração é trimestral e incide sobre a receita bruta da produção, deduzidos os royalties, os investimentos da exploração, os custos operacionais, a depreciação e os tributos previstos na legislação.

As alíquotas adotadas são progressivas, de acordo com a localização da lavra, o número de anos de produção e o volume de produção fiscalizada no trimestre.

De acordo com a classificação adotada por AUTA ALVES CARDOSO, a participação especial é um imposto. Confira-se:

Assim, temos que a participação especial classifica-se como tributo, mais precisamente um imposto, que incide sobre a receita líquida da exploração do campo (lucro). 
Note-se que tal imposição submete-se aos ditames do art. $3^{\circ}$ do Código Tributário Nacional (Lei 5.172, de 25 de outubro de 1966). Como imposto inserido na competência residual da União, deveria ser veiculado por meio de lei complementar, o que não ocorreu, razão que aponta para a sua inconstitucionalidade. Além disso, o imposto inserido na competência residual da União não pode ser cumulativo e ter base de cálculo ou fato jurídico tributário próprio dos demais tributos discriminados na Constituição Federal. Aqui vale lembrar que imposto sobre a renda e a contribuição social sobre o lucro líquido (CSLL) já oneram o lucro, de sorte que a não-cumulatividade prevista no art. 154, I do Texto Supremo resta desatendida ${ }^{167}$.

\subsubsection{Pagamento pela retenção da área ou taxa de ocupação}

Essa participação governamental, prevista no artigo 51 da Lei do Petróleo e artigo 28 do Decreto $\mathrm{n}^{\circ} 2.705 / 98$, corresponde ao pagamento devido pelos concessionários aos proprietários do solo em virtude da ocupação ou retenção da área, cujo valor será apurado a cada ano civil durante o período prorrogado, nos termos do parágrafo único do artigo 51 da Lei ${ }^{\circ} 9478 / 97 .^{168}$

A ocupação da área está associada à realização, pelo concessionário, das atividades necessárias à implementação do objeto contratual. A retenção da área, por sua vez, está associada ao simples fato de o concessionário manter, por meio de um contrato de concessão com a ANP, os direitos exclusivos de realizar atividades em determinada área de concessão, impossibilitando que esta, em todo ou em parte, seja destinada a outro concessionário.

Ressalte-se ainda que essa compensação financeira não requer nenhuma contraprestação por parte do Estado, razão pela qual não se pode afirmar que se trata de um aluguel de área, como bem observou JOSÉ GUTMAN ${ }^{169}$.

De acordo com o artigo $16^{170}$ da referida lei, os recursos provenientes dessa participação governamental serão exclusivamente utilizados para o financiamento das despesas da ANP no exercício de suas atividades.

AUTA ALVES CARDOSO classificou esse pagamento também como imposto ${ }^{171}$.

\footnotetext{
${ }^{167}$ CARDOSO, Auta Alves. A classificação jurídica das denominadas participações governamentais na indústria de petróleo e gás, p. 116/117.

168 "Parágrafo único. O valor do pagamento pela ocupação ou retenção de área será aumentado em percentual a ser estabelecido pela ANP, sempre que houver prorrogação do prazo de exploração."

${ }^{169}$ GUTMAN, José. Tributação e outras obrigações na indústria do petróleo. Rio de Janeiro: Freitas Bastos Editora, 2002. p. 118.

170 “Art. 16. Os recursos provenientes da participação governamental prevista no inciso IV do art. 45, nos termos do art. 51, destinar-se-ão ao financiamento das despesas da ANP para o exercício das atividades que lhe são conferidas nesta Lei."

171 “O pagamento pela ocupação da área ou retenção da área traduz-se num imposto, cobrado pela União e destinado à ANP. Nos termos do art. 154, I, do Texto Supremo, tal tributo só poderia ser instituído por lei complementar, desde que não fosse cumulativo, não tivesse fato imponível tributário e base de cálculo
} 


\title{
3.4. Dos demais regimes regulatórios das atividades de exploração e produção de petróleo e gás natural
}

\author{
Além do regime de concessão previsto na Lei $n^{\circ}$ 9478/97, que será \\ comentado de forma detalhada adiante, é importante destacar a existência de outros três \\ regimes adotados por países produtores de petróleo e gás natural: a partilha de produção, o \\ contrato de serviços e a joint venture, cujas principais características também serão \\ expostas de forma sintética, por fugir ao objetivo do presente trabalho. \\ Nesse desiderato, servimo-nos novamente das lições de AUTA ALVES \\ CARDOSO:
}

próprios de outros impostos previstos na Constituição Federal, o que não se verifica na hipótese, maculandoo de inconstitucionalidade" (CARDOSO, Auta Alves. A classificação jurídica das denominadas participações governamentais na indústria de petróleo e gás, p. 314).

\begin{abstract}
Concessão, também referida como Licença e Lease em determinados países produtores, é o regime jurídico jurídico-regulatório por meio do qual o titular originário dos direitos sobre os hidrocarbonetos - via de regra o Estado concede a uma ou mais companhias exploradoras, nacionais ou estrangeiras, exclusividade na exploração e produção de hidrocarbonetos, por sua conta e risco, em determinada área. As companhias exploradoras, então, se tornam proprietárias da produção e podem dela dispor livremente, observando as regras do contrato e da legislação aplicável. Na concessão, normalmente, o Estado hospedeiro não participa diretamente de sua atividade e, portanto, não recebe os recursos oriundos da venda de produção. Sua contrapartida é o pagamento de tributos e participações governamentais (geralmente royalties) pelas companhias exploradoras.
\end{abstract}

A partilha de produção é um contrato firmado entre o Estado hospedeiro, via de regra por meio de sua empresa estatal, e a companhia exploradora, por meio do qual o primeiro contribui primordialmente com a área territorial a ser explorada, e a empresa exploradora, geralmente, conduz as atividades de exploração e produção a seu próprio risco e custo. Uma vez encontradas reservas comercializáveis, a empresa exploradora recebe a sua parte dos hidrocarbonetos produzidos como custo em óleo, nos termos definidos no contrato. A principal diferença que o contrato de partilha apresenta em relação ao contrato de concessão está no fato de que no contrato de partilha de produção o hidrocarboneto extraído permanece sob propriedade da União. Nessa modalidade de contratação, o Estado participa diretamente das atividades de E\&P, geralmente por meio de sua empresa petrolífera, podendo atuar como operador ou não; o Estado recebe sua parcela da produção definida no contrato de partilha, não sendo, via de regra, remunerado por meio de royalties e tributos pelas companhias exploradoras. No Brasil, os contratos de partilha preveem que o Estado será remunerado por meio de royalties e tributos pelas companhias exploradoras.

$(\ldots)$

O contrato de serviços é geralmente adotado naqueles Estados em que o direito de explorar e produzir hidrocarbonetos é atribuição exclusiva da empresa estatal, não havendo outorga às companhias exploradoras. Ou seja, nesses países produtores as empresas exploradoras têm pouco ou nenhum acesso às atividades de E\&P e, logo, às reservas de hidrocarbonetos. 
(...)

Joint venture consiste na formação de uma sociedade com propósito específico. Portanto, a relação societária entre as partes se dá no âmbito do regime jurídicocontratual da joint venture, não havendo a celebração de contratos de concessão ou de partilha de produção. Esse regime é utilizado em países produtores cujas empresas estatais são atuantes na atividade de $\mathrm{E} \& \mathrm{P}^{172}$.

Esclarece ainda a autora que no Brasil existem os seguintes regimes jurídicos aplicáveis na exploração de petróleo e gás:

a) concessão, prevista na Lei $n^{\circ} 9.478 / 97$ para a exploração de petróleo em todas as áreas, excluídas as integrantes do pré-sal e as definidas como estratégicas;

b) contrato de partilha de produção, regido pela Lei $\mathrm{n}^{\mathbf{o}} 12.351 / 2010^{173}$, com as modificações legislativas posteriores, é aplicável à exploração ocorrida no présal e nas áreas definidas como estratégicas, podendo a Petrobras operar sozinha ou ser a operadora dos consórcios em caso de licitação;

c) contrato de concessão onerosa, que é regido pela Lei Federal no 12.276/2010 e é aplicável à exploração em áreas não concedidas localizadas no pré-sal.

${ }^{172}$ CARDOSO, Auta Alves. A classificação jurídica das denominadas participações governamentais na indústria de petróleo e gás, p. 96/98.

${ }^{173} \mathrm{O}$ artigo $2^{\circ}$ da Lei ${ }^{\circ} 12.351 / 2010$ define partilha de produção como sendo "regime de exploração e produção de petróleo, de gás natural e de outros hidrocarbonetos fluidos no qual o Contratado exerce, por sua conta e risco, as atividades de exploração, avaliação, desenvolvimento e produção e, em caso de descoberta comercial, adquire o direito à apropriação do custo em óleo, do volume da produção correspondente aos royalties devidos, bem como de parcela do excedente em óleo, na proporção, condições e prazos estabelecidos em contrato. 


\section{CAPÍTULO IV: A REGRA-MATRIZ DO ICMS NA EXTRAÇÃO DO PETRÓLEO}

No capítulo 2 deste trabalho, discorremos sobre a regra-matriz do ICMS mercantil e os critérios integrantes dessa norma. No capítulo anterior, esmiuçamos os principais enunciados constitucionais relativos às atividades econômicas do monopólio da União sobre o petróleo, a sua "flexibilização" com o advento da Emenda Constitucional n 9 9/95 e as participações governamentais, que são fundamentais para a contextualização do tema enfrentado neste estudo.

Com base nas considerações feitas até o momento, analisaremos, no próximo capítulo, se o legislador do Estado do Rio de Janeiro observou os limites materiais para a instituição do ICMS que tem por hipótese de incidência a extração do petróleo.

\subsection{A Lei do Estado do Rio de Janeiro $\mathrm{n}^{\circ} \mathbf{4 . 1 1 7 / 0 3}$}

Em 30 de junho de 2003, foi publicada a Lei $n^{\circ} 4.117$, do Estado do Rio de Janeiro, que alterou a Lei $n^{\circ}$ 2.657, de 26 de dezembro de 1996, mais conhecida como "Lei Noel". Referida lei prescreve a incidência do ICMS na extração do petróleo.

$\mathrm{O}$ artigo $3^{\circ}$ dessa lei estabelece que o "fato gerador" do ICMS ocorre na extração do petróleo, quando a mercadoria passar pelos pontos de medição da produção.

Tal enunciado é objeto da Ação Direta de Inconstitucionalidade $\mathrm{n}^{\circ} 3.019$, proposta pelo Procurador Geral da República, a qual não foi julgada pelo Supremo Tribunal Federal até o momento.

Na referida ação, o Governo do Estado do Rio de Janeiro sustenta, em síntese, que ocorre a transferência de propriedade do petróleo no momento em que este passa pelos pontos de medição da produção.

Nesse instante, aquilo que é da União, nos termos do artigo 176 da Constituição Federal, passaria para o domínio do concessionário, ocorrendo uma operação que implicaria uma circulação de mercadoria passível de incidência do ICMS.

A fim de verificar se o legislador ordinário estadual observou os critérios previstos na regra-matriz constitucional do ICMS, ou seja, o seu arquétipo constitucional, como assevera ROQUE ANTÔNIO CARRAZA, passamos a compor a aludida regra a partir dos enunciados-enunciados veiculados pela Lei $n^{\circ} 4.117 / 03$ : 
Lei $n^{\circ} 4117 / 03$

$1^{\circ}-\mathrm{O}$ art. $2^{\circ}$ da Lei $\mathrm{n}^{\circ} 2.657$, de 26 de dezembro de 1996, passa a vigorar com a seguinte redação, acrescido do inciso VI:

“Art. $2^{\circ}-\mathrm{O}$ imposto incide sobre:

VI - operação de extração de petróleo.”

Art. $2^{\circ}-\mathrm{O}$ art. $3^{\circ}$ da Lei $\mathrm{n}^{\circ} 2.657$, de 26 de dezembro de 1996, passa a vigorar com a seguinte redação, acrescido do inciso XVII e do $\S 10$ :

“Art. $3^{\circ}-\mathrm{O}$ fato gerador do imposto ocorre:

XVII - na extração do petróleo, quando a mercadoria passar pelos Pontos de Medição da Produção.

$\S 10$ - Os Pontos de Medição da Produção são aqueles pontos definidos no plano de desenvolvimento de cada campo nos termos da legislação em vigor, onde se realiza a medição volumétrica do petróleo produzido nesse campo, expressa nas unidades métricas de volume adotadas pela Agência Nacional do Petróleo - ANP e referida à condição padrão de medição, e onde o concessionário, a cuja expensas ocorrer a extração, assume a propriedade do respectivo volume de produção fiscalizada, sujeitando-se ao pagamento dos tributos incidentes e das participações legais e contratuais correspondentes."

Art. $3^{\circ}-\mathrm{O}$ art. $4^{\circ}$ da Lei $\mathrm{n}^{\circ} 2.657$, de 26 de dezembro de 1996, passa a vigorar com a seguinte redação, acrescido do inciso XIII e do $\S 5^{\circ}$ :

"Art. $4^{\circ}$ - A base de cálculo, reduzida em $90 \%$ (noventa por cento) se incidente o imposto sobre as prestações de serviços de transporte rodoviário intermunicipal de passageiros executados mediante concessão, permissão e autorização do Estado do Rio de Janeiro, inclusive os de turismo, é:

XIII - No caso do inciso XVII do art. $3^{\circ}$, o preço de referência do petróleo.

$\S 5^{\circ}$ - O preço de referência a ser aplicado a cada período de apuração ao petróleo produzido em cada campo durante o referido período, em reais por metro cúbico, na condição padrão de medição, será igual à média ponderada dos seus preços de venda praticados pelo concessionário, em condições normais de mercado, ou ao seu preço mínimo estabelecido pela ANP, aplicando-se o que for maior"

Art. $4^{\circ}-\mathrm{O}$ art. 14 da Lei $\mathrm{n}^{\circ} 2.657$ de 26 de dezembro de 1996, passa a vigorar com a seguinte redação, acrescido do inciso XXI:

“Art. 14 - A alíquota do imposto é:

XXI - na operação de extração de petróleo: 18\% (dezoito por cento)"

Art. $5^{\circ}-\mathrm{O}$ art. 15 da Lei $\mathrm{n}^{\circ} 2.657$, de 26 de dezembro de 1996, passa a vigorar com a seguinte redação:

"Art. 15 - Contribuinte é qualquer pessoa, física ou jurídica, que realize, com habitualidade ou em volume que caracterize intuito comercial, operação de circulação de mercadoria ou prestação de serviços descritos com o fato gerador do imposto, observado o disposto no $\S 2^{\circ}$ deste artigo.

$\S 1^{\mathrm{o}}$ - Incluem-se entre os contribuintes do imposto:

I - O comerciante, o industrial, o produtor e o extrator, inclusive de petróleo;” 
Art. $6^{\circ}-\mathrm{O}$ art. 30 da Lei $\mathrm{n}^{\circ} 2.657$, de 26 de dezembro de 1996, passa a vigorar com a seguinte redação, acrescido da alínea "l", no inciso I:

“Art. 30 - Para efeito de cobrança do imposto e definição do estabelecimento responsável, considera-se:

I - local da operação:

1) aquele de onde o petróleo tenha sido extraído."

Art. $7^{\mathbf{o}}$ - O estabelecimento que comercializar, dentre outras mercadorias, combustíveis e lubrificantes, deverá adotar inscrição e regime de escrituração específica para esta atividade.

\section{(I) Antecedente:}

> critério material: realizar operações de extração de petróleo;

critério espacial: local onde o petróleo é extraído;

$>$ critério temporal: momento em que o petróleo passa pelos pontos de medição de produção;

\section{(II) Consequente:}

\section{critério pessoal:}

a) sujeito ativo: Estado do Rio de Janeiro

b) sujeito passivo: o extrator de petróleo

$>$ critério quantitativo:

a) alíquota: $18 \%$

b) base de cálculo: o preço de referência do petróleo

\subsection{Da análise do critério material: realizar operações com extração de petróleo}

Fixadas as premissas acerca do critério material da hipótese de incidência do ICMS, passa-se a analisar se, no momento em que o petróleo passa pelos pontos de medição de produção, como prevê o artigo $3^{\circ}$ da Lei do Estado do Rio de Janeiro $n^{\circ}$ 2.657/1996, com a redação dada pelo artigo $2^{\circ}$ da Lei $n^{\circ} 4.117 / 03$, ocorre a transferência de propriedade do petróleo da União para o concessionário.

Conforme já demonstrado, a Emenda Constitucional nº 9/95 deu nova redação ao parágrafo primeiro do artigo 177 da Constituição Federal, ampliando as atividades econômicas submetidas ao monopólio da União, bem como incluiu o parágrafo $2^{\circ}$, 
admitindo a contratação de empresas estatais e privadas para a realização das atividades monopolísticas, observadas as condições estabelecidas em lei.

Com base nessa permissão constitucional, foi editada a Lei $\mathrm{n}^{\circ} 9.478 / 97$, estatuindo, no seu artigo 26 , que

\begin{abstract}
A concessão implica, para o concessionário, a obrigação de explorar, por sua conta e risco e, em caso de êxito, produzir petróleo ou gás natural em determinado bloco, conferindo-lhe a propriedade desses bens, após extraídos, com os encargos relativos ao pagamento dos tributos incidentes e das participações legais ou contratuais correspondentes.
\end{abstract}

Percebe-se, dessa forma, que por uma questão de política energética, a Lei $\mathrm{n}^{\circ}$ 9.478/97, visando incentivar os investimentos para o aumento da produção de petróleo no Brasil, garantiu que esse recurso mineral explorado é de propriedade do concessionário.

Diante dessa situação, o governador do Estado do Paraná ingressou com a ADIN n ${ }^{\circ}$ 3.723-9, questionando, dentre outros dispositivos da Lei $\mathrm{n}^{\circ}$ 9.478/97, o referido artigo 26, alegando, basicamente, que a atribuição ao concessionário da propriedade do petróleo resultaria na quebra do monopólio estabelecido no artigo 177, conferindo a esse recurso mineral o mesmo tratamento dado aos demais recursos previstos no artigo 176, em relação aos quais inexiste monopólio.

A referida ADIN foi julgada improcedente pelo Supremo Tribunal Federal em 16/03/05. De acordo com o voto proferido pelo Ministro Eros Grau, há uma distinção entre o monopólio da atividade prevista no artigo 177 da Carta Maior e a propriedade exclusiva da União em relação aos demais recursos minerais previstos no seu artigo 20:

O conceito de monopólio efetivamente não se presta a explicitar características
de propriedade, de modo que não cabe aludirmos a monopólio de propriedade.
(...)
A Constituição do Brasil enumera, em seu art. 177, atividades que constituem
monopólio da União (v.g. pesquisa e lavra das jazidas de petróleo e gás natural,
refinação de petróleo, importação e exportação de produtos derivados de
petróleo, transporte marítimo de petróleo bruto etc.) e, em seu art. 20, os bens
que são de sua exclusiva propriedade (terras devolutas, ilhas fluviais, mar
territorial, terrenos de marinha, recursos minerais, sítios arqueológicos etc.).
Atividades e bens, uma coisa distinta da outra.
Por isso não é adversa à Constituição a existência ou desenvolvimento de uma
atividade econômica sem que a propriedade do bem empregado no processo
produtivo ou comercial seja concomitantemente detida pelo agente daquela
atividade.

Restou, portanto, assentado no Supremo Tribunal Federal, que o artigo 26 da lei em questão não violou o regime do monopólio previsto no artigo 177 da Carta Maior, com a 
alteração dada pela Emenda Constitucional $n^{\circ} 9 / 95^{174}$, sendo aplicável à produção do petróleo a parte final do artigo 176, segundo o qual é “[...] assegurado ao concessionário o resultado do produto da lavra".

Em razão da declaração de constitucionalidade do artigo 26 da Lei $n^{\circ}$ 9.478/97 pelo Supremo Tribunal Federal, o Estado do Rio de Janeiro sustenta, na ADIN nº 3.019, que

[...] resta indiscutível que a extração do petróleo é fato que confere ao concessionário a propriedade do petróleo extraído, petróleo que antes integrava a jazida e pertencia à União, portanto, a passagem pelo ponto de medição, que consubstancia o momento exato da extração, é fato translativo da propriedade.

Com base nessa premissa, defende o Estado do Rio de Janeiro que ocorre operação relativa à circulação jurídica de mercadoria apta à incidência do ICMS.

Passaremos, então, a enfrentar tal questão. Para tal proposito, responderemos às seguintes indagações: (i) a extração do petróleo se configura como operação relativa à circulação de mercadoria? (ii) qual a acepção do termo "conferência" a que alude o artigo 26 da Lei $n^{\circ} 9.478 / 97$ ?

\subsubsection{Petróleo como bem público da União}

Como já mencionado, a atual Constituição Federal definiu, expressamente, "os recursos minerais, inclusive os do subsolo" como bens da União (artigo 20, inciso X). De acordo com JOSE CRETELLA JUNIOR, essa expressão significa "incluem-se entre os bens", "pertencem", "são do domínio público" que surgem entre os bens públicos da União $^{175}$.

A Carta Maior prescreve também, no seu artigo 176 caput, que a União detém a propriedade das jazidas e, na sua parte final, garante ao concessionário a propriedade do produto da sua lavra.

\footnotetext{
${ }^{174}$ Segundo GILBERTO BERCOVICI, o artigo 26, caput, da Lei no 9478/97 é inconstitucional, pois viola o disposto nos artigos 20, IX, e 177 da Constituição. Segundo o autor, o petróleo e o gás natural são bens inalienáveis da União, bens de uso especial, como os demais recursos minerais. A diferença entre o regime jurídico dos recursos minerais em geral (artigo 176) e o regime jurídico do petróleo, gás natural e minérios nucleares (artigo 177) é, justamente, o fato destes últimos terem sido monopolizados pela União. A autorização constitucional manifestada no artigo 176, caput de que o produto da lavra mineral é propriedade do concessionário é uma exceção da alienabilidade ao regime jurídico dos bens minerais, por isso é expressa constitucionalmente. A regra é a inalienabilidade dos recursos minerais" (Direito Econômico do Petróleo e dos Recursos Minerais, p. 295).

${ }^{175}$ JUNIOR, José Cretella. Comentários à Constituiçãa, vol. III. $2^{\mathrm{a}}$ ed. Rio de Janeiro: Forense, 1991, p. 1189.
} 
Inicialmente é importante conceituar o petróleo como recurso mineral ${ }^{176}$, que se insere entre os bens pertencentes à União. Trata-se, portanto, de um bem público submetido ao regime de dominialidade pública.

Deveras, o regime de dominialidade publica não é equivalente ao de propriedade privada. Como bem assevera ODETE MEDAUAR ${ }^{177}$, os bens públicos têm titulares, mas os direitos e deveres dele resultantes, exercidos pela Administração, não decorrem do direito de propriedade no sentido tradicional. De acordo com a autora, os bens públicos devem ter destinação que atenda ao interesse público, de forma direta ou indireta. A afetação, explícita ou tácita, atribui destinação específica ao bem. Sobre os bens públicos incidem predominantemente preceitos do direito administrativo, que formam um regime de direito público, diferente do regime aplicado aos bens pertencentes aos particulares.

Exposto o regime a que se submete o petróleo, faz-se necessário apontar brevemente as principais características dos bens públicos, a fim de identificar que tipo de bem público consiste o petróleo. Para tal desiderato, valemo-nos da classificação adotada pelo artigo 99 do Código Civil de 2002. De acordo com esse enunciado, são bens públicos:

a) os de uso comum do povo, tais como rios, mares, estradas, ruas e praças (inciso I): São os bens destinados ao uso indistinto de todos. O povo é beneficiário direto e imediato desses bens. Em regra, o uso é gratuito, mas pode ser remunerado, conforme estabelece o artigo 103 do Código Civil ${ }^{178}$ (exemplo: pedágios em estradas e ancoragem em portos);

b) os de uso especial, tais como edifícios ou terrenos destinados a serviço ou estabelecimento de administração federal, estadual, territorial ou municipal, inclusive os de suas autarquias (inciso II): Esses bens são destinados ao uso da Administração para a consecução dos seus objetivos, como os imóveis onde estão

\footnotetext{
${ }^{176} \mathrm{O}$ artigo $20, \S 1^{\circ}$, da Constituição Federal classificou o petróleo como recurso mineral, ao assegurar "nos termos da lei, aos Estados, ao Distrito Federal e aos Municípios, bem como a órgãos da administração direta da União, participação no resultado da exploração de petróleo ou gás natural, de recursos hídricos para fins de geração de energia elétrica e de outros recursos minerais no respectivo território, plataforma continental, mar territorial ou zona econômica exclusiva, ou compensação financeira por essa exploração".Da mesma forma, o Ministro Carlos Ayres Brito reconhece o petróleo (substância orgânica) como recurso mineral no voto proferido na ADIN 3.273: "A Carta-cidadã, fiel à proposição kelseniana de que o Direito constrói suas próprias realidades, optou por ignorar as discussões geológicas e geofísicas sobre a distinção entre hidrocarbonetos fluidos e gasosos (que seriam substâncias orgânicas) e os recursos minerais propriamente ditos (que teriam a natureza de substâncias inorgânicas). Isto para fazer destes últimos (recursos minerais) o gênero no qual os dois primeiros se encartariam. As três tipologias fundindo-se, em princípio, numa única realidade normativa ou figura de Direito, sob o nome abrangente de 'recursos minerais"”.

${ }^{177}$ MEDAUAR, Odete. Direito Administrativo Moderno. 16 ${ }^{a}$ ed. São Paulo: Revista dos Tribunais, 2012. p. 268.

178 "Art. 103. O uso comum dos bens públicos pode ser gratuito ou retribuído, conforme for estabelecido legalmente pela entidade a cuja administração pertencerem.”.
} 
instaladas as repartições públicas, os bens móveis utilizados na prestação dos serviços públicos (veículos oficiais, materiais de consumo, navios de guerra), as terras dos silvícolas, os mercados municipais, os teatros públicos, os cemitérios públicos. Tais bens não comportam uso geral, comum, aberto a todos. Além disso, o uso de parte desses bens por particulares depende de consentimento da Administração, como assevera ODETE MEDAUAR ${ }^{179}$;

c) os dominicais, que constituem o patrimônio das pessoas jurídicas de direito público, como objeto de direito pessoal, ou real de cada uma dessas entidades (inciso III): Tais bens não possuem destinação pública determinada, motivo pelo qual podem ser utilizados pelo Poder Público para a obtenção de renda ou outro fim de interesse público ou dos particulares, como as terras devolutas, os terrenos da marinha e os bens móveis inservíveis. ODETE MEDAUAR assevera, com propriedade, que esses bens não estão submetidos ao regime privado, mas sim ao regime público, só podendo ser alienados desde que observadas as exigências legais, razão pela qual não são adequadas as expressões "bens do domínio privado do Estado" ou "bens do patrimônio disponível" ${ }^{180}$.

Os bens públicos podem ser afetados ou desafetados. A afetação é a atribuição a um bem público de sua destinação específica, que pode ocorrer de forma explícita (lei, ato administrativo e o registro do projeto de loteamento) ou implícita, quando a Administração Pública utiliza um bem para determinada finalidade sem manifestação formal (casa doada onde foi instalada uma biblioteca pública ${ }^{181}$ ). Os bens de uso comum do povo e de uso especial são bens afetados, ao passo que os bens dominicais são bens não afetados a qualquer destino público.

Já a desafetação é a mudança da destinação do bem, ou seja, a inclusão dos bens de uso comum do povo e de uso especial à categoria dos bens dominicais para possibilitar a alienação.

\footnotetext{
${ }^{179}$ MEDAUAR, Odete. Direito Administrativo Moderno, p. 272.

180 “[...] tais bens aparecem tratados sob a rubrica de bens do domínio privado do Estado ou bens do patrimônio disponível. Com tais expressões se pretenderia significar que os vínculos da Administração com os bens dominicais seriam semelhantes aos vínculos do particular com os bens do seu patrimônio, em especial pela facilidade de alienação; mencione-se também que seu regime seria precipuamente privado. Deve-se notar, de início, ainda uma vez, que as citadas denominações podem levar a equívocos sobre o regime jurídico de tais bens e a facilidade de disposição. Por outro lado, os bens dominicais integram os bens públicos, como diz o art. 99 do Código Civil; sendo assim seu regime jurídico é essencialmente público; só podem ser alienados observadas as exigências de lei, pois assim determina o art. 101 do Código Civil" (Ibid., p. 272/273).

${ }^{181}$ Ibid., p. 273.
} 
As principais características dos bens públicos dizem respeito à alienabilidade, impenhorabilidade, imprescritibilidade.

a) Inalienabilidade: Nos termos do que dispõe o artigo 100 do Código Civil, os bens de uso comum e de uso especial são inalienáveis enquanto conservarem tal qualificação, ou seja, enquanto estiverem afetados a tais destinos. LÚCIA VALLE FIGUEIREDO esclarece que a inalienabilidade é absoluta para os bens de uso comum do povo, tal como o meio ambiente ecologicamente equilibrado, e relativa para os bens de uso especial, que poderá ser alienado quando o bem for desafetado ${ }^{182}$.

O artigo 101 do mesmo diploma prescreve, por sua vez, que os bens públicos dominicais podem ser alienados, observadas as exigências da lei. Tais exigências estão previstas nos artigos 17 e 19 da Lei nº 8.666/93: interesse público, prévia avaliação, autorização legislativa para os bens imóveis e licitação.

b) Impenhorabilidade: A impenhorabilidade dos bens públicos decorre da própria inalienabilidade, prevista no artigo 100 do Código Civil, razão pela qual tais bens, inclusive os dominicais, não podem ser gravados com direitos reais de garantia, como bem elucida MARIA SYLVIA ZANELLA DI PIETRO ${ }^{183 .}$

c) Imprescritibilidade: Os bens públicos são imprescritíveis, não sendo suscetíveis de usucapião, conforme estabelece o artigo 102 do Código Civil e a própria Constituição Federal, nos artigos $183 \$ 3^{\circ}$ e 191, parágrafo único, que veda o usucapião de imóveis públicos.

Expostas as principais características dos bens públicos, cumpre-nos identificar a que modalidade de bem público se enquadram os recursos minerais (dominical ou de uso especial). Nesse ponto, há divergência doutrinária.

\footnotetext{
${ }^{182}$ FIGUEIREDO, Lúcia Valle. Curso de Direito Administrativo. $8^{a}$ ed. São Paulo: Malheiros, 2006. p. 580 .

183 "A impossibilidade de instituição de direitos reais, como penhor e garantia, sobre os bens dominicais, constitui decorrência lógica da regra do artigo 100 da Constituição, que estabelece processo especial de execução contra a Fazenda Pública, excluindo, implicitamente, a penhora sobre qualquer tipo de serviço público pertencente às pessoas jurídicas de direito público. Não podendo ser penhorados, os bens públicos também não podem ser dados em garantia, porque, no momento da execução, tem que ser utilizado obrigatoriamente o processo dos precatórios estabelecido pelo dispositivo constitucional. Fica derrogado, em consequência, com relação aos vens públicos dominicais, o artigo 1.420 do Código Civil, segundo o qual somente aquele que pode alienar poderá empenhar, hipotecar ou dar em anticrese; só os bens que podem alienar poderão ser dados em penhor, anticrese ou hipoteca. Desse modo, embora os bens dominicais possam ser alienados, não podem ser dados em penhor, anticrese ou hipoteca." (PIETRO, Maria Sylvia Zanella. Uso privativo do bem público sobre particular. $2^{\mathrm{a}}$ ed. São Paulo: 2010. p. 9 ).
} 
JOSE CRETELLA JUNIOR ${ }^{184}$ defende que os recursos minerais, situados na superfície e no subsolo, são bens públicos dominicais da União, razão pela qual a competência para legislar sobre as riquezas do subsolo compete exclusivamente à União. CELSO ANTÔNIO BANDEIRA DE MELLO ${ }^{185}$ também classifica as jazidas como bens dominicais.

GILBERTO BERCOVICI, por sua vez, defende que o petróleo e os recursos minerais são bens públicos de uso especial. São bens indisponíveis porque possuem uma destinação pública definida constitucionalmente: a exploração e o aproveitamento dos seus potenciais. De acordo com o autor,

[...] a exploração dos recursos minerais está vinculada aos objetivos fundamentais dos artigos 3ㅇ, 170 e 219 da Constituição de 1988, ou seja, o desenvolvimento, a redução das desigualdades e a garantia da soberania econômica nacional. Trata-se de um patrimônio público irrenunciável ${ }^{186}$.

Compartilham desse mesmo entendimento ALEXANDRE DE MORAES ${ }^{187} \mathrm{e}$ MARIA SYLVIA ZANELLA DI PIETRO ${ }^{188}$. De acordo com a autora, os recursos minerais são bens públicos de uso especial, porquanto se encontram fora do comércio jurídico de direito privado, razão pela qual tais bens não podem ser alienados, penhorados ou adquiridos em usucapião, de modo que as relações estabelecidas devem ser regidas pelas regras de direito público. Sustenta ainda a autora que os recursos minerais não podem ser desafetados de fins públicos nem alienados por determinação da própria Constituição Federal, o que impede a legislação ordinária de autorizar a venda.

No nosso entendimento, os recursos minerais, dentre os quais o petróleo, se enquadram na categoria de bens públicos de uso especial, porque a própria Constituição

\footnotetext{
${ }^{184}$ CRETElla JUNIOR, José. Comentários à Constituição de 1988. Rio de Janeiro: Forense, 1991. 3 v. p.1.211.

${ }^{185}$ MELLO, Celso Antônio Bandeira. Curso de Direito Administrativo. 25 a ed. São Paulo: Malheiros, 2008. p. 908.

${ }^{186}$ BERCOVICI, Gilberto. Direito Econômico do Petróleo e dos Recursos Minerais, p. 291.

187 “As jazidas de petróleo, gás natural e outros hidrocarbonetos fluidos são bens públicos de uso especial, 'uma vez que têm uma destinação pública destinada constitucionalmente, qual seja, a exploração e aproveitamento de seus potenciais; bem como, sob o seu aspecto jurídico, esses bens públicos são do domínio público do Estado" (MORAES, Alexandre. Regime Jurídico da Concessão para Exploração do Petróleo e Gás Natural.).

${ }^{188}$ PIETRO, Maria Sylvia Zanella. Parecer inédito sobre a CFEM, apud HERNANDEZ, Fernanda Guimaraes. Compensação financeira para exploração de recursos minerais - Regra matriz de incidência. Tese (Doutorado em Direito) - Universidade de São Paulo, 2013, p. 20.
} 
Federal estabelece, no seu artigo 176, a sua destinação: a exploração e o seu aproveitamento, que visa a proteção do interesse público e da soberania nacional.

Logo, não é possível classificar o petróleo como bem público dominical, passível de ser alienado pela União, eis que esse ente federativo não pode dele dispor livremente, motivo pelo qual não é possível enquadrá-lo no conceito de mercadoria. Nesse exato sentido, vale citar trecho do voto proferido pelo Ministro Marco Aurélio na ADIN 3273:

Sendo petróleo um bem público especial, o Estado não pode dele dispor ao livre arbítrio. Primeiro, em razão de possuir destinação específica, que é atender as necessidades de consumo do mercado interno, conforme previsão expressa do artigo 177, $\S 2^{\circ}$, inciso I, da Constituição Federal. Segundo, pelo fato de o petróleo não se caracterizar como uma simples mercadoria, uma commodity, porque é um bem estratégico que se traduz em soberania.

(...)

Ora, classificar o petróleo como bem público dominical significaria dizer que a União poderia dispor dessa propriedade sempre que bem entendesse, ou ainda, que poderia aliená-lo sempre que desejasse, observados necessariamente os requisitos previstos em lei. Esse não é o alcance fidedigno da Carta de 1988, que a todos submete.

Assim, pela análise dos enunciados constitucionais que dispõem sobre a mineração, concluímos que o petróleo não se amolda ao conceito de mercadoria, ou seja, bem móvel destinado $^{189}$ à mercancia (venda ou revenda), justamente porque se trata de um bem público de uso especial (submetido, portanto, ao regime de direito público e não privado), inalienável por natureza e insuscetível de desafetação por determinação constitucional.

Situação semelhante a ora debatida (incidência do ICMS sobre o fornecimento domiciliar de água potável) foi, recentemente, apreciada pelo Supremo Tribunal Federal quando do julgamento do Recurso Extraordinário 607056.

Naquela ocasião, o Ministro Relator DIAS TOFFOLI corretamente afirmou que (i) a água bruta é um bem público de uso comum do povo, não podendo, portanto, ser qualificado como mercadoria ${ }^{190}$ mesmo após sofrer um tratamento químico necessário para

\footnotetext{
${ }^{189}$ Como assevera PAULO DE BARROS CARVALHO, “a natureza mercantil do produto não está, absolutamente, entre os requisitos que lhe são intrínsecos, mas na destinação que se lhe dê (Direito Tributário, linguagem e método. p. 730).

${ }^{190}$ Nesse mesmo sentido, ROQUE ANTÔNIO CARRAZA assevera: “[...] a água em estado bruto não é uma mercadoria, porquanto não se destina ao comércio. É um bem que a todos pertence (bem público) e integra o patrimônio da Nação. De fato, o art. 20, III, da CF coloca entre os bens da União 'os lagos, rios e quaisquer correntes de água em terrenos de seu domínio, ou que banhem mais de um Estado, sirvam de limites com outros países ou se estendam a território estrangeiro ou dele provenham'. Já o art. 26, I do mesmo Diploma Excelso insere entre os bens dos Estados-Membros 'as águas superficiais ou subterrâneas, fluentes, emergentes e em depósito’ que não estiverem no domínio da União. Muito bem, na medida em que as águas são incontendivelmente bens públicos, segue-se que não são mercadorias, não podendo, por isso, ensejar tributação por meio do ICMS. Ademais, neste estado natural a água é insuscetível de avaliação econômica, circunstância que, de per si, afasta a incidência do ICMS”. (ICMS, p. 193).
} 
o consumo e (ii) a concessionária não detém disposição sobre esse bem, mas apenas outorga do direito de uso:

\begin{abstract}
Evidencia-se, assim, que os conceitos de "operação", "circulação" e "mercadoria" permanecem umbilicalmente ligados, devendo o intérprete das leis e os aplicadores do ICMS tomá-los em suas concepções jurídicas para efeito da caracterização de sua incidência. No caso, estão ausentes os elementos que adjetivam o aspecto material da hipótese de incidência do ICMS, quais sejam: "circulação" e "mercadoria", na medida em que as concessionárias - promotoras da operação de fornecimento de água - não detêm poderes jurídicos de disposição sobre ela, tampouco podem dar destinação comercial à água, dada a sua natureza de bem público.

Esse entendimento é corroborado pelo art. 18 da Lei no 9.433/97, que "institui a Política Nacional de Recursos Hídricos", ao deixar claro que a concessão do serviço público de distribuição de água canalizada constitui mera outorga dos direitos de uso, não implicando a alienação das águas, uma vez que se trata de bem de uso comum do povo, inalienável.
\end{abstract}

Portanto, considerando que o petróleo é um bem público inalienável e, portanto, insuscetível de ser qualificado como mercadoria, não se configura como possível a sua circulação jurídica, ou seja, a transferência de titularidade desse bem, pertencente à União, ao concessionário no momento da sua extração.

\title{
4.2.2. Extração como processo de produção do petróleo
}

De acordo com o artigo $6^{\circ}$, inciso XVI, da Lei $\mathrm{n}^{\circ}$ 9.478/97, a lavra, sinônimo de produção, é definida como o conjunto de operações coordenadas de extração de petróleo ou gás natural de uma jazida e de preparo para a sua movimentação.

Portanto, a extração, assim como o preparo, são atividades materiais necessárias para a produção do petróleo. Logo, somente após a extração, o petróleo passa a existir como bem individualizado. Antes dessa etapa produtiva, o petróleo não existe como um produto em si.

O que a União detém, até esse momento, são apenas os depósitos ou jazidas, ou seja, os potenciais encontrados no subsolo e na plataforma continental, que podem ou não conter petróleo.

Entretanto, a simples produção de um bem ou produto não constitui hipótese de incidência do ICMS, justamente porque ainda não foi introduzido no ciclo de circulação, não podendo ser qualificado como mercadoria. Segundo MARCO AURÉLIO GRECO ${ }^{191}$,

${ }^{191}$ GRECO, Marco Aurélio. ICMS - Exigência em relação à extração do petróleo. Revista Dialética de Direito Tributário. São Paulo, nº 100, jan/2004. p. 127. 
com a produção, o contribuinte apenas "dá vida" ao produto, mas ainda não o colocou em circulação, porque antecede o próprio ciclo.

Se circulação jurídica existisse na produção do petróleo, observa ALCIDES JORGE COSTA ${ }^{192}$, também estariam sujeitas ao ICMS a produção agrícola ou pecuária ou qualquer indústria extrativa, como a da borracha, independentemente da ocorrência de qualquer operação relativa à circulação de mercadorias. De acordo com a posição do autor, com a qual aderimos, se possível fossem essas incidências, o ICMS seria um imposto sobre produção, em total descompasso com a hipótese de incidência prevista constitucionalmente.

Nesse sentido, o Supremo Tribunal Federal já rechaçou a exigência do antigo ICM na transferência de cana-de-açúcar, de produção própria, entre o local do plantio e o local em que se encontra o maquinário da usina, justamente por entender que não há, no deslocamento da matéria-prima entre o estabelecimento produtor para o estabelecimento industrial da mesma empresa (consideradas independentes por alguns Estados), circulação jurídica de mercadoria, mas mero processo produtivo, conforme se extrai da passagem do voto proferido pelo Ministro RAFAEL MAYER:

Os atos internos, os graus de processamento no interior do estabelecimento não podem ser elementos de circulação econômica e jurídica, pois são simples atos físicos ou materiais do processo produtivo e não dão causa à incidência do imposto. Não pode, portanto, o Estado considerar como estabelecimento autônomo a unidade empresarial, em determinado estágio produtivo, que não tem por missão promover a saída, pois não é a saída o simples degrau do processo produtivo.

Sem dúvida, os preceitos impugnados investem contra as normas constitucionais e complementares ao seccionar o processo de produção para tributar um momento de alteração ou deslocamento físico de insumos ou materiais que não se destinam diretamente ao ingresso no meio circulante da economia (RP 1181; g.n.).

Nesse mesmo diapasão foi o entendimento do Ministro OSCAR CORREA proferido na Representação $\mathrm{n}^{\circ} 1355$ :

Ora não é aceitável que se distingam estabelecimentos do mesmo contribuinte, ainda que representando etapa do processo produtivo - e, por isso em circulação apenas física, ou para integração econômica - como se pudesse agregar valor que o outro estabelecimento do mesmo contribuinte devesse considerar.

${ }^{192}$ COSTA, Alcides Jorge. Estudos sobre IPI, ICMS, ISS. ICMS. Operações com petróleo - Projeto de Lei do Estado do Rio de Janeiro - fato gerador: extração do petróleo - extensão territorial da competência tributária. São Paulo: Dialética, 2009. p. 71-79. 
O que há de se aguardar é a operação de circulação de mercadorias - isto é, quando, após percorrer o iter produtivo da unidade produtiva (da empresa), ainda que integrando elementos (materiais, produtos semi-acabados, e demais de um estabelecimento - só aí então incida o imposto porque só aí se verifica operação de mercadoria tributável.

Enquanto o produto se completa, se integra, com a participação de estabelecimentos de uma mesma unidade autônoma (em geral, da própria empresa jurídica) não há em operação de circulação de mercadorias.

A menos que o estabelecimento não remeta a outro da mesma unidade o seu produto, mas o transfira a outra empresa - de outro proprietário - quando então se terá verificado igualmente a operação sobre a qual incide a exação - e isto porque agiu como autônomo.

Ademais, o STF, ao julgar o Recurso Extraordinário $\mathrm{n}^{\circ}$ 158.834-SP, já se manifestou em outro caso semelhante, reconhecendo a ilegitimidade da cobrança do ICMS no momento em que as mercadorias produzidas pelo próprio estabelecimento integram o seu ativo fixo:

ICMS - PRODUÇÃO - ATIVO FIXO - SAÍDA - FICÇÃO JURÍDICA. Mostram-se inconstitucionais textos de convênio e de lei local - Convênio ${ }^{\circ}$ 66/88 e Lei no 6.374/89 do Estado de São Paulo - reveladores, no campo da ficção jurídica (saída), da integração, ao ativo fixo, do que produzido pelo próprio estabelecimento, como fato gerador do ICMS.

Vale transcrever, por oportuno, excerto do voto proferido pelo Relator Ministro SEPÚLVEDA PERTENCE no referido acórdão:

[...] c: de fato, se o deslocamento físico da matéria-prima entre unidades de uma mesma empresa não constituía, no regime pretérito, operação relativa à circulação de mercadorias, é no mínimo razoável a assertiva de que, na sistemática atual, a integração no ativo fixo de bens produzidos no próprio estabelecimento não configura hipótese de incidência que possa derivar da matriz constitucional do ICMS (art. 155, I, b).

Portanto, a atividade de extração representa apenas um processo de produção do petróleo em seu estado bruto, realizada exclusivamente pelo concessionário extrator. Esse produto ainda não está apto a circular juridicamente, pois não pode ser enquadrado, nesse momento, como mercadoria.

Em que momento então esse produto entrará em circulação? A resposta a essa indagação merece reflexão.

Deveras, ao contrário do que pensa o inconsciente popular, o petróleo extraído diretamente das rochas não emerge à superfície pronto para utilização industrial, possuindo várias impurezas misturadas a ele. Por esse motivo, após a extração, o petróleo precisa 
passar por um processo prévio de beneficiamento, denominado refino ou refinação. Nesse sentido, confira-se o disposto no inciso V da Lei no 9.478/97: "V - Refino ou Refinação: conjunto de processos destinados a transformar o petróleo em derivados de petróleo(...)".

Assim, para a obtenção dos seus derivados, em geral o petróleo é submetido a um processo de refino, chamado de destilação fracionada ${ }^{193}$. Confira-se abaixo ilustração ${ }^{194}$ sobre o aludido processo:

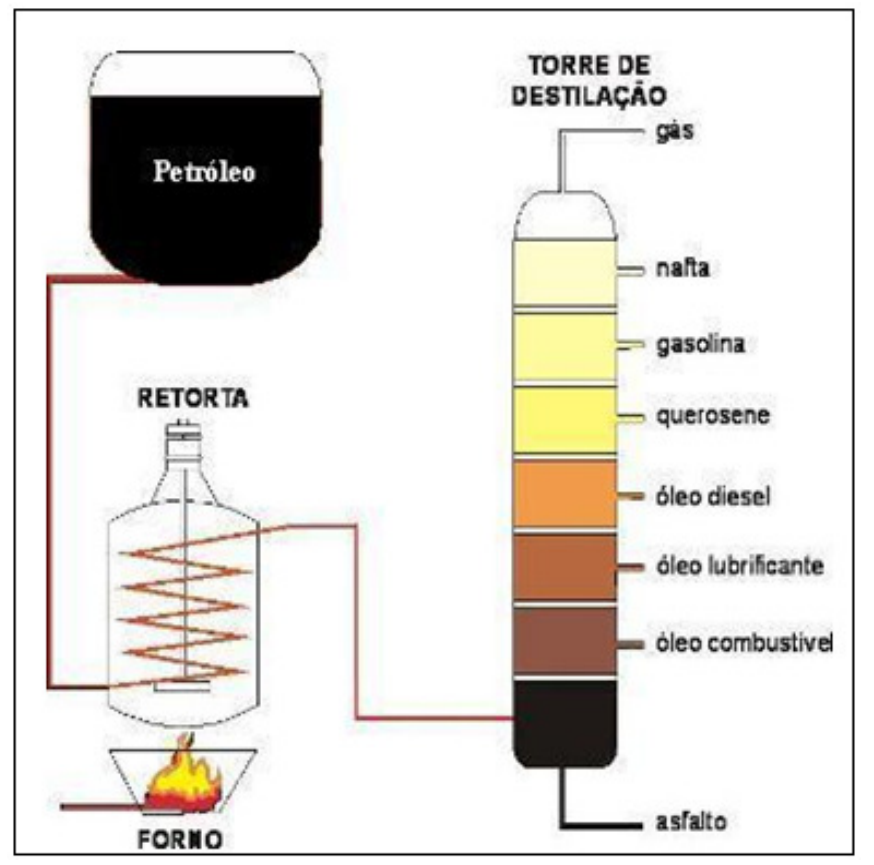

MARIA D’ASSUNÇÃO COSTA corrobora o até então exposto no sentido de que é pela atividade de refino que se obtêm os derivados do petróleo, que serão postos em circulação:

Refinar abrange um "conjunto de processos destinados a transformar o petróleo em derivados de petróleo", enquanto o processamento de gás natural compreende os "conjuntos de operações destinadas a permitir o seu transporte, distribuição e utilização". É inegável que são atividades industriais distintas mas com a mesma

\footnotetext{
${ }^{193}$ A destilação fracionada é utilizada na separação dos componentes do petróleo. O petróleo é uma substância oleosa, menos densa que a água, formado por uma mistura de substâncias. O petróleo bruto é extraído do subsolo da crosta terrestre e pode estar misturado com água salgada, areia e argila. Por decantação separa-se a água salgada, por filtração a areia e a argila. Após esse tratamento, o petróleo é submetido a um fracionamento para separação de seus componentes, por destilação fracionada. As principais frações obtidas na destilação do petróleo são: fração gasosa, na qual se encontra o gás de cozinha; fração da gasolina e da benzina; fração do óleo diesel e óleos lubrificantes, e resíduos como a vaselina, asfalto e piche. ${ }^{194}$ Disponível em: <http://www.brasilescola.com/quimica/centrifugacao-sifonagem-destilacao.htm>. Acesso em: 05 Out 2013.
} 
finalidade, ou seja, possibilitar a comercialização dos produtos refinados e/ou processados aos usuários $^{195}$.

Em suma, entendemos que inexiste circulação jurídica no momento em que o petróleo é extraído da jazida. Esse instante representa apenas o momento em que esse bem (e não mercadoria, como exposto alhures) passa a existir como produto, que ainda não integra o ciclo econômico.

Prosseguindo na análise do critério material eleito pelo legislador estadual, será analisada, a seguir, qual a natureza jurídica do contrato de concessão da exploração de petróleo, bem como o objeto desse contrato.

Essa análise se mostra fundamental para o presente trabalho, pois para que um negócio jurídico se configure operação mercantil é mister que seja regido pelo direito privado, tenha por finalidade o lucro e tenha por objeto uma mercadoria, como afirma ROQUE ANTÔNIO CARRAZA:

Enfim, para que um ato jurídico configure operação mercantil é mister que: a) seja regido pelo direito comercial; b) venha praticado num contexto de atividades empresariais; c) tenha por finalidade, pelo menos em linha de princípio, o lucro (resultados econômicos positivos); e d) tenha por objeto uma mercadoria ${ }^{196}$.

\subsubsection{Da natureza jurídica do contrato de concessão de exploração de petróleo}

A Administração Pública pode figurar como parte em duas espécies de contratos: contratos de direito privado da Administração e os contratos administrativos.

Os primeiros regem-se pelo Direito Privado. Entre os contratos privados, pode-se mencionar a compra e venda de um imóvel, a locação de uma casa para nela se instalar uma repartição pública.

Já os contratos administrativos estão sujeitos às regras e princípios do Direito Público, sendo admitida a aplicação supletiva de normas privadas. Segundo CELSO ANTÔNIO BANDEIRA DE MELLO ${ }^{197}$, nessa modalidade contratual, a Administração pode "instabilizar" o vínculo, alterando unilateralmente o que fora pactuado a respeito das obrigações do contratante e extinguindo unilateralmente o vínculo.

\footnotetext{
${ }^{195}$ COSTA, Maria D’ Assunção. Comentários à Lei do Petróleo, p. 265.

${ }^{196}$ CARRAZA, Roque Antônio. ICMS, p. 44.

${ }^{197}$ MELLO, Celso Antônio Bandeira. Curso de Direito Administrativo, p. 605
} 
Deveras, nos contratos administrativos, em que estão presentes as cláusulas exorbitantes ${ }^{198}$, o Poder Público pode alterar unilateralmente o contrato, independentemente da anuência da outra parte, desde que a intervenção seja necessária para a proteção do interesse público. Outra característica fundamental diz respeito à preservação da equação econômico-financeira do contrato ao longo da sua execução (princípio da intangibilidade do equilíbrio econômico-financeiro do contrato administrativo).

Os principais contratos administrativos são o de concessão de serviço público, o de obra pública, o de concessão de uso do domínio público, além dos contratos de fornecimento em geral e os de prestação de serviços.

No que diz respeito ao contrato de concessão para exploração de petróleo e gás natural, não há consenso na doutrina acerca da sua natureza jurídica pública ou privada. De um lado, há quem defenda que esse contrato está submetido ao regime de direito privado, eis que o seu objeto consiste em uma atividade econômica e não em prestação de serviço público ${ }^{199}$. Outra corrente sustenta que essa modalidade de concessão teria natureza publicística, na medida em que as atividades econômicas em questão são monopolizadas pela União (artigo 177), em decorrência da importância estratégica do petróleo para o país.

ALEXANDRE SANTOS DE ARAGÃO ${ }^{200}$ sustenta que esses contratos possuem natureza privada, porquanto não visam à delegação de serviços públicos, mas sim de atividades econômicas monopolizadas pelo Estado. O autor salienta, contudo, que essa característica “[...] não impede que a sua lei ou o próprio contrato prevejam obrigações e

198 Nesse sentido, CELSO ANTÔNIO BANDEIRA DE MELLO assevera: "As prerrogativas da Administração no chamado contrato administrativo são reputadas existentes por força da ordenação legal ou das cláusulas exorbitantes da avenca. Evidentemente, sua exorbitância ocorre em relação ao Direito Privado e consiste em abrigar disposições nele inadmissíveis ou incomuns" (Curso de Direito Administrativo, p. 606).

${ }^{199}$ Grande parte da doutrina entende que se trata de atividade econômica. Nesse sentido, MARIA SYLVIA ZANELLA DI PIETRO afirma que o Estado pode exercer três tipos de atividade econômica: “[...] uma que é reservada à iniciativa privada pelo artigo 173 da Constituição e que o Estado só pode executar por motivo de segurança nacional ou relevante interesse coletivo (...); outra que é considerada atividade econômica, mas que o Estado assume em caráter de monopólio, como é o caso da exploração de petróleo, de minas e jazidas, de minérios e minerais nucleares (art. 176 e art. 177 da Constituição, com as alterações introduzidas pelas Emendas Constitucionais 6 e 9, de 1995); e uma terceira que é assumida pelo Estado como serviço público e que passa a ser incumbência do poder público; a este não se aplica o art. 173, mas o art. 175 da Constituição (...) esta terceira categoria corresponde aos serviços públicos comerciais e industriais do Estado" (Direito Administrativo, p. 104).No nosso entendimento, a atividade de exploração e produção de petróleo e gás natural constitui atividade econômica, pois não se trata de uma função típica do Poder Público destinada à satisfação das necessidades básicas da coletividade (característica ínsita de serviço público), mas sim de uma atividade monopolística exercida pelo Estado.

${ }^{200}$ ARAGÃO, Alexandre Santos. O contrato de concessão de exploração de petróleo e gás. Revista Eletrônica de Direito Administrativo Econômico nº 5, fev., mar., abril. 2006. 
poderes publicistas, como, por exemplo, a obrigação de reversão dos bens empregados na exploração de petróleo ou do gás natural prevista no artigo 43, VI, da Lei do Petróleo". Em sentido contrário, MARIA D’ASSUNÇÃO $\operatorname{COSTA}^{201}$, apesar de reconhecer que a atividade em tela é econômica, reconhece que o contrato de concessão de exploração de petróleo se sujeita ao regime jurídico publicístico, porquanto o contrato em questão está subordinado a um regramento público (existência de edital com cláusulas essenciais e complementares obrigatórias por forca da lei).

Compartilha do mesmo entendimento ALEXANDRE DE MORAES ${ }^{202}$, que assevera, com apoio em Jean Rivero, que estão configurados os elementos necessários do contrato administrativo, quais sejam: a presença de uma pessoa jurídica de direito público (Agência Nacional do Petróleo) e de cláusulas exorbitantes, como as cláusulas essenciais contidas no artigo 43 da Lei $n^{\circ} 9.478 / 97^{203}$.

201 "Quanto à natureza do regime jurídico a que está submetido o contrato previsto na Lei do Petróleo (Contrato de Concessão de Uso e Exploração de Bem Público) surgiu entre os estudiosos da matéria entendimentos discordantes, o que em muito aprimora o tema, ora no sentido de fundamentá-lo com preponderância do Direito Público, ora do Direito Privado. Com base neste último regime poder-se-ia pensar de início que esse contrato é regido pelo Direito Privado por disciplinar uma atividade econômica, ou seja, com base na autonomia das partes, no consensualíssimo e na boa-fé - visto que o futuro contratado adere de livre e espontânea vontade às regras estabelecidas no edital e na legislação. E, em razão dessa autonomia, teriam as partes liberdade para dispor sobre as questões decorrentes dessa contratação. De igual forma, a exploração da atividade econômica é desenvolvida por conta e risco exclusivo do concessionário, sem direito a qualquer garantia de êxito por parte do Poder Concedente. No entanto, quando se afirma que esse contrato de concessão é regido pelo Direito Público o que se verifica é que o contrato objeto deste estudo integra um edital com cláusulas essenciais e complementares obrigatórias por força da Lei para as partes. De um lado, o Poder Concedente, representado pela ANP e, de outro, o particular (empresas isoladas ou consorciadas), vencedor da licitação, se obrigam e se vinculam ao cumprimento integral das condições licitadas e traduzidas no contrato de concessão, as quais, nesse caso, estão previstas neste artigo e nos seus incisos. Daí porque a autonomia da vontade das partes está subordinada aos ditames legais. Em verdade, o objeto contratado atende a um interesse público qualificado pela Lei do Petróleo. (...) Logo, em decorrência do regramento público a que está subordinado, o contrato de concessão pode também ser considerado um contrato regido pelo Direito Público" (COSTA, Maria D’Assunção. Comentários à Lei do Petróleo, p. 212).

${ }^{202}$ MORAES, Alexandre. Regime Jurídico da Concessão para Exploração do Petróleo e Gás Natural.

203 “Art. 43. O contrato de concessão deverá refletir fielmente as condições do edital e da proposta vencedora e terá como cláusulas essenciais:

I - a definição do bloco objeto da concessão;

II - o prazo de duração da fase de exploração e as condições para sua prorrogação;

II - o programa de trabalho e o volume do investimento previsto;

IV - as obrigações do concessionário quanto às participações, conforme o disposto na Seção VI;

$\mathrm{V}$ - a indicação das garantias a serem prestadas pelo concessionário quanto ao cumprimento do contrato, inclusive quanto à realização dos investimentos ajustados para cada fase;

VI - a especificação das regras sobre devolução e desocupação de áreas, inclusive retirada de equipamentos e instalações, e reversão de bens;

VII - os procedimentos para acompanhamento e fiscalização das atividades de exploração, desenvolvimento e produção, e para auditoria do contrato;

VIII - a obrigatoriedade de o concessionário fornecer à ANP relatórios, dados e informações relativos às atividades desenvolvidas;

IX - os procedimentos relacionados com a transferência do contrato, conforme o disposto no art. 29;

$\mathrm{X}$ - as regras sobre solução de controvérsias, relacionadas com o contrato e sua execução, inclusive a conciliação e a arbitragem internacional;

XI - os casos de rescisão e extinção do contrato; 
No nosso entendimento, a concessão de exploração e produção de petróleo e gás natural se submete ao regime jurídico de direito púbico, seja em razão do monopólio dessa atividade em favor da União, o que evidencia a imprescindibilidade desse recurso mineral para o desenvolvimento econômico do país, seja em decorrência das prerrogativas outorgadas à Administração Pública, que lhe confere uma preeminência nas relações jurídicas com os concessionários, como os incisos V, VI, VII, VII e XII do artigo 43 da Lei $n^{\circ} 9.478 / 97$.

\subsubsection{Objeto do contrato de concessão do petróleo}

Segundo OSWALDO ARANHA BANDEIRA DE MELLO, a concessão pode ser translativa ou constitutiva de direito. De acordo com o seu entendimento

[...] corresponde a ato administrativo translativo de direito a concessão pela qual o concedente atribui ao concessionário, inalterados, os poderes e deveres que lhe cabem, para exercê-los e cumpri-los em seu lugar, a fim de praticar ato jurídico como os de serventuários de ofício público -, ou de construir obre pública como de retificação de rio -, ou de prestar serviço público - como de fornecimento de energia elétrica" e "corresponde a ato administrativo constitutivo de direito a concessão pela qual o concedente delega ao concessionário poderes para utilizar ou explorar bem público, mas o atribui em qualidade inferior e quantidade menor dos que os tem, relativos, por exemplo, à exploração de jazidas e fontes minerais, à utilização de terrenos nos cemitérios como túmulos de famílias, à instalação de indústrias de pesca às margens do rio $^{204}$.

Compactua desse entendimento MARIA SYLVIA ZANELLO DI PIETRO ${ }^{205}$, para quem as concessões de serviço público e de obra pública, as patrocinadas e as administrativas, são exemplos de concessão translativa, ao passo que as concessões de uso de bem público são exemplo de concessão constitutiva.

No nosso entendimento, o contrato de concessão de petróleo configura uma modalidade de concessão de uso de exploração de bem público (concessão constitutiva),

XII - as penalidades aplicáveis na hipótese de descumprimento pelo concessionário das obrigações contratuais.

Parágrafo único. As condições contratuais para prorrogação do prazo de exploração, referidas no inciso II deste artigo, serão estabelecidas de modo a assegurar a devolução de um percentual do bloco, a critério da ANP, e o aumento do valor do pagamento pela ocupação da área, conforme disposto no parágrafo único do art. 51."

${ }^{204}$ MELLO, Oswaldo Aranha Bandeira. Princípios gerais do Direito Administrativo. $3^{\text {a }}$ ed. São Paulo: Malheiros, 2007. p. 557.

${ }^{205}$ PIETRO, Maria Sylvia Zanella. Uso privativo de bem público por particular, p. 109. 
que não se confunde com a concessão de serviço público ${ }^{206}$, embora ambas as modalidades sejam espécie do gênero concessão.

De fato, nos termos do artigo 177, inciso I, da Carta Maior, a União detém o monopólio da "pesquisa e a lavra das jazidas de petróleo e gás natural e outros hidrocarbonetos fluidos". A pesquisa e lavra são sinônimos de exploração e produção, de acordo com o artigo $6^{\circ}$, incisos XV e XVI, da Lei $\mathrm{n}^{\circ} 9.478 / 97^{207}$.

Noutras palavras, nos termos da Constituição Federal, a União detém o monopólio das atividades de exploração e produção do petróleo e gás natural. $\mathrm{O}$ artigo 21 da Lei ${ }^{\circ}$ 9.478/97 208 ressalta ainda que esse direito, que pode ser exercido em todo o território nacional, é de titularidade desse ente federativo.

Portanto, por meio do contrato de concessão de exploração do petróleo, a União confere ao concessionário apenas o direito de exploração e produção do petróleo e gás natural, como observa GILBERTO BERCOVICI:

\begin{abstract}
A autorização constitucional da apropriação pelo concessionário do produto da lavra diz respeito aos bens móveis extraídos, que não afeta a propriedade da União sobre os bens imóveis não extraídos. Por esse motivo, a concessão não é de direito real de uso, porque ela não outorga, além do direito de extrair e de se apropriar do que e quando se extraia, o direito do concessionário de se apropriar dos minerais do subsolo, antes de serem extraídos. Ela concede um direito de propriedade futura, uma espécie de direito de crédito, sobre um bem móvel quando extraído. A concessão mineral é um ato administrativo mediante o qual a União, sem transmitir o domínio ou um direito real sobe o subsolo, outorga ao titular da concessão o direito de explorar o subsolo, com os direitos conexos para que possa atuar, inclusive, com proteção frente a terceiros. Em decorrência disso, a natureza jurídica do contrato de concessão de exploração de petróleo, assim como o contrato de concessão de lavra mineral, é a de um contrato de concessão de uso de exploração de bens públicos indisponíveis ${ }^{209}$.
\end{abstract}

Compactua do mesmo entendimento ALEXANDRE SANTOS DE ARAGÃO ${ }^{210}$, para quem o objeto do contrato de concessão do petróleo não é o bem, a coisa, mas sim o

\footnotetext{
${ }^{206}$ Com efeito, na concessão de serviço público o Estado delega ao concessionário a execução de um serviço público ou obra pública que seriam de sua atribuição, ou seja, uma parcela de poderes, direitos e vantagens preexistentes do Poder concedente se descoloca para o concessionário. Já na concessão de uso privativo, o concessionário se utiliza de parcela do bem púbico, mas o direito dele sobre o bem é de natureza diversa daquele que o concedente exerce sobre o mesmo bem. Nessa modalidade, os direitos ou poderes conferidos ao concessionário derivam do ato de concessão (Ibid., p., 112).

207 "XV - Pesquisa ou Exploração: conjunto de operações ou atividades destinadas a avaliar áreas, objetivando a descoberta e a identificação de jazidas de petróleo ou gás natural;

XVI - Lavra ou Produção: conjunto de operações coordenadas de extração de petróleo ou gás natural de uma jazida e de preparo para sua movimentação."

${ }_{208}$ "Art. 21 Todos os direitos de exploração e produção de petróleo e gás natural em território nacional, nele compreendidos a parte terrestre, o mar territorial, a plataforma continental e a zona econômica exclusiva pertencem à União, cabendo sua administração à ANP."

${ }^{209}$ BERCOVICI, Gilberto. Direito Econômico do Petróleo e dos Recursos Minerais, p. 290.

${ }^{210}$ ARAGÃO, Alexandre Santos. O contrato de concessão de exploração de petróleo e gás.
} 
comportamento desempenhado pelo concessionário (direito de exercer a atividade econômica de pesquisa e lavra das jazidas de petróleo).

Da mesma forma, MARIA D’ASSUNÇÃO DA COSTA assevera que "o que se outorga aos particulares são apenas os direitos de exploração e produção - e nunca o próprio bem, que pertence à União, não passível de alienação" ${ }^{211}$.

Logo, o petróleo em si não é objeto do contrato de concessão. O concessionário não pactua com a União a "transferência" da sua propriedade, mas apenas o direito de explorar e produzir esse recurso mineral, que poderá resultar na sua descoberta.

Ante o exposto, temos para nós que a exploração de petróleo realizada por meio do contrato de concessão não se traduz em uma operação mercantil, porquanto essa modalidade contratual (i) está submetida ao regime de direito público e não privado e (ii) tem por objeto uma obrigação de fazer (explorar e produzir o petróleo e o gás natural) e não uma obrigação de dar uma mercadoria (não se trata de uma compra e venda, mas de um contrato de risco).

Em síntese, podemos concluir, até o momento, que a extração do petróleo não pode ser considerada como operação, tal como prescreveu o Constituinte, na medida em que não representa um ato jurídico mercantil. Não há que se falar também em circulação, pois a extração representa apenas o momento em que esse produto da natureza é retirado em seu estado bruto, tampouco em mercadoria, porquanto esse recurso mineral é um bem público de uso especial, por isso inalienável.

Portanto, os enunciados-enunciados veiculados pela Lei $\mathrm{n}^{\circ} 4.117 / 03$ foram produzidos pela autoridade competente (Assembleia Legislativa do Estado do Rio de Janeiro) em desconformidade com a regra de competência para a instituição do ICMS mercantil, na medida em que o legislador infraconstitucional não respeitou a materialidade constitucional desse imposto, ou seja, os "enunciados de autorização", segundo a acepção adotada por TÁCIO LACERDA GAMA.

Se não existe operação mercantil, cabe analisar, então, de que forma o concessionário se torna proprietário do petróleo extraído, como prescreve o artigo 26 da Lei ${ }^{\circ}$ 9.478/97, declarado constitucional pelo Supremo Tribunal Federal.

\footnotetext{
${ }^{211}$ COSTA, Maria D’Assunção. Comentários à Lei do Petróleo, p. 180.
} 


\subsubsection{Da conferência do petróleo ao concessionário após a sua extração}

Deve-se advertir, inicialmente, que a constitucionalidade do artigo 26 da Lei $n^{\circ}$ 9.478/97 foi analisada sob o enfoque exclusivo dos conceitos de monopólio, que foi relativizado pela Emenda Constitucional n ${ }^{\circ}$ 9/95, e de propriedade. Não se debateu, naquela ocasião, qual a natureza da "transferência" da propriedade do petróleo da União ao concessionário no momento da sua extração, como será abordado neste momento.

Deveras, a propriedade que a União exerce sobre o petróleo localizado no subsolo não se confunde com a propriedade clássica, regida pelo direito privado. Como tivemos a oportunidade de verificar, o petróleo, enquanto bem público de uso especial, está submetido ao regime da dominialidade pública.

Mesmo que se fosse possível analisar a relação instaurada entre a União e o petróleo localizado no subsolo sob a perspectiva do Direito Civil, as conclusões obtidas até o momento quanto à impossibilidade de transferência da propriedade do petróleo não se alterariam.

Isso porque, se não é possível aferir, até o momento da pesquisa, se existe o petróleo, em que quantidade e em que volume, como é possível falar efetivamente em propriedade?

Com efeito, a propriedade pressupõe a existência da posse sobre um bem. Nos dizeres de WASHINGTON DE BARROS MONTEIRO ${ }^{212}$, a posse é o exercício de fato dos poderes constitutivos do domínio, ou propriedade, ou de alguns deles somente. Segundo o autor, a posse constitui o sinal exterior da propriedade. Esse entendimento está em conformidade com o disposto no artigo 1196 do Código Civil ${ }^{213}$.

Ora, se o petróleo só se torna um produto individualizado após a sua extração, isso significa que a União, até esse momento, não pode se utilizar dessa coisa, tampouco dela dispor livremente.

Vale dizer, se a União não pode usar, gozar e dispor da coisa corpórea (esse último compreendido como o poder de usar da coisa, de aliená-la, de gravá-la de ônus e de submetê-la ao serviço de outrem ${ }^{214}$ ), conclui-se que o ente federativo não possui a posse do petróleo localizado no subsolo e, por consequência, a propriedade desse bem segundo a

\footnotetext{
${ }^{212}$ MONTEIRO, Washington de Barros. Curso de Direito Civil, Direito das Coisas. $40^{\mathrm{a}}$ ed. São Paulo: Saraiva, 2010. p. 31.

213 “Artigo 1196. Considera-se possuidor todo aquele que tem de fato o exercício, pleno ou não, de algum dos poderes inerentes à propriedade.

${ }^{214}$ MONTEIRO, Washington de Barros. Curso de Direito Civil, Direito das Coisas, p. 103.
} 
concepção do direito privado, o que impede, por imposição lógica, a sua transferência para outrem.

Portanto, a conferência do petróleo extraído ao concessionário, a que alude o artigo 26 da Lei $n^{\circ}$ 9.478/97, não pode ser interpretada como "transferência" de propriedade, mas aquisição originária de propriedade pelo concessionário, que é garantida pela própria Constituição Federal na parte final do artigo 176, caput.

De acordo com as lições de SILVIO VENOSA ${ }^{215}$, a aquisição da propriedade é originária quando desvinculada de qualquer relação com titular anterior. Nela não existe relação jurídica de transmissão. Inexiste ou não há relevância jurídica na figura do antecessor. A título exemplificativo, o autor cita o usucapião como forma originária de aquisição. De acordo com o civilista,

[...] o bem usucapido pode ter pertencido a outrem, mas o usucapiente dele não recebe a coisa. Seu direito de aquisição não decorre do antigo proprietário. $\mathrm{Na}$ aquisição originária, o único elemento para que ela concorre é o próprio fato ou ato jurídico que lhe dá nascimento ${ }^{216}$.

Já a aquisição derivada de propriedade ocorre quando há uma relação jurídica com o antecessor. Existe transmissão de propriedade de um sujeito a outro. A regra fundamental nessa modalidade é a de que ninguém pode transferir mais direitos do que tem: nemo plus Iuri ad alium transfere potest, quam ipse haberet ${ }^{217}$.

Vale dizer, o concessionário não se torna proprietário do petróleo extraído em razão de um negócio jurídico praticado com a União que lhe transfere a propriedade (aquisição derivada de propriedade, passível de incidência do ICMS caso o bem transferido seja qualificado como mercadoria). Ao contrário, a apropriação do petróleo decorre dos próprios atos materiais realizados por ele (lavra e pesquisa), que permite a apreensão física desse recurso mineral.

Nota-se, assim, que a Constituição Federal prevê duas titularidades distintas: da União sobre os recursos minerais e jazidas (artigo 20, inciso IX, e artigo 176, caput), de um lado, e a do concessionário explorador sobre o produto do resultado da lavra - (artigo 176, caput, parte final), de outro.

No tocante especificamente ao petróleo, e em linha com o texto constitucional, o artigo $3^{\circ}$ da Lei n 9.478/97 assim prescreve: "Pertencem à União os depósitos de petróleo,

\footnotetext{
${ }^{215}$ VENOSA, Silvio de Salvo. Direitos reais. $9^{a}$ ed. São Paulo: Atlas, 2009. p. 181

216 Ibid., p. 181.

217 Ibid., p. 182.
} 
gás natural e outros hidrocarbonetos fluidos existentes no território nacional, nele compreendidos a parte terrestre, o mar territorial, a plataforma continental e a zona economia exclusiva."

Percebe-se, destarte, que a União detém a propriedade do depósito, ou seja, “configuração geológica armazenadora de petróleo ou gás" (artigo 60 inciso X, da Lei nº 9478/97), bem como da jazida, definida como “o reservatório ou depósito já identificado e possível de ser posto em produção" (artigo 6º inciso XI, da Lei n ${ }^{\circ}$ 9478/97). Já o produto mineral, resultado do produto da exploração da jazida, pertence a quem o produziu.

Assim, o petróleo, enquanto estiver localizado nos depósitos e jazidas, pertence à União. Uma vez extraído (produzido), pertence ao concessionário extrator por expressa determinação constitucional.

Nesse sentido, MARIA D’ASSUNÇÃO COSTA assevera: “[...] o regime jurídico do petróleo e do gás natural extraído, em decorrência da Constituição Federal, desta Lei e do Contrato de Concessão, passa a ser propriedade exclusiva do concessionário para todos os efeitos legais" 218 .

Ante as considerações feitas anteriormente, concluímos que, além da impossibilidade de enquadrar o petróleo como mercadoria no momento da sua extração, mas mero produto, o que, por si só, inviabiliza a sua circulação jurídica, não há também, nessa ocasião, transferência de titularidade desse bem, mas apenas a sua "conferência" (leia-se: aquisição originária da sua propriedade depois de extraído), nos termos do artigo 26 da Lei $n^{\circ}$ 9.478/97 e artigo 176, caput da Carta Maior, o que nos permite concluir que a extração do petróleo não se configura como uma operação relativa à circulação de mercadoria (critério material constitucional do ICMS mercantil).

\subsection{Critério temporal: passagem do petróleo pelos postos de medição de produção}

O legislador ordinário estadual estabeleceu como critério temporal do ICMS a passagem do petróleo pelos pontos de medição de produção, nos termos do artigo $3^{\circ}$ da Lei $n^{\circ} 4.117 / 03$.

Passamos a verificar se esse momento está em conformidade com o critério temporal desse imposto, qual seja: a saída da mercadoria do estabelecimento do contribuinte, tal como prescreve o artigo 12, inciso I, da Lei Complementar $n^{\circ} 87 / 96$.

${ }^{218}$ COSTA, Maria D’Assunção. Comentários à Lei do Petróleo, p. 191. 
Com efeito, o artigo $3^{\circ}, \S 10$, da Lei $n^{\circ} 4.117 / 03$ define os pontos de medição da produção como:

[...] aqueles pontos definidos no plano de desenvolvimento de cada campo nos termos da legislação em vigor, onde se realiza a medição volumétrica do petróleo produzido nesse campo, expressa nas unidades métricas de volume adotadas pela Agência Nacional de Petróleo - ANP e referida à condição padrão de medição, e onde o concessionário, a cujas expensas ocorrer a extração, assume a propriedade do respectivo volume de produção fiscalizada, sujeitando-se ao pagamento dos tributos incidentes e das participações legais e contratuais correspondentes.

Como já demonstrado, a passagem do petróleo pelos pontos de medição de produção reflete apenas o instante em que o petróleo deixa a jazida, de propriedade da União, e se transforma em produto de propriedade do concessionário, por determinação constitucional.

Noutras palavras, esse momento exterioriza apenas o evento da produção do petróleo, que não configura, como vimos, uma operação relativa à circulação de mercadorias que dá ensejo à incidência do ICMS.

Nota-se, ainda, que o legislador estadual, ao eleger o critério temporal do ICMS como a passagem do petróleo pelo ponto de medição de produção, buscou equiparar esse imposto com os denominados royalties e a participação especial, cuja referência a esse momento é indicativa da passagem do domínio público ao privado ${ }^{219}$.

Portanto, a passagem do petróleo pelos pontos de medição de produção não pode ser considerada o critério temporal da hipótese de incidência desse imposto ${ }^{220}$, até porque nem sequer está previsto no artigo $2^{\circ}$ da Lei Complementar $n^{\circ} 87 / 96$, enunciado

\footnotetext{
${ }^{219}$ Nos termos do artigo $3^{\circ}$, inciso IV, do Decreto $\mathrm{n}^{\circ} 2.705 / 98$, que define critérios para cálculo e cobrança das participações governamentais de que trata a Lei $n^{\circ}$ 9.478/97, aplicáveis às atividades de exploração, desenvolvimento e produção de petróleo e gás natural, os pontos de medição de produção são definidos como "pontos a serem obrigatoriamente definidos no plano de desenvolvimento de cada campo, propostos pelo concessionário e aprovados pela ANP, nos termos do contrato de concessão, onde será realizada a medição volumétrica do petróleo ou do gás natural produzido nesse campo, expressa nas unidades métricas de volume adotadas pela ANP e referida à condição padrão de medição, e onde o concessionário assumirá a propriedade do respectivo volume de produção fiscalizada, sujeitando-se ao pagamento dos tributos incidentes e das participações legais e contratuais correspondentes".

${ }^{220}$ Nesse sentido, ANTÔNIO CORREA MEYER e RAQUEL NOVAIS se posicionaram: "Dessa forma, em conformidade com o exposto até o momento, entende-se ser sustentável que o ICMS não pode ser exigido do extrator do petróleo no momento de sua extração, pois esse momento apenas indica o ponto a partir do qual o petróleo passa a existir como um produto, sendo sua propriedade diretamente conferida ao seu produtor. Portanto, no momento da extração do petróleo não há transferência de propriedade, razão por si só suficiente para tornar ilegítima a cobrança do ICMS prevista na Lei Noel (MEYER, Antônio Correa Meyer; NOVAIS, Raquel. Análise da Validade da Cobrança de ICMS sobre a Extração de Petróleo no Estado do Rio de Janeiro: Lei Noel. Revista de Direito Tributário n 93. São Paulo: Malheiros, p. 84).
} 
complementar que delimita a criação do ICMS, nos termos do artigo 155 , §2º, XII, da Constituição Federal, como bem observou TÁCIO LACERDA GAMA ${ }^{221}$.

\subsection{Critério espacial do ICMS e as jazidas de petróleo}

Como tivemos a oportunidade de verificar, o legislador complementar elegeu o "estabelecimento" como critério espacial do ICMS nas operações mercantis realizadas com mercadorias, o qual foi definido pelo artigo $11, \S 3^{\circ}$, da Lei Complementar $n^{\circ} 87 / 96$, como “[...] o local, privado ou público, edificado ou não, próprio ou de terceiros, onde pessoas físicas ou jurídicas exerçam suas atividades em caráter temporário ou permanente, bem como onde se encontram armazenadas mercadorias".

A Lei $n^{\circ} 4.117 / 03$ prescreve, por sua vez, que "para efeito de cobrança do imposto e definição do estabelecimento responsável, considera-se local da operação aquele onde o petróleo tenha sido extraído"222.

Como se sabe, o petróleo é extraído da jazida, definida como "o reservatório ou depósito já identificado e possível de ser posto em produção" (artigo 6º inciso XI, da Lei $n^{\circ}$ 9.478/97). Esse foi, portanto, o critério espacial eleito pelo legislador ordinário estadual.

No nosso entendimento, não há possibilidade de equiparar o conceito de jazida ao conceito de estabelecimento dado pelo legislador complementar.

Primeiro porque a União, pessoa jurídica de direito público interno, não é contribuinte do ICMS, pois esse ente federativo não se confunde, por óbvio, com comerciante, industrial ou produtor, como será demonstrado oportunamente. Assim, a jazida não pode ser compreendida como local onde a União exerce suas atividades mercantis.

Segundo porque o petróleo encontrado na jazida não se caracteriza como mercadoria, pois não se destina à mercancia. Como tivemos oportunidade de analisar, trata-se de um bem público de uso especial, insuscetível de alienação. Mesmo se

221 TÁCIO LACERDA GAMA explica que os enunciados complementares "são as proposições, inseridas por lei complementar, que, por expressa disposição constitucional, devem ser consideradas na formação da competência tributária legislativa" (Competência tributária, fundamentos para uma teoria da nulidade, p. 258).

${ }_{222}{ }^{2}$ Art. $6^{\circ}$ - O art. 30 da Lei $n^{\circ}$ 2.657, de 26 de dezembro de 1996, passa a vigorar com a seguinte redação, acrescido da alínea ' 'l', no inciso I:

'Art. 30 - Para efeito de cobrança do imposto e definição do estabelecimento responsável, considera-se:

I - local da operação:

1 - aquele de onde o petróleo tenha sido extraído'." 
descoberto, esse recurso mineral, quando lavrado, não pode ser qualificado como mercadoria, mas mero produto que ainda não foi posto em circulação.

Nota-se, portanto, que o legislador ordinário estadual não observou o artigo $11, \S 3^{\circ}$, da Lei Complementar $n^{\circ}$ 87/96, ao eleger o local onde ocorre a exploração do petróleo como o critério espacial do ICMS.

Tal conclusão não se altera se as jazidas de petróleo estiverem localizadas no mar territorial, na plataforma continental ou na zona econômica exclusiva. Independentemente dessa constatação, iremos analisar se os Estados da federação detêm competência para exigir o ICMS quando a extração do petróleo ocorrer nessas áreas marítimas.

\subsubsection{Vigência territorial do ICMS e extraterritorialidade}

Vigência é a aptidão que certas normas jurídicas apresentam de propagar os seus efeitos, tão logo se opere a sua incidência. Assim, ter vigência é ter força para irradiar efeitos jurídicos. Não se confunde com validade, que é a relação de pertinencialidade da norma com o sistema do direito positivo, como já demonstramos, tampouco com eficácia, que está relacionada com a produção dos efeitos normativos, que pode ser técnica, jurídica e $\operatorname{social}^{223}$.

As proposições jurídicas têm sua vigência propagada no tempo e no espaço. Com relação a essa última, as normas vigoram nos limites territoriais do ente federativo que as instituiu. Assim, as normas criadas pelos Municípios estão aptas a produzir efeitos dentro dos limites municipais. Da mesma forma as normas produzidas pelos Estados e União, que podem irradiar efeitos dentro dos limites territoriais estatais e brasileiro. Vige, portanto, no direito pátrio, o princípio da territorialidade, que desempenha, em nosso sistema constitucional tributário, relevante papel, conforme explica PAULO DE BARROS CARVALHO:

Sem territorialidade que permite a desconcentração das fontes produtoras das
normas não há autonomia municipal (art. 18, da CF); não há federação (art. $1^{\circ}$,
da $C F$ ), não resta unidade, nem soberania para a República Federativa do Brasil
(...).
O princípio (ou valor) da territorialidade, sendo fundamental, está pressuposto,
não se manifestando de maneira expressa, a não ser topicamente, na fraseologia
constitucional brasileira. Constitui, porém, o perfil do Estado federal, como

${ }^{223}$ Eficácia jurídica é a propriedade do fato jurídico de provocar os efeitos que lhe são próprios. A eficácia técnica é a qualidade que a norma ostenta de descrever fatos que, uma vez ocorridos, tenham aptidão de irradiar efeitos. A eficácia social eh a produção concreta dos resultados na ordem social. 
decorrência imediata das diretrizes básicas conformadoras do sistema. O Poder vinculante de uma lei ensejará efeitos jurídicos dentro dos limites geográficos da pessoa que o editou. A lei federal e a nacional, por todo o território brasileiro; as estaduais, internamente a suas fronteiras regionais; e as municipais, no interior dos limites de seus espaços geográficos; assim acontecendo com o Distrito Federal $^{224}$.

Portanto, a União, os Estados e os Municípios, ao exercitarem a competência tributária que lhe foi atribuída pela Constituição Federal, devem respeitar os limites dos respectivos territórios, como bem observa AIRES FERNANDINO BARRETO:

Ante as balizas postas pelos princípios e normas constitucionais, o âmbito de eficácia das leis municipais tem seus limites coincidentes com os do seu território, assim como o das leis estaduais, cuja amplitude esgota-se nos seus limites territoriais. As leis de um Município a ninguém obrigam fora do seu território, eis que elas só têm eficácia no interior dele. De outra parte, como já vimos de observar, os territórios municipais, por sua vez, têm seus limites fixados por lei estadual, observada a Constituição. Igualmente, as leis de um Estado-membro: seu campo de ação ou eficácia circunscreve-se pelos mesmos limites do seu território, não atuam fora dele. As leis do Mato Grosso não têm efeitos jurídicos em São Paulo, ou em Minas Gerais, ou em qualquer outro Estado-membro; só vão até as suas divisas com este ou com outros Estadosmembros; não as ultrapassam. O legislador municipal não pode, jamais, editar, validamente, lei tributária, prevendo a produção de seus efeitos sobre fatos ou relações efetivadas fora dos lindes do território do Município. Se assim o fizer, criará lei inválida por não encontrar fundamento na Constituição Federal ${ }^{225}$.

Da mesma forma, LUCAS GALVÃO DE BRITTO, em brilhante estudo sobre o lugar do tributo, assevera:

O território e, mais precisamente, o respeito aos territórios deve ocorrer na demarcação do domínio de vigência das normas: não pode um ente prescrever que a legislação tributária por ele editada tenha vigor e recorte elementos estranhos aos limites de seu território. Com isso, limita-se também a escolha que o legislador pode fazer para determinar o lugar do tributo: ainda que o conjunto de movimentos espalhe-se por vários municípios, deve-se atribuir-lhe, segundo o critério espacial, apenas um lugar que, se estiver quadrado dentro do seu território, poderá servir de fundamento à incidência do tributo ${ }^{226}$.

De forma excepcional, a vigência de certas normas jurídicas pode extrapolar o limite territorial do ente federativo que a produziu, surgindo o efeito da extraterritorialidade da

\footnotetext{
${ }^{224}$ CARVALHO, Paulo de Barros. O princípio da territorialidade no Direito Tributário. Revista de Direito Tributário $\mathrm{n}^{\circ} 76$.

${ }^{225}$ BARRETO, AIRES Fernandino. ISS - Não incidência sobre atividades desenvolvidas em águas marítimas Revista Dialética de Direito Tributário. São Paulo, n. 200. 2012.

${ }^{226}$ BRITTO, Lucas Galvão. O lugar e o tributo. Estudo sobre o critério espacial da regra-matriz de incidência tributária no exercício da competência tributária para instituir e arrecadar tributos, p. 156.
} 
lei, que está prevista no artigo 102 do $\mathrm{CTN}^{227}$, e é permitida apenas quando firmados os Convênios entre os entes políticos ${ }^{228}$.

No que concerne ao ICMS, a operação mercantil que promove a circulação de mercadoria (materialidade desse tributo) deve, necessariamente, ocorrer nos limites físicos do território do Estado instituidor do tributo, como bem observou CLÉBER GIARDINO ao discorrer sobre a territorialidade do antigo ICM:

Pode-se, portanto, assentar - nestas considerações iniciais - o princípio geral de que, no campo do ICM, a "operação" em que consiste a materialidade da hipótese de incidência desse tributo (para idoneamente provocar o devido efeito do nascimento de obrigações de ICM) deve "materialmente" ocorrer nos limites físicos do território do Estado instituidor do tributo. Descabem, portanto, em matéria de ICM, as "prorrogações territoriais" (no sentido referido ao início) consentidas e toleradas em outras matérias. Quanto ao ICM, é conclusão necessária que só a operação real e concretamente ocorrida no território de cada Estado - portanto dentro do âmbito geográfico, espacial ou territorial de abrangência ou validade dessa legislação - pode, habilmente, realizar o "fato imponível". "Operação relativa à circulação de mercadoria" acontecida fora do território de um Estado não poderá - sob pena de frustação de fundamentos constitucionais os mais elementares - ficar sujeita à disciplina tributária desse mesmo Estado ${ }^{229}$.

Destarte, falece competência a qualquer Estado da federação tributar, por meio do ICMS, operações mercantis realizadas fora dos seus limites territoriais. Fora dessas áreas, as leis estaduais que instituíram esse imposto não possuem vigência, ou seja, não são aptas a produzir os seus efeitos.

227 “Art. 102 A legislação tributária dos Estados, do Distrito Federal e dos Municípios vigora, no país, fora dos respectivos territórios, nos limites em que lhe reconheçam a extraterritorialidade os convênios de que participem, ou do que disponham esta ou outras leis de normas gerais expedidas pela União."

${ }^{228}$ Nesse sentido PAULO DE BARROS CARVALHO afirma: "Recolhido o fato de ser o Brasil, juridicamente, uma federação, e o de haver Municípios dotados de autonomia, a vigência das normas tributárias ganha especial e relevante importância. Vê-se, na disciplina do Texto Constitucional, a preocupação sempre presente de evitar que a atividade legislativa de cada uma das pessoas políticas interfira nas demais, realizando a harmonia que o constituinte concebeu. É a razão de ter-se firmado a diretriz segundo a qual legislação produzida pelo ente político vigora no seu território e, fora dele, tão somente nos estritos limites em que lhe reconheçam extraterritorialidade os convênios de que participem. Nessa linha de raciocínio, as normas jurídicas editadas por um Estado são vigentes para colher os fatos que aconteçam dentro de seus limites geográficos, o mesmo ocorrendo com os Municípios e com a própria União. Todavia, desde que celebrem convênios entre os Estados e entre os Municípios, alguns princípios de extraterritorialidade podem ser eleitos e, nessa dimensão, as normas de um serão vigentes no território do outro. Passa-se o mesmo com a União, quer na sua qualidade de pessoa de direito constitucional interno, quer como pessoa no direito das gentes. Participando no concerto das nações, assina tratados e convenções internacionais que têm o condão de imprimir vigência às suas normas, mesmo em território estrangeiro (Curso de Direito Tributário, p. 120).

${ }^{229}$ GIARDINO, Cleber. Territorialidade e ICM. Revista de Direito Mercantil, Industrial, Econômico e Financeiro. São Paulo, v.43, jul./set. 1981 . p.19-28. 
Estabelecidas essas premissas, passamos a verificar se os Estados detêm competência para exigir o ICMS quando a extração do petróleo ocorre em águas marítimas (offshore).

Essa análise se mostra relevante, sobretudo porque as maiores reservas de petróleo estão, atualmente, na plataforma continental, em águas profundas e ultraprofundas, enquanto a produção terrestre está concentrada, principalmente, nas regiões Norte e Nordeste e, em menor escala, no Sudeste, na área do Espírito Santo ${ }^{230}$.

\subsubsection{Competência exclusiva da União para dispor sobre as águas marítimas}

A Constituição Federal contempla, no seu artigo 20, o rol de bens da União, dentre os quais se destacam os recursos naturais da plataforma continental e da zona econômica exclusiva (inciso V) e o mar territorial (inciso VI).

A leitura do enunciado constitucional em questão já desperta no intérprete uma primeira dúvida, qual seja, o sentido do termo União empregado pelo legislador constitucional, que pode ser tanto a pessoa jurídica de direito público interno quanto a República Federativa do Brasil.

Deveras, a União, no plano internacional, representa a totalidade do Estado brasileiro. É o único titular da soberania, considerada poder supremo consistente na capacidade de autodeterminação.

Nesse diapasão, ROQUE ANTÔNIO CARRAZA esclarece que "a soberania, como qualidade jurídica do imperium, é apanágio exclusivo do Estado. Se ele não tivesse um efetivo predomínio sobre as pessoas que o compõem, deixaria de ser Estado. Daí concluirmos que a soberania é inerente à própria natureza do Estado." 231

Já no plano interno, a União, assim como os demais entes federativos (Estados, Distrito Federal e Municípios), são titulares da autonomia, compreendida como governo próprio dentro do círculo de competências traçadas pela Constituição Federal.

Verifica-se, assim, que soberania e autonomia são conceitos distintos. A soberania se refere ao caráter supremo de um poder, que não admite qualquer outro acima ou em concorrência com ele. Por sua vez, a autonomia pressupõe a tríplice capacidade de auto-

\footnotetext{
$230<$ <ttp://www.Petrobras.com.br/pt/quem-somos/perfil/atividades/exploracao-producao-petroleo-gas/>. Acesso em 10 Out 2012.

${ }^{231}$ CARRAZA, Roque Antônio. Princípio Federativo e Tributação. Revista Justitia, n 47, jul.-set. 1998. p. 164.
} 
organização, autogoverno e autoadministração. Nesse sentido são as palavras de CELSO RIBEIRO BASTOS:

\begin{abstract}
Soberania é o atributo que se confere ao poder do Estado em virtude de ser ele juridicamente ilimitado. Um Estado não deve obediência jurídica a nenhum outro Estado. Isso o coloca, pois, numa posição de coordenação com os demais integrantes da cena internacional e de superioridade dentro do seu próprio território, daí ser possível dizer da soberania que é um poder que não encontra nenhum outro acima dela na arena internacional e nenhum outro que lhe seja nem mesmo em igual nível na ordem interna.

A autonomia, por outro lado, é a margem de discrição de que uma pessoa goza para decidir sobre os seus negócios, mas sempre delimitada essa margem pelo próprio direito. Daí porque se falar que os Estados-membros são autônomos, ou que os municípios são autônomos: ambos atuam dentro de um quadro ou de uma moldura jurídica definida pela Constituição Federal. Autonomia, pois, não é uma amplitude incondicionada ou ilimitada de atuação na ordem jurídica, mas, tãosomente, a disponibilidade sobre certas matérias, respeitados, sempre, princípios fixados na Constituição ${ }^{232}$.
\end{abstract}

Feita essa digressão, passamos a analisar a que regime jurídico estão submetidos o mar territorial, a plataforma continental e a zona econômica exclusiva, bem como se essas áreas marítimas integram o território dos Estados.

\title{
4.4.2.1. Mar territorial
}

Os conceitos de plataforma continental, zona econômica exclusiva e mar territorial foram estabelecidos pela Convenção das Nações Unidas sobre os Direitos do Mar (CNDUM), realizada em Montego Bay (Jamaica) em 1982, a qual foi ratificada pelo Brasil em 22/12/88 e posteriormente reiterada pela Lei $n^{\circ} 8.617 / 1993$, a qual dispõe de forma mais detalhada sobre esses espaços no Direito Brasileiro.

Conforme a referida Convenção, o mar territorial, que está compreendido entre os bens da União, como estabelece o artigo 20, inciso VI, da Carta Maior, é a faixa de mar que se estende desde a linha de base até uma distância de 12 milhas marítimas ${ }^{233}$ da costa sobre a qual o Estado exerce a sua soberania.

\footnotetext{
${ }^{232}$ BASTOS, Celso Ribeiro. Curso de Direito Constitucional. São Paulo: Celso Bastos Editora, 2002, p. $473 / 474$

${ }^{233}$ No século XVIII, vários Estados adotaram, por razões militares, a largura do mar territorial de três milhas, pois essa extensão correspondia à distância aproximada do alcance de um tiro de canhão localizado na costa do Estado.
} 
De acordo com o artigo $2^{\circ}$ da Convenção em apreço, "a soberania do Estado costeiro estende-se também ao espaço aéreo sobrejacente ao mar territorial, bem como ao leito e ao subsolo desse mar".

Frise-se, ainda, que a própria Lei Federal n $8.617 / 93$ esclareceu que o Brasil exerce soberania sobre o mar territorial (artigo $2^{\circ 234}$ ) e não apenas direito de propriedade.

Em que pese a soberania estatal sobre o mar territorial, a Convenção assegura o direito de passagem inocente ${ }^{235}$, pelo mar territorial aos navios de todos os Estados. Como consequência, o trânsito de navios pelo mar territorial de um Estado independe de autorização prévia do Estado que exerce a soberania sobre essa faixa do mar.

Nota-se, portanto, que a União, como citado no artigo 20, VI, da Carta Maior, não consiste na pessoa jurídica de direito público interno, mas sim na própria República Federativa do Brasil, pessoa jurídica de direito público internacional, que detém soberania sobre o mar territorial.

Nesse sentido, são esclarecedoras as lições de IVES GANDRA DA SILVA MARTINS:

Critica-se a outorga à União, uma das pessoas da federação, da competência absoluta para manter as relações com Estados estrangeiros. É o Estado federativo que mantém as relações, utilizando-se do aparelho administrativo da União, visto que tais relações afetam a federação, por inteiro, e não apenas a União ${ }^{236}$.

Diante da existência dessa soberania, as matérias concernentes ao mar territorial são de competência exclusiva da União, não havendo espaço para que os Estados-membros da federação, que possuem apenas autonomia, produzam normas que tenham eficácia sobre fatos ocorridos nessas áreas, sobretudo em matéria tributária.

Tal conclusão pode ser extraída do próprio texto constitucional, o qual estabelece a competência privativa da União para legislar sobre o direito marítimo (artigo 22, inciso I), bem como a competência comum da União, Estados-membros e Municípios (artigo $23^{237}$ ),

\footnotetext{
234 “Art. $2^{\circ}$ A soberania do Brasil estende-se ao mar territorial, ao espaço aéreo sobrejacente, bem como ao seu leito e subsolo."

${ }^{235}$ De acordo com a Convenção, passagem inocente tem com requisito essencial a natureza rápida e sem interrupções, salvo as decorrentes de incidentes normais da navegação e as que se derem por motivo de força maior ou dificuldade grave, assim como as feitas por motivo de auxílio a pessoas, navios ou aeronaves em perigo ou dificuldades graves.

${ }^{236}$ MARTINS, Ives Gandra. Comentários à Constituição do Brasil. São Paulo: Saraiva, 1992. 3 v. p. 110.

237 “Art. 23. É competência comum da União, dos Estados, do Distrito Federal e dos Municípios:

I - zelar pela guarda da Constituição, das leis e das instituições democráticas e conservar o patrimônio público;

II - cuidar da saúde e assistência pública, da proteção e garantia das pessoas portadoras de deficiência;
} 
dentre as quais não se inclui o mar territorial (tampouco a plataforma continental e a zona econômica exclusiva, que sequer integram o território brasileiro, como será demonstrado adiante). Nesse sentido AIRES FERNANDINO BARRETO ${ }^{238}$ se posicionou ao discorrer sobre a impossibilidade de cobrança do ISS sobre águas marítimas.

Esse mesmo entendimento foi invocado na Ação Declaratória de Inconstitucionalidade $\mathrm{n}^{\mathrm{o}} 2080^{239}$ proposta pela Confederação Nacional do Transporte (CNT), em que se postula a declaração de inconstitucionalidade do artigo 194, §5º da Constituição do Estado do Rio de Janeiro ${ }^{240}$, o qual prevê a competência desse Estado e dos Municípios fluminenses sobre os respectivos territórios, inclusive as projeções marítimas da sua área continental (plataforma continental, mar territorial e zona econômica

III - proteger os documentos, as obras e outros bens de valor histórico, artístico e cultural, os monumentos, as paisagens naturais notáveis e os sítios arqueológicos;

IV - impedir a evasão, a destruição e a descaracterização de obras de arte e de outros bens de valor histórico, artístico ou cultural;

V - proporcionar os meios de acesso à cultura, à educação e à ciência;

VI - proteger o meio ambiente e combater a poluição em qualquer de suas formas;

VII - preservar as florestas, a fauna e a flora;

VIII - fomentar a produção agropecuária e organizar o abastecimento alimentar;

IX - promover programas de construção de moradias e a melhoria das condições habitacionais e de saneamento básico;

$\mathrm{X}$ - combater as causas da pobreza e os fatores de marginalização, promovendo a integração social dos setores desfavorecidos;

XI - registrar, acompanhar e fiscalizar as concessões de direitos de pesquisa e exploração de recursos hídricos e minerais em seus territórios;

XII - estabelecer e implantar política de educação para a segurança do trânsito.

238 "Não é despiciendo lembrar que as definições de áreas das águas marítimas constitutiva do mar territorial, da plataforma continental e da zona econômica exclusiva são estabelecidas por legislação federal. Assim, coerentemente com as normas da CF conformados do nosso Estado federal, é a União que tem jurisdição sobre as águas marítimas, em quaisquer dos seus aspectos (BARRETO, Aires Fernandino. ISS - Não Incidência sobre Atividades desenvolvidas em águas marítimas.).

${ }^{239}$ Conforme se extrai do relatório do acordão proferido na Medida Cautelar da ADIN no 2080, a discussão fática é a seguinte:

"1.1. Empresas de táxi aéreo vinculadas à autora transportam pessoas e cargas do continente para pontos situados no mar territorial ou sobre a plataforma continental e vice-versa, ou entre um ponto e outro do mar territorial. Um exemplo desse serviço de transporte aéreo é o contratado pela Petrobras e realizado por helicópteros que usualmente partem dos aeródromos de Macaé e Campos, no Estado do Rio de Janeiro, com destino à bacia de Campos, no mar territorial. Operações inversas, isto é, das plataformas de exploração de petróleo para algum ponto do continente, também são frequentes.

1.2. Esse serviço de transporte é aqui designado como "anômalo" para distingui-lo do transporte realizado entre Estados interestadual ou entre Municípios intermunicipal. Caracteriza-se esse transporte por começar ou terminar num ponto do mar territorial que não se situa no espaço territorial de qualquer dos Estados da federação, nem de qualquer dos Municípios brasileiros. A partir de tal peculiaridade, questiona a possibilidade de o Estado do Rio de Janeiro cobrar ICMS sobre esse tipo de transporte.

A partir de tal peculiaridade, aqui se questiona a possibilidade de o Estado do Rio de Janeiro cobrar ICMS sobre esse tipo de transporte".

240 “Artigo 194. Os Estados e os Municípios poderão instituir os seguintes tributos:

(...)

$\S 5^{\circ}$. A competência tributária do Estado e dos Municípios é exercida sobre a área dos respectivos territórios, incluindo nestes as projeções aérea e marítima de sua área continental, especialmente as correspondentes partes da plataforma continental, do mar territorial e da zona econômica exclusiva." 
exclusiva). Entretanto, o Ministro Gilmar Mendes indeferiu a Medida Cautelar pleiteada na referida ADIN, sob o argumento de que:

(i) O mar territorial, a plataforma continental e a zona econômica exclusiva são parcelas do território nacional e, portanto, integram o território dos Estados e dos Municípios; e

(ii) $\mathrm{O}$ critério a ser utilizado para a repartição dessas áreas marítimas entre os Estados e Municípios deve ser o mesmo que serviu para sua divisão entre o Brasil e os seus vizinhos, ou seja, integram eles o território dos Estados e do Município em frente a cujos litorais se encontrem.

Não há dúvida de que o mar territorial, e apenas ele, pertence ao território nacional e, por consequência, integra também o território dos Estados e dos Municípios, mas não há, contudo, qualquer norma nacional que especifique qual parcela do mar territorial cabe a cada Estado estabelecido na costa brasileira, o que seria indispensável para evitar os conflitos de competência entre os Estados-membros.

Nesse ponto, destaca-se a importância do sentido negativo do princípio da territorialidade para evitar conflitos territoriais entre os Estados, como bem asseverou LUCAS GALVÃO DE BRITTO:

\begin{abstract}
O princípio da territorialidade pode ser enunciado de forma positiva - porque permite ao sujeito competente o exercício de sua potestade normativa sob as bases geográficas que a legislação administrativa reconhece como seu território ou negativa - na medida em que restringe o exercício da conduta monogenética de outros entes nessa mesma fração espacialmente considerada.

Imediatamente, dada a forma de Estado Federado que assume a República do Brasil, deve-se explicar que o sentido negativo da territorialidade afirma-se somente no conflito entre Estados, Municípios ou destes com o Distrito Federal. Descabe, em nosso ordenamento tratar de conflitos territoriais entre Estado e Município, da União para com um Município ou entre essa e um Estado. Isso porque as bases territoriais sobre as quais assenta-se a União abrangem a dos Estados e, estes, por sua vez, compartilham a extensão geográfica de seu território com um bom número de Municípios. Dada essa condição, os conflitos que entre eles possam surgir não terão por fundamento o território, mas sim, as materialidades constitucionalmente outorgadas para cada $\mathrm{um}^{241}$.
\end{abstract}

Com efeito, o artigo 155, parágrafo $2^{\circ}$, inciso XII, “d”, da Carta Maior exige a edição de lei complementar para dispor sobre "o local das operações relativas à circulação de mercadorias" para fins de cobrança e definição do estabelecimento responsável.

Ocorre que a Lei Complementar $n^{\circ} 87 / 96$ nem sequer contemplou o mar territorial, a plataforma continental e a zona econômica exclusiva como um desses locais,

${ }^{241}$ BRITTO, Lucas Galvão. O lugar e o tributo. Estudo sobre o critério espacial da regra-matriz de incidência tributária no exercício da competência tributária para instituir e arrecadar tributos, p. 155. 
diversamente do que previa o artigo $27, \S 8^{\circ}$, do Convênio $66 / 88^{242}$, o qual estabelecia que tais áreas integravam o território do Estado e do Município que lhe é confrontante.

Além de não estabelecer o mar territorial como local onde ocorre a circulação de mercadorias, a Lei Complementar $n^{\circ}$ 87/96 não contém regras para operacionalizar a incidência desse imposto. Nesse sentido, são oportunos os esclarecimentos de MARCO AURÉLIO GRECO:

Realmente, seu artigo 11, I, “a”, estabelece que o local da operação é o do estabelecimento em que a mercadoria se encontre "no momento da ocorrência do fato gerador".

Ora, tratando-se, por hipótese, de venda de mercadorias estrangeiras a bordo de um navio, o fato gerador ocorrerá em loja ou restaurante.

Portanto, o "local" para fins de incidência do ICMS seria este (admitindo-se para fins de análise que loja possa ser considerada um estabelecimento autônomo). De imediato, nota-se a falta de regras necessárias a operacionalizar a incidência, pois não há nenhum preceito a prever que a loja ou o restaurante interno do navio seja, considerados estabelecimentos autônomos pela legislação do ICMS.

Além disso, os incisos I e II do artigo 12 da Lei Complementar $\mathrm{n}^{\circ}$ 87/96 preveem que o momento da ocorrência do fato gerador se dá no momento da saída da mercadoria do estabelecimento do contribuinte ou do fornecimento de alimentação, bebidas e outras mercadorias por qualquer estabelecimento.

Ora, não há "saída do estabelecimento", por faltar a regra mencionada. "Fornecimento, em tese, pode existir, mas também a disciplina legal é insuficiente, pois não basta alegar que o fato gerador ocorreu."

Lembre-se que as operações e prestações podem ocorrer, como exemplificado, a bordo de um navio em movimento. Portanto, no momento do "fornecimento" não basta dizer que ocorreu o fato gerador, é indispensável determinar em que ponto do mar territorial encontrava-se o navio ao ser realizada a venda ou o fornecimento.

A estas dificuldades teóricas acrescentam-se as dificuldades práticas para determinar o ponto do território estadual (ponto do mar territorial) a ser considerado para fins de saber qual o local da operação e, portanto, qual o Estado competente. Realmente, em terra é possível implantar pontos físicos claros (marcos de concreto, postes, barreiras de controle de transito etc.), enquanto no mar territorial isto é totalmente inviável na prática (seriam linhas de boias flutuantes? Pequenos faróis cujo feixe de luz indicaria a passagem da fronteira estadual? Seria a tecnológica do GPS? Etc.) ${ }^{243}$.

Nesse contexto, o Supremo Tribunal Federal já firmou jurisprudência quanto à indispensabilidade de edição de lei complementar para dirimir conflito de competência entre os Estados.

A título exemplificativo, cite-se o julgamento da ADIN $n^{\circ} 1.600$, em que foi declarada a inconstitucionalidade do ICMS incidente sobre a prestação de serviços de

\footnotetext{
${ }^{242}$ Saliente-se, por oportuno, que o artigo $27, \S 2^{\circ}$, do Convênio ICMS 66/88 é objeto da ADIN n $54-3$, ainda pendente de julgamento perante o STF.

${ }^{243}$ GRECO, Marco Aurélio. Impossibilidade de cobrar ICMS em operações ocorridas no mar territorial e na zona econômica exclusiva. Revista Dialética de Direito Tributário. São Paulo, n. 133. 2006. p. 74.
} 
transporte aéreo intermunicipal, interestadual e internacional de passageiros ${ }^{244}$. Vale transcrever, por oportuno, o seguinte trecho do Ministro Nelson Jobim:

\begin{abstract}
A LC 87/96, quanto ao transporte de passageiros, possui regras que viabilizam, ou não, a incidência e aplicação dos dispositivos constitucionais mencionados? Entendo ter demonstrado que não.

O legislador infraconstitucional tem a obrigação de produzir normas de solução de conflitos de competência entre as unidades federadas (CF, art. 146, I). Não o fez.

Pelo contrário, disciplinou a matéria inviabilizando a aplicação de regras constitucionais.
\end{abstract}

Portanto, considerando que (i) somente a União detém soberania e competência exclusiva para dispor sobre as águas marítimas e (ii) a lei complementar $n^{\circ}$ 87/96 não estabelece essa área como local em que ocorre a operação relativa à circulação de mercadorias, tampouco contém regras para solucionar conflitos de competência entre os Estados-membros costeiros, somos da opinião de que falece competência aos Estados da federação exigir o ICMS sobre operações mercantis realizadas no mar territorial.

\title{
4.4.2.2. Zona econômica exclusiva e plataforma continental
}

A Constituição Federal prescreve, no seu artigo 20, inciso $\mathrm{V}$, que os recursos naturais da plataforma continental e da zona econômica exclusiva são bens da União.

A zona econômica exclusiva é uma faixa que se estende a partir das 12 milhas do mar territorial e se prolonga até 200 milhas marítimas. Tal área está sujeita a um regime jurídico específico, conforme prescreve o artigo 55, Parte V, da Convenção de Montego Bay $^{245 .}$

Segundo os ensinamentos de ELIANE M. OCTAVIANO MARTINS ${ }^{246}$, a zona econômica exclusiva surgiu para proteger os direitos dos Estados costeiros relativamente à pesca e à extração de recursos vivos, atribuindo aos Estados que antes não tinham direito

\footnotetext{
244 “Constitucional. Tributário. Lei Complementar 87/96. ICMS e sua instituição. Art. 150, II' 155 § 2, VII, "A" e inciso VIII, CF. Conceitos de passageiro e de destinatário do serviço. Fato gerador. Ocorrência. Alíquotas para operações interestaduais e para as operações internas. Inaplicabilidade da fórmula constitucional de partição da receita do ICMS entre os Estados. Omissão quanto a elementos necessários à instituição do ICMS sobre navegação aérea (...)."

245 "Artigo 55 A zona econômica exclusiva é uma zona situada além do mar territorial e a este adjacente, sujeita ao regime jurídico específico na presente Parte, segundo o qual os direitos e a jurisdição do Estado costeiro e os direitos e liberdades dos demais Estados são regidos pelas disposições pertinentes da presente Convenção."

${ }^{246}$ MARTINS, Eliane M. Octaviano. Curso de Direito Marítimo. São Paulo: Manole, 2005. p. 101.
} 
relativamente à exploração marinha direitos econômicos preferenciais no que tange à pesca e à extração e conservação de recursos vivos.

Diversamente do que ocorre com o mar territorial, o Brasil não possui soberania sobre a zona econômica exclusiva, mas, nos termos do artigo $7^{\circ}$ da Lei $n^{\circ} 8617 / 93$,

[...] direitos de soberania para fins de exploração e aproveitamento, conservação e gestão dos recursos naturais, vivos ou não vivos, das águas sobrejacentes ao leito do mar, do leito do mar e seu subsolo, e no que se refere a outras atividades com vistas à exploração e ao aproveitamento da zona para fins econômicos.

A plataforma continental, por sua vez, compreende "o leito e o subsolo das áreas submarinas que se estendem além do seu mar territorial, em toda a extensão do prolongamento natural do seu território terrestre, até ao bordo exterior da margem continental, ou até uma distância de 200 milhas marítimas das linhas de base a partir das quais se mede a largura do mar territorial, nos casos em que o bordo exterior da margem continental atinja essa distância" (CNDUN, artigo 76, §1 ${ }^{\circ}$ ).

Na plataforma continental, o Estado costeiro também exerce direitos de soberania para fins de exploração dos recursos naturais, os quais compreendem os recursos minerais e outros recursos não vivos do leito do mar e subsolo, bem como os organismos vivos pertencentes a espécies sedentárias, nos termos do artigo 12, parágrafo único, da Lei $\mathrm{n}^{\circ}$ 8617/93. Ademais, o Estado costeiro possui a prerrogativa de autorizar as perfurações visando à prospecção de recursos petrolíferos na área compreendida pela plataforma continental.

Confira-se abaixo quadro ilustrativo das áreas marítimas acima mencionadas:

\section{LIMITES DO MAR}

1 MILHA NÁUTICA $=1.852 \mathrm{~m}$

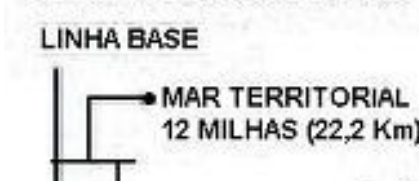

ZONA ECONÖMICA EXCLUSIVA (ZEE)

200 MILHAS $(370,4 \mathrm{Km})$

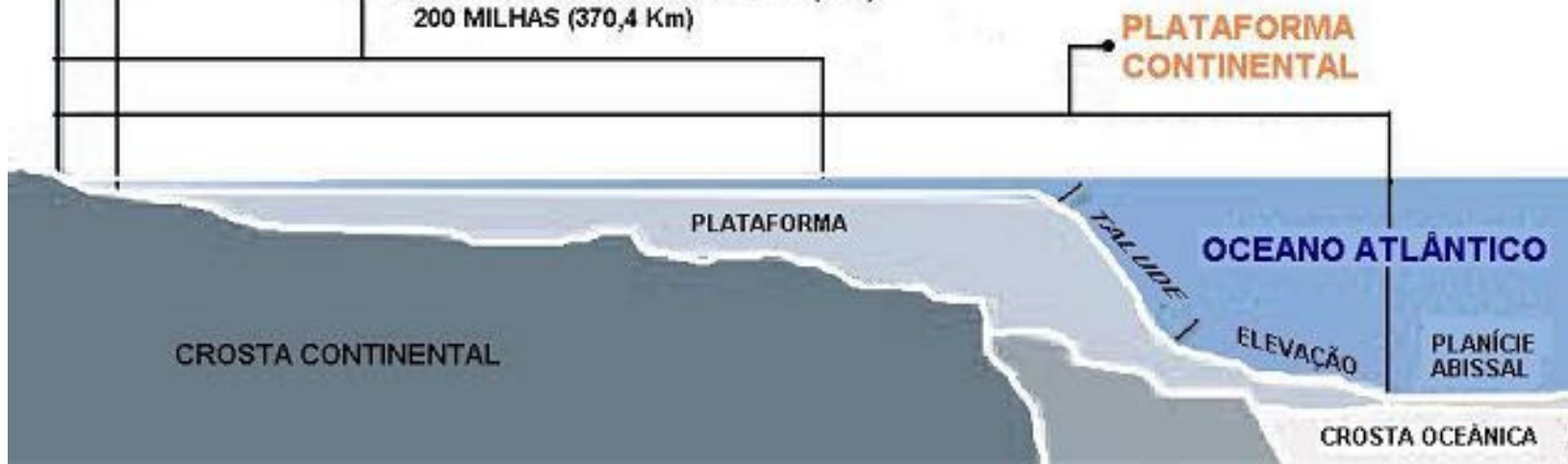

Fonte: Comissão Interministerial para os Recursos do Mar 
Importante salientar que, diversamente do que ocorre com o mar territorial, que pertence à União, apenas os recursos minerais extraídos da zona econômica exclusiva e da plataforma continental são de domínio desse ente federativo, mas não as áreas onde estão estabelecidas, que não integram o território brasileiro.

Nesse exato sentido, vale transcrever as lições de SACHA CALMON NAVARRO $\mathrm{COÊLHO}^{247}$, ao discorrer sobre a constitucionalidade da Lei ${ }^{\circ} 12.734 / 2012$, que dispõe sobre repartição dos royalties do petróleo. Segundo os ensinamentos do Professor, é equivocado o emprego da expressão "Estados produtores e não produtores" de petróleo, quando a extração ocorrer na plataforma continental e na zona econômica exclusiva, justamente porque tais áreas marítimas não pertencem ao território brasileiro:

\begin{abstract}
Indiferente à limitação legal, a mídia nacional - ecoando o discurso político frequentemente fala dos Estados "produtores" e "não produtores" de petróleo e gás. Entretanto, quando se trata de recursos naturais da plataforma continental e da zona de exploração econômica exclusiva a terminologia é absolutamente imprópria, e falseia a repartição dos royalties do petróleo entre a União, Estados e Municípios. Na verdade, o Brasil não tem territórios, nem soberania sobre o mar da plataforma continental e do leito do oceano. Como pessoa de direito público internacional, é apenas titular da prerrogativa de explorar, com exclusividade, os recursos naturais nele existentes, segundo a Convenção Internacional em comento. E onde não há território nem soberania descabe falar em Estados produtores e não produtores.
\end{abstract}

Por esse motivo, nenhum Estado da federação possui competência para editar normas sobre tais áreas, razão pela qual as operações mercantis de circulação de mercadorias realizadas nos navios ou plataformas de petróleo que se encontram nessas áreas não são alcançadas pelo ICMS. Nesse diapasão, vale transcrever as observações de IVES GANDRA DA SILVA MARTINS:

Por fim, há que se lembrar que as explorações de bens e serviços na plataforma continental estão fora da incidência tributária daqueles impostos cujos fatos geradores ocorram a partir da localização dos estabelecimentos explorados, como é o caso do ISS e poderá ser do ICMS, eis que sua produção se faz em bens da União, mas não em território municipal ou estadual, como, de resto, já acontece hoje com a exploração de petróleo nas referidas plataformas ${ }^{248}$.

${ }^{247}$ COÊLHO, Sacha Calmon Navarro. Royalties do Petróleo. A lei é constitucional. ,Belo Horizonte: Editora Luminus, 2013.. p. 10.

${ }^{248}$ MARTINS, Ives Gandra. Comentários à Constituição do Brasil , p. 71. 


\subsubsection{A interpretação do artigo $20, \mathbf{1}^{\circ}$, da Constituição Federal}

Conforme já demonstrado, o artigo 20, $1^{\circ}$, da Constituição Federal assegura, “[...] aos Estados, ao Distrito Federal e aos Municípios, bem como a órgãos da administração direta da União, participação no resultado da exploração de petróleo ou gás natural, de recursos hídricos para fins de geração de energia elétrica e de outros recursos minerais no respectivo território, plataforma continental, mar territorial ou zona econômica exclusiva, ou compensação financeira por essa exploração".

Há quem entenda que o referido dispositivo constitucional, ao empregar o vocábulo "respectivo", teria incluído a plataforma continental, o mar territorial e a zona econômica exclusiva como áreas integrantes dos Estados, Distrito Federal e Municípios.

Entretanto, essa interpretação é equivocada. O referido enunciado constitucional tem por destinatário a União, que tem o dever de partilhar as receitas decorrentes da exploração desses recursos naturais (participações governamentais), inclusive sobre as áreas que possuem soberania (mar territorial) e direitos de soberania (zona econômica exclusiva e plataforma continental) com os Estados, o Distrito Federal e os Municípios.

Nesse diapasão, vale transcrever, mais uma vez, as oportunas lições de SACHA CALMON NAVARRO COÊLHO ${ }^{249}$ :

\footnotetext{
Como se vê, a participação dos Estados e Municípios se dá de duas maneiras: primeiro, privativamente, quando a exploração ocorrer nos respectivos territórios; e, segundo, em igualdade entre eles (princípio da isonomia) quando a exploração ocorrer na plataforma continental, em mar territorial ou em zona econômica exclusiva, porque não circunscritas no 'respectivo território', como ressalta o parágrafo. Do contrário, a expressão seria desnecessária.

Exemplos: (1) Os poços de petróleo terrestres no recôncavo baiano geram royalties para a União, o Estado da Bahia e para os Municípios onde situados. (2) O minério extraído em Congonhas do Campo, Minas Gerais, gera royalties para a União, o Estado de Minas Gerais e, óbvio, para o Município de Congonhas, excluídos os demais. Consequentemente, o petróleo, o gás e o minério que saem do subsolo marinho, abaixo do mar territorial, da plataforma continental ou da zona econômica exclusiva haverão de ser repartidos entre todos os Estados e Municípios de forma igual, em nome de isonomia federativa.
}

A Constituição Federal estabeleceu, destarte, uma partilha dessas receitas justamente porque os Estados, o Distrito Federal e os Municípios não detêm competência sobre essas áreas marítimas.

${ }^{249}$ COÊLHO, Sacha Calmon Navarro. Royalties do Petróleo, p. 11. 
A competência da União sobre essas áreas marítimas é tão clara que a Lei $\mathrm{n}^{\circ}$ 9.478/97 (Lei do Petróleo), em conformidade com o referido enunciado constitucional, estabeleceu os critérios de participação desses entes federativos na arrecadação das participações governamentais.

Nesse sentido, vale transcrever as conclusões de AIRES FERNANDINO BARRETO acerca do alcance da norma veiculada pelo artigo $20, \S 1^{\circ}$, da Carta Maior em artigo que aborda a possibilidade de incidência do ISS sobre atividades desenvolvidas em águas marítimas:

\begin{abstract}
Em suma, o art. 20, parágrafo $1^{\circ}$, da Constituição, é norma que tem por destinatária a União, pessoa jurídica de Direito Público, impondo-lhe partilhar receitas que está preordenada a obter, por meio da exploração econômica de recursos naturais, inclusive os que jazem em áreas sobre as quais o Estado Brasileiro tem domínio e soberania exercidos por meio dela (União, no sentido do Estado Federado) e reconhecido pelas demais nações, segundo as normas do Direito das gentes ${ }^{250}$.
\end{abstract}

Logo, ainda que a extração do petróleo pudesse ser considerada uma operação relativa à circulação de mercadoria, falece competência a qualquer Estado-membro da federação exigir o ICMS sobre operações mercantis realizadas nas áreas marítimas.

\title{
4.5. Critério quantitativo
}

Conforme exposto anteriormente, a base de cálculo é entendida como a grandeza instituída que se destina, primordialmente, a dimensionar a intensidade do comportamento constante no núcleo do fato jurídico. Existem três funções distintas para a chamada base calculada, quais sejam: (a) medir as proporções reais do fato, ou função mensuradora, (b) compor a específica determinação da dívida, ou função objetiva e (c) confirmar, infirmar ou afirmar o correto elemento material do antecedente normativo, ou função comparativa.

A base de cálculo do ICMS mercantil foi definida pelo legislador complementar como o "valor da operação" de que decorre a saída da mercadoria (artigo 13, inciso I, da Lei Complementar $n^{\circ} 87 / 96^{251}$ ). Tal grandeza está em sintonia com o critério material do ICMS mercantil.

\footnotetext{
${ }^{250}$ BARRETO, AIRES Fernandino. ISS - Não incidência sobre atividades desenvolvidas em águas marítimas Revista Dialética de Direito Tributário. São Paulo, n. 200. 2012

251 “Art. 13. A base de cálculo do imposto é:

I - na saída da mercadoria prevista nos incisos I, III e IV do art. 12, o valor da operação.”
} 
O artigo $4^{\circ}$, inciso XIII, $\S 5^{\circ}$, da Lei Estadual $n^{\circ} 4.117 / 03$ prescreve, por sua vez, que a base de cálculo do ICMS incidente na extração do petróleo é o "preço de referência", compreendido como a "média ponderada dos seus preços de venda praticados pelo concessionário, em condições normais de mercado ou ao seu preço mínimo estabelecido pela ANP, aplicando-se o que for maior". Passamos a analisar se essa grandeza mensura uma suposta operação mercantil de venda do petróleo pela União ao concessionário extrator.

Pela análise do enunciado em questão, nota-se, inicialmente, que o legislador estadual, ao eleger o "preço de referência" como base de cálculo do ICMS, produziu enunciado em desacordo com aquele veiculado pela Lei Complementar $n^{\circ}$ 87/96 (valor da operação de que decorre a saída da mercadoria), o que por si só comprova a inadequação da grandeza escolhida para dimensionar a intensidade do comportamento constante no núcleo do fato jurídico.

Deveras, o preço de referência adotado para fins de cálculo do ICMS na hipótese de extração de petróleo se assemelha com a sistemática de pauta de valores, na medida em que busca reproduzir o valor médio do preço de venda praticado pelo concessionário em condições de mercado.

Contudo, a fixação da base de cálculo do ICMS com apoio em pauta fiscal ou de valores somente é admitida nas hipóteses previstas no artigo 148 do $\mathrm{CTN}^{252}$, a saber: quando houver omissão ou não merecerem fé as declarações ou esclarecimentos prestados, ou os esclarecimentos prestados ou os documentos expedidos pelo sujeito passivo ou pelo terceiro legalmente obrigado.

Nesse sentido, a Primeira Seção do Superior Tribunal de Justiça sedimentou o entendimento quanto à impossibilidade de fixação da base de cálculo do ICMS com apoio em pautas fiscais. Confira-se:

TRIBUTÁRIO. ICMS. BASE DE CÁLCULO. SUA FIXAÇÃO ATRAVÉS DE PAUTAS DE PREÇOS OU VALORES. INADMISSIBILIDADE.

Em face do nosso direito (Del 406/1968, art. 2, I), é inadmissível a fixação da base de cálculo do ICMS com apoio em pautas de preços ou valores (pautas

\footnotetext{
252 “Art. 148. Quando o cálculo do tributo tenha por base, ou tem em consideração, o valor ou o preço de bens, direitos, serviços ou atos jurídicos, a autoridade lançadora, mediante processo regular, arbitrará aquele valor ou preço, sempre que sejam omissos ou não mereçam fé as declarações ou os esclarecimentos prestados, ou os documentos expedidos pelo sujeito passivo ou pelo terceiro legalmente obrigado, ressalvada, em caso de contestação, avaliação contraditória, administrativa ou judicial.”
} 
fiscais), porquanto aquela (base de cálculo do tributo) é o valor da operação de que decorrer a saída da mercadoria.

A pauta de valores só se admite nos casos previstos no art. 148 do CTN, em que, mediante processo regular, seja arbitrada a base de cálculo, quando inidôneos os documentos e declarações prestadas pelo contribuinte.

O direito tributário repugna a adoção de base de cálculo que esteja, dissociada do efetivo valor econômico do fenômeno tributário (STJ, $1^{\text {a }}$ Seção, EMBARGOS DE DIVERGÊNCIA EM RECURSO ESPECIAL 33808/SP, Ministro DEMÓCRITO REINALDO, DJ 20/10/97).

A segunda conclusão que sobressai pela análise do enunciado prescritivo em questão é que o legislador ordinário elegeu como base de cálculo do ICMS a mesma grandeza prevista para fins de apuração dos royalties, estabelecida no artigo $7^{\circ}$ do Decreto $\mathrm{n}^{\circ} 2.705 / 98$ :

\footnotetext{
Art. $7^{\circ} \mathrm{O}$ preço de referência a ser aplicado a cada mês ao petróleo produzido em cada campo durante o referido mês, em reais por metro cúbico, na condição padrão de medição, será igual à média ponderada dos seus preços de venda praticados pelo concessionário, em condições normais de mercado, ou ao seu preço mínimo estabelecido pela ANP, aplicando-se o que for maior.
}

Infere-se, entretanto, que a base de cálculo sobre a qual se apuram os denominados royalties não pode ser compreendida como o "preço de aquisição" do petróleo "pago" pelo concessionário à União. Vale dizer, não há, também sob essa perspectiva, nenhuma aquisição onerosa, o que corrobora a inexistência de transferência de propriedade desse bem público.

Se houvesse, de fato, aquisição pelo concessionário do petróleo extraído, todo o recurso proveniente dos royalties seria transferido integralmente à União, o que não ocorre, porquanto essa participação governamental é, por imposição constitucional, partilhada entre os Estados, Distrito Federal, Municípios e órgãos da administração direta da União, como já demonstramos.

Para reforçar ainda mais o descompasso entre a base de cálculo veiculada pela Lei $\mathrm{n}^{\circ}$ 4.117/03 e o critério material da hipótese de incidência do ICMS, vale relembrar que o objeto do contrato de concessão de petróleo não é esse bem propriamente dito, mas sim a sua exploração e produção, razão pela qual o artigo 12 do Decreto ${ }^{\circ}$ 2.705/98 estabelece que o pagamento dos royalties se dá em função da multiplicação de um percentual do volume de produção pelo preço de referência:

Art 12. O valor dos royalties, devidos a cada mês em relação a cada campo, será determinado multiplicando-se o equivalente a dez por cento do volume total da produção de petróleo e gás natural do campo durante esse mês pelos seus 
respectivos preços de referência, definidos na forma do Capítulo IV deste Decreto.

$\S 1^{\circ}$ A ANP poderá, no edital de licitação para um determinado bloco, prever a redução do percentual de dez por cento definido neste artigo até um mínimo de cinco por cento do volume total da produção, tendo em vista os riscos geológicos, as expectativas de produção e outros fatores pertinentes a esse bloco.

Logo, a base de cálculo eleita pelo legislador ordinário estadual (preço de referência) não mede as proporções reais do fato (valor da operação mercantil, ou seja, o preço pela "aquisição" do petróleo pelo concessionário).

Cumpre também destacar que a matéria relativa à fixação da base de cálculo é reservada à lei complementar, nos termos do artigo 155, §2, XII, alínea “i”, da Constituição Federal. E a Lei Complementar n 87/96 não fixou o preço de referência do petróleo como base de cálculo do ICMS na hipótese de venda de mercadorias. Assim, o enunciado-enunciado veiculado pela Lei $\mathrm{n}^{\circ} 4.117 / 03$, que trata sobre o critério espacial do ICMS, incidente na extração do petróleo, não foi produzido em conformidade com o enunciado complementar acima mencionado.

\subsection{Critério pessoal}

Caso a extração do petróleo pudesse ser considerada uma operação relativa à circulação de mercadoria, quem poderia ser eleito como sujeito passivo do ICMS? Seria a União, que supostamente aliena esse bem público, ou o extrator, que foi eleito como contribuinte desse imposto pelo legislador ordinário estadual (artigo 15, $\S 1^{\circ}$, inciso I, da Lei $\left.n^{\circ} 4117 / 03^{253}\right)$ ? É o que passaremos a verificar.

\subsubsection{União e a imunidade recíproca}

Se a extração de petróleo pudesse ser enquadrada como uma operação relativa à circulação de mercadoria, somente poderia ser sujeito passivo da relação jurídica tributária, nos termos do artigo $4^{\circ}$ da Lei Complementar $n^{\circ}$ 87/96, a União, na condição de "alienante" da "mercadoria" petróleo.

\footnotetext{
253 “Art 15 - Contribuinte é qualquer pessoa, física ou jurídica, que realize, com habitualidade ou em volume que caracterize intuito comercial, operação de circulação de mercadoria ou prestação de serviços descritos com o fato gerador do imposto, observado o disposto no $\S 2^{\circ}$ deste artigo.

$\S 1^{\circ}$ - Incluem-se entre os contribuintes do imposto:

I - O comerciante, o industrial, o produtor e o extrator, inclusive de petróleo."
} 
Nessa hipótese, porém, emerge um obstáculo constitucional que impede que a União seja eleita como sujeito passivo da obrigação tributária: a imunidade recíproca prevista no artigo 150, inciso VI, alínea "a", da Constituição Federal, o qual determina que a "União, os Estados e os Municípios não podem instituir impostos sobre o patrimônio, a renda e os serviços uns dos outros".

Com efeito, a imunidade recíproca decorre do pacto federativo e do princípio da isonomia das pessoas políticas, como bem observou ROQUE ANTÔNIO CARRAZA ${ }^{254 .}$ De acordo com o autor, se os entes políticos pudessem cobrar impostos uns dos outros, a forma federativa do Estado, que constitui uma das cláusulas pétreas insculpida no artigo $60, \S 4^{\circ}$, da Constituição Federal, estaria comprometida, assim como a igualdade entre essas pessoas, na medida em que haveria uma sobreposição de uma sobre as outras.

Saliente-se, por oportuno, que ainda persiste o debate acerca da aplicabilidade dessa regra imunizante com relação aos impostos cujo encargo financeiro é transferido a terceiros, como é o caso do ICMS e do IPI.

O Supremo Tribunal Federal vem se posicionando no sentido de que a imunidade em apreço alcance apenas o contribuinte de direito e não o contribuinte de fato, conforme se infere da seguinte ementa:

\begin{abstract}
TRIBUTÁRIO. ICMS. AQUISIÇÕES DE BENS. MUNICÍPIO. CONTRIBUINTE DE FATO. IMUNIDADE RECÍPROCA. ART. 150, VI, A, DA CONSTITUIÇÃO. INAPLICABILIDADE. AGRAVO IMPROVIDO. I - A imunidade do art. 150, VI, a, da Constituição somente se aplica ao imposto incidente sobre serviço, patrimônio ou renda do próprio ente beneficiado, na qualidade de contribuinte de direito. II - Como o Município não é contribuinte de direito do ICMS incidente sobre aquisições de bens, não tem o benefício da imunidade em questão, uma vez que esta não alcança o contribuinte de fato. Precedentes. III - Agravo regimental improvido (ARE 690382 AgR / RS, Ministro Relato RICARDO LEWANDOWSKI, DJ de 17/12/12).
\end{abstract}

O Supremo Tribunal Federal reconheceu a repercussão geral no tocante à regra imunizante prevista no artigo 150, inciso VI, "c", da Constituição Federal ao analisar caso em que entidade de assistência social busca a imunidade do ICMS cobrado de seus fornecedores (contribuintes de direito) a ela repassados como consumidora (contribuinte de fato):

TRIBUTÁRIO - IMUNIDADE - ENTIDADES DE ASSISTÊNCIA SOCIAL ICMS - AQUISIÇÃO NO MERCADO INTERNO - CONTRIBUINTE DE

FATO. I. A controvérsia relativa à abrangência da imunidade prevista no art.

${ }^{254}$ CARRAZA, Roque Antônio. Curso de Direito Constitucional Tributário,p. 762. 
150, inciso VI, “c”, da Constituição Federal a instituição de assistência social, quando da aquisição de bens no mercado interno, na qualidade de contribuinte de fato, ultrapassa os limites subjetivos das partes. II. Repercussão geral reconhecida (RE 608872 RG, Ministro Relator Dias Toffolo. DJ de 01/08/11).

Embora essa questão não tenha sido pacificada pela Suprema Corte, entendemos que o fato de o repasse financeiro desse imposto ser suportado pelo "adquirente do petróleo" (in casu, o concessionário) constitui um critério extrínseco da relação jurídica tributária, o qual não pode ser invocado para afastar a aplicação da regra imunizante contemplada no artigo 150, inciso VI, alínea "a", da Constituição Federal.

Deve-se também ressaltar que a extração do petróleo não se amolda a nenhuma das hipóteses previstas no artigo $150, \S 3^{\circ}$, da Constituição Federal ${ }^{255}$, que excepcionam a imunidade recíproca, quais sejam: (i) desenvolvimento de atividades reguladas pelo Direito Civil; (ii) atividades nas quais os beneficiários pagam preço público ou tarifa ou (iii) a impostos devidos sobre bens imóveis.

De fato, a exploração da atividade econômica relativa ao petróleo não está submetida ao regime de direito civil, mas sim ao regime de direito púbico, eis que essa atividade é monopólio da União.

No tocante à segunda hipótese, não há, por parte do concessionário extrator de petróleo, pagamento de preço público ou tarifa nas atividades de exploração em si.

Com efeito, o preço público é a contrapartida de uma prestação contratual voluntária. A título exemplificativo, ROQUE ANTÔNIO CARRAZA afirma que paga um preço quem, voluntariamente, adquire do Estado viaturas inservíveis, postas em licitação, ou quem loca um imóvel público ${ }^{256}$. Em ambas as situações, há livre negociação entre as partes, que deflui da própria relação jurídica contratual, submetida, portanto, ao regime de direito privado.

Como já verificado, o petróleo não é objeto do contrato de concessão. O concessionário não pactua com a União a "transferência" da sua propriedade, que é adquirida de forma originária pelo concessionário por determinação constitucional, mas apenas o direito de explorá-lo e produzi-lo, caso esse recurso mineral seja descoberto.

A corroborar o quanto exposto, os royalties não possuem, a nosso ver, a natureza de preço público, pois a contraprestação para o direito de exploração de petróleo não decorre

\footnotetext{
255 “§ $3^{\circ}$ - As vedações do inciso VI, “a”, e do parágrafo anterior não se aplicam ao patrimônio, à renda e aos serviços, relacionados com exploração de atividades econômicas regidas pelas normas aplicáveis a empreendimentos privados, ou em que haja contraprestação ou pagamento de preços ou tarifas pelo usuário, nem exonera o promitente comprador da obrigação de pagar imposto relativamente ao bem imóvel."

${ }^{256}$ CARRAZA, Roque Antônio. Curso de Direito Constitucional Tributário, p. 557.
} 
de um acordo de vontades entre as partes contratantes (ANP e concessionário), e sim de lei (regime de direito público).

A terceira hipótese que excepciona a regra da imunidade recíproca (impostos devidos sobre bens imóveis) não se refere ao ICMS, motivo pelo qual não iremos dela discorrer, por fugir ao escopo do presente estudo.

Portanto, entendemos que a União não poderia compor o polo passivo da relação jurídica tributária caso a extração do petróleo fosse verdadeiramente uma operação relativa à circulação de mercadoria, em razão da regra imunizante prevista no artigo 150, inciso VI, alínea "a", da Constituição Federal.

\subsection{2. $O$ extrator como contribuinte}

Como aduzido anteriormente, somente o comerciante, o industrial ou o produtor, dotados de personalidade jurídica, que efetivamente realize operações relativas à circulação de mercadorias, podem ser considerados contribuintes do ICMS ora analisado.

No momento da extração do petróleo, o extrator não pratica, obviamente, nenhuma operação relativa à circulação de mercadorias, motivo pelo qual não é possível enquadrá-lo também como contribuinte do ICMS, como prevê o artigo 15, inciso I, da Lei no 4.117/03:

\footnotetext{
Art 15 - Contribuinte é qualquer pessoa, física ou jurídica, que realize, com habitualidade ou em volume que caracterize intuito comercial, operação de circulação de mercadoria ou prestação de serviços descritos com o fato gerador do imposto, observado o disposto no $\S 2^{\circ}$ deste artigo.

$\S 1^{\circ}$ - Incluem-se entre os contribuintes do imposto:

I - O comerciante, o industrial, o produtor e o extrator, inclusive de petróleo.
}

Cumpre ainda ressaltar que a definição de contribuintes do ICMS é, por determinação constitucional (artigo 155, §2º XII, alínea “a”, da Constituição Federal) matéria reservada à lei complementar. E a Lei Complementar $n^{\circ} 87 / 96$, no seu artigo $4^{\circ}$, não incluiu o extrator no rol dos contribuintes desse imposto, mas apenas (i) as pessoas físicas ou jurídicas que realizem, com habitualidade ou em volume que caracterize intuito comercial, operações de circulação de mercadorias ou prestação de serviços tributáveis; (ii) o importador de mercadorias ou bens do exterior; (iii) o destinatário do serviço prestado no exterior ou cuja prestação tenha se iniciado no exterior; (iii) o licitador de mercadorias ou bens apreendidos ou abandonados; (iv) o adquirente de lubrificantes e combustíveis derivados de petróleo e eletricidade oriundos de outro Estado, quando não destinados à comercialização ou à industrialização. 
Verifica-se, assim, que o legislador ordinário estadual não observou o referido enunciado complementar ao eleger o extrator como contribuinte do ICMS. Além disso, acabou instituindo uma verdadeira substituição tributária, na medida em que conferiu a responsabilidade pelo pagamento do imposto ao concessionário, que seria o adquirente da "mercadoria" e não ao seu "alienante", que seria a União.

Logo, o legislador ordinário estadual, ao exercitar a competência tributária, desrespeitou também o enunciado previsto no artigo $155, \S 2^{\circ}$, inciso XII, alínea "b", da Constituição Federal, o qual exige a veiculação de lei complementar para dispor sobre substituição tributária.

\subsection{O princípio da não cumulatividade do ICMS e a extração do petróleo}

\subsubsection{Princípios constitucionais}

Partindo da premissa de que o sistema jurídico é composto de normas, não se pode conceber a existência de outros elementos no interior do sistema distintos das normas jurídicas. Essa á a conclusão de PAULO DE BARROS CARVALHO ao tratar sobre os princípios jurídicos:

O corolário natural de tudo quanto se expôs é que o direito positivo, formado unicamente por normas jurídicas, não comportaria a presença de outras entidades, como, por exemplo, princípios. Estes não existem ao lado de normas, co-participando da integridade do ordenamento. Não estão ao lado das unidades normativas, justapondo-se ou contrapondo-se a elas. Acaso estivessem, seriam formações linguísticas portadoras de uma estrutura sintática. E qual é esta configuração lógica? Ninguém, certamente, saberá responder a tal pergunta, porque "princípios" são "normas jurídicas" carregadas de forte conotação axiológica. É o nome que se dá a regras do direito positivo que introduzem valores relevantes para o sistema, influindo rigorosamente sobre a orientação de setores de ordem jurídica ${ }^{257}$.

De acordo com os ensinamentos de ROQUE ANTÔNIO CARRAZA,

[...] princípio jurídico é um enunciado lógico, implícito ou explícito, que, por sua generalidade, ocupa posição de preeminência nos vastos quadrantes de Direito e, por isso mesmo, vincula, de modo inexorável, o entendimento e a aplicação das normas jurídicas que com ele se conectam ${ }^{258}$.

${ }^{257}$ CARVALHO, Paulo de Barros. Direito Tributário, linguagem e método, p. 257.

${ }^{258}$ CARRAZA, Roque Antônio. Curso de Direito Constitucional Tributário, p. 44. 
Os princípios diferem das regras. Existem vários critérios que distinguem essas espécies normativas. Para ROBERT ALEXY ${ }^{259}$, tanto os princípios como as regras são normas, porque "ambos dizem o que deve ser". Segundo o autor alemão, os princípios são "mandamentos de otimização", pois "ordenam que algo seja realizado na maior medida possível dentro das possibilidades jurídicas e fáticas existentes", ao passo que as regras "são normas que são sempre satisfeitas ou não satisfeitas".

De acordo com o entendimento do autor alemão, os princípios são normas que visam à realização dos valores sociais considerados importantes por uma comunidade no maior grau possível, possuindo, destarte, um caráter finalístico. Não são válidas ou inválidas. As regras, por outro lado, prescrevem comportamento, podendo ser válidas ou inválidas.

O caráter finalístico dos princípios foi ressaltado por HUMBERTO ÁVILA, para quem

As regras são normas imediatamente descritivas, na medida em que estabelecem obrigações, permissões e proibições mediante a descrição da conduta a ser cumprida. Os princípios são normas imediatamente finalísticas, já que estabelecem um estado de coisas cuja promoção gradual depende dos efeitos decorrentes da adoção de comportamentos a ela necessários ${ }^{260}$.

Importante consignar também o entendimento de PAULO DE BARROS CARVALHO, para quem o termo princípio é utilizado para designar indistintamente tanto os valores como os chamados limites objetivos, os quais estabelecem procedimentos de aplicação de normas com o fim de buscar a realização de valores:

\footnotetext{
Os limites objetivos distinguem-se dos valores, pois são concebidos para atingir certas metas, certos fins. Estes, sim, assumem o porte de valores. Aqueles limites não são valores, são procedimentos, se os considerarmos em si mesmo, mas voltam-se para realizar valores, de forma indireta, mediata, que são os fins para os quais estão preordenados os procedimentos. Os princípios de direito tributário, por seu turno, geralmente se expressam como "limites objetivos", postos como sobre-regras que visam implementar os valores estipulados no ordenamento jurídico ${ }^{261}$.
}

Dentre os diversos objetivos realizadores de valor, destacamos os princípios da legalidade, da anterioridade, da irretroatividade da lei tributária, dentre outros. Todos eles

\footnotetext{
${ }^{259}$ ALEXY, Robert. Teoria dos Direitos Fundamentais. São Paulo: Malheiros, 2008. p. 87.

${ }^{260}$ ÁVILA, Humberto. Teoria dos Princípios: da definição à aplicação dos princípios jurídicos. $14^{\mathrm{a}} \mathrm{ed}$. São Paulo: Malheiros Editores, 2013, p 203.

${ }^{261}$ CARVALHO, Paulo de Barros. Direito Tributário, linguagem e método, p. 292.
} 
operam para a realização do valor segurança jurídica, sobreprincípio que se irradia por todo o ordenamento jurídico.

Os princípios apresentam-se, normalmente, na forma de preceitos constitucionais, mas podem revelar-se também como fruto de derivação lógica das formulações expressas do direito positivo, como ocorre com o primado da justiça, da segurança jurídica, da certeza do direito etc.

Portanto, temos para nós que os princípios são mandamentos estruturais e básicos do sistema jurídico, dotados de intensa carga axiológica e destinados a orientar toda a atividade interpretativa, como a direção de construção dos comandos normativos.

Os princípios assumem ainda importante papel na demarcação da competência tributária. TÁCIO LACERDA GAMA afirma que “os princípios tributários são proposições prescritivas que integram a norma de competência, condicionando a forma e a matéria das normas que prescrevem, direta ou indiretamente, a instituição, a arrecadação e a fiscalização de tributos" 262 .

CRISTIANE MENDONÇA, por sua vez, observa que os princípios constitucionais fixam valores e limites objetivos que devem ser observados pelos órgãos legislativos ao instituir a regra-matriz de incidência:

\begin{abstract}
Os princípios constitucionais tributários, denominados pelo legislador constituinte como "limitações constitucionais ao poder de tributar" auxiliam na demarcação da competência legislativo-tributária, seja fixando valores que devem ser realizados e densificados na norma jurídico-tributária, seja estipulando limites objetivos que hão de ser respeitados quando da edição da referida unidade normativa ${ }^{263}$.
\end{abstract}

De acordo com a autora, o artigo 150, inciso I, da Constituição Federal prescreve verdadeiro limite formal à "ação criativa" dos órgãos legislativos das pessoas políticas, ao prescrever que o veículo introdutor de tributos no sistema seja a lei.

Da mesma forma, o artigo 150, inciso II, que veda tratamento desigual entre contribuintes que se encontrem em situação equivalente, impõe limite ao legislador infraconstitucional para a criação de dispositivos que criem desigualdades entre iguais. Ao comentar referido princípio, CRISTIANE MENDONÇA exemplifica:

Visivelmente inconstitucionais seriam, por exemplo, os enunciados prescritivos da regra-matriz do imposto sobre a renda que, apesar de terem sido introduzidos no sistema por órgão competente e por meio de procedimento próprio (fato

${ }^{262}$ GAMA, Tácio Lacerda. Competência tributária, fundamentos para uma teoria da nulidade, p. 250.

${ }^{263}$ MENDONÇA, Cristiane. Competência Tributária, p. 156. 
jurídico suficiente), estipulassem uma alíquota triplicada para os advogados formados pela Universidade do Espírito Santo, ou, ainda, para os advogados que ocupam o cargo de procurador do Estado ${ }^{264}$.

O princípio da capacidade contributiva, insculpido no artigo $145, \S 1^{\circ}$, da Carta Maior, também é de observância obrigatória pelo legislador tributário federal, estadual, distrital e municipal para a instituição dos impostos, que deverão, sempre que possível, atribuir caráter pessoal e graduá-los segundo a capacidade econômica do contribuinte.

Os princípios limites-objetivos também restringem a competência legislativotributária das pessoas políticas, tais como o princípio da irretroatividade da norma tributária, prescrito no artigo 150, III, “a”, da Constituição Federal, que estabelece a cobrança de tributos relativamente a fatos geradores ocorridos antes do início da vigência da lei ${ }^{265}$, e o princípio da anterioridade, contemplado no artigo 150, III, “b”, o qual veda a cobrança de tributos no mesmo exercício que os instituiu ou aumentou.

Feitas essas considerações iniciais sobre os princípios e a importância deles para a demarcação da competência tributária, passamos a discorrer sobre o princípio da não cumulatividade do ICMS.

\subsubsection{Breves considerações sobre o princípio da não cumulatividade}

Conforme exposto anteriormente, a Constituição da República, cuidando da instituição do ICMS, prescreve que este será não cumulativo (art. 155, § 2º I). Erigiu, assim, princípio constitucional, cujo alcance não pode ser reduzido nem anulado por normas infraconstitucionais.

Sendo um princípio constitucional, a amplitude da não cumulatividade somente poderá ser contida por enunciados previstos no próprio texto constitucional, o qual prescreve no artigo $155, \S 2^{\circ}$, II, "a" e "b" ${ }^{266}$, que apenas nos casos de isenção ou não

\footnotetext{
${ }^{264}$ MENDONÇA, Cristiane. Competência Tributária, p. 159.

${ }^{265}$ CRISTIANE MENDONÇA enuncia esse limite-objetivo da seguinte forma: “Antecedente: Se for União, Estado, Distrito Federal e Município no Estado Brasileiro no tempo X. Consequente: deve-ser a autorizaçãopermissão para a edição da regra-matriz de incidência das espécies tributárias previstas no texto constitucional e a previsão de cobrança do tributo criado relativamente a fatos sociais ocorridos antes da vigência da lei" (MENDONÇA, Cristiane. Competência Tributária, p. 168).

266 "Art. 155 (...)

$\S 2^{\circ}$. O imposto previsto no inciso II atenderá o seguinte:

(...)

II - a isenção ou não-incidência, salvo determinação em contrário da legislação:

a) não implicará crédito para compensação com o montante devido nas operações ou prestações seguintes;

b) acarretará a anulação do crédito relativo às operações anteriores."
} 
incidência do ICMS a operação relativa à circulação de mercadoria não será geradora do direito ao crédito.

Somente as operações dessa natureza, que se encontrarem fora do campo de incidência da regra-matriz desse imposto, em princípio, também não ensejarão a incidência da regra-matriz do direito ao crédito. Em todas as demais operações relativas à circulação de mercadorias que possam ser subsumidas à hipótese de percussão do tributo, haverá nascimento de crédito.

A não cumulatividade configura mandamento estrutural básico do sistema tributário, que orienta a atividade do legislador ordinário ao instituir a regra-matriz de incidência do ICMS. Tal princípio, que é limite objetivo e não um valor, como sustenta PAULO DE BARROS CARVALHO ${ }^{267}$, auxilia na delimitação constitucional da competência tributária, bem como na determinação da possibilidade constitutiva da norma individual e concreta, sendo vedada sua inobservância, de modo direto ou por via oblíqua, pelo legislador complementar, pelo ordinário e, muito menos, pelo aplicador do direito.

A não cumulatividade não encerra mera sugestão do legislador constituinte para orientar as entidades tributantes. É diretriz básica, sem observância da qual se quebra a homogeneidade do imposto. Dessa forma, nenhum Estado ou o Distrito Federal poderá passar ao largo desse princípio, como observa ROQUE ANTÔNIO CARRAZA, para quem “não estamos, na hipótese, diante de simples recomendação do legislador constituinte, mas de norma cogente que, por isso mesmo, nem o legislador ordinário nem, muito menos, o interprete, podem desconsiderar, 268 .

Compartilha do mesmo entendimento JOSÉ EDUARDO SOARES DE MELLO, para quem

[...] a inteligência da norma constitucional permite firmar a tranquila diretriz de que o crédito não pode constituir mera faculdade outorgada ao contribuinte, traduzida em um procedimento discricionário. Como o débito deve ser exigido, lançado e liquidado, o mesmo ocorre com o crédito, sem o que o princípio resultaria ineficaz, frustrando-se a dicção constitucional ${ }^{269}$.

\footnotetext{
267 “O princípio da não-cumulatividade dista de ser um valor. É um limite objetivo, mas que se verte, mediatamente, à realização de certos valores, como o da justiça da tributação, o do respeito à capacidade contributiva do administrado, o da uniformidade na distribuição da carga tributária, etc." (CARVALHO, Paulo de Barros. Direito Tributário, linguagem e método. p. 318).

${ }^{268}$ CARRAZA, Roque Antônio.Curso de Direito Constitucional Tributário, p. 401.

${ }^{269}$ MELLO, José Eduardo Soares. ICMS p. 296.
} 


\subsubsection{O princípio da não cumulatividade e o direito aos créditos do ICMS}

O ICMS é um imposto não cumulativo justamente porque, em cada operação ou prestação, o legislador constitucional assegura ao contribuinte uma dedução (abatimento) correspondente aos montantes cobrados nas operações ou prestações anteriores.

Segundo os ensinamentos de GERALDO ATALIBA e CLEBER GIARDINO, citados por ELIUD JOSÉ PINTO DA COSTA ${ }^{270}$, o vocábulo "abatimento" pode ser visto como um processo matemático de dedução no qual, por imposição constitucional, o montante de ICM (hoje ICMS) devido é o minuendo, e o montante de ICM anteriormente cobrado é o subtraendo.

De acordo com PAULO DE BARROS CARVALHO ${ }^{271}$, o ICMS tem por requisito constitucional que sua hipótese tributária traga a descrição do fato de um comerciante, industrial ou produtor praticar operação jurídica que transfira a posse ou propriedade de uma mercadoria. Uma vez ocorrido, no mundo fenomênico, o fato hipoteticamente previsto na regra-matriz do direito ao crédito - no caso, operação relativa à circulação de mercadoria -, nascerá, inexoravelmente, uma relação jurídica que tem como sujeito ativo o adquirente/destinatário de mercadorias, detentor do direito ao crédito do imposto, e como sujeito passivo o Estado.

Tendo participado de operação sobre a qual incidiu o imposto, surge para o adquirente o direito de valer-se de um crédito, cuja configuração dependeu também de ato seu. Se for, em outro momento, integrante da relação jurídica do gravame, na figura de alienante de mercadorias, o contribuinte exercitará seu direito ao crédito mediante a forma juridicamente qualificada da compensação.

Assim, no instante em que se efetivar a operação de compra, estará realizando um negócio jurídico, apurando um crédito tributário, que, somente a partir do momento seguinte (venda), poderá ser confrontado com os débitos para se verificar a existência de saldo credor ou devedor perante o Fisco. Assim, o direito ao crédito é moeda-escritural.

Importante também consignar que o direito ao crédito independe da efetiva cobrança do ICMS nas operações ou prestações anteriores. A expressão empregada pelo legislador constitucional "montante cobrado", contido no artigo $155, \S 2^{\circ}$, inciso I, da Carta

\footnotetext{
${ }^{270}$ COSTA, Eliud José Pinto. ICMS mercantil, p. 61.

${ }^{271}$ CARVALHO, Paulo de Barros. Direito Tributário, linguagem e método. p. 732.
} 
Maior “[...] deve ser juridicamente entendida como 'montante devido' e não como 'montante efetivamente exigido', como ressalta ROQUE ANTÔNIO CARRAZA ${ }^{272}$.

Esse mesmo entendimento é partilhado por PAULO DE BARROS CARVALHO, para quem

[...] com ou sem formalização da obrigação tributária, há o direito ao crédito (e o consequente direito à compensação, pelo primado da não cumulatividade), visto que o nascimento deste decorre de norma jurídica distinta da regra-matriz de incidência do ICMS; decorre da transmissão da titularidade da mercadoria, e não da ocorrência de lançamentos de ICMS que estão alheios ao adquirente ${ }^{273}$.

Feitos esses apontamentos acerca do princípio da não-cumulatividade do ICMS, insta verificar se esse limite objetivo foi observado pelo legislador ordinário estadual, ao exercer a competência para instituição desse imposto na extração do petróleo por meio da Lei $\mathrm{n}^{\circ} 4.117 / 03$.

\subsubsection{Do aproveitamento do crédito de ICMS no Estado de destino se devido o ICMS na extração do petróleo}

Conforme exposto anteriormente, o legislador constituinte criou exceções ao princípio da não cumulatividade, dispondo que as operações isentas ou não sujeitas à incidência desse imposto, prescritas no artigo 155, §2 $2^{\circ}$, inciso II, incisos "a" e "b", do Texto Supremo não gerarão crédito para compensação nas operações subsequentes e culminarão na anulação do crédito na entrada.

$\mathrm{O}$ artigo $155, \S 2^{\circ}$, inciso $\mathrm{X}$, “b”, prescreve, por sua vez, que o ICMS não incidirá sobre "operações que destinem a outros Estados petróleo, inclusive lubrificantes, combustíveis líquidos e gasosos dele derivados, e energia elétrica." Trata-se de uma imunidade objetiva, que "visa a reduzir o custo dos produtos e mercadorias que utilizam esses insumos", como elucida ROQUE ANTÔNIO CARRAZA ${ }^{274}$.

Portanto, nessas operações, o próprio legislador constituinte estabelece que o ICMS incidente sobre a comercialização do petróleo e seus derivados não será devido na origem, mas ao Estado onde estiver localizado o consumidor final.

Por outro lado, é importante salientar que a perda de arrecadação do ICMS pelos Estados produtores que destinam petróleo e derivados para outros Estados da federação é

${ }^{272}$ CARRAZA, Roque Antônio.Curso de Direito Constitucional Tributário, p. 404.

${ }^{273}$ CARVALHO, Paulo de Barros. Op. Cit., p. 733.

${ }^{274}$ CARRAZA, Roque Antônio.Curso de Direito Constitucional Tributário, p. 560. 
suprida pelos recursos provenientes das compensações financeiras, que são devidas aos Estados produtores, como bem ressaltou o Ministro Nelson Jobim no voto proferido no Mandado de Segurança ${ }^{\circ} 24.312^{275}$ : Confira-se:

Em 1988, quando se discutiu a questão do ICMS, o que tínhamos? Houve uma grande discussão na constituinte sobre se o ICMS tinha que ser na origem ou no destino.

A decisão foi que o ICMS tinha de ser na origem, ou seja, os Estados do Sul continuavam gratuitamente tributando as poupanças consumidas nos Estados do Norte e do Nordeste.

Aí surgiu um problema envolvendo dois grandes assuntos: energia elétrica recursos hídricos - e petróleo.

Ocorreu o seguinte: os Estados onde ficasse sediada a produção de petróleo e a produção de energia elétrica acabariam recebendo ICMS incidente sobre o petróleo e a energia elétrica.

O que se fez? Participei disso diretamente, lembro-me que era, na época, o Senador Richard quem defendia os interesses do Estado do Paraná e o Senador Almir Gabriel quem defendia os interesses do Estado do Pará, além do Rio de Janeiro e Sergipe, em relação à plataforma de petróleo.

Então, qual foi o entendimento político naquela época que deu origem a dois dispositivos na Constituição? Daí porque preciso ler o $\S 1^{\circ}$ do art. 20 , em combinação com o inciso X do art. 155, ambos da Constituição Federal.

O que se fez? Estabeleceu-se que o ICMS não incidiria sobre operações que se destinassem a outros Estados - petróleo, inclusive lubrificantes, combustíveis líquidos, gasosos e derivados e energia elétrica -, ou seja, tirou-se da origem a incidência do ICMS.

Vejam bem, toda a produção de petróleo realizada no Estado do Rio de Janeiro, ou toda a produção de energia elétrica, no Paraná e no Pará, eram decorrentes de investimentos na União, porque o monopólio era da União. Toda a arrecadação do País contribuiu para aquela produção.

Assim, decidiu-se da seguinte forma: tira-se o ICMS da origem e se dá aos Estados uma compensação financeira pela perda dessa receita. Aí criou-se o $§ 1^{\circ}$ do art. 20, dizendo:

(...)

Então, Ministra Ellen, estou tentando recompor a questão histórica, com isso, estou entendendo que não é uma receita da União que liberalmente está dando, por convênio, aos Estados, face à compensação financeira da exploração em seu território de um bem, de um produto sobre o qual não incide o ICMS. Essa é a origem do problema. (g.n.)

275 “MANDADO DE SEGURANÇA. ATO CONCRETO. CABIMENTO. EXPLORAÇÃO DE PETRÓLEO, XISTO BETUMINOSO E GÁS NATURAL. PARTICIPAÇÃO, EM SEU RESULTADO, DOS ESTADOS, DISTRITO FEDERAL E MUNICÍPIOS. CONSTITUIÇÃO FEDERAL, ART. 20, $\S 1^{\circ}$. COMPETÊNCIA DO TRIBUNAL DE CONTAS DO ESTADO DO RIO DE JANEIRO PARA A FISCALIZAÇÃO DA APLICAÇÃO DOS RECURSOS ORIUNDOS DESTA EXPLORAÇÃO NO TERRITÓRIO FLUMINENSE. 1 - Não tendo sido atacada lei em tese, mas ato concreto do Tribunal de Contas da União que autoriza a realização de auditorias nos municípios e Estado do Rio de Janeiro, não tem aplicação a Súmula 266 do STF. 2 - Embora os recursos naturais da plataforma continental e os recursos minerais sejam bens da União (CF, art. 20, V e IX), a participação ou compensação aos Estados, Distrito Federal e Municípios no resultado da exploração de petróleo, xisto betuminoso e gás natural são receitas originárias destes últimos entes federativos ( $\mathrm{CF}$, art. $\left.20, \S 1^{\circ}\right) .3$ - É inaplicável, ao caso, o disposto no art. 71, VI da Carta Magna que se refere, especificamente, ao repasse efetuado pela União - mediante convênio, acordo ou ajuste - de recursos originariamente federais. 4 - Entendimento original da Relatora, em sentido contrário, abandonado para participar das razões prevalecentes. 5 - Segurança concedida e, ainda, declarada a inconstitucionalidade do arts. $1^{\circ}$, inc. XI e 198, inc. III, ambos do Regimento Interno do Tribunal de Contas da União, além do art. 25, parte final, do Decreto no 1, de 11 de janeiro de 1991" (MS 24312, Mi. Ellen Gracie, DJ de 19/12/2003). 
Admitindo a competência dos Estados para instituir o ICMS extraído nos seus respectivos territórios ou mesmo nas áreas marítimas, podemos concluir que o recolhimento desse imposto pelo concessionário situado no Estado de origem (no presente caso, o Estado do Rio de Janeiro) não seria aproveitado para fins de compensação com o ICMS devido nas operações subsequentes praticadas pelos adquirentes estabelecidos nos Estados destinatários, em decorrência da imunidade das operações interestaduais com petróleo previstas no $155, \S 2^{\circ}$, inciso X, "b" da Carta Maior.

Assim, a cobrança do ICMS no momento da extração do petróleo pelo Estado de origem desvirtua o tratamento dado pela Constituição Federal à tributação do petróleo nas operações interestaduais, na medida em que esse imposto passará a ser exigido em todas as fases da cadeia econômica, ou seja, tanto na origem como no destino.

Como consequência dessa situação, o imposto passará a ter efeito cumulativo, em razão da impossibilidade de geração de crédito em favor dos estabelecimentos situados nos Estados destinatários para fins de compensação nas operações subsequentes.

A ocorrência dessa situação foi vislumbrada por IVES GANDRA DA SILVA MARTINS ao analisar o Projeto de Lei $n^{\circ} 407 / 2003$, que foi posteriormente convertido na Lei $\mathrm{n}^{\circ} 4.117 / 03$, promulgada pelo Estado do Rio de Janeiro. Naquela ocasião, o Jurista afirmou que

[...] o texto constitucional expressamente declara que o produto nas operações interestaduais, será tributado no destino, enquanto a futura lei pretende criar uma tributação na origem, que não será compensável no destino em nenhum Estado, visto que é hipótese não só não prevista, mas proibida pelo texto constitucional e legislativo. Trata-se de imunidade constitucional, que não pode ser afastada por lei ordinária estadual ${ }^{276}$.

Portanto, temos para nós que o legislador ordinário estadual não observou o princípio limite-objetivo da não cumulatividade do ICMS ao exercitar a competência para a instituição desse imposto na extração do petróleo.

${ }^{276}$ MARTINS, Ives Gandra da Silva. Fato gerador do ICMS nas operações interestaduais com petróleo e derivados. Revista Dialética de Direito Tributário. n. 96. São Paulo: Malheiros, set. 2003. 


\section{CONCLUSÕES}

(i) A norma não se encontra no texto do direito positivo, não está nele impregnado, mas é construída pelo intérprete a partir dele. Portanto, norma é o resultado do trabalho mental do intérprete de construção e estruturação das significações na forma hipotético-condicional. A proposição implicante (hipótese ou antecedente) descreve um evento de possível ocorrência no mundo social. A proposição implicada (consequente ou tese) prescreve uma relação entre dois ou mais sujeitos, modalizada como obrigatória, proibida ou permitida.

(ii) A regra-matriz de incidência tributária é uma norma geral e abstrata, que descreve em seu antecedente uma classe de fatos constituídos de condutas humanas passíveis de ocorrerem no mundo concreto (critério material), os quais devam ocorrer em determinado território (critério espacial), indicando um dado momento em que se possa reputar ocorrido o fato (critério temporal), para que assim se possa deflagrar o consequente, no qual também de forma abstrata prescreve os elementos de uma relação jurídica, indicando os seus sujeitos, ativo e passivo (critério pessoal), bem como os dados necessários para se definir qual será a prestação devida (critério quantitativo).

(iii) Considerando-se que o direito positivo é um corpo de linguagem, que se materializa na forma de um conjunto de enunciados prescritivos, concluímos que o direito provém da "atividade produtora de enunciados", que é denominada enunciação (fonte de direito).

(iv) A enunciação deve seguir a forma prescrita na regra de competência, o que significa dizer que só pode ser realizada pelo sujeito investido para tanto, por meio do veículo introdutor específico (por lei complementar, lei ordinária etc.), no local e no intervalo temporal previstos. Da mesma forma, o produto da enunciação (enunciado) deve respeitar a materialidade descrita na regra de competência, os princípios, as imunidades específicas e os enunciados complementares.

(v) O critério material é um proceder humano, linguisticamente representado por um verbo pessoal de predicação incompleta, que deve estar no infinitivo, e o seu complemento. No que tange ao ICMS mercantil, o seu critério material é "realizar operações relativas à circulação de mercadorias". 
(vi) A operação, a que alude o texto constitucional, é um negócio jurídico mercantil apto a provocar a circulação da mercadoria. A circulação jurídica, que não se confunde com a circulação física ou econômica, ocorre quando há a transferência de titularidade das mercadorias de uma pessoa para outra. Já a mercadoria é o bem móvel destinado à mercancia.

(vii) A extração do petróleo não configura uma operação relativa à circulação de mercadoria, pelos seguintes motivos:

a. a exploração de petróleo por meio do contrato de concessão não se qualifica como operação mercantil, pois esse contrato (i) está submetido ao regime de direito público e não privado, e (ii) tem por objeto uma obrigação de fazer (a União confere ao concessionário apenas o direito de explorar e produzir o petróleo e o gás natural) e não uma obrigação de dar (não se trata de uma compra e venda, mas de um contrato de risco);

b. não há circulação jurídica no momento em que o petróleo é extraído da jazida. Esse instante representa apenas o momento em que esse recurso mineral passa a existir como produto, que ainda não integra o ciclo econômico;

c. o petróleo não se amolda ao conceito de mercadoria, justamente porque se trata de um bem público de uso especial, inalienável por natureza e insuscetível de desafetação por determinação constitucional;

d. $O$ artigo 26 da Lei $\mathrm{n}^{\circ}$ 9.478/97, editada em conformidade com o artigo 176 da Carta Maior, conferiu ao concessionário a propriedade do petróleo e gás natural após a sua extração. Tal dispositivo legal não quebrou o monopólio da União previsto no artigo 177 do Texto Supremo, conforme reconheceu o Supremo Tribunal Federal ao julgar a ADIN n 3.723-9. O termo "conferência" não pode ser interpretado como "transferência" de propriedade, como sustenta o Estado do Rio de Janeiro na ADIN nº 3019, mas aquisição originária de propriedade pelo concessionário, que é garantida pela própria Constituição Federal na parte final do artigo 176, caput.

(viii) Ante essas considerações, concluímos que os enunciados-enunciados veiculados pela Lei $\mathrm{n}^{\circ} 4.117 / 03$, que prescrevem a incidência do ICMS na extração do petróleo, foram produzidos pela autoridade competente (Assembleia Legislativa do Estado do Rio de Janeiro) em desconformidade com a regra de competência para a instituição do ICMS mercantil, na medida em que o legislador infraconstitucional não respeitou a materialidade constitucional desse imposto. 
(ix) A passagem do petróleo pelos pontos de medição de produção não pode ser considerada o critério temporal da hipótese de incidência do ICMS. Esse momento indica apenas o instante em que o petróleo deixa a jazida, de propriedade da União, e se transforma em produto de propriedade do concessionário. Esse momento nem sequer está previsto no artigo $2^{\circ}$ da Lei Complementar $n^{\circ} 87 / 96$, enunciado complementar que delimita a criação do ICMS.

(x) O legislador ordinário estadual elegeu o local onde o petróleo for encontrado como o critério espacial da hipótese de incidência do ICMS. Entretanto, o conceito de jazida não pode ser equiparado ao conceito de estabelecimento, eis que a jazida não é o local onde a União exerce suas atividades mercantis e o petróleo nela encontrado não se qualifica como mercadoria.

(xi) A União, na condição de pessoa jurídica de direito público internacional, exerce soberania sobre o mar territorial, que lhe pertence, conforme prescreve o artigo 20, inciso VI, da Constituição Federal. Não há, assim, espaço para que os Estadosmembros, que possuem apenas autonomia, produzam normas que tenham eficácia sobre fatos ocorridos nessas áreas, sobretudo em matéria tributária.

(xii) O mar territorial integra o território nacional e, portanto, o território dos Estados e dos Municípios. Entretanto, não há lei nacional que especifique que parcela do mar territorial compete a cada Estado estabelecido na costa brasileira, o que seria indispensável para evitar eventuais conflitos de competência entre os Estadosmembros. Além disso, a Lei Complementar $n^{\circ}$ 87/96 não contempla o mar territorial como local em que ocorre operação relativa à circulação de mercadorias.

(xiii) Diversamente do que ocorre com o mar territorial, que pertence à União, apenas os recursos minerais extraídos da zona econômica exclusiva e da plataforma continental são de domínio desse ente federativo, mas não as áreas onde estão estabelecidas, que não integram o território brasileiro. Logo, nenhum Estado da federação possui competência para editar normas sobre tais áreas, razão pela qual as operações mercantis de circulação de mercadorias realizadas nessas áreas marítimas não são alcançadas pelo ICMS.

(xiv) O "preço de referência" tomado pela Lei $n^{\circ} 4.117 / 03$ como base de cálculo do ICMS na hipótese de extração de petróleo se assemelha à sistemática de pauta de valores, na medida em que busca reproduzir o valor médio do preço de venda praticado pelo concessionário em condições de mercado. A pauta de valores não mensura o "valor da operação de que decorra a saída da mercadoria", como 
prescreve o artigo 13, inciso I, da Lei Complementar $n^{\circ} 87 / 96$ e somente pode ser aplicada nas situações excepcionais prescritas no artigo 148 do CTN.

(xv) A Lei Complementar n 87/96 não fixou o "preço de referência" do petróleo como base de cálculo do ICMS na hipótese de venda de mercadorias. Logo, o enunciadoenunciado veiculado pela Lei $\mathrm{n}^{\circ} 4.117 / 03$, que trata sobre o critério espacial do ICMS incidente na extração do petróleo, não foi produzido em conformidade com o referido enunciado complementar.

(xvi) Admitindo que a extração de petróleo pudesse ser qualificada como uma operação relativa à circulação de mercadoria, somente poderia ser sujeito passivo da relação jurídico tributária a União, na condição de "alienante" da "mercadoria" petróleo. Contudo, esse ente federativo não poderia, nessa hipótese, ser eleito como sujeito passivo da obrigação tributária, em razão da imunidade recíproca prescrita no artigo 150, inciso VI, alínea “a”, da Constituição Federal.

(xvii) $\mathrm{O}$ extrator do petróleo não pratica nenhuma operação relativa à circulação de mercadorias quando promove a extração desse bem público, motivo pelo qual não é possível enquadrá-lo como contribuinte do ICMS, como prevê o artigo 15, inciso I, da Lei ${ }^{\circ} 4.117 / 03$.

(xviii) A Lei $\mathrm{n}^{\circ}$ 4.117/03 veiculou uma norma de substituição tributária na medida em que atribuiu a responsabilidade pelo pagamento do ICMS ao concessionário, que seria o adquirente da "mercadoria" e não ao seu "alienante". Tal norma, no entanto, foi produzida sem a observância do enunciado constitucional prescrito no artigo 155, $\S 2^{\circ}$, inciso XII, alínea "b", da Constituição Federal, o qual exige a veiculação de lei complementar para dispor sobre substituição tributária.

(xix) O legislador ordinário estadual não observou o princípio limite-objetivo da não cumulatividade ao criar o ICMS incidente na extração do petróleo, na medida em que a cobrança desse imposto pelo Estado produtor de petróleo não gera crédito ao adquirente situado no Estado de destino para fins de compensação nas operações subsequentes, em decorrência da imunidade das operações interestaduais previstas no artigo $155, \S 2^{\circ}$, inciso X, "b”, da Carta Maior'.

(xx) Em vista de todo o exposto, entendemos que o Estado do Rio de Janeiro não observou os limites materiais (o arquétipo constitucional do ICMS, a Lei Complementar $n^{\circ} 87 / 96$ e o princípio da não-cumulatividade) ao instituir, por meio da Lei 4.117/03, o ICMS na extração do petróleo. 
(xxi) Os Estados e o Distrito Federal não detêm competência para a instituição do ICMS na extração do petróleo, como indevidamente fez o Estado do Rio de Janeiro por meio da Lei $n^{\circ} 4.117 / 03$. 


\section{REFERÊNCIAS BIBLIOGRÁFICAS}

AFONSO, José Roberto Rodrigues; GOBETTI. Sérgio Wuff. Rendas do petróleo no Brasil: alguns aspectos fiscais e federativos. Revista do BNDES, Rio de Janeiro, v. 15. 2008.

ALEXY, Robert. Teoria dos direitos fundamentais. São Paulo: Malheiros, 2008.

ARAGÃO, Alexandre Santos. O contrato de concessão de exploração de petróleo e gás. Revista eletrônica de Direito Administrativo Econômico, n. 5, fev./, mar./ abril 2006.

ATALIBA, Geraldo. Incorporação ao ativo - Empresa que loca, oferece em "leasing" seus produtos - Descabimento do ICMS. Revista de Direito Tributário. São Paulo,v. 52.1990

; GIARDINO, Cleber. Núcleo da definição constitucional do ICM. Revista de Direito Tributário. São Paulo, v. 25-26, 7. ed. 2004.

ÁVILA, Humberto. Teoria dos princípios: da definição à aplicação dos princípios jurídicos. 14ª ed. São Paulo: Malheiros, 2013.

BARRETO, Aires Fernandino. ISS - Não Incidência sobre Atividades desenvolvidas em águas marítimas. Revista Dialética de Direito Tributário. São Paulo, n. 200, maio 2012.

Max Limonad, 1998.

Base de cálculo, alíquota e princípios constitucionais. $2^{\mathrm{a}}$ ed. São Paulo:

BASTOS, Celso Ribeiro; MARTINS, Ives Gandra. Comentários à Constituição do Brasil. São Paulo: Saraiva, 1990. 7 v.

Brasil. São Paulo: Saraiva, 1992. 3 v.

Comentários à Constituição do

Celso Ribeiro. Curso de Direito Constitucional. São Paulo: Celso Bastos Editora, 2002.

BERCOVICI, Gilberto. Direito econômico do petróleo e dos recursos minerais. São Paulo: Quartier Latin, 2011.

BOBBIO, Norberto. Direito e poder. 2a ed. São Paulo: Editora Unesp, 2008.

1999.

Teoria do ordenamento jurídico. 10ª ed. Brasília: Universidade de Brasília,

BRITTO, Lucas Galvão. O lugar e o tributo. Estudo sobre o critério espacial da regramatriz de incidência tributária no exercício da competência tributária para instituir e arrecadar tributos. 2013. 195 f. Dissertação (Mestrado em Direito) - Pontifícia Universidade Católica, São Paulo, 2013. 
BRITO, Raimundo Mendes. Flexibilizar significa desenvolver. In: A nova regulamentação da indústria do petróleo no Brasil. Rio de Janeiro: FGV, 1997.

CARDOSO, Auta Alves. A classificação jurídica das denominadas participações governamentais na indústria de petróleo e gás. 2013. 333 f. Tese (Doutorado em Direito) - Pontifícia Universidade Católica, São Paulo, 2013.

CARRAZA, Roque Antônio. Curso de Direito Constitucional Tributário, $26^{\mathrm{a}}$ ed. São Paulo: Malheiros, 2010.

. ICMS. 16 $6^{\mathrm{a}}$ ed. São Paulo: Malheiros, 2012.

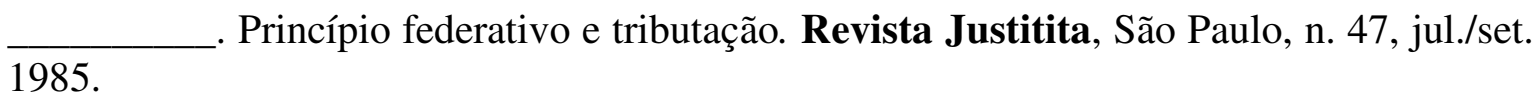
. Natureza jurídica da compensação financeira pela exploração de recursos minerais. Sua manifesta inconstitucionalidade. Revista Justitita, São Paulo n. 57, jul./set. 1995.

CARVAlHO, Aurora Tomazini. Curso de Teoria Geral do Direito. $2^{\mathrm{a}}$ ed. São Paulo: Noeses. 2010.

CARVAlHO, Paulo de Barros. Curso de Direito Tributário. $22^{\mathrm{a}}$ ed. São Paulo: Saraiva, 2011.

. Direito Tributário, linguagem e método. $3^{\mathrm{a}}$ ed. São Paulo: Noeses, 2011.

Paulo: Saraiva, 2010.

Direito Tributário: fundamentos jurídicos da incidência. $8^{\mathrm{a}}$ ed. rev. São O princípio da territorialidade no Direito Tributário. Revista de Direito Tributário, n. 76. São Paulo

Regra Matriz do ICM. Tese apresentada para a obtenção do Título de Livre-Docente da Faculdade de Direito da Pontifícia Universidade Católica, São Paulo, 1981.

COÊLHO, Sacha Calmon Navarro. Royalties do petróleo. A lei é constitucional. Belo Horizonte: Editora Luminus, 2013.

COSTA, Alcides Jorge. Operações com petróleo - Projeto de Lei do Estado do Rio de Janeiro - Fato gerador: extração do petróleo - Extensão territorial da competência tributária. In: Estudos sobre IPI, ICMS, ISS. ICMS. São Paulo: Dialética, 2009.

COSTA, Eliud José Pinto. ICMS Mercantil. São Paulo: Quartier Latin, 2008.

COSTA, Maria D’Assunção. Comentários à Lei do Petróleo: Lei Federal n 9.478, de 68-1997. $2^{a}$ ed. São Paulo: Atlas, 2009. 
DINIZ, Maria Helena. Compêndio de introdução à ciência do Direito. $8^{\mathrm{a}}$ ed. São Paulo: Saraiva, 1995.

FERRAZ JUNIOR, Tercio Sampaio. Introdução ao estudo do Direito: técnica, decisão e dominação. $6^{\text {a }}$ ed. São Paulo: Atlas, 2011.

FERREIRA, Aurélio Buarque de Holanda. Novo Aurélio. $4^{\mathrm{a}}$ ed. São Paulo: Nova Fronteira, 2010.

FIGUEIREDO, Lúcia Valle. Curso de Direito Administrativo. $8^{\text {a }}$ ed. São Paulo: Malheiros, 2006.

FREIRE, Willian. Natureza jurídica do consentimento para pesquisa mineral, do consentimento para lavra e do Manifesto de Mina no Direito Brasileiro. Belo Horizonte: Mineira Livros Jurídicos, 2005.

GAMA, Tácio Lacerda. Competência tributária, fundamentos para uma Teoria da Nulidade. $2^{\text {a }}$ ed. São Paulo: Noeses, 2011.

GASPARINI, Giosenes. Direito Administrativo. $7^{\text {a }}$ ed. São Paulo: Saraiva, 2002.

GIARDINO, Cleber. Territorialidade e ICM. Revista de Direito Mercantil, Industrial, Econômico e Financeiro. São Paulo, v. 43, jul./set. 1981.

GRAU, Eros. A ordem econômica na Constituição de 1988. $15^{\mathrm{a}}$ ed. São Paulo: Malheiros, 2012.

GRECO, Marco Aurélio. ICMS - Exigência em relação à extração do petróleo. Revista Dialética de Direito Tributário, São Paulo n. 100. jan. 2004.

Marco Aurélio. Impossibilidade de cobrar ICMS em operações ocorridas no mar territorial e na zona econômica exclusiva. Revista Dialética de Direito Tributário, São Paulo n. 133. out 2006.

GUTMAN, José. Tributação e outras obrigações na indústria do petróleo. Rio de Janeiro: Freitas Bastos Editora, 2002.

HERNANDEZ, Fernanda Guimaraes. Compensação financeira para exploração de recursos minerais - Regra-Matriz de incidência. Tese (Doutorado em Direito) Universidade de São Paulo, 2013

IVO, Gabriel. Norma jurídica, produção e controle. São Paulo: Editora Noeses, 2006.

JUNIOR, José Cretella. Comentários à Constituição de 1988. Rio de Janeiro: Forense, $1991.3 \mathrm{v}$.

KELSEN, Hans. Teoria pura do Direito. $2^{\mathrm{a}}$ ed. São Paulo: Martins Fontes, 2006.

LINS, Robson Maia. Controle de constitucionalidade da norma tributária. São Paulo: Quartier Latin, 2005. 
MARTINS, Eliane M. Octaviano. Curso de Direito Marítimo. São Paulo: Manole, 2005.

MARTINS, Ives Gandra. Comentários à Constituição do Brasil. $3^{\text {a }}$ ed. São Paulo: Saraiva, 2004.

Fato gerador do ICMS nas operações interestaduais com petróleo e derivados. Revista Dialética de Direito Tributário. São Paulo, n. 96, set. 2003.

MEDAUAR, Odete. Direito Administrativo Moderno. 16 a ed. São Paulo: Revista dos Tribunais, 2012.

MELLO, Celso Antônio Bandeira. Curso de Direito Administrativo. 25a ed. São Paulo: Malheiros, 2008.

MELLO, José Eduardo Soares. ICMS. Teoria e prática. 12ª ed. São Paulo: Dialética, 2012.

MELLO, Oswaldo Aranha Bandeira. Princípios gerais do Direito Administrativo. $3^{\text {a }}$ ed. São Paulo: Malheiros, 2007.

MENDONÇA, Cristiane. Competência tributária. 1a ed. São Paulo: Quartier Latin, 2004.

MEYER, Antônio Correa Meyer; NOVAIS, Raquel. Análise da validade da cobrança de ICMS sobre a extração de petróleo no Estado do Rio de Janeiro: Lei Noel. Revista de Direito Tributário. São Paulo, n. 93, 2006.

MONTEIRO, Washington de Barros. Curso de Direito Civil, Direito das Coisas. $40^{\mathrm{a}}$ ed. São Paulo: Saraiva, 2010.

MORAES, Alexandre. Regime jurídico da concessão para exploração do petróleo e gás natural. Jus Navigandi. Disponível em: <http://jus.com.br/artigos/2426/regime-juridicoda-concessao-para-exploracao-de-petroleo-e-gas-natural>. Acesso em: 13 Jan. 2013.

MOUSSALEM, Tárek Moysés. Fontes do Direito Tributário. São Paulo: Max Limonad, 2001 .

OLIVEIRA, Regis Fernando. Curso de Direito Financeiro. $3^{\text {a }}$ ed. São Paulo: Revista dos Tribunais, 2010.

PIETRO, Maria Sylvia Zanella. Uso privativo de bem público por particular. $2^{\mathrm{a}}$ ed. São Paulo: Atlas, 2010.

Direito Administrativo, São Paulo: Atlas, 1999.

PIRES, Paulo Valois. A evolução do monopólio estatal do petróleo. 1999. Tese (Mestrado) - Universidade de São Paulo, São Paulo, 1999.

SCAFF, Fernando Facury. Aspectos controvertidos da CFEM - Compensação financeira pela exploração de recursos minerais (royalties da mineração). In: Direito Tributário e Econômico aplicado ao meio ambiente e à mineração. São Paulo: Quartier Latin, 2009. 
SILVA, José Afonso. Comentário contextual à Constituição. $5^{\text {a }}$ ed. São Paulo: Malheiros, 2007.

TORRES, Heleno Taveira. A compensação financeira devida pela utilização de recursos hídricos, exploração de recursos minerais ou produção de petróleo, xisto betuminoso e gás natural (art. $20, \S 1^{\circ}, \mathrm{CF}$ ) - Sua natureza jurídica. In: Grandes questões atuais do Direito Tributário. São Paulo: Dialética, 1998. 2 v.

VELOSO, Andrei Piten. Conceitos e competências tributárias. São Paulo: Dialética, 2005.

VENOSA, Silvio de Salvo. Direitos reais. 9a ed. São Paulo: Atlas, 2009.

VILLANOVA, Lourival. O universo das fórmulas lógicas e o Direito. Escritos jurídicos e filosóficos. São Paulo: IBET, 2003. 1 v.

Noeses, 2010.

As estruturas lógicas e o sistema do Direito Positivo. $4^{\text {a }}$ ed. São Paulo:

XAVIER, Alberto. Natureza jurídica e âmbito de incidência da compensação financeira por exploração de recursos minerais. Revista Dialética de Direito Tributário. São Paulo, n. 29 , fev. 1998. 